\title{
VINCULAÇÃO DE RECEITAS PÚBLICAS E PRINCÍPIO DA NÃO AFETAÇÃO: USOS E MITIGAÇÕES
}

\author{
Dissertação apresentada à Faculdade de \\ Direito da Universidade de São Paulo, \\ como exigência para a obtenção do \\ grau de Mestre em Direito Econômico, \\ Financeiro e Tributário. \\ Orientador: Professor Associado José \\ Mauricio Conti
}

UNIVERSIDADE DE SÃO PAULO

Faculdade de Direito

São Paulo 
Banca Examinadora 


\section{AGRADECIMENTOS}

A tarefa de externar os agradecimentos costuma ser tão árdua quanto à da elaboração da própria dissertação. Dessa forma, pode ser que nesta página ocorram algumas omissões injustas, mas isso não significa que a pessoa não tenha sido menos importante para a realização deste trabalho - que vem sendo concebido desde 2008.

Primeiramente, gostaria de agradecer ao Professor José Mauricio Conti por ter depositado sua confiança na concepção deste trabalho, vinda mediante a sua competente orientação e oportunidade que me foi concedida. Tenho muito a agradecer à banca de minha Tese de Láurea no quinto ano da São Francisco e ao meu orientador na época - o Professor Paulo de Barros Carvalho -, ocasião em que tive a oportunidade de conhecer o Professor Mauricio (que compunha a banca) e passar a admirá-lo pelo grande trabalho que vem fazendo na disciplina de direito financeiro.

Além disso, não poderia deixar de agradecer aos outros professores do Departamento de Direito Econômico, Financeiro e Tributário, em especial os Professores Carlos Eduardo Faraco Braga e Fernando Facury Scaff pelas grandes contribuições dadas no desenvolvimento do tema, agradecimento que estendo também ao Professor Sérgio Assoni Filho.

Agradeço aos novos colegas de pós-graduação da São Francisco, bem como aos antigos colegas de graduação e outras amizades cultivadas fora da Academia. Esse convívio, sem dúvidas, serviu para enriquecer, em muito, a minha pesquisa.

Também sou grato pelo apoio dado pelos Drs. Moacyr Servilha Duarte, Carlos Alberto Felizola Freire e Antonio Carlos Vitiello no transcorrer deste curso de Mestrado pelo apoio e compreensão nos momentos de ausência profissional.

E, obviamente, sem o apoio dos familiares, nenhum trabalho é possível. Assim, agradeço especialmente à minha mãe Sonia, meu pai Hélio e minha irmã Mariana por sempre me acompanharem nessa trajetória. Por fim, agradeço à Greice pela compreensão nos períodos de maior dedicação à dissertação: sem sua força esse trabalho provavelmente não existiria. 


\section{RESUMO}

Este trabalho tem como propósito realizar um estudo sobre a vinculação de receitas públicas, com especial atenção para o ordenamento brasileiro. Considera-se o caráter jurídico das vinculações, bem como os prós e contras de sua utilização, cotejando com uma exposição acerca do caráter econômico e político destes institutos. Diante disto, realiza-se uma análise dos critérios temporais, além de sua tipologia e classificação quanto aos efeitos e funções. No ordenamento brasileiro, existem vinculações na sua modalidade stricto sensu ou então na forma de garantia (vinculações-garantia). Há ainda algumas vinculações que são assim chamadas de forma imprópria, como as vinculações para o federalismo fiscal e as despesas mínimas obrigatórias. Após uma análise das vinculações, passa-se para o estudo do princípio da não afetação e sua inter-relação com os princípios da unidade, universalidade e outros também correlatos. A tendência seguida no trabalho é que, apesar das diferenciações entre estes princípios, a sua análise integrativa pode ser proveitosa com o escopo de se atingir os desideratos desejados. Por derradeiro, faz-se uma abordagem dos mecanismos mitigadores das afetações e do princípio da não vinculação de receitas no ordenamento pátrio, sem prescindir da observância aos modelos estrangeiros. Os fundos específicos são os instrumentos mais utilizados no Brasil para se operacionalizar uma vinculação. Porém, com o inchaço da atividade estatal e o consequente aumento das vinculações, verifica-se a criação de um instrumento peculiar a fim de atenuar esta realidade: a Desvinculação das Receitas da União - DRU.

PALAVRAS-CHAVE: vinculação de receitas; vinculação-garantia; princípio da não afetação; fundos; desvinculação de receitas. 


\begin{abstract}
The purpose of this work is to conceive a study on public earmarking, especially in Brazilian law system. The legal characteristic of earmarking and the pros and cons of its usage are considered herein, as well as its comparison to an economical and political overview. Therefore, some statements about temporal criteria are sketched, in addition to their typology and classification as to their effects and the functions. In the Brazilian legal system, few earmarkings are stricto sensu or have the role of guarantees (earmarkingguarantee). There are some improper earmarkings as those so-called "fiscal federalism earmarking" and the mandatory expenditure. After this analysis, it is necessary to outline the non-assignment principle and its relation to unity, comprehensiveness and other equivalent principles. In spite of the differences between these principles, the trend pursued in the work is that a converged approach may be fruitful to reach the desired scopes. Finally, a description on the mechanisms that mitigate the earmarkings and the nonassignment principle in Brazilian law is elaborated, without forgetting the foreign models. Specific funds are the most applied instruments in Brazil under this intention. However, with the swelling of state activity and the consequent earmarked taxes overutilization, the creation of a peculiar tool to extenuate this reality can be verified: the Federal Revenue Unearmarking - FRU.
\end{abstract}

KEYWORDS: earmarking; earmarking-guarantee; non-assignment principle; funds; revenue unearmarking. 


\section{RÉSUMÉ}

Le but de ce travail est de réaliser une étude sur l'affectation des recettes publiques, avec une attention particulière à la réglementation brésilienne. On considère l'angle juridique des affectations, les avantages et les inconvénients de leur utilisation, ainsi qu'une comparaison avec ses caractères économique et politique de ces instituts. Pour cela, il analyse les critères temporels et établit leur typologie et une classification des effets et des fonctions poursuivis. Dans le système juridique brésilien, peu d'affectations sont stricto sensu ou ont un rôle de garantie (affectation-garantie). Certaines affectations sont ainsi faussement nommées, telles que les affectations au fédéralisme fiscal et les dépenses minimales obligatoires. Après l'analyse des affectations, il est nécessaire d'effectuer une étude sur le principe de la non-affectation, sa relation avec les principes d'unité, d'universalité, ainsi que sa connexion à d'autres principes équivalents. En dépit des différences entre ces principes, l'idée poursuivie dans ce travail est que la convergence de ces approches peut être bénéfique aux objectifs escomptés. Enfin, une description du mécanisme qui mitige les affectations et le principe de la non-affectation du système juridique brésilien est élaborée, prenant en compte aussi les modèles étrangers. Les fonds spécifiques sont les instruments utilisés au Brésil pour produire une affectation. Cependant, avec l'augmentation des l'activités du gouvernement et la conséquente surexploitation des affectations, la création d'un outil particulier pour atténuer cette réalité peut être observée: la Désaffectation des Recettes Fédéral - DRU.

MOTS CLÉS: affectation des recettes; affectation-garantie, principe de la non-affectation, fonds, désaffectation des recettes. 


\section{RIASSUNTO}

Questo lavoro ha come proposito uno studio sull'assegnazione del reddito pubblico, con un'attenzione particolare all'ordinamento brasiliano. È stata considerata la natura giuridica delle assegnazioni, così come i pro e i contro del loro uso, confrontando con una mostra sul carattere economico e politico di questi istituti. Visto questo, si è compiuta un'analisi sui criteri temporali e la loro tipologia ed anche una classificazione riguardo agli effetti e le funzioni. In Brasile, ci sono assegnazioni nelle categorie stricto sensu oppure nella forma di garanzia (assegnazioni-garanzia). Ci sono ancora alcune assegnazioni che sono così chiamate impropriamente, come, ad esempio, le assegnazioni per il federalismo fiscale e le spese minime obbligatorie. Dopo un'analisi delle assegnazione, è stato studiato il principio della non-assegnazione e la loro correlazione con i principi della unità, universalità ed anche altri connessi. La tendenza seguita in questo lavoro è che, nonostante le differenze tra questi principi, la sua integrazione nello studio può essere utile con lo scopo di ottenere i oggettivi che si desidera. Per ultimo, è stato fatto un approccio sui meccanismi di mitigazione delle assegnazione e del principio della non-assegnazione nel ordinamento patrio, senza prescindere della osservanza dei modeli stranieri. I fondi specifici sono gli strumenti più utilizzati in Brasile a gestire un'assegnazione. Però con il gonfiore della attività dello Stato ed il conseguente aumento delle assegnazione, vi è la creazione di uno strumento particolare per attenuare questa realtà: la Desassegnazione dei Redditi dell'Unione - DRU.

PAROLE CHIAVI: assegnazione; assegnazione-garantie; principio della nonassegnazione; fondi, desassegnazione dei redditi. 
1. POLISSEMIA DAS VINCULAÇÕES DE RECEITA......................................

1.1. MORFOLOGIA E CARÁTER DAS VINCULAÇÕES: CARÁTER ECONÔMICO ...................4

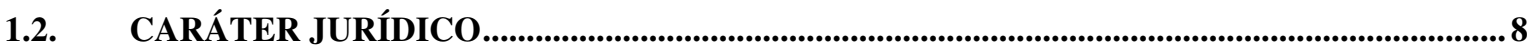

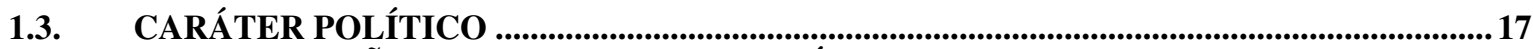

1.3.1. VINCULAÇÃO COMO PROCESSO POLÍTICO …….................................................. 17

1.3.2. EXEMPLO DE VINCULAÇÃO SIMBÓLICO-INSTITUCIONAL DE RECEITAS: O

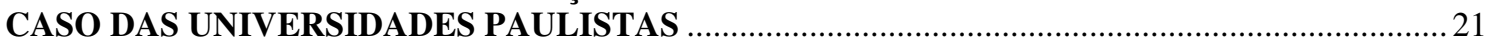

1.3.3. VINCULAÇÃO COMO DOTADORA DE AUTONOMIA FINANCEIRA DOS PODERES 26

1.3.4. SÍNTESE DO CARÁTER POLÍTICO DAS VINCULAÇÕES.

1.4. CRITÉRIOS TEMPORAIS E VINCULAÇÃO A ÓRGÃOS PARAESTATAIS.......................29 1.4.1. VINCULAÇÃO DE RECEITA PARA DOTAR UM SERVIÇO PÚBLICO COM

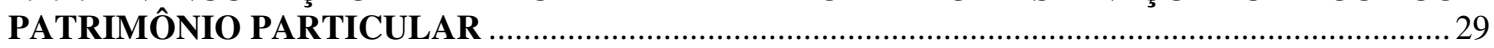

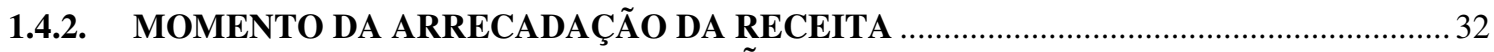

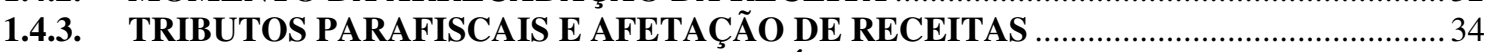

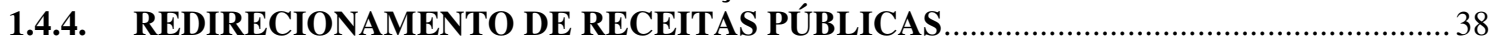

1.5. TIPOLOGIA E CLASSIFICAÇÃO DAS VINCULAÇÕES ...................................................42

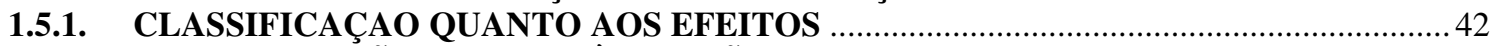

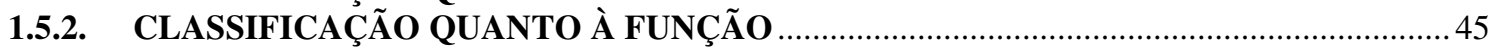

1.6. O TRADE-OFF DA VINCULAÇÃO DE RECEITAS ....................................................51

1.6.1. CRÍTICAS À SUA EXISTÊNCIA: A FALTA DE FLEXIBILIDADE ……………..............53

1.6.2. RAZÕES À SUA EXISTÊNCIA: O MAIOR CONTROLE DOS GASTOS PÚBLICOS....56

1.7. FALSAS AFETAÇÕES DE RECEITAS E ESTIMATIVA DA ARRECADAÇÃo ...................61

2. AS VINCULAÇÕES APLICADAS NO ORDENAMENTO BRASILEIRO ......64

2.1. VINCULAÇÕES DE RECEITAS STRICTO SENSU ……..........................................................64

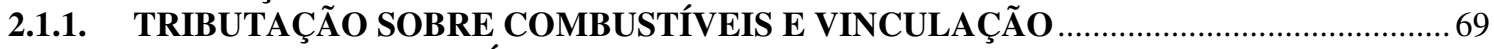

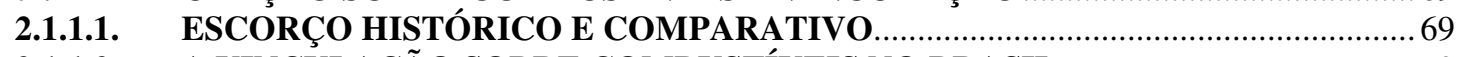

2.1.1.2. A VINCULAÇÃO SOBRE COMBUSTÍVEIS NO BRASIL ……………….................... 72

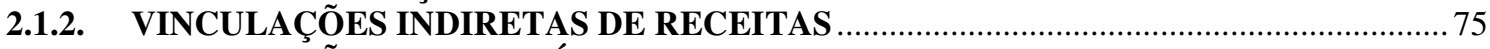

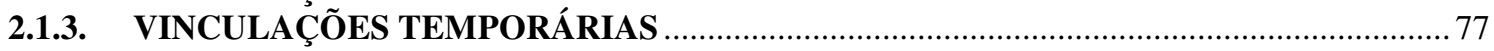

2.2. A "VINCULAÇÃO” DE RECEITAS NO FEDERALISMO FISCAL ......................................80

2.2.1. REPARTIÇÃO DE RECEITAS COMO "VINCULAÇÃO” DE RECURSOS PÚBLICOS 81

2.2.2. DIFERENÇA ENTRE VINCULAÇÕES DE RECEITAS E DESPESAS OBRIGATÓRIAS 83

2.2.2.1. DESPESAS OBRIGATÓRIAS MÍNIMAS PARA A SAÚDE.

2.2.2.2. DESPESAS OBRIGATÓRIAS MÍNIMAS PARA A EDUCAÇÃO …………………......... 89

2.3. VINCULAÇÃO DE RECEITAS PÚBLICAS COMO GARANTIA ..........................................93

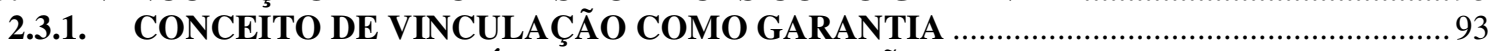

2.3.2. A CREDIBILIDADE PÚBLICA E A VINCULAÇÃO COMO GARANTIA ESPECIAL DO CRÉDITO..

2.3.2.1. A JUSTIFICATIVA DE SEU USO

2.3.3. EVOLUÇÃO DA APLICAÇÃO NO BRASIL 


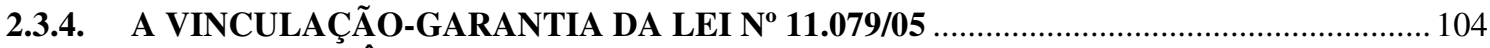

2.3.4.1. IMPORTÂNCIA DO DISPOSITIVO NO ORDENAMENTO …………............................ 104

2.3.4.2. CRÍTICA DOUTRINÁRIA AO DISPOSITIVO …………………………………........ 108

2.3.4.3. INTERPRETAÇÃO PELA CONSTITUCIONALIDADE DO ARTIGO 8º I, DA LEI DAS PPPs 110

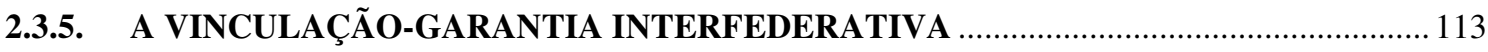

2.3.5.1. REPASSE DE RECURSOS E RECEITAS PARTILHADAS E TRANSFERIDAS ....... 113

2.3.5.2. A RETENÇÃO DA UNIÃO FEDERAL AO REPASSE DE RECURSOS (ART. 167, $\mathbf{4}^{\circ}$, in fine, CF e ART. 40, § $1^{\circ}$, II, LRF)..

2.3.5.3. A VINCULAÇÃO-GARANTIA DE RECEITAS TRANSFERIDAS: O CASO DA LEI BAIANA No 11.477/2009.

3. PRINCÍPIO DA NÃO AFETAÇÃO DE RECEITAS PÚBLICAS 124

3.1. PRINCÍPIOS COM RELAÇÃO ÀS RECEITAS NO DIREITO FINANCEIRO......................124

3.2. ORIGEM E CONTEÚDO DO PRINCÍPIO DA NÃO AFETAÇÃO ..........................................126

3.3. O PRINCÍPIO DA NÃO AFETAÇÃO DE RECEITAS PÚBLICAS NO BRASIL ..................129

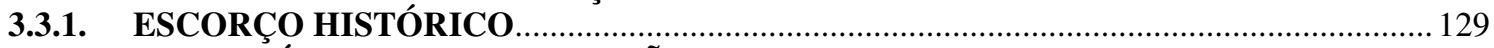

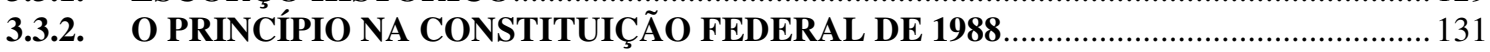

3.4. RAZÕES DA EXISTÊNCIA DO PRINCÍPIO DA NÃO AFETAÇÃO ......................................134

3.5. RELACIONAMENTO DO PRINCÍPIO DA NÃO AFETAÇÃO COM OS PRINCÍPIOS DA

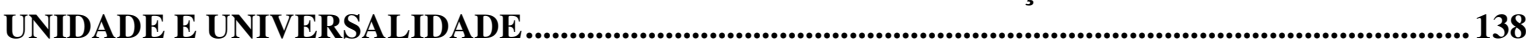

3.5.1. PRINCÍPIO DA UNIDADE ORÇAMENTÁRIA E SEU RELACIONAMENTO COM A

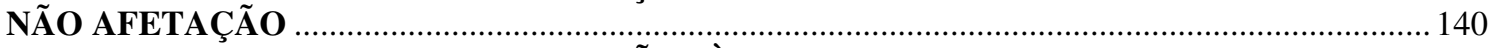

3.5.1.1. FUNDAMENTO E EXCEÇÕES À UNIDADE ................................................... 142

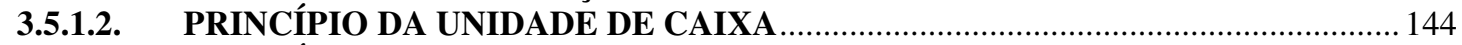

3.5.1.3. PRINCÍPIO DA UNIDADE NO DIREITO COMPARADO ……………………...... 146

3.5.1.4. CONCEPÇÃO MODERNA DO PRINCÍPIO DA UNIDADE ..................................... 149

3.5.2. PRINCÍPIO DA UNIVERSALIDADE ORÇAMENTÁRIA E SEU RELACIONAMENTO

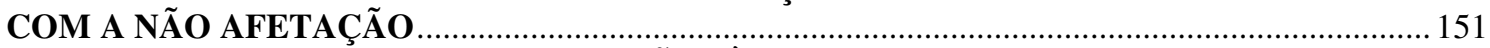

3.5.2.1. FUNDAMENTOS E EXCEÇÕES À UNIVERSALIDADE ………………................... 154

3.5.2.2. PRINCÍPIO DO ORÇAMENTO BRUTO ………………………………………..... 157

3.5.2.3. PRINCÍPIO DA UNIVERSALIDADE NO DIREITO COMPARADO ......................... 158

3.5.2.4. CONCEPÇÃO ATUAL DO PRINCÍPIO DA UNIVERSALIDADE …………….......... 160

3.5.3. CONCEPÇÃO DOUTRINÁRIA INTEGRATIVA DOS PRINCÍPIOS ............................... 162

3.6. PRINCÍPIO DA NÃO VINCULAÇÃO EM OUTROS ORDENAMENTOS JURÍDICOS E

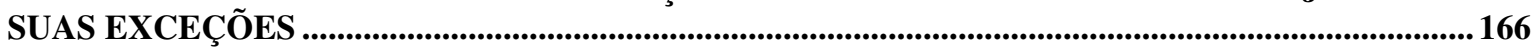

3.7. RELATIVIZAÇÃO DO PRINCÍPIO DA NÃO VINCULAÇÃO DE RECEITAS ....................172

4. MECANISMOS MITIGADORES DA NÃO AFETAÇÃO E DAS VINCULAÇÕES DE RECEITAS NO BRASIL .................................................175

4.1. VINCULAÇÃO DE RECEITAS A FUNDOS ESPECÍFICOS ................................................175

4.1.1. VINCULAÇÃO DE RECEITAS DE RECURSOS NATURAIS A FUNDOS ………........... 178

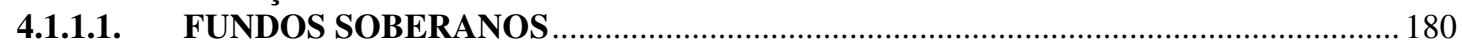

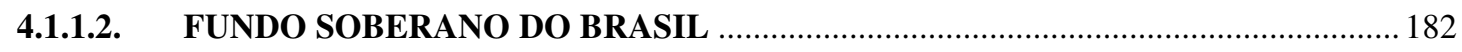

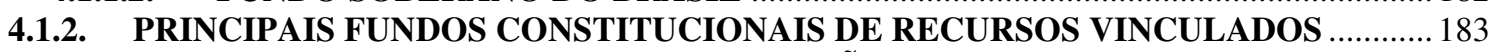

4.1.2.1. FUNDO DE COMBATE E ERRADICAÇÃO DA POBREZA FEDERAL ................. 184

4.1.2.2. FUNDOS DE COMBATE À POBREZA ESTADUAIS, DISTRITAL OU

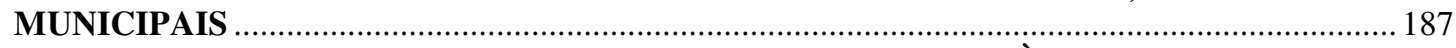

4.1.2.3. FUNDOS ESTADUAIS E DISTRITAL DE FOMENTO À CULTURA ...................... 188 
4.1.2.4. FUNDO DE MANUTENÇAO E DESENVOLVIMENTO DA EDUCAÇÃO BÁSICA E DE VALORIZAÇÃ̃O DOS PROFISSIONAIS DA EDUCAÇÃ̃O - FUNDEB ………………..... 190

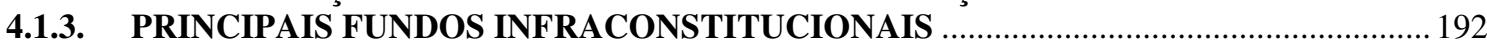

4.1.3.1. FUNDO PENITENCIÁRIO NACIONAL - FUNPEN ……………....................... 192

4.1.3.2. FUNDO ESPECIAL DE ASSISTÊNCIA FINANCEIRA AOS PARTIDOS

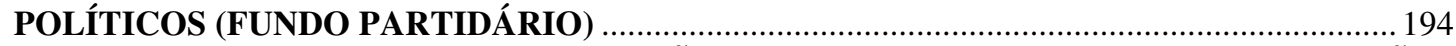

4.1.3.3. FUNDO DE UNIVERSALIZAÇÃO DOS SERVIÇOS DE TELECOMUNICAÇÕES - FUST E FUNDO PARA O DESENVOLVIMENTO TECNOLÓGICO DAS

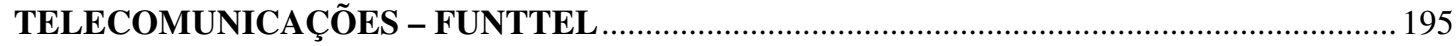

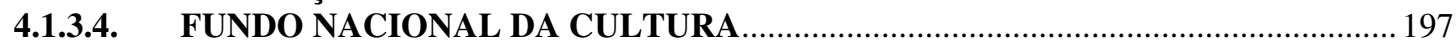

4.1.3.5. FUNDO DA MARINHA MERCANTE - FMM ……………………….................... 198

4.2. DESAFETAÇÃO DE RECEITAS PÚBLICAS ..............................................................199

4.2.1. TENDÊNCIA DESVINCULATÓRIA ESTATAL DAS RECEITAS ……….................. 199

4.2.2. A DESVINCULAÇÃO DE RECEITAS DA UNIÃO - DRU.............................................

4.2.2.1. A POSTERIOR MITIGAÇÃO DA DESVINCULAÇÃO DE RECEITAS DA UNIÃO 207

4.2.2.2. ASPECTOS CONSTITUCIONAIS DA DESVINCULAÇÃO DE RECEITAS DA UNIÃO 209

SÍNTESE CONCLUSIVA ............................................................................214

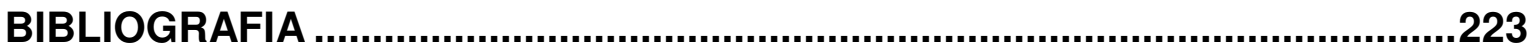

ÍNDICE LEGISLATIVO E OUTRAS FONTES .................................................237 


\section{INTRODUÇÃO*}

A doutrina jurídica financeira é carente de obras monográficas sobre vinculação de receitas e o princípio da não afetação. Comumente, o que se verifica é o tratamento do assunto - não muito aprofundado - em manuais ou outros compêndios, sendo, no entanto, deveras invocado em artigos específicos sobre o tema.

Os estudos internacionais clássicos sempre procuraram delimitar o âmbito de atuação das afetações e do princípio da não vinculação. E, atualmente, a produção científica sobre o tema intenta demonstrar novos horizontes para as vinculações de receitas. Cite-se, por exemplo, o artigo seminal de JACOB WILNER SUNDELSON e os recentes trabalhos de Susannah CAmic, William McCleary e Margaret WiLKinson na doutrina anglo-saxã.

No caso do Brasil, tanto nos manuais sobre o tema como nos artigos científicos, atualmente o termo vinculação vem sendo usado de forma "solta", ou seja, sem muitos critérios científicos do que venha a ser uma afetação. Não há obras que se debrucem exclusivamente sobre as suas características, forma de aplicação, efeitos e outras implicações. Os trabalhos que mais se aproximam desta empreitada na doutrina pátria - ao tentarem delinear a função de uma vinculação de receitas - são dois artigos de FERNANDO FACURY SCAFF, relacionando-a com os direitos humanos de segunda dimensão.

A definição do que é vinculação - separando, obviamente, daquilo que parece uma afetação, mas não é - mostra-se sobremaneira útil para o início da análise do tema. É nesta esteira que o primeiro capítulo tenta analisar as diversas implicações do uso das vinculações de receitas. Será possível perceber que as vinculações, além de seu caráter jurídico, também possuem considerações de ordem econômica e política. Neste último caso, é possível perceber, inclusive, o seu uso no Estado de São Paulo, por meio do que ocorre com o financiamento das universidades paulistas.

Após esta divisão metodológica, outro ponto importante a ser destacado é com relação ao trade-off existente, ou seja, o "dilema" doutrinário quanto ao uso das vinculações: elas serviriam para dar maior solidez nas relações entre Executivo e Legislativo, restringindo, em última instância, a atuação daquele Poder no tocante a certas despesas, tornando-se um eficiente mecanismo de controle. Por outro lado, engessaria a

\footnotetext{
* Todas as citações de autores estrangeiros serão traduzidas de forma livre, com base na nossa compreensão a partir do excerto original. Com relação aos dispositivos legais alienígenas citados, mantivemos na forma original para não haver prejuízo na sua interpretação.
} 
prática orçamentária, diminuindo a sua flexibilidade, além de, em tese, reduzir a eficiência no gasto público. Como sói acontecer na maioria dos trade-offs, é uma questão insolúvel que dependerá do ponto de partida adotado pelo jurista no estudo acerca das vinculações de receitas.

Todavia, não somente estes aspectos devem ser examinados. Sob a análise do caráter jurídico do instituto, é possível observar diversas funções que circundam as vinculações de receitas. É a partir daí que se delineia o segundo capítulo, cingindo-se o âmbito de estudo ao ordenamento brasileiro. Aqui, há aquelas vinculações que seguem o conceito propriamente dito de afetação e as utilizadas como forma de garantia. Observa-se também, por meio da terminologia constitucional adotada, que as repartições de receitas para o federalismo fiscal e as despesas mínimas obrigatórias são impropriamente usadas como sinônimos de vinculação. Com relação a este ponto, a doutrina pátria tende a também considerá-las no âmbito conceitual das afetações de receitas; entretanto, por meio de uma exposição com relação à terminologia adotada, procura-se evitar essa confusão conceitual.

No tocante ao uso das vinculações como garantia, recentemente, com o advento da Lei de Responsabilidade Fiscal - LRF e a Lei das Parceiras Público-Privadas - PPP, as discussões sobre a sua constitucionalidade foram reacendidas. Primeiramente com a LRF, por ter ampliado o conceito de vinculação, introduzindo a possibilidade de retenção para o pagamento de débitos nas vinculações-garantia interfederativas. Após, com o advento da Lei das PPPs, a questão do desrespeito à ordem cronológica dos precatórios por meio da vinculação-garantia também é levantada como inconstitucional. Sob nosso juízo, ver-se-á que, a despeito de no primeiro caso a doutrina apontar pertinentemente a indevida ampliação do termo vinculação, na segunda hipótese a vinculação-garantia pode ter uma interpretação que conduza à sua constitucionalidade.

Delineado o significado de afetação e sua aplicação no Brasil, faz-se mister analisar o postulado que veda a sua aplicação em alguns sistemas jurídicos, o que é feito no terceiro capítulo. No direito pátrio, o princípio da não afetação tem sido inscrito nas últimas Constituições, tendo, em 1988, ocorrido a restrição somente a impostos - com algumas exceções. Já em ordenamentos alheios, ou o princípio aparece implícito, ou deduzido a partir de outros princípios.

Desta forma, a análise do princípio da não vinculação costuma ser mais frutífera quando cotejada com os princípios da unidade e universalidade, em uma concepção integrativa dos princípios. É nesse sentido que a doutrina mais recente vem se inclinando: 
ao invés de se preocupar exclusivamente com a separação entre eles, a identificação dos pontos em comum costuma ser um aspecto relevante.

Com o estudo do que vem a ser vinculação, bem como da regra que a proíbe, o último capítulo tem a função de concluir o trabalho ao introduzir os mecanismos que mitigam a aplicação da vinculação e do princípio da não vinculação no Brasil. Os fundos orçamentários são considerados como uma das formas de se instrumentalizar as vinculações, derrogando o princípio da não afetação em algumas situações.

Porém, no Brasil, ao invés de se promover a extinção de algumas vinculações como forma de se conceder maior flexibilidade ao direito orçamentário, a dificuldade política nestas supressões fez erigir uma modalidade peculiar e até então não verificada em outros ordenamentos. Neste contexto surgiu a Desvinculação de Receitas da União - DRU, vista por alguns doutrinadores como um início de solução para a rigidez do sistema orçamentário brasileiro, mas por outros como uma ferramenta inconstitucional, considerando que se prestaria a desvincular parcela destinada aos direitos prestacionais.

Em vista do exposto, longe de se deter a um foco único de debate, este trabalho visa metodologicamente a analisar com mais afinco alguns dos diversos assuntos relacionados com a vinculação e o princípio da não vinculação de receitas que se situam de forma dispersa na doutrina jurídica pátria. Visa-se, destarte, a definir o que vem a ser vinculação de receitas em cada um de seus contextos para um uso mais criterioso do instituto. 


\section{POLISSEMIA DAS VINCULAÇÕES DE RECEITA}

\subsection{MORFOLOGIA E CARÁTER DAS VINCULAÇÕES: CARÁTER ECONÔMICO}

Etimologicamente, os vocábulos vinculação e afetação trazem, em seus significados, alguns aspectos relevantes quanto à sua delimitação conceitual. Vinculação advém do latim vinculu, cujo significado é liame, laço, ligação. No sentido jurídico, exprime a relação, laço, ligação, elo, união, aliança, comunicação, comunhão, cadeia, dependência, subordinação, conexão existentes entre duas ou mais coisas ou pessoas, tornando-as relacionadas, dependentes, unidas, conexas ${ }^{1}$. O filólogo AURÉLIO BUARQUE DE HOLANDA FERREIRA ${ }^{2}$ também adiciona significados proeminentes a serem considerados no plano desta pesquisa, considerando vínculo como gravame, ônus, restrições, relação, subordinação, nexo, sentido.

Na seara financeira, afetação - do latim affectatione - determina o fim a que ele se destinará ou, então, para o qual será utilizado ${ }^{3}$, cuja obrigatoriedade gera reflexos na satisfação da despesa objeto da vinculação ${ }^{4}$. As expressões consignação e gravação também costumam ser utilizadas doutrinariamente como sinônimas. Há, ainda, a expressão receitas carimbadas - que podem designar a vinculação de receitas tributárias. Especialização, discriminação, especialidade ou especificação - apesar de mencionadas

\footnotetext{
${ }^{1}$ Cf. De Plácido e Silva, Oscar José. Vocabulário Jurídico. 15. ed. Revista e atualizada por SLAIBI FILHO, Nagib; Alves, Geraldo Magela. Rio de Janeiro: Forense, 1998, p. 866-67 e HouAISS, Antonio; VILLAR, Mauro de Salles. Dicionário Houaiss da Língua Portuguesa. Rio de Janeiro: Objetiva, 2001, p. 2863. Frisase, neste compêndio vernacular, que vincular consiste em submeter algo a um domínio, sujeitar, obrigar.

${ }^{2}$ Novo Dicionário da Língua Portuguesa. 2. Ed. Rio de Janeiro: Nova Fronteira, 1986, p. 1777.

${ }^{3}$ Cf. De Plácido e Silva, Oscar José. Vocabulário..., p. 43.

${ }^{4}$ Cf. OliveIrA, Austen da Silva. Aspectos constitucionais e legais do orçamento público. Dissertação (Mestrado em Direito) - Faculdade de Direito, Universidade de São Paulo, 1979, p. 78.
} 
por parcela da doutrina estrangeira ${ }^{5}$ - referem-se a princípio orçamentário de conteúdo diverso, implicando a apresentação das receitas e despesas em detalhe ao invés de em bloco $^{6}$. Isto faz com que o uso das expressões como sinônimas de vinculação reste prejudicado no âmbito da doutrina pátria, razão pela qual preferimos não as utilizar.

A expressão contração, suscitada por ELPIDIO FIGUEIRÊDO ${ }^{7}$, também não será utilizada neste estudo por não ser a forma consagrada na doutrina financista, cabendo apenas o registro deste vocábulo. Sob este conceito, RAYMOND MUZELLEC ${ }^{8}$ define que a regra da não contração significa que não pode haver compensação entre receitas e despesas, devendo haver a inscrição pelo produto bruto no orçamento. A razão de tal cânon seria para evitar a técnica do orçamento líquido, donde se poderia omitir parte de uma receita e toda a despesa correspondente. Inserir contração no conceito de vinculação seria um enquadramento forçado, visto que, sob o nosso juízo, aproximar-se-ia do princípio da universalidade e do orçamento bruto, que serão tratados amiúde oportunamente ${ }^{9}$.

DIETER BÖS ${ }^{10}$ ensina que vinculação, estritamente na sua função econômica, é a correspondência financeira da receita com um determinado custo. Porém, na prática, o que pode ocorrer é que a arrecadação vinculada seja inferior às despesas, o que exigirá, por vezes, a sua complementação pelo orçamento geral. Desta forma, convencionalmente se entende que ocorre a vinculação quando há a completa correspondência com os gastos.

\footnotetext{
${ }^{5}$ Cf. Baudhuin, Fernand. Précis de finances publiques. 4. ed. Bruxelles: E. Bruylant, 1966-68, p. 44. O autor ressalva que não se deve confundir a spécialité com a spécialisation das receitas. O primeiro identificar-se-ia com o princípio da especialização pátrio, e, caso fosse traduzido literalmente, significaria especialidade. Já o segundo - cuja tradução é especialização - consiste na vinculação de receitas. RENÉ STOURM (Le budget: son histoire et son mécanisme. Paris: Guillaumin, 1889, p. 151), ao conceituar a especialização, explica que "consiste em atribuir a cada serviço uma personalidade distinta, retirando da massa as receitas e as despesas que lhes são próprias, a fim de aproximá-las e equilibrá-las." LEÓN SAY (Dictionnaire des finances. Paris: Berger-Levrault et Cie, 1889, p. 611) também faz esta diferenciação, entendendo que o orçamento é a primeira especialização existente na sistemática orçamentária. O ex-ministro de finanças francês explica que em seu país, antes de 1789, havia um completo desconhecimento acerca das despesas e receitas estatais, sendo este assunto relegado apenas ao domínio real e não trazido a lume por razões eminentemente estratégicas. A despeito destas considerações, ocorre que a doutrina pátria, como, v.g., James Giacomoni (Orçamento público. 14. ed. São Paulo: Atlas, 2007, p. 78), entende que o princípio da especialização "é mais uma das regras clássicas dispostas com a finalidade de apoiar o trabalho fiscalizador dos parlamentos sobre as finanças executivas. De acordo com esse princípio, as receitas e as despesas devem aparecer no orçamento de maneira discriminada, de tal forma que se possa saber, pormenorizadamente, a origem dos recursos e sua aplicação."

${ }^{6}$ Cf. Silva, Sebastião de Sant'Anna e. Os princípios orçamentários. Rio de Janeiro: Fundação Getúlio Vargas, Serviço de Publicações, 1962, p. 40.

${ }^{7}$ Principios elementares da sciencia das finanças. Recife: Diário de Pernambuco, 1909, p. 38: “O methodo das contracções tem por effeito applicar uma certa e determinada receita em uma certa e determinada despesa, isto é, fazer recahir directamente os dispendios de percepção sobre o producto do imposto."

${ }^{8}$ Notions essentielles de finances publiques: concours administratifs catégorie A, C.P.A.G.-I.R.A. Paris: Sirey, 1976, p. 155.

${ }^{9}$ Ver item 3.5.2 infra.

${ }^{10}$ Earmarked taxation: welfare versus political support. Journal of Public Economics. v. 75. 2000, p. 443-44 e 459 .
} 
Todavia, o que se observa é que há também casos de arrecadação inferior ou superior aos gastos. E, neste contexto, é importante verificar que, à primeira vista, pode parecer que as vinculações possuem correlação com alguns dos efeitos do princípio do benefício ${ }^{11}$ na tributação. Contudo, é ressalvado que:

O benefício da tributação pode existir independente das vinculações, e vice-versa: tributos que obedecem ao princípio do benefício podem ser alocados em um pool central; por outro lado, ou as receitas podem ser vinculadas para atividades que nada agregam aos contribuintes ${ }^{12}$.

Este enquadramento, portanto, não é acolhido pela doutrina. DIETER Bös ${ }^{13}$, complementando, ressalta que a vinculação não pode servir como (i) razão para um determinado tributo, (ii) facilitador de sua aceitação ou (iii) demonstrador do benefício que o contribuinte auferirá, tendo em vista que, em se tratando - na expressão do autor - de contribuintes racionais, a correlação entre a receita dos tributos em geral e os serviços prestados pelo Estado também é passível de verificação. Isto colidiria com a regra de que os tributos vinculados teriam esta estrita finalidade.

Desta forma, a vinculação de receitas não se confundiria com o princípio usuáriotarifa (user-fee principle) - como ocorre nas taxas, tarifas e contribuições de melhoria. Ademais, a opinião do autor quanto às vinculações abarca a existência de um liame entre tributo específico e uma despesa também específica, não possuindo relação com a carga tributária individual ou com o benefício diretamente auferido pelo contribuinte. Diante disto, vinculação, para o autor, seria um conceito circunscrito ao âmbito do tributo, não comportando o conjunto da receita total ${ }^{14}$.

DAVID DUFF $^{15}$, ao tratar do Canadá, discorre que a prática neste país é de que o produto da arrecadação seja destinado a um fundo geral, sem afetações. Para tributos mais genéricos, o autor entende apropriada tal técnica, rechaçando, no entanto, a aplicação em

\footnotetext{
${ }^{11}$ Cf. Mendes, Marcos. Federalismo fiscal. In: ARvate, Paulo Roberto; Biderman, Ciro (org.). Economia do setor público no Brasil. Rio de Janeiro: Elsevier, 2004, p. 432. Este instrumento tem a vantagem de vincular expressamente o custo (tributo) ao benefício fruído diretamente pelo indivíduo. Eis, então, que “(...) cada indivíduo deveria contribuir com uma quantia proporcional aos benefícios gerados pelo consumo do bem público." (Cf. Giambiagi, Fabio; AlÉm, Ana Cláudia. Finanças públicas. 3. ed. Rio de Janeiro: Elsevier, 2008, p. 18).

${ }^{12}$ Cf. MCCLEARY, William. The earmarking of government revenue: a review of some World Bank Experience. The World Bank Research Observer. v. 6. n. 1. jan. 1991, p. 82.

${ }^{13}$ Earmarked..., p. 460.

${ }^{14}$ Cf. Bös, Dieter. Earmarked..., p. 440, nt. 2. Como exemplo, o autor cita um imposto sobre o champagne alemão instituído em 1902, visto que o Reich desejava expandir a frota alemã. Porém, não se tratava de vinculação, dada a ausência de vinculação explícita para o caso.

${ }^{15}$ Benefit Taxes and User Fees in Theory and Practice. The University of Toronto Law Journal. v. 54. 2004, p. 418-19.
} 
tributos na modalidade de tarifa (como taxa ou preço público) ou tributos onde o beneficiário seja facilmente identificável com o contribuinte $\left(\right.$ gasolina $\left.^{16}\right)$. Somente com a vinculação nestes tributos é que se pode mensurar a quantidade de prestação de serviço que os contribuintes desejam receber e pagar, além de facilitar uma racionalidade nas decisões e garantir equivalência fiscal entre exação e benefícios hauridos dos serviços públicos prestados.

Com base nestes posicionamentos, é possível chegar-se a diversas variações nas vinculações apontadas pela doutrina, quando envolve substancialmente um tributo ou receita ${ }^{17}$ :

a) tributo específico a uso específico: imposto sobre a gasolina para investimentos rodoviários. Ou seja, é a exata correlação entre um tributo e uma despesa destacada;

b) tributo específico para uso amplo: imposto sobre os rendimentos das loterias ou outras sin taxes (como sobre álcool e tabaco) para financiar gastos com saúde, ou tributos sobre petróleo para promover o desenvolvimento nacional. Significa o uso dos recursos de um tributo para um tipo de programa, não necessariamente um gasto específico e relacionado com o tributo;

c) receita total para uso específico: percentual das receitas totais do Estado destinados a uma área, como educação ou saúde. Aqui se considera o produto da arrecadação para uma despesa específica;

d) receita total para um uso geral: repartição das receitas tributárias entre os diversos entes federativos. O produto da arrecadação é, portanto, usado na divisão aos entes beneficiados.

WILLIAM MCCLEARY ${ }^{18}$, na classificação exposta, utiliza a expressão general tax, que pode significar os impostos (tributação para custear as despesas gerais estatais). Em adaptação, usamos a expressão "receita total" para restar evidente a diferença entre vincular tributo e afetar receita tributária. Considera também que as consignações do tipo "a" seriam mais fortes que as demais, fato este que será relevante na análise posterior dos

\footnotetext{
${ }^{16}$ Cf. Bös, Dieter. Earmarked..., p. 428.

${ }^{17}$ Cf. MCClEARY, William. The earmarking..., p. 83, tabela 1 (adaptada).

${ }^{18}$ The earmarking..., p. 82-83.
} 
efeitos da vinculação 19 . Ver-se-á, posteriormente, que as práticas expostas em "c" e "d" não seriam tecnicamente uma afetação, mas o seu uso em uma forma imprópria ${ }^{20}$.

\subsection{CARÁTER JURÍDICO}

Com a evolução do estudo das vinculações, é possível verificar diversos critérios para a formação da sua concepção jurídica. Intentar-se-á delimitar os mais importantes a seguir, de forma dissociada às considerações econômicas ou políticas das vinculações. $\mathrm{Na}$ análise do caráter jurídico, são observadas somente as características que fazem da vinculação de receitas um mecanismo legal utilizado no sistema tributário e orçamentário.

Os instrumentos das vinculações - isto é, como elas normalmente se materializam -, serão tratados com maior detença oportunamente ${ }^{21}$. No Brasil, a principal ferramenta são os fundos; em outros países, contas especiais ou orçamentos anexos costumam ser utilizados.

a) individualização de fontes e destinação

A vinculação das receitas é costumeiramente delineada pela doutrina francesa, dado que, com a Revolução de 1789, diversos princípios orçamentários surgiram naquele período, tal como o da não afetação. Porém, tal prática também é verificada em países de origem anglo-saxã, apesar de haver certa resistência doutrinária em se tratar do orçamento sob este enfoque teórico ${ }^{22}$.

Na Europa, o exemplo paradigmático de vinculação citado pela doutrina ocorreu na dotação orçamentária ao Ministério da Marinha em favor de um monumento em homenagem ao antigo ministro Chasseloup-Laubat, vinculando a receita da venda de cediços canhões e correntes de bronze para angariar as fontes para o custeio dessa obra ${ }^{23}$. Já nos Estados Unidos, demonstra THEDA SKOCPOL ${ }^{24}$ a imensa popularidade das vinculações para programas sociais, advinda, sobretudo, dos programas de pensão no

\footnotetext{
${ }^{19}$ Ver item 1.5.1 infra.

${ }^{20}$ Ver item 2.2 infra.

${ }^{21}$ Ver item 4.1 infra.

${ }^{22}$ Cf. Sundelson, Jacob Wilner. Budgetary principles. Political Science Quarterly. v. 50. n. 2. jun. 1935, p. 236.

${ }^{23}$ Cf. Trotabas, Louis; CotTERet, Jean-Marie. Droit budgétaire et comptabilité publique. 5. ed. avec la collaboration de LAFLANDRE, Michel. Paris: Dalloz , 1995, p. 60.

${ }^{24}$ Apud CAMIC, Susannah. Earmarking: the potential benefits. Pittsburgh Tax Review. v. 4. 2006, p. 56.
} 
período pós-Guerra Civil, cujos tributos cobrados eram associados, pelos contribuintes, a este desiderato social.

$\mathrm{Na}$ Inglaterra, tal prática começou a ser coibida a partir do século XVIII com a criação do Tesouro: sanava-se o problema de vinculação de receitas para determinados serviços em detrimento de outros, fomentando a eficiência e racionalidade da gestão da máquina administrativa. Desta forma, o caixa central público ${ }^{25}$ - formado pelo Tesouro facilitaria a fiscalização da utilização do dinheiro público ${ }^{26}$.

Feito este histórico, é necessário destacar o entendimento de que as receitas oriundas das afetações devem ser distinguíveis das demais. Há diversas modalidades de se individualizar uma receita, como por meio de orçamentos anexos, contas especiais ou fundos. Com a individualização da fonte de custeio com relação às demais receitas orçamentárias, passa-se para a definição da destinação que irá compor a vinculação. $\mathrm{O}$ doutrinador argentino HORACIO GUILLERMO CORTI $^{27}$ assim define a existência de uma afetação:

(...) quando o produto de um instituto arrecadatório em particular se consigne a atender a um gasto ou tipo de gasto, também em particular. A afetação específica implica, por um lado, um desmembramento do fundo do tesouro e a formação de uma conta separada ou 'fundo' especial, ainda quando não se designe de certa forma e, por outro, o financiamento particularizado de um gasto. (destacou-se)

MARGARET WILKINSON ${ }^{28}$ e WiLliAM MCCLEARY $^{29}$ também relatam que a vinculação pode se dar tanto com relação a um tributo específico como com uma receita geral ou pool de receitas (fonte) para um serviço específico ou uma área de atividade (destinação), conforme anteriormente delineado ${ }^{30}$. Logo, pode haver a vinculação (i) do total de uma receita ou tributo - por exemplo, $100 \%$ da receita de impostos ou de um imposto em específico, ou (ii) parcial, i. e., um percentual predeterminado de uma fonte é definido.

\footnotetext{
${ }^{25}$ Com relação ao caixa público, consoante ALAIN BARRÈRE (Politique financière. Paris: Librairie Dalloz, 1958, p. 348-49) é possível extrair sua concepção a contrario sensu do conceito de caixa privado. Advém, em verdade, (i) diretamente da ideia de Tesouro, ou seja, da regulação do tempo e espaço da movimentação dos fundos e (ii) da função de guardar e gerir o dinheiro público. Demonstra também José MARTINHO SiMÕES (Finanças. Coimbra: Neves, 1920, p. 649) que esta é uma conquista relativamente recente no Direito Financeiro.

${ }^{26}$ Cf. Sousa Franco, Antonio Luciano de. Manual de finanças públicas e direito financeiro. v. I. Lisboa: S. N., 1974, p. 671-72.

${ }^{27}$ Derecho constitucional presupuestario. Buenos Aires: Lexis Nexis Argentina, 2007, p. 312.

${ }^{28}$ Paying for public spending: is there a role for earmarked taxes? Fiscal Studies. v. 15. n. 5. nov. 1994, p. 119.

${ }^{29}$ The earmarking..., p. 82.

${ }^{30}$ Ver item 1.1 supra.
} 
Diante disto, entendemos que a distinção é o caráter que qualifica uma receita juridicamente como vinculada, bem como a despesa. Esta distinção, portanto, compreende a formação de um elo normativo - não por meio de Leis Orçamentárias, conforme se verá em seguida ${ }^{31}$ - entre a fonte e a destinação, ou, mais especificamente, entre receita e despesa.

\section{b) predeterminação de escopos}

Característica importante nas vinculações é que o escopo governamental seja predeterminado, uma vez que o "governo tem um propósito previsto para a receita tributária no momento de sua coleta" ${ }^{" 32}$. Desta forma, não é possível a vinculação para despesas inespecíficas - o que não é sinônimo de despesas futuras, pois nada impede o estabelecimento de um tributo vinculado a despesas de uma guerra que está por ser deflagrada. O que não pode haver, por exemplo, é uma vinculação a priori cuja despesa a ser coberta será definida na sobrevinda de uma norma específica, já que a tributação não funciona como um fim em si mesmo.

Este fator permite, por exemplo, uma das vantagens apontadas pela doutrina nas vinculações: fornecer informação sobre o propósito das receitas vinculadas. Desta forma, os contribuintes poderiam chegar a conclusões positivas ou negativas com relação às despesas e o fardo tributário imposto a eles. Ademais, como os políticos em tese deteriam maiores informações sobre os tributos vinculados do que com relação aos não vinculados, estariam mais preocupados com a opinião pública e com a sobrevivência destas exações ao longo do tempo ${ }^{33}$.

Com base nestas duas premissas, SUSANNAH CAMIC ${ }^{34}$ resume:

Para determinar uma definição de um tributo vinculado, este deve ter um propósito predeterminado na coleta, mas não necessita de quaisquer requisitos posteriores, deixando aos governantes múltiplas opções ao traçarem as políticas.

Também não é despiciendo destacar que a predeterminação de despesas ou de algum escopo deve se dar por instrumento normativo que não seja a própria lei orçamentária (empregada aqui em sentido lato, englobando, no País, o plano plurianual, a lei de diretrizes orçamentárias e a lei orçamentária anual), pois caso contrário seria mera especialização das receitas, e não vinculação propriamente dita. A especialização pela lei

\footnotetext{
${ }^{31}$ Ver item "d" infra.

${ }^{32}$ Cf. CAMIC, Susannah. Earmarking..., p. 56.

${ }^{33}$ Cf. CAMIC, Susannah. Earmarking..., p. 58-59.

${ }^{34}$ Earmarking...,p. 60.
} 
orçamentária é o mecanismo que permite a previsão das receitas e cobertura dos respectivos gastos. Já as afetações correriam "fora da lei orçamentária", visto que "não há afetação só à conta do orçamento ou através deste. ${ }^{35}$.

Outro ponto que convém afirmar é que a vinculação não obriga à realização imediata da despesa. O que ela veda, portanto, é a tredestinação de sua finalidade, ou seja, aplicação em outros objetivos que não aqueles predeterminados quando da sua instituição. Tal ponto será mais bem desenvolvido posteriormente para dissociá-la da ideia de despesa obrigatória $^{36}$.

Por fim, merece ressalva que diversos podem ser estes escopos do legislador. Em regra, são despesas predeterminadas, órgãos, ou fundos, conforme prescreve, v. g., o ordenamento pátrio no artigo 167, IV, da Constituição Federal.

\section{c) margem relativa de abolição}

A vinculação de receitas, assim como os próprios tributos, pode ser considerada, pelo Poder Legislativo, como algo prescindível em determinado momento político, social ou econômico. A própria temporariedade de uma cobrança tributária é utilizada como justificativa para se vincular, ou não, determinada receita. A doutrina costuma considerar como melhor tributo a ser vinculado os mais perenes e imutáveis, dado que aqueles com características mais temporárias ou maleáveis prejudicariam a prática vinculatória. Porém, paradoxalmente, a vinculação pode ser um fator determinante para a perenidade desta exação ${ }^{37}$.

Percebe-se, portanto, que a existência das vinculações e dos tributos pode, por vezes, depender da ocorrência de uma ligação entre si. E a extinção de um tributo vinculado deveria comportar, por conseguinte, a supressão da própria vinculação. A questão controvertida que resta definir é com relação a esta possibilidade de abolição.

Vale recordar que as vinculações - ou sua proibição expressa - não são postulados absolutos no ordenamento jurídico. O Parlamento pode deliberar sobre uma vinculação de receitas sempre que possível, salvo se ela própria se constituir em cláusula pétrea e assim for registrada pela Constituição de um Estado. Neste caso, não haverá margem absoluta de abolição das vinculações no ordenamento jurídico.

\footnotetext{
${ }^{35}$ Cf. Oliveira, Austen da Silva. Aspectos..., p. 78.

${ }^{36}$ Ver item 2.2.2 infra.

${ }^{37}$ Cf. FenNel, Lee Anne. Death, taxes, and cognition. North Carolina Law Review. v. 81. 2003, p. 641 e nt. 267, com base nos estudos de BARRY BRACEWELL-MILNES.
} 
Desta forma, tirante a ressalva acima, nada impede que o Legislativo desvincule as rendas da tributação sobre combustíveis para a conservação rodoviária e as utilize no custeio da merenda escolar ${ }^{38}$, por exemplo, desde que o faça seguindo a hierarquia das normas jurídicas e não fira eventual cláusula pétrea estabelecida, conforme nossa opinião destacada. A única questão é quanto ao reflexo político desta decisão, visto que a retirada de uma vinculação do ordenamento nem sempre é vista com bons olhos pelos cidadãoscontribuintes, principalmente por aqueles que se beneficiam mais diretamente dela ${ }^{39}$.

Outro ponto relevante concerne ao princípio da não afetação. Malgrado este princípio poder ser previsto constitucionalmente, entendemos que não há óbices para que, via poder constituinte derivado, haja a sua supressão total, permitindo-se a plena vinculação de receitas por instrumentos normativos infraconstitucionais ${ }^{40}$. Do mesmo modo, não existem encalhes constitucionais para que haja a vedação constitucional explícita da vinculação de quaisquer tipos de receitas - ou por receitas tributárias específicas, como os impostos, conforme ocorre em nosso ordenamento com o artigo 167, IV. Não é, portanto, um instrumento absoluto em um ordenamento jurídico, mas perfeitamente passível de alteração, desde que - repise-se - não seja considerado como cláusula pétrea.

Por conseguinte, a conclusão é que a vinculação de receitas - bem como o princípio da não afetação -, como qualquer norma jurídica, pode ser suprimida do ordenamento, desde que a vinculação - ou o próprio princípio da não vinculação - não seja cláusula pétrea dentro do ordenamento constitucional. Como subsídio a esta característica, é importante mencionar que não consideramos o princípio da não afetação no Brasil como garantidor dos direitos fundamentais, cuja erradicação não esbarraria nos óbices do artigo $60, \S 4^{\circ}$, IV da Constituição Federal, dado que mais se coaduna com uma técnica financeira para o bom andamento da atividade orçamentária estatal.

Todavia, pode-se considerar que as vinculações garantem algum direito fundamental a depender do entendimento sobre a sua função constitucional ${ }^{41}$. Sob esta

\footnotetext{
${ }^{38}$ Cf. o exemplo em CAMIC, Susannah. Earmarking..., p. 67.

${ }^{39}$ Ver item 1.3 infra quanto aos aspectos políticos das vinculações.

${ }^{40}$ Cf. ConTI, José Mauricio. A Autonomia Financeira do Poder Judiciário. São Paulo: MP Editora, 2006, p. 150. O jurista considera que o referido princípio não se configura cláusula pétrea, sendo perfeitamente possível haver vinculação de impostos por emenda constitucional.

${ }^{41}$ FERNANDO FACURY SCAFF (Para além dos direitos fundamentais do contribuinte: o STF e a vinculação das contribuições. In: SCHOUERI, Luís Eduardo (coord.). Direito tributário: homenagem a Alcides Jorge Costa. v. II. São Paulo: Quartier Latin, 2003, p. 1143) expõe, por exemplo, que as contribuições sociais serviriam para garantir os direitos humanos de segunda dimensão, ou seja, aqueles prestacionais, visto serem destinadas a todo um grupo social.
} 
ótica, caso um tributo vinculado seja uma forma de efetivá-los, não haverá a possibilidade de sua supressão, bem como da vinculação correlata. O mais comum, no entanto, é que a vinculação per se seja usada para supostamente garantir algum direito individual. Logo, a análise deverá cingir-se no tocante à finalidade da vinculação e se elas correspondem ao próprio direito garantido constitucionalmente ou, por outro lado, são meras ferramentas financeiras que auxiliam a sua concreção. Esta discussão merecerá atenção em momento oportuno $^{42}$.

\section{d) instrumento normativo veiculador}

Ponto coligado ao anterior é quanto ao instrumento normativo que deve veicular as vinculações. Neste sentido, EWAN Clague e JOEL GORDON ${ }^{43}$ expressam que:

O termo "vinculação" é usado frequentemente para expressar a relação direta que existe entre tributos e gastos quando a arrecadação dos tributos especiais é por lei destinada exclusivamente a certos gastos. (destacou-se)

Daí se infere outra característica da vinculação: ela deve ser positivada, ou seja, faz-se mister haver previsão normativa expressa que obrigue o agente público a predestinar os recursos a esta ou àquela atividade. Caso contrário, não haverá amarras legais ao gestor da coisa pública (administrador ou legislador) ${ }^{44}$, devendo seguir a regra geral da alocação de recursos segundo as prioridades definidas na peça orçamentária.

Tomando como base a dinâmica orçamentária pátria, não seria possível o estabelecimento de vinculações por decreto do Poder Executivo, uma vez que poderia ensejar a discussão se a lei orçamentária preponderaria sobre estes instrumentos normativos infralegais. Já no caso de uma afetação legal - e permitida constitucionalmente -, o critério de especialidade faria com que a lei específica sobre uma receita e despesa preponderasse sobre a lei orçamentária (geral, englobando o conjunto de receitas e despesas) $)^{45}$.

\footnotetext{
${ }^{42}$ Ver item 4.2.2.2 infra.

${ }^{43}$ Earmarking tax funds for welfare purposes. Social Security Bulletin. n. 3. jan. 1940, p. 10.

${ }^{44}$ Este ponto será mais bem desenvolvido no item "e" infra.

${ }^{45}$ Cf. neste sentido KelSEN, Hans. Teoria pura do direito. Trad. de MACHAdO, João Baptista. São Paulo: Martins Fontes, 2000, p. 228-32: Em caso desta aparente antinomia, deverá haver a resolução pelo cotejo hierárquico das normas ou, então, se houver normas de mesmo grau, pelo critério de especialidade perante a norma geral. A despeito do exposto, é importante salientar que este raciocínio não vale em países onde a peça orçamentária não possua o status formal de lei.
} 
Há quem entenda que a vinculação deva ser constitucional para que assim possa ser efetiva na prática. LAURA MARSILIANI e THOMAS RENSTRÖM ${ }^{46}$ entendem que se as vinculações tiverem certa maleabilidade, acarretando, portanto, mudança na destinação das receitas - ou ainda o uso da vinculação apenas na instituição de um tributo -, não serão efetivamente afetações. Outros autores, como FRANK ALEXANDER ${ }^{47}$, ao definir as vinculações (ou dedicated revenue source), entendem que a alocação automática deve se dar mediante lei. Após extensa análise, BRUCE Ely e HowARD Walthall ${ }^{48}$ chegam à conclusão de que a maior parte das vinculações nos estados americanos originou-se por meio de um instrumento infraconstitucional conhecido como statutory provision, ao invés de constarem nas suas respectivas Constituições, salvo algumas exceções - como os estados da Louisiana e Flórida, por exemplo. WILLIAM MCCLEARY ${ }^{49}$, ao conceituar as afetações, entende que são efetivadas, normalmente, por constitutional ou statute clauses.

Conforme dito, compreendemos que a vinculação pode ocorrer mediante qualquer ato normativo que não seja exclusivo do Executivo, visto que, neste caso, não haveria vinculação, uma vez que o próprio governante - ou seus sucessores - executor das políticas públicas poderia derrubá-la sem maiores dificuldades, bastando ato normativo posterior de mesma categoria rechaçando a afetação outrora estabelecida.

No caso da medida provisória no ordenamento brasileiro, enquanto não convertida em lei, não se pode caracterizar tal ato normativo como vinculação de receitas - visto que o próprio Poder Executivo poderá derrubá-la sob sua exclusiva discricionariedade. Além do mais, a medida provisória perde eficácia se não convertida em lei, pelo Congresso, após o transcurso do lapso estabelecido (artigo 62, $\S 3^{\circ}$, Constituição Federal). Após sua conversão, evidentemente, passa a ser uma vinculação de receitas, considerando que somente poderá ser alterada mediante nova lei. Ainda, em caso de majoração ou instituição de impostos, faz-se mister observar a restrição contida no parágrafo segundo do mesmo artigo.

\footnotetext{
${ }^{46}$ Time inconsistency in environmental policy: tax earmarking as a commitment solution. The Economic Journal. v. 110. mar. 2000, p. C124. Os autores citam como exemplo a Constituição de 1981 do Estado de Minnesota, cujo artigo XIV define a vinculação de tributos sobre o petróleo e motor de veículos. O produto arrecadado deve ser destinado a um fundo rodoviário.

${ }^{47}$ Financing affordable housing in Georgia: the possibility of a dedicated revenue source. Georgia State University Law Review. v. 13. 1997, p. 366, nt. 10.

${ }^{48}$ State constitutional limitations on taxing and spending: a comparison of the Alabama Constitution of 1901 to its counterparts. Cumberland Law Review. v. 33. 2003, p. 473.

${ }^{49}$ The earmarking..., p. 82.
} 
VINCENT ANESI ${ }^{50}$ ressalta que se estas rendas gravadas puderem ser desvirtuadas, não há razão para que a vinculação consista em constrição aos governantes, por exemplo. Apesar de adotar critérios econômicos neste raciocínio (fungibilidade da moeda), o autor chega à mesma conclusão inclusive com relação às normas constitucionais, expressando que "embora os governantes possam de uma forma ou outra contornar as regras constitucionais, isto levará certo tempo para que seja possível."

Porém, para o estudo das características jurídicas das vinculações, a possibilidade de alteração constitucional ou legal das normas não altera a sua característica impositiva enquanto vigente no ordenamento, que só pode ser sobreposta por decisão democrática do Parlamento (mediante nova lei ou emenda à Constituição), e não por ato do chefe do Executivo - como uma vinculação por decreto, por exemplo ${ }^{51}$.

A espécie normativa, logo, apenas veicula as vinculações de receitas. Conforme opinião de SUSANNAH CAMIC ${ }^{52}$, as vinculações não possuem os resultados apregoados pela doutrina por conta de algo inerente ou inato a elas, mas sim por causa de determinados mecanismos: (i) elas legalmente vinculam fundos a certos propósitos; e/ou (ii) elas simbolicamente obrigam o governo a manter o seu uso com o passar dos tempos; e/ou (iii) elas criam grupos de interesse que, embora não legalmente criados, institucionalmente comprometem os governos.

Desta forma, há outros elementos não jurídicos que também são responsáveis pela produção dos resultados almejados pelas vinculações. Uma vinculação simbólica ou institucional pode também produzi-los, cuja instrumentalização poder-se-á dar via vinculação normativa ${ }^{53}$. Logo, o mecanismo legal serve para dar a eficácia jurídica perquirida à afetação, mediante restrição na discricionariedade administrativa governamental ou limitação de liberdade na atividade legiferante estatal.

\section{e) exceção no ordenamento}

Para complementar o caráter jurídico das vinculações, é importante mencionar o seguinte postulado geral: em consagração à logicidade do sistema, as normas especiais (vinculações) derrogariam parcialmente a concepção orçamentária de que as receitas

\footnotetext{
${ }^{50}$ Earmarked taxation and political competition. Journal of Public Economics. v. 90. 2006, p. 682.

51 Com relação às alterações por decreto, é importante mencionar que, na Turquia, os fundos extraorçamentários eram estabelecidos por este instrumento normativo e com a subsequente aprovação de um Conselho de Ministros. Cf. MCClEARY, William. The earmarking..., p. 95.

${ }^{52}$ Earmarking..., p. 64.

${ }^{53}$ As duas características serão tratadas posterior e conjuntamente. Ver item 1.3 infra.
} 
devem ter a sua destinação no momento da feitura do orçamento - devendo, portanto, ser encaradas como exceções ${ }^{54}$.

As vinculações devem ser concebidas como ressalvas à dinâmica orçamentária, restringindo a liberdade do legislador ou do administrador público a depender de sua hierarquia normativa ${ }^{55}$. Uma vinculação estabelecida pela Assembleia Constituinte pode ser uma limitação na livre destinação de recursos ao legislador constitucional derivado (caso tal vinculação constitua-se em cláusula pétrea) ou ao legislador infraconstitucional; por sua vez, refletir-se-á, também, na atividade do administrador público. Este, em última instância, será o receptor da norma de vinculação, tendo em consideração que as vinculações acabam sendo instrumentos de limitação do Poder Legislativo dirigidos ao Poder Executivo.

É, deveras, uma desconfiança por parte do Legislativo acerca da possibilidade de desmandos pelos membros do Executivo, reduzindo a sua discricionariedade na alocação dos bens públicos ao impor um ato vinculado ao administrador, ainda que com isso possa reduzir o próprio âmbito de atuação da atividade legiferante ${ }^{56}$.

Ressalve-se que, para tanto, deve ser adotada a concepção de que (i) a liberdade do administrador público em matéria financeira engloba ampla margem de discricionariedade dada pelas normas orçamentárias, e que (ii) a influência de determinado grupo de interesse no orçamento não constituiria uma vinculação no senso jurídico, mas sim seria a sua faceta política, que também pode ser verificada na dimensão participativa do orçamento público por meio da representatividade popular. Assim, as vinculações viriam para reduzir essa discricionariedade na atuação do administrador público.

\footnotetext{
${ }^{54}$ Cf., nesse sentido, DerzI, Misabel de Abreu Machado. Arts. 40 a 47. In: MARTINS, Ives Gandra da Silva; NASCIMENTO, Carlos Valder do (org.). Comentários à Lei de Responsabilidade Fiscal. 2. ed. São Paulo: Saraiva, 2007, p. 293: "Vinculação é figura de exceção. A regra é o clássico princípio da não-afetação da receita de imposto (...)". Ver, mais especificamente, item 3 infra.

${ }^{55}$ Cf. MuzEllec, Raymond. Notions..., p. 234. O autor, ao mencionar o Relatório de M. Papon sobre a lei das finanças francesa de 1976, extrai um excerto que resume esta ideia: "As afetações de receitas devem, como boa regra, ter um caráter excepcional, e o Parlamento deveria se mostrar atento a isto, não autorizando sua multiplicação."

56 Cf. o conceito de atos vinculados em BANDEIRA DE Mello, Celso Antônio. Curso de direito administrativo. 25. ed. São Paulo: Malheiros, 2008, p. 422: “Atos vinculados seriam aqueles em que, por existir prévia e objetiva tipificação legal do único possível comportamento da Administração em face de situação igualmente prevista em termos de objetividade absoluta, a Administração, ao expedi-los, não interfere com apreciação subjetiva alguma". Com relação aos atos discricionários, entende o autor que "(...) seriam os que a Administração pratica com certa margem de liberdade de avaliação ou decisão segundo critérios de conveniência e oportunidade formulados por ela mesma, ainda que adstrita à lei reguladora da expedição deles." (destaques do original)
} 
Em breve síntese e atento a essa característica, o economista americano JAMES BUCHANAN $^{57}$ propõe uma releitura dos malefícios das vinculações por meio da individualidade tomada como ponto de vista, considerando que o Estado seria mero executor das vontades e objetivos almejados pelos cidadãos-eleitores. Assim, não haveria um Estado agindo independentemente, mas contando com a participação individual para a formação das decisões políticas; portanto, uma mudança de ponto de vista da autoridade em direção ao cidadão-eleitor fazia-se necessária.

Com uma eventual vinculação ou segregação de receitas - e a respectiva participação dos indivíduos na determinação destas afetações - poderia haver maior racionalidade e eficiência das escolhas individuais nos gastos públicos. Isto faria com que as vinculações fossem mais desejáveis em um sistema fiscal. Em suas conclusões, o economista ressalta, todavia, que este modelo deve ser dissociado das experiências políticas reais.

f) síntese

Com este apanhado e traçado o estado da arte, pode-se definir, no que toca ao seu caráter jurídico, que as vinculações de receitas são positivadas por instrumentos constitucionais ou legislativos de forma alheia à lei orçamentária, e são utilizadas para individualizar uma fonte e destinação mediante o estabelecimento de um elo jurídico entre receitas e escopos predeterminados, possuindo margem relativa de abolição do ordenamento e constituindo uma excepcionalidade à dinâmica orçamentária.

\subsection{CARÁter POLÍTICO}

\subsubsection{VINCULAÇÃO COMO PROCESSO POLÍTICO}

Na doutrina portuguesa, José JOAQUIM TEIXEIRA RIBEIRO ${ }^{58}$ explica a existência das vinculações sob dois conspectos. Um deles toca o caráter protetor vis-à-vis as recessões econômicas. Uma receita que fique vinculada às respectivas despesas seria, em tese, imune ao sacrifício de contenção de despesas estatais em épocas de crise e ausência de recursos. Estar-se-ia determinada despesa sob o invólucro da irredutibilidade pela ação estatal.

\footnotetext{
${ }^{57}$ The economics of earmarked taxes. Journal of Political Economy. 71. n. 5. oct. 1963, p. 458 e ss.

${ }^{58}$ Lições de finanças públicas. 5. ed. Coimbra: Coimbra Ed., 1997, p. 68.
} 
Porém, na opinião de EDWIN SMART e JOHN HART ${ }^{59}$, contextos de crise justamente são prejudicados com a vinculação, visto que há o pressuposto de que a prestação do serviço possa ser reduzida ou ampliada de acordo com a arrecadação do tributo vinculado ${ }^{60}$.

O segundo aspecto é no tocante ao benefício político da cobertura das despesas pelos seus próprios causadores, vinculando a receita auferida dos utentes de determinado serviço à sua melhoria e conservação. É o que ocorre nas estradas com o pedágio, por exemplo: o valor arrecadado pelo Estado é utilizado no custeio deste serviço público, remetendo ao princípio do benefício da doutrina econômica.

Isto facilitaria, para alguns, a aceitação do contribuinte para a expansão destes serviços, sobretudo nos países em desenvolvimento ${ }^{61}$, partindo-se de uma concepção macro-orçamentária para a estrutura micro-orçamentária na tomada de decisões em uma democracia direta, como no modelo proposto por ALEX ATHANASSAKOS ${ }^{62}$. Por evidente que, para tanto, as vinculações devem ser consideradas como instrumentos que aumentam a participação democrática ao se considerar a opinião do contribuinte no gasto público, concepção esta que não é pacífica, pois poderia ser também um instrumento utilizado para iludir os eleitores ${ }^{63}$.

Nos Estados Unidos, as características das vinculações estão intimamente ligadas a fatores político-institucionais. Na visão de SUSANNAH CAMIC ${ }^{64}$ - podem, ou não, envolver cada um dos três aspectos: precommitment ${ }^{65}$ (pré-comprometimento dos futuros governantes às gerações futuras), contributory (vinculada a benefícios retributivos, como o previdenciário: ao contribuinte é dada, posteriormente, a possibilidade de fruição de forma

\footnotetext{
${ }^{59}$ The Distribution of Revenues from State-Collected Consumer Taxes. Law \& Contemporary Problems. v.8. 1941, p. 474-75. Os autores relatam que as escolas de Ohio - que gozaram de rendas vinculadas do imposto sobre as vendas - não conseguiram reduzir a prestação do serviço para acompanhar o déficit arrecadatório deste imposto em épocas de crise. Há, inclusive, um caso interessante ocorrido em 1933 naquele estado, com a Assembleia vinculando um centavo do imposto sobre combustíveis líquidos para as escolas.

${ }^{60}$ SUSANNAH CAMIC (Earmarking..., p. 57), com base em estudos de ERIC PATASHNIK, expõe que as rendas de tributos vinculados nos Estados Unidos, nos últimos cinquenta anos, cresceram em épocas de arrecadação menor das receitas do orçamento geral, aumentando, outrossim, em épocas de mudanças políticas. Esta seria a razão histórica pelo sucesso das vinculações no ordenamento estadunidense.

${ }^{61}$ Cf. BuchanAN, James McGill. The economics..., p. 457 e nt. 3.

${ }^{62}$ General fund financing versus earmarked taxes: an alternative model of budgetary choice in a democracy. Public Choice v. 66. sept. 1990, p. 261.

${ }^{63}$ Cf. Wilkinson, Margaret. Paying..., p. 125.

${ }^{64}$ Earmarking..., p. 60.

${ }^{65}$ Cf. CAMIC, Susannah. Earmarking..., p. 64-65. Segundo a autora, o pré-comprometimento (precommitment) é algo que vincula as gerações e os governantes futuros em suas ações. Isto ocorre com as rendas vinculadas, que são retiradas das "vicissitudes do processo político-orçamentário". O precommitment é demonstrado pela autora com base nas ideias de STEPHEN HOLMES, no sentido de que as decisões presentes pré-comprometem os atos de seus sucessores, transformando-se em um paradoxo da democracia.
} 
direta e proporcional) e entitlement ${ }^{66}$ (quando é garantido um direito absoluto a um beneficiário), podendo haver combinação entre estas três características. Ressalte-se que esses aspectos fogem da alçada do caráter jurídico das vinculações. Desta feita, é possível afirmar que, v. g., a contribuição social paga pelo trabalhador vincula politicamente o poder público a permitir o seu gozo proporcional no futuro.

Quanto ao aspecto do pré-comprometimento - mais relevante para este estudo -, serve para dar estabilidade e previsibilidade ao sistema tributário estadunidense, visto que, conforme ventilado, vincula as receitas a determinados escopos entre gerações. As vicissitudes políticas não influiriam, desta forma, no fluxo de receitas e despesas ${ }^{67}$. Diante disto, é salutar a ponderação da autora:

Em um sentido literal da expressão, todos os tributos vinculados, por definição, envolvem pré-comprometimento, já que vincular rendas significa estabelecer uma destinação programática para determinada renda antes que esta seja coletada - i. e., "pré-comprometer" a renda. No entanto, quando os teóricos democráticos opõem-se ao pré-comprometimento, eles presumem que, quando um líder pré-compromete, ele necessariamente compromete alguém - que não é ele mesmo - a certas ações no curso das gerações futuras ${ }^{68}$.

Ressalva, no entanto, que tal consequência não é automática, principalmente em vinculações ad hoc. Por exemplo, a instituição de um tributo vinculado para ajudar vítimas de tsunami na Ásia ou de terremotos na América Central servirá para este fim, mas não "pré-comprometerá" os parlamentares futuros, visto que, atingido o seu objetivo, a sua razão de ser cessará ${ }^{69}$.

Logo, as vinculações implicam algum pré-comprometimento das rendas, mas não necessariamente o pré-comprometimento dos governantes futuros, o que rechaça a ideia de que a vinculação retira as decisões sobre o gasto público do processo democrático, pelo menos sob este ponto de vista ${ }^{70}$.

SUSANNAH CAMIC ${ }^{71}$ enxerga as vinculações como parte do processo político ao extrair os seus efeitos simbólicos e institucionais na sociedade. Conclui a autora que as vinculações não criam pré-comprometimentos - somente pela sua natureza - às gerações futuras, bem como não conseguem comprometê-las exclusivamente por meio de

${ }^{66}$ Cf. CAMIC, Susannah. Earmarking..., p. 69. Quando uma vinculação cria um entitlement, neste caso haveria a obrigação das gerações futuras em manter o tributo que o garantisse. Porém, lembra a autora que este instituto não conduz a uma garantia legal que futuramente deverá ser respeitada.

${ }^{67}$ Cf. CAMIC, Susannah. Earmarking..., p. 63-64.

${ }^{68}$ Cf. CAMIC, Susannah. Earmarking..., p. 65.

${ }^{69}$ Cf. CAMIC, Susannah. Earmarking..., p. 65-66.

${ }^{70}$ Cf. CAMIC, Susannah. Earmarking..., p. 67.

${ }^{71}$ Earmarking..., p. 69-70. 
mecanismos legais. Porém, um efeito que pode sortir sobre as linhagens futuras é o précomprometimento simbólico, já que o Congresso deverá trabalhar com a presunção de que tal benefício criado é aceitável pela sociedade e deve se manter a longo prazo. Desta maneira, a vinculação apareceria como uma prática aceitável que se perpetua.

Juntamente com estes pré-comprometimentos simbólicos, outros institutos comprometeriam as gerações futuras a observarem as vinculações: as teorias da path dependence e policy feedback viriam neste sentido $^{72}$. Desta forma, com base nestas correntes $^{73}$, cada decisão dos atuais governantes teria certa influência nas dos governantes futuros $^{74}$, e as políticas sociais implantadas pelas vinculações delimitariam os grupos de interesse que as defenderiam no futuro ${ }^{75}$. E quanto maior for a ligação entre o tributo e os beneficiários - isto é, quanto maior a definição do benefício gerado -, mais forte será a influência destes grupos para que a vinculação não seja erradicada ${ }^{76}$.

Com estes instrumentos e mecanismos, a estabilidade e previsibilidade do sistema tributário "vinculado" demonstrar-se-iam mais evidente, muito mais do que as receitas não vinculadas. Outro efeito vantajoso trazido é a progressividade na vinculação: considera-se que os mais abastados possam custear uma imposição maior do que aqueles menos afortunados. Destarte, estes mais ricos financiariam os benefícios dos mais pobres por meio de programas custeados pelas vinculações ${ }^{77}$.

Demonstrar-se-á, a seguir, como as vinculações aparecem na sua forma simbólica e institucional no ordenamento pátrio por meio de um caso concreto. Por fim, outro efeito político almejado pelas vinculações é a preconizada autonomia financeira, que será também analisado.

\footnotetext{
${ }_{72}^{72}$ Cf. CAMIC, Susannah. Earmarking..., p. 73.

${ }^{73}$ As bases destas teorias são explicadas em conjunto, em virtude da própria dificuldade doutrinária em diferenciá-las. Cf. CAMIC, Susannah. Earmarking..., p. 75, nt. 48.

${ }^{74}$ Cf. PIERSON, Paul. Increasing returns, path dependence, and the study of Politics. American Political Science Review. v. 94 . n. 2. jun. 2000, p. 252. Esta seria a definição ampla de path dependence. Sob uma concepção mais estrita - utilizada no trabalho do autor - englobaria a ideia de um processo de increasing returns, dado que os benefícios de uma atividade, comparada com outra opção, acrescem-se no decorrer do tempo. Desta forma, uma mudança ou retorno para outro "caminho" teria o seu custo social aumentado proporcionalmente ao lapso temporal percorrido.

${ }^{75}$ Cf. CAMIC, Susannah. Earmarking...., p. 73-74.

${ }^{76}$ Cf. CAMIC, Susannah. Earmarking..., p. 75.

${ }^{77}$ Cf. CAMIC, Susannah. Earmarking..., p. 77-80.
} 


\subsubsection{EXEMPLO DE VINCULAÇÃO SIMBÓLICO-INSTITUCIONAL DE RECEITAS: O CASO DAS UNIVERSIDADES PAULISTAS}

Primeiramente, para se traçar um panorama do caso ocorrido no Estado de São Paulo, insta ressaltar que a Constituição paulista possui despesa mínima obrigatória específica no tocante ao fomento à educação. Em obediência ao artigo 212, caput, da Constituição Federal, os Estados devem aplicar 25\% de sua receita resultante de impostos e transferências para a manutenção e desenvolvimento do ensino. A Constituição paulista prevê, no artigo 255 , caput, um aumento neste percentual para a cifra de $30 \%^{78}$.

$\mathrm{O}$ artigo 271, por outro lado, efetivamente vincula $1 \%$ da receita tributária estadual à Fundação de Amparo à Pesquisa do Estado de São Paulo (FAPESP), para fomentar o desenvolvimento científico e tecnológico ${ }^{79}$. E, por força do artigo 176, IV, da mesma Carta $^{80}$, existe a ressalva de possibilidade de vinculação de receitas para pesquisa científica e tecnológica, com esteio no permissivo existente no artigo $218, \S 5^{\circ}$, da Constituição da República.

O que também impende ser observado é que, na praxe orçamentária paulista, há sempre disposições na lei de diretrizes orçamentárias no tocante às verbas destinadas às universidades paulistas, a despeito de não haver comando na Constituição Estadual que obrigue à fixação de percentuais neste sentido.

Caso que merece menção ocorreu em 2005 quando do envio do Projeto de Lei $\mathrm{n}^{\circ}$ 224, pelo então Governador do Estado Geraldo Alckmin, à Assembleia Legislativa de São Paulo, referente à elaboração da lei de diretrizes orçamentárias do ano seguinte. Na ocasião, o artigo $4^{\circ}$ do referido esboço legal previa a destinação, às universidades estaduais, de 9,57\% da arrecadação do ICMS paulista, conforme vinha procedendo nos anos pretéritos. Constitui tal percentual uma vinculação simbólico-institucional do chefe do Executivo às universidades paulistas, por conta do compromisso de, ano a ano, destinar

\footnotetext{
${ }^{78}$ Artigo 255 - O Estado aplicará, anualmente, na manutenção e no desenvolvimento do ensino público, no mínimo, trinta por cento da receita resultante de impostos, incluindo recursos provenientes de transferências. Parágrafo único - A lei definirá as despesas que se caracterizem como manutenção e desenvolvimento do ensino.

${ }^{79}$ Artigo 271 - O Estado destinará o mínimo de um por cento de sua receita tributária à Fundação de Amparo à Pesquisa do Estado de São Paulo, como renda de sua privativa administração, para aplicação em desenvolvimento científico e tecnológico.

Parágrafo único - A dotação fixada no "caput", excluída a parcela de transferência aos Municípios, de acordo com o artigo158, IV, da Constituição Federal, será transferida mensalmente, devendo o percentual ser calculado sobre a arrecadação do mês de referência e ser pago no mês subseqüente.

${ }^{80}$ Artigo 176 - São vedados:

IV - a vinculação de receita de impostos a órgão, fundo ou despesa, ressalvadas as permissões previstas no art. 167, IV, da Constituição Federal e a destinação de recursos para a pesquisa científica e tecnológica, conforme dispõe o art. 218, § 5º da Constituição Federal;
} 
esta cifra a essas instituições por meio do processo de especialização nas leis orçamentárias, conforme exposto algures ${ }^{81}$.

Ocorre que houve a apresentação de emendas parlamentares ao referido projeto, alterando-se o percentual para se chegar a um patamar entre $10 \%$ e 11,8\%. Desta forma, a Comissão de Finanças e Orçamento da Assembleia Legislativa, por meio do Parecer $n^{\circ}$ 1033/2005, sugeriu uma subemenda "c" ao mencionado artigo $4^{\circ}$, cambiando o percentual para $10 \%^{82}$. O Relator Dep. Edmir Chedid, em seu parecer, aprovou a referida subemenda apresentada pela Comissão ${ }^{83}$ e o Relator Dep. Roberto Engler ${ }^{84}$, em voto separado, rejeitou a subemenda "c", argumentando que:

O percentual de $9,57 \%$ prende-se ao nível histórico de gasto e é compatível com a capacidade financeira estadual. Portanto, não vislumbramos a possibilidade de elevação desse percentual, ou a criação de percentual para o Centro Estadual de Educação Tecnológica Paula Souza, sem o comprometimento de outras prioridades de Governo, particularmente em outras áreas, também de cunho social, como é o caso do ensino público médio e fundamental.

A despeito destas considerações, o Projeto de Lei chegou ao Governador com o aumento do percentual e, mediante a Mensagem $n^{\circ} 76$ do Veto Parcial ao Projeto de Lei $n^{\circ}$ $224 / 05$, vetou este artigo no que se referia a este numeral (caput e parágrafo primeiro) ${ }^{85}$. A justificativa foi que o excessivo grau de recursos públicos para esta seara dificultava a alocação dos recursos disponíveis nas demais áreas de investimento estatal.

Diante disto, foi sancionada a Lei Estadual n 11.971, de 2005 (Lei de Diretrizes Orçamentárias de 2006), sem a previsão do custeio das despesas referentes às universidades estaduais em razão do mencionado veto parcial do Governador. Em 28 de setembro daquele ano, mediante uma votação simbólica na Assembleia, o veto do Governador foi mantido pelos Deputados 86 . O "lapso" somente foi remediado com o advento da Lei Orçamentária Anual de 2006 (Lei n 12.298/2006), publicada em 8 de

\footnotetext{
${ }^{81}$ Ver item 1.2, "b", supra.

82 Disponível em: <http://www.al.sp.gov.br/web/portal/ldo/texto.pdf>, p. 6. Acesso em: 28 jan. 2009. Inclusive, é mencionado que "As vinculações da manutenção e desenvolvimento do ensino público e também das Universidades nos parecem compatíveis com a capacidade financeira estadual. Qualquer mudança poderia comprometer outras prioridades."

${ }^{83}$ Disponível em: <http://www.al.sp.gov.br/web/portal/ldo/conclusao.pdf>. Acesso em: 28 jan. 2009.

${ }^{84}$ Disponível em: < http://www.al.sp.gov.br/web/portal/ldo/votosep.pdf>. Acesso em: 28 jan. 2009.

85 Disponível em: <http://webspll.al.sp.gov.br/internet/download.do?poFileIfs=5904817\&/mensagem 076.doc >. Acesso em: 28 jan. 2009.

${ }^{86}$ Perdas e ganhos: Veto de Alckmin ao aumento de recursos para a educação superior é mantido, mas governo propõe repasse equivalente a 9,67\% do ICMS para as universidades paulistas em 2006. Jornal da USP. 3 a 9 de outubro de 2005. ano XXI. n.739. Disponível em: <http://www.usp.br/jorusp/arquivo/2005/jusp739/pag03.htm>. Acesso em: 28 jan. 2009.
} 
março do respectivo ano. Na Seção V (Disposições Gerais), foi incluído o artigo 10 que anteviu o montante original de $9,57 \%$ da receita do $\operatorname{ICMS}^{87}$.

Porém, não havia tal previsão no Projeto de Lei n ${ }^{\circ}$ 700/2005 do Governador do Estado, o qual originou a referida lei orçamentária de 2006. Desta forma, por meio da emenda 9672, propôs-se o restabelecimento das disposições contidas no Projeto de Lei original da lei de diretrizes orçamentárias. No Parecer n $n^{\circ} 3472 / 2005$, da Comissão de Finanças e Orçamento sobre o Projeto da lei orçamentária anual, o Dep. Relator Vaz de Lima aprovou os termos da emenda - excerto este que merece transcrição:

No que diz respeito à emenda 9672, propõe que se destine às Universidades o valor de $9,67 \%$.

A matéria foi apreciada pela ocasião da Lei de Diretrizes Orçamentárias. Mesmo assim, considerando que em função de veto do Excelentíssimo Senhor Governador sobre a questão, o percentual proposto pelo Executivo desapareceu. Portanto, ao analisar a mensagem da proposta orçamentária para 2006, encaminhada a esta Casa, reafirma o Executivo a prioridade conferida ao ensino universitário, assegurando os recursos equivalentes ao percentual de 9,57\% da arrecadação do ICMS, acrescidos de 38,5 milhões de reais destinados à USP e UNICAMP. Tendo o Excelentíssimo Senhor Governador assumido o compromisso de executar plenamente o orçamento ora proposto, para as três universidades no exercício de 2006, e resgatando o que o Executivo apresentou na L.D.O., propomos a seguinte:

\section{SUB-EMENDA À EMENDA 9672:}

Inclua-se onde couber o seguinte artigo e seus parágrafos:

Artigo - Os valores dos orçamentos das Universidades Estaduais fixados na proposta orçamentária do Estado para 2006, devem ter as liberações mensais dos recursos do Tesouro respeitadas, no mínimo, o percentual global de 9,57\% (nove inteiros e cinqüenta e sete centésimos por cento) da arrecadação do Imposto sobre Operações Relativas à Circulação de Mercadorias e sobre Prestações de Serviços de Transporte Interestadual e Intermunicipal e de Comunicação - ICMS - Quota-Parte do Estado, no mês de referência.

$\S 1^{\circ}$ - À arrecadação prevista no "caput" deste artigo serão adicionados 9,57\% (nove inteiros e cinqüenta e sete centésimos por cento) das Transferências Correntes da União, decorrentes da compensação financeira pela desoneração do ICMS das exportações, energia elétrica e dos bens de ativos fixos, conforme dispõe a Lei Complementar $n^{\circ} 87$, de 13 de setembro de 1996, efetivamente realizadas.

$\S 2^{\circ}$ - O acréscimo de gastos para expansão de vagas no ensino superior público poderá ser custeado pela destinação de recursos suplementares, observados estudos relativos a esse fim.

\footnotetext{
${ }^{87}$ Artigo 10 - Os valores dos orçamentos das Universidades Estaduais fixados na proposta orçamentária do Estado para 2006 devem ter as liberações mensais dos recursos do Tesouro respeitadas com, no mínimo, o percentual global de 9,57\% (nove inteiros e cinqüenta e sete décimos por cento) da arrecadação do Imposto sobre Operações Relativas à Circulação de Mercadorias e sobre Prestações de Serviços de Transporte Interestadual e Intermunicipal e de Comunicação - ICMS - Quota-Parte do Estado, no mês de referência. $\S 1^{\circ}$ - À arrecadação prevista no "caput" deste artigo serão adicionados 9,57\% (nove inteiros e cinqüenta e sete décimos por cento) das Transferências Correntes da União, decorrentes da compensação financeira pela desoneração do ICMS de exportações, energia elétrica e dos bens de ativos fixos, conforme dispõe a Lei Complementar $\mathrm{n}^{\circ}$ 87, de 13 de setembro de 1996, efetivamente realizadas.

$\S 2^{\circ}-\mathrm{O}$ acréscimo de gastos para expansão de vagas no ensino superior público poderá ser custeado pela destinação de recursos suplementares, observados estudos relativos a esse fim.

$\S 3^{\circ}$ - O Poder Executivo dará continuidade ao programa de expansão do ensino superior público em parceria com as Universidades Estaduais.
} 
$\S 3^{\circ}$ - O Poder Executivo dará continuidade ao programa de expansão do ensino superior público em parceria com as Universidades Estaduais ${ }^{88}$.

Diante disto, com a sanção do Governador à referida emenda, o problema da omissão no tocante às receitas vinculadas às universidades paulistas foi enfim solucionado. Alguns questionamentos jurídicos poderiam ser feitos com relação a isto, tendo em vista que a aprovação das emendas no Projeto de lei orçamentária anual não era compatível com o disposto na lei de diretrizes orçamentárias, conforme prescreve o artigo 166, § $3^{\circ}$, I, da Constituição Federal e artigo $175, \S 1^{\circ}, 1$, da Constituição paulista ${ }^{89}$. Assim, as emendas à lei orçamentária anual seriam incompatíveis com a proposta enviada pelo Executivo, orientada de acordo com o veto existente na Lei de Diretrizes Orçamentárias de 2006.

Porém, análises da fase de elaboração da lei orçamentária e o encadeamento dos diplomas orçamentários não serão feitas de forma mais detida neste trabalho, merecendo apenas o registro em virtude de seus reflexos na análise de constitucionalidade. Isto porque a mera hipótese de que a lei orçamentária anual possa vir a ser aprovada, confirmando ou infirmando os termos questionados de uma lei de diretrizes orçamentárias, foi reconhecida como justificadora de seus efeitos concretos pelo STF na decisão da medida cautelar na ADI 2.018-7/PE, onde se discutia a limitação na participação do Poder Judiciário, Ministério Público, Tribunal de Contas e Assembleia Legislativa em determinados percentuais, vinculando-se uma quota-parte da receita de impostos. Na ocasião, o Sodalício tangenciou as questões relacionadas à vinculação de receitas, bem como quanto à extensão do termo órgão (i. e., considerando uma interpretação lata do termo órgão ou, então, restrita, não se incluindo, neste caso os Poderes) $)^{90}$.

Entendemos, todavia, a despeito destas questões processuais e em vista da inexistência de disposição constitucional que vincule a receita especificamente do $\operatorname{ICMS}^{91}$, o que ocorre faticamente é uma vinculação simbólico-institucional: o Estado, ao menos

${ }^{88}$ Disponível em: <http://webspl1.al.sp.gov.br/internet/download?poFilelfs=6922426\&/Par3472>. Acesso em: 28 jan. 2009.

${ }^{89}$ Cf. CONTI, José Mauricio. Da proposta orçamentária. In: ConTI, José Mauricio (coord.). Orçamentos públicos: a Lei 4.3620/1964 comentada. São Paulo: Revista dos Tribunais, 2008, p. 101. É oportuno apenas mencionar que não é outra a lição do jurista ao sintetizar o procedimento a ser adotado na elaboração da Lei Orçamentária Anual: "A lei orçamentária deve ser elaborada conforme o que foi estabelecido na lei de diretrizes orçamentárias e de forma compatível como o plano plurianual, de modo que se organize o sistema de planejamento da ação governamental."

${ }^{90}$ ADI 2.108-7/PE. Pleno. Rel. Min. Marco Aurélio. j. 17 dez. 1999. DJU 30 abr. 2004.

${ }^{91}$ E também há a impossibilidade de vinculação da receita de impostos, ainda que por meio de uma Constituição estadual, conforme apregoa o artigo 167, IV, da Constituição Federal. Por vedar a vinculação da receita de impostos, prevalece sobre o permissivo do artigo $218, \S 5^{\circ}$, que permite a vinculação de parcela da receita dos estados para fomento ao ensino. Nessa parcela das receitas deverá, portanto, ser excluída aquela de impostos. 
politicamente, tem o pré-comprometimento de destinar o percentual historicamente estabelecido, ainda que inexista comando legal ou constitucional que estabeleça uma vinculação. É mais uma das facetas dos mecanismos que imprimem os resultados desejados nas afetações.

O que poderia haver, com base no artigo 212 da Constituição Federal, correspondente ao artigo 255 da Constituição Estadual, era o estabelecimento de uma despesa obrigatória para as universidades paulistas. Por meio da adição de um parágrafo no referido artigo, poder-se-ia especificar o referido percentual de, no mínimo, 9,57\% sobre as receitas gerais para despesas destinadas a estas instituições. O que é altamente desaconselhável, em termos de gestão orçamentária, é a adição deste percentual aos $30 \%$ já estabelecidos como mínimo, pois se estaria engessando quase que $40 \%$ do orçamento estadual de impostos na área de educação, o que não constituiria a melhor técnica de governança estatal, por focar parcela considerável do orçamento em um só programa.

Por ser despesa obrigatória mínima, não há limitação constitucional em seu estabelecimento, sobretudo por conta da ressalva no artigo 167, IV, da Constituição Federal. Saliente-se, todavia, que não constitui boa prática legislativa o estabelecimento do percentual como teto, dado que, com o crescimento desta atividade e a imposição por novas necessidades, somente poderá haver percentuais maiores nas leis orçamentárias se a cifra de $9,57 \%$ for considerada apenas como mínimo, e não teto.

A desvantagem é que, em sendo incluído tal mínimo percentual via emenda constitucional, a sua alteração restaria mais dificultada na Assembleia Legislativa, de forma que, com a expansão do ensino universitário público paulista, deverá a lei de diretrizes orçamentárias prever um percentual adicional a este mínimo que estivesse garantido constitucionalmente. Já com a vinculação simbólico-institucional, os grupos de interesse ligados à educação poderão exercer sua influência na participação democrática a fim de aumentarem este percentual quando entenderem necessário; e, ademais, o Governo do Estado sempre terá o dever simbólico de manter esse montante com o passar dos anos. Neste sentido, lembra DINO JARACH ${ }^{92}$ que as vinculações costumam ocorrer para o resguardo dos indivíduos contra os humores e caprichos dos governantes de determinado interregno, a fim de garantir um serviço público específico, sendo esta uma faceta útil da vinculação de receitas.

\footnotetext{
${ }^{92}$ Finanzas Públicas y Derecho Tributario. Buenos Aires: Cangallo, 1993, p. 82-83.
} 


\subsubsection{VINCULAÇÃO COMO DOTADORA DE AUTONOMIA FINANCEIRA DOS PODERES}

Pode-se observar outra razão política de existência para uma vinculação (in casu, constitucional): garantir a autonomia financeira de algum dos Poderes dentro do Estado. É o que preleciona JosÉ MAURícIO CONTI ${ }^{93}$ no Brasil ao explicar que não há obstáculos constitucionais à vinculação de receitas de taxas ou contribuições ao Poder Judiciário, por exemplo, como a existente no artigo $98, \S 2^{\circ}$, da Constituição Federal ${ }^{94}$.

Quando se trata comumente do imperativo para que não haja a vinculação de receitas, justifica-se que serviria para conceder discricionariedade ao Poder Executivo e maior liberdade política ao poder constituinte derivado e infraconstitucional. Apregoa esta corrente que deveria haver maior participação do Legislativo na alocação das verbas públicas, principalmente pela atividade legislativa estatal que impediria eventuais reflexos conjunturais na efetivação do gasto público ${ }^{95}$. A vinculação de receitas viria, então, neste sentido.

Porém, algumas ponderações merecem ser destacadas. Com efeito, o Legislativo, assim como o Judiciário, deve participar do processo de alocação das verbas públicas. Todavia, isto já ocorre quando da elaboração das leis orçamentárias. O artigo 165 da Constituição Federal consigna que a iniciativa de elaboração do plano plurianual, da lei de diretrizes orçamentárias e da lei orçamentária anual é do Presidente da República, chefe do Poder Executivo. Mas tais projetos são, então, submetidos à sabatina do Congresso Nacional, cúpula do Poder Legislativo.

Já quanto ao Poder Judiciário, o sistema constitucional não prescinde de sua participação. O artigo 99 propõe que os tribunais elaborem as suas propostas orçamentárias e as encaminhem para subsidiar a elaboração da lei de diretrizes orçamentárias. O que a doutrina discute é que esta participação é um tanto quanto ínfima, prejudicando uma verdadeira autonomia financeira do Poder Judiciário.

\footnotetext{
${ }^{93}$ A Autonomia..., p. 148.

${ }^{94}$ Cf. CORTI, Horacio Guillermo. Derecho constitucional..., p. 313. Esta vinculação de receitas poderá ser de diversas formas: ou pela constituição de um fundo específico, ou, então, mediante a criação de uma conta especial separada dos fundos do Tesouro, conforme prevê a Ley n ${ }^{\circ} 23.853$ na Argentina, afetando recursos a um gasto em particular relacionado ao Poder Judiciário. RICARDO LOBO TORRES (Tratado de direito constitucional financeiro e tributário. v. 5: o orçamento na Constituição. 3. ed. Rio de Janeiro: Renovar, 2008, p. 345) também expõe a afetação trazida pela Emenda Constitucional $n^{\circ} 45$, de 2004, que vinculou a taxa judiciária ao Poder Judiciário.

${ }^{95}$ Cf. OliveIRA, José Marcos Domingues. Meio-ambiente - tributação e vinculação de impostos. Revista de Direito Tributário. São Paulo. v.15. n.56. abr./jun. 1991, p. 88-89.
} 
Em tese, não haveria óbices para que o Poder Judiciário participasse com mais ênfase do processo de elaboração orçamentária. JOSÉ MAURICIO CONTI ${ }^{96}$ ensina que o sistema de freios e contrapesos (checks and balances) e a adoção de funções atípicas pelos poderes não desnaturam a clássica concepção de repartição de poderes, visto que tal ideário não é absoluto, comportando, deveras, uma separação de funções, cujas atividades devem ser harmoniosas entre si. Desta forma, não configuraria tal hipótese uma desnaturação da ideia de função judicial que o Poder Judiciário deve resguardar.

Não há expressamente um montante numérico específico de verbas na Constituição brasileira consignado ao Poder Judiciário - porém, existe a ressalva do resguardo constitucional expresso de sua autonomia financeira no artigo 99, como ocorreu, e. g., com a recente Constituição do Equador de 2008, em seu artigo 168, item 2.

Diversamente, pode-se citar que a Constituição paraguaia prevê o montante mínimo de $3 \%$ do Orçamento-Geral a ser vinculado ao Poder Judiciário ${ }^{97}$. No mesmo sentido, há este estabelecimento de um percentual mínimo pela Constituição da Costa Rica $^{98}$. Já na Constituição argentina, há a previsão de mera administração dos recursos consignados por lei à Administração da Justiça, não garantindo, de forma cristalina, a vinculação mínima ao bom exercício da atividade judiciária ${ }^{99}$.

Igualmente é salutar apontar que a Constituição da Bulgária prescreve que o Poder Judiciário terá o seu orçamento próprio (art. 117), assim como a Assembleia Nacional (art. 62). É a consagração da autonomia financeira destes poderes, provavelmente em prol do princípio da separação dos poderes nesta nação. Neste mesmo embalo, a Constituição da Nicarágua estabeleceu que o Poder Judiciário terá não menos que $4 \%$ de receitas do Orçamento Geral (art. 159); o Poder Legislativo também obteve uma porcentagem de receitas - ainda que indefinida - garantida constitucionalmente pelo art. 132.

\footnotetext{
${ }^{96}$ A autonomia..., p. 24-25.

${ }^{97}$ Artículo 249 - De la autarquía presupuestaria

El Poder Judicial goza de autonomía presupuestaria. En el Presupuesto General de la Nación se le asignará una cantidad no inferior al tres por ciento del presupuesto de la Administración Central.

El presupuesto del Poder Judicial será aprobado por el congreso, y la Contraloría General de la República verificará todos sus gastos e inversiones.

${ }^{98}$ Cf. CONTI, José Mauricio. A autonomia..., p. 150.

99 Artículo 114: El Consejo de la Magistratura, regulado por una ley especial sancionada por la mayoría absoluta de la totalidad de los miembros de cada Cámara, tendrá a su cargo la selección de los magistrados y la administración del Poder Judicial.

(...)

Serán sus atribuciones:

(...)

3. Administrar los recursos y ejecutar el presupuesto que la ley asigne a la administración de justicia.
} 
Porém, conforme já exarado, é fecundo reforçar que o Judiciário é deveras prejudicado quando da feitura da peça orçamentária, haja vista a sua participação reduzida no procedimento de elaboração do orçamento ${ }^{100}$. Conforme lição comparativa de Luís CABRAL DE MonCADA ${ }^{101}$, o predomínio do Poder Executivo na elaboração das leis orçamentárias costuma ser absoluto e soberano em Portugal, diferentemente do que ocorre na França, onde a participação do Parlamento não é sobrepujada pela hipertrofia funcional do Executivo.

No Brasil, ocorre semelhantemente este domínio. É sugerido pela doutrina, então, como mais consentâneo ao resguardo da autonomia do Poder Judiciário, que não seja garantido um percentual fixo, mas sim, mínimo, tendo em vista que, com a progressividade no aumento das despesas, é natural que este percentual tenha que ser revisto a todo tempo, não se constituindo aquele tipo de fixação, destarte, na melhor técnica orçamentária ${ }^{102}$. Richard e PEgGY Musgrave ${ }^{103}$ expõem que os financistas sempre entenderam a vinculação como um "procedimento orçamentário pobre", justamente pela quantidade necessária para determinada despesa ser sempre variável, sendo ineficaz o estabelecimento de coeficientes a priori.

Também é proveitoso lembrar que os conceitos de autonomia e independência confundem-se; porém, a doutrina costuma entender que o conceito de independência é mais amplo, de forma a abranger a autonomia - a qual seria uma ferramenta para se atingir a independência. É por esta razão que se utiliza, neste caso, a expressão autonomia, pois apesar de um Poder não ser independente - isto é, ter receitas próprias-, deve dispor de autonomia financeira plena para poder atingir os seus desideratos constitucionais ou legais, sem que haja a intensa interferência de outros Poderes ${ }^{104}$.

\footnotetext{
${ }^{100}$ Cf. JÈzE, Gaston. Traité de science des finances. Paris: V. Giard \& E. Brière, 1910, p. 49-51. Procuramos, pelo uso dos termos peça e procedimento, tangenciar a acalorada discussão sobre a natureza jurídica do orçamento: se é uma lei propriamente dita, tanto uma lei como um ato, ou, em hipótese alguma, é lei, e sim ato. Ver também StouRM, René. Le budget..., p. 1-5, especialmente 4.

${ }^{101}$ Perspectivas do novo direito orçamental português. Coimbra: Coimbra Editora, 1984, p. 15-16.

${ }^{102}$ Cf. ConTI, José Mauricio. A autonomia..., p. 152-53.

${ }^{103}$ Hacienda publica teorica y aplicada. 2. ed. Trad. de LozAno IrUeSTE, José María. Madrid: Inst. de Estudios Fiscales, 1983.p. 340.

${ }^{104}$ Cf. ConTI, José Mauricio. A autonomia..., p. 55.
} 


\subsubsection{SÍNTESE DO CARÁTER POLÍTICO DAS VINCULAÇÕES}

$\mathrm{Na}$ esteira do expendido, destacaríamos o efeito político das vinculações: as afetações de receitas, como processo político, por meio de instrumentos simbólicos e institucionais pré-comprometem as gerações políticas posteriores, além de condicionar o rumo da aplicação dos recursos públicos nas decisões subsequentes e garantir a autonomia financeira a certos entes - como os Poderes da nação.

\subsection{CRITÉRIOS TEMPORAIS E VINCULAÇÃO A ÓRGÃOS PARAESTATAIS}

\subsubsection{VINCULAÇÃO DE RECEITA PARA DOTAR UM SERVIÇO PÚBLICO COM PATRIMÔNIO PARTICULAR}

A hipótese de vinculação para dotar de autonomia um serviço público verifica-se, comumente, com os tributos parafiscais e as taxas. O serviço público gozaria de uma gestão financeira afastada da hodierna, ou seja, do fundo comum ${ }^{105}$. Para parte da doutrina $^{106}$, este seria um meio mais cômodo de se garantir a independência de determinados serviços, bem como de alguns órgãos autárquicos. Lembra, neste sentido, MAURo SANTOS SiLvA ${ }^{107}$ que, v. g., os serviços de telecomunicações, radiofrequência, transporte, energia elétrica, recursos hídricos, petróleo e gás natural financiam as respectivas agências reguladoras no Brasil: Agência Nacional de Telecomunicações ANATEL, Agência Nacional de Transportes Terrestres - ANTT, Agência Nacional de Energia Elétrica - ANEEL, Agência Nacional de Águas - ANA e Agência Nacional do Petróleo, Gás Natural e Biocombustíveis - ANP.

Direcionar a regularidade dos fluxos de recursos financeiros a alguns serviços ou gastos é visto como vantajoso pela doutrina econômica:

(...) à medida que proteja determinadas políticas setoriais, cujos resultados dependam da sustentação financeira no longo prazo, das decisões políticas de curto prazo. Além

\footnotetext{
${ }^{105}$ Cf. SiMÕES, José Martinho. Finanças..., p. 653.

${ }^{106}$ Cf. Trotabas, Louis. Finances publiques. Avec la collaboration de CotTERET, Jean-Marie. 3. ed. Paris: Dalloz, 1969, p. 145.

107 Vinculações de receitas não financeiras da União. In: VIII Congreso Internacional del CLAD sobre la Reforma del Estado y de la Administración Pública. Panamá: [s.n.], 28-31 oct. 2003, p. 10. Disponível em: $<$ http://unpan1.un.org/intradoc/groups/public/documents/CLAD/clad0047828.pdf>. Acesso em: 11 mar. 2009.
} 
disso, contribui para a obtenção de maior eficiência no gasto público ao proteger investimentos em curso, de perdas decorrentes da interrupção de fluxos financeiros necessários à conclusão de programas e geração de resultados ${ }^{108}$.

O autor lusófono JOSÉ MARTINHO SIMÕES ${ }^{109}$ distingue a afetação a um serviço personalizado de um serviço com autonomia financeira. Somente o primeiro teria patrimônio próprio e dissociado do Estado, enquanto que, no segundo caso, estaria vinculado ao orçamento geral, dado que existiria apenas a cobertura de eventual déficit nas rendas especificadas para o serviço pelo próprio orçamento. Concordamos com o jurista, visto que um serviço público com autonomia financeira não significa que tenha orçamento próprio. Ele apenas será financiado pelos recursos gerados pela sua atividade, mas adicionamos - nem por isso estará impedido de receber recursos extras do orçamento para a sua melhoria, bem como no caso de déficit exposto pelo jurista.

A técnica de afetação a um serviço personalizado, segundo o financista, apresenta inúmeras vantagens, tendo em vista que, com o verniz da efetiva destinação dos recursos, os cidadãos-contribuintes sentem-se mais confortáveis ao contribuírem para uma entidade fora do ente estatal, em razão do pensamento de que os recursos efetivamente serão aplicados às finalidades pregadas pela instituição. Diferentemente, quando há o pagamento de tributos diretamente ao Estado, o sentimento de "egoísmo natural" dos contribuintes faz com que haja sempre desconfiança da real aplicação destes recursos em prol de si próprios e de toda a sociedade ${ }^{110}$. Percebe-se, portanto, o efeito psicológico na afetação de receitas deste tipo, facilitando o ingresso de um imposto novo no ordenamento tributário ${ }^{111}$.

Esta suposição advém da incerteza da aplicação dos recursos públicos. Conforme dispõe JosÉ DE RIBAMAR CALDAS FURTADO ${ }^{112}$, quando o contribuinte efetua o pagamento do imposto de renda, v. g., não sabe no que este valor se reverterá. Pode ser, dentre outros, em melhorias na saúde, educação, segurança ou infraestrutura. Adicione-se a isto o fato de que, comumente, nos países em vias de desenvolvimento, as necessidades públicas são tratadas de forma insatisfatória pelo Estado, de forma que, conjugado com a corrupção existente nestas nações, há a perene suspeita pública de malversação dos recursos estatais.

\footnotetext{
${ }^{108}$ Cf. Silva, Mauro Santos. Vinculações..., p. 2.

${ }^{109}$ Finanças..., p. 653-54.

${ }^{110}$ Cf. SIMÕES, José Martinho. Finanças..., p. 654. Esta é uma das razões expostas pelo autor justificadora da existência do princípio da não afetação: para evitar que pleitos individuais sobreponham-se às necessidades gerais do Estado. Ver também item 3.4 infra.

${ }^{111}$ Cf. TROTABAS, Louis. Finances..., p. 145.

$112 \mathrm{O}$ problema da vinculação de recursos orçamentários. Fórum de Contratação e Gestão Pública. Belo Horizonte. v.6. n.70. out. 2007, p. 50.
} 
A segunda vantagem é que tais recursos seriam geridos mais eficientemente e não ficariam ao sabor das decisões políticas inerentes à atividade de administração estatal, garantindo uma gestão mais proba destas verbas ${ }^{113}$. Por fim, haveria a garantia de responsabilização dos gestores deste patrimônio perante os tribunais e a sociedade, levando em consideração que seria uma atividade mais dócil identificar os gestores que malversem os recursos públicos caso estejam preestabelecidos a esta ou àquela entidade ${ }^{114}$.

Quanto aos inconvenientes, expõe JOSÉ MARTINHO SIMÕES ${ }^{115}$ que a concessão desta personalização dificulta, posteriormente, o retorno do serviço à "vala comum" e o seu respectivo custeio pelo orçamento geral, sobretudo em virtude dos próprios gastos já deflagrados por estes serviços que se tornariam mandatórios. Conforme demonstrado algures $^{116}$, é a questão do valor simbólico na vinculação de receitas - o que incrementa o custo político de sua supressão com o passar do tempo. A outra desvantagem é que a criação de contas especiais quebra a unidade orçamentária, incorrendo nos problemas já aventados quanto à dificuldade de controle dos gastos públicos.

Por fim, Mauricio Alfredo Plazas VeGA ${ }^{117}$ considera evidente a necessidade de autonomia à entidade paraestatal que presta o serviço: como há a vinculação do recurso a um setor em específico, não pode ela estar "submetida às regras gerais do orçamento senão ao critério próprio que os organismos encarregados de administrar os fundos de que se trata, naturalmente em um contexto de controle permanente por parte dos contribuintes."

A despeito das questões psicológicas apontadas na afetação a um serviço em particular, o critério da autonomia é o mais relevante a ser considerado para a questão da vinculação a alguns órgãos estatais, o que envolverá, portanto, o momento da arrecadação e destinação dos recursos a certa entidade (parafiscalidade).

\footnotetext{
${ }^{113}$ Ver item 1.1 supra.

${ }^{114}$ Cf. QUESADA, Sixto J. Las finanzas de la República Argentina. Buenos Aires: Impr. M. Biedma, 1892, p. 69. O insigne economista argentino, em manifesto contra a má-administração financeira da Argentina, conceitua que a boa administração “(...) é o funcionamento regular de todos os recursos que compõem a máquina do Estado; é a claridade e a ordem em tudo o que se relaciona com a coisa pública; é o cumprimento estrito da Constituição e das leis; é a previsão e o tato em todos os atos do Governo, e o pleno conhecimento que os membros deste devem ter do estado do país, tanto político como financeiro, para poderem aplicar eficazmente as medidas que sejam necessárias à manutenção do equilíbrio, salvando assim as más situações produzidas pelos casos fortuitos."

${ }^{115}$ Finanças..., p. 653-55.

${ }^{116}$ Ver item 1.3 supra.

${ }^{117}$ Los tributos vinculados. Revista Estudios Socio-Jurídicos. Santa Fé de Bogotá. v.2. n.1. mar. 2000, p. 162-63.
} 


\subsubsection{MOMENTO DA ARRECADAÇÃO DA RECEITA}

O artigo 57 da Lei $n^{\circ}$ 4.320/64 classifica como receita orçamentária "tôdas as receitas arrecadadas, inclusive as provenientes de operações de crédito, ainda que não previstas no Orçamento." Desta forma, a definição temporal de receita orçamentária abarcaria somente as efetivamente arrecadadas, sendo este também o conceito dado pela doutrina $^{118}$.

Questão que é constantemente levantada nas Ações Diretas de Inconstitucionalidade junto ao Supremo Tribunal Federal é quanto à importância de se determinar se a vinculação é realizada antes ou depois da entrada da receita nos cofres públicos. Na ADI $n^{\circ} 1.750-3 / \mathrm{DF}^{119}$, decidiu-se que tal critério é irrelevante, visto que, na prática, o efeito seria o mesmo.

Contudo, o Ministro Nelson Jobim ${ }^{120}$, em seu voto no julgamento da Medida Cautelar da mesma ADI, ventilou que pode haver dúvidas quanto às receitas não arrecadadas, id est, aquelas em que há a obrigação de pagar ao Erário, mas que ainda não foi adimplida pelo contribuinte.

Recorda que o direito financeiro não costuma diferenciar receita arrecadada e arrecadável, incluindo-as como espécie do gênero entrada ${ }^{121}$. Ocorre que entrada ${ }^{122}$, segundo a doutrina, é qualquer valor que ingresse nos cofres públicos, independentemente de alguma razão prévia $^{123}$. Observa-se que, a rigor, o conceito de receita (entrada

${ }^{118}$ Cf. OliveIRA, Regis Fernandes de. Curso de direito financeiro. 2. ed. São Paulo: RT, 2008, p. 103: "Sinteticamente, pode-se dizer que receita é a entrada definitiva de dinheiro e bens nos cofres públicos." (grifos do original)

${ }^{119}$ ADI 1.750-3/DF. Pleno. Rel. Min. Eros Grau. j. 20 set. 2006. DJU 13 out. 2006: "AÇÃO DIRETA DE INCONSTITUCIONALIDADE. LEI COMPLEMENTAR DISTRITAL N. 26/97. CRIAÇÃO DO PROGRAMA DE INCENTIVO ÀS ATIVIDADES ESPORTIVAS MEDIANTE CONCESSÃO DE INCENTIVO FISCAL ÀS PESSOAS JURÍDICAS. CONTRIBUINTES DO IMPOSTO SOBRE PROPRIEDADE DE VEÍCULOS AUTOMOTORES. VIOLAÇÃO DO DISPOSTO NO ARTIGO 167, INCISO IV, DA CONSTITUIÇÃO DO BRASIL. (...) 2. O ato normativo atacado a faculta vinculação de receita de impostos, vedada pelo artigo 167 , inciso IV, da CB/88. Irrelevante se a destinação ocorre antes ou depois da entrada da receita nos cofres públicos. (...)" (destacou-se)

${ }^{120}$ ADI-MC 1.750-3/DF. Pleno. Rel. Min. Nelson Jobim. j. 18 jun. 1998. DJU 14 jun. 2002, p. 163 e ss.

${ }^{121}$ ADI-MC 1.750-3/DF, p. 166-68.

${ }^{122}$ Cf. Del Federico, Lorenzo. Tributi Paracommutativi e finanziamento dei servizi pubblici. Caso italiano e prospettive europee. Rivista di Diritto Finanziario e Scienza delle Finanze. Milano. v.62. n.2, 2003, p. 25556. $\mathrm{O}$ autor, em seu introito, faz uma listagem dos tipos de entrada utilizados para fazer frente às despesas públicas. Pode-se distinguir, nestas modalidades, o preço privado, baseado na contratação de mercado, portanto, superiores ao custo do bem/serviço; o preço público, que serve apenas para cobrir o custo do bem/serviço; o preço político, que é a quota pela requisição ao Estado a fim de usufruir de um serviço público (taxa) ou advinda da valorização oriunda de uma obra (contribuição de melhoria); o preço de monopólio, onde se impõe um imposto sobre o preço do monopólio; e, por fim, os impostos, que servem para custear os serviços gerais indivisíveis do Estado.

${ }^{123}$ Cf. OliveIRA, Regis Fernandes de. Curso..., p. 101-02. 
definitiva) requereria a entrada dos valores nos cofres públicos, de forma que o montante arrecadável não seria receita propriamente dita segundo os cânones financeiros. Desta forma, pela argumentação meramente conceitual, não estaria este tipo de receita enquadrada na vedação do artigo 167, IV da Constituição Federal.

É sobremaneira importante o registro de uma característica da definição de receita de OSCAR JosÉ DE PláCIDO E SILVA ${ }^{124}$, que pode dirimir estas contendas doutrinárias sobre o conceito de receita:

E êste sentido financeiro, não se afasta do sentido vulgar: receita, da forma feminina de receptus, recebido, compreende toda soma de dinheiro recebida.

Nesta razão, receita pública exprime uma totalidade e sòmente poderá, a rigor, ser encarada por um todo. (destaques do autor)

Deveras relevante, portanto, o momento do recebimento do dinheiro pelos cofres públicos, consoante a definição supramencionada. Conquanto não haja o esmiuçamento deste impasse no voto, o Ministro claramente procurou, sabiamente, optar por uma interpretação teleológica do conceito. Caso não se estendesse tal proibição às receitas não arrecadadas, poderia haver, e. g., a massiva vinculação de receitas a órgãos e fundos por meio de normas infraconstitucionais de forma a acorrentar demasiadamente o orçamento. $\mathrm{E}$ mais: caso não se entendesse que os recursos não arrecadados não fossem futuras receitas, em tese não haveria razão para a existência de vedação à vinculação da receita de impostos, dado que o recurso poderia ser consignado antes de sua arrecadação. Tal ideia é, a nosso ver, inconcebível sob uma interpretação racional do instrumento das vinculações.

Defendemos, destarte, um conceito mais amplo de receitas. O critério da não arrecadação não pode ser considerado para fins de vinculação, caso contrário constituiria burla oblíqua à regra da não afetação de receitas. Recursos não arrecadados são impassíveis de vinculação: a partir do momento do surgimento da obrigação de pagar o tributo, o caixa público passa a ser o destinatário dos recursos auferidos em razão desta obrigação, e, desta forma, este montante estará sujeito à não afetação de receitas.

Logo, caminho lógico é que os recursos dos impostos sejam receitas, pois devem compulsoriamente adentrar nos cofres públicos. A obrigação tributária é compulsória, consoante prescreve o artigo $3^{\circ}$ do Código Tributário Nacional, e deverá ser adimplida pelo contribuinte, sob pena de excussão de seu patrimônio. E, em se admitindo a possibilidade de destinação ou vinculação de recursos sem a respectiva entrada ao Tesouro, estar-se-ia

\footnotetext{
${ }^{124}$ Vocabulário..., p. 116.
} 
burlando também os princípios da universalidade e unidade insculpidos no artigo $2^{\circ}$ da Lei $\mathrm{n}^{\mathrm{o}} 4.320 / 64^{125}$.

Porém, definida esta linha de raciocínio, emerge o problema da parafiscalidade, ou seja, se ela seria, ou não, uma forma de vinculação de receita, visto que não haveria a entrada destes recursos na disponibilidade orçamentária. $\mathrm{O}$ destinatário não seria o caixa público, mas sim uma entidade paraestatal, o que plantaria dúvidas na conclusão ora exarada.

\subsubsection{TRIBUTOS PARAFISCAIS E AFETAÇÃO DE RECEITAS}

\section{Louis Trotabas e Jean-Marie Cotteret ${ }^{126}$, juntamente com Maurice} DUVERGER $^{127}$, argumentam que os tributos parafiscais também seriam uma forma de afetação de receitas, pois atribuem os recursos arrecadados a certos organismos ou

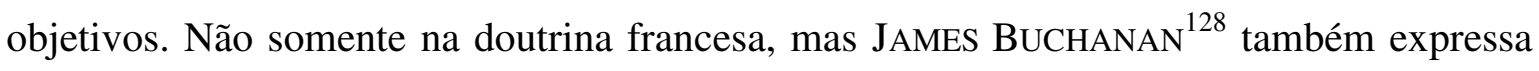
que a vinculação em regra:

(...) é usada com referência ao comprometimento de uma fonte tributária a um determinado serviço dentro de um sistema de tributos (multitax) e de unidades fiscais de serviços públicos (multiservice fiscal unit) múltiplos, mas os mesmos efeitos são produzidos na criação de unidades fiscais com propósito específico, como distritos escolares, de combate a incêndio e sanitários, cada um destes com concessão de poderes tributários independentes, porém, restritos. (destacou-se)

É oportuno também notar que, na Espanha, FERNANDo SAINZ DE BuJANDA ${ }^{129}$ menciona que o produto das exações parafiscais, cuja arrecadação constitui fundos públicos fora do orçamento (sob os auspícios da Ordem de 23 de julho de 1960), é depositado em uma conta única, inclusive com rubrica orçamentária específica.

Na verdade - segundo HENRY LAUFENBURGER ${ }^{130}$-, é notada uma das faces do dirigismo econômico: quer pela criação de recursos parafiscais, quer pela afetação de receitas orçamentárias. No primeiro caso, as corporações profissionais e os sindicatos são um exemplo de clareza solar desta faceta. Em virtude deste dirigismo, ALIOMAR

\footnotetext{
${ }^{125}$ Ver itens 3.5.1 e 3.5.2 infra.

${ }^{126}$ Droit..., p. 61.

${ }^{127}$ Finances publiques. Paris: Presses Universitaires de France, 1950, p. 321.

${ }^{128}$ The economics..., p. 458.

${ }^{129}$ Notas de derecho financiero. Seminario de derecho financiero. Tomo I: introducción y parte general. v. III. Madrid: Universidad de Madrid, 1975, p. 637.

${ }^{130}$ Traité d'économie et de législation financieres : budget et Trésor. 3. ed. Paris: Sirey, 1948, p. 56.
} 
BALEEIRO $^{131}$ ressalta que a parafiscalidade teria uma importância muito maior do ponto de vista econômico do que jurídico, característica esta igualmente observada pela constatação de HeNRy LAUfENBURGer.

É um instituto que ganhou grande relevância no pós-Segunda Guerra Mundial, com o aumento das entidades voltadas a atividades de interesse geral, mas específicas no estabelecimento de benefício a determinado grupo ou setor. A origem do termo parafiscal remonta a "um documento oficial francês de 1946, conhecido como 'Inventário Schuman' (inventário do Ministro Schuman sobre a situação financeira), e foi admitido no ordenamento da França, pela primeira vez, em um decreto de 9 de dezembro de 1948" ${ }^{132}$.

No direito tributário, a parafiscalidade é definida por PAULO DE BARROS CARVALHO ${ }^{133}$ como o “(...) fenômeno jurídico que consiste na circunstância de a lei tributária nomear sujeito ativo diverso da pessoa que a expediu, atribuindo-lhe a disponibilidade dos recursos auferidos, para o implemento de seus objetivos peculiares." Importante característica é o sujeito ativo envolvido na arrecadação tributária. Desta forma, caso ele transfira os recursos ao ente político, não se configuraria o fenômeno da parafiscalidade. Além desta definição jurídica, RAYMOND MuZELLEC ${ }^{134}$ ressalta que, do ponto de vista econômico, ela possui certa originalidade pelo fato de extirpar o caráter de imposição à coletividade para incidir sobre as pessoas diretamente interessadas.

Ocorre saber se a parafiscalidade seria ou não uma forma de vinculação de receitas, dúvida esta realmente pertinente implantada pela doutrina: existe, inclusive, a denominação de "impostos especiais ou de afetação" para as contribuições parafiscais ${ }^{135}$. Em rigor, ao se considerar o momento da arrecadação aos cofres públicos como irrelevante, a parafiscalidade integraria uma das formas de vinculação de receitas. Entretanto, se este critério temporal for relevante para a sua caracterização, a parafiscalidade, em regra, não seria uma forma de afetação.

Para se chegar a este critério, deve-se, no entanto, abstrair a conceituação tributária do instituto e a celeuma instaurada ao seu redor - cabendo apenas observar que a doutrina majoritária pátria entende que a afetação das receitas das contribuições parafiscais

\footnotetext{
${ }^{131}$ Limitações Constitucionais ao Poder de Tributar. 5. ed. Rio de Janeiro: Forense, 1977, p. 281.

${ }^{132}$ Cf. PlazAs Vega, Mauricio Alfredo. Los tributos..., p. 149-50.

${ }^{133}$ Curso de direito tributário. 17. ed. São Paulo: Saraiva, 2005, p. 237.

${ }^{134}$ Notions..., p. 230. Para que ela se verifique sob esta ótica, faz-se mister a verificação de três hipóteses: a) necessidade de interesse geral não coberto pela fiscalidade clássica; b) órgão que responda a esta necessidade e que seja distinto do Estado, das comunas, dos departamentos e de seus estabelecimentos públicos administrativos; e c) técnica de financiamento para fazer face a esta necessidade.

135 Cf. Plazas Vega, Mauricio Alfredo. Los tributos..., p. 153, acerca da exposição da existência desta terminologia.
} 
as diferencia das demais espécies tributárias, havendo autores que as entendem como impostos ou taxas ${ }^{136}$.

Considerável é saber, portanto, se a parafiscalidade é apenas uma técnica que utiliza a afetação a um fim específico, como nas contribuições parafiscais - destarte, perfazendo um tributo vinculado a uma atuação do Estado, de forma direta (como as taxas e contribuições) ${ }^{137}$ ou indireta (como as contribuição de melhoria) ${ }^{138}$-, ou uma vinculação de receitas públicas propriamente dita.

Os tributos parafiscais não são uma forma de vinculação de receitas públicas, dado que os recursos não adentram na disponibilidade orçamentária do ente federativo. $\mathrm{O}$ montante auferido em razão do tributo servirá para a própria pessoa ou entidade implementar a consecução de seus objetivos ${ }^{139}$. É oportuna a lição de GERALDO ATALIBA ${ }^{140}$ neste sentido, ao mencionar que "são recursos não arrolados no orçamento estatal”, despontando em "peças paraorçamentárias." PAULO DE BARROS CARVALHO ${ }^{141}$, inclusive, destaca que o fato de não haver a transferência dos recursos ao ente político é justamente um dos fatores que indica a ocorrência da parafiscalidade.

Este seria o núcleo que a distinguiria da fiscalidade, visto que esta implica a arrecadação dos tributos pelo Estado no orçamento público. MAURICIO ALFREDO PLAZAS VEGA $^{142}$ chega, inclusive, a ressaltar a existência da nomenclatura paraorçamentárias (parapresupuestales), dada a característica de não agregação das receitas ao caixa único estatal. Desta forma, destaca que "são 'parafiscais' e 'paratributários'; não porque não tenham natureza 'tributária', senão porque, por suas peculiares características, não têm o destino próprio dos tributos nem se confundem com a conta comum dos ingressos públicos."

\footnotetext{
${ }^{136}$ Cf. PAmPLona, Karla Marques. Contribuição parafiscal como instrumento de política fiscal em prol dos direitos humanos. [s.1.]: [s.n.], [20--], p. 4, nt. 18, quanto à listagem dos autores que defendem cada uma destas correntes. Disponível em: $<$ http://www.conpedi.org/manaus/arquivos/Anais/Karla\%20Marques\%20Pamplona.pdf $>$. Acesso em: 16 out. 2008.

${ }^{137}$ Cf. ATALIBA, Geraldo. Destinação do produto da arrecadação de tributo - emenda Calmon - despesas com educação. Revista dos Tribunais. São Paulo. v.75. n. 612. out. 1986, p. 18. "É que os tributos vinculados (taxas e contribuições), por sua própria natureza, têm sua destinação presa à atividade pública que deu ensejo à própria relação tributária."

${ }^{138}$ Cf. Carvalho, Paulo de Barros. Curso..., p. 35-36. O autor entende que as contribuições não são categorias à parte, mas sim ora tributos vinculados, ora impostos, conforme exposto no parágrafo acima.

${ }^{139}$ Cumpre mencionar a hipótese, inclusive, de uma pessoa física ser o sujeito ativo da relação jurídicotributária, conforme explica PAulo De Barros CARVAlHo (Curso..., p. 301). Desta feita, fica prejudicada qualquer alegação de que tais recursos ingressam efetivamente nos cofres públicos.

${ }^{140}$ Hipótese de Incidência Tributária. 6. ed. São Paulo: Malheiros, 2005, p. 189.

${ }^{141}$ Curso..., p. 237.

${ }^{142}$ Los tributos..., p. 150 e 155.
} 
No caso dos tributos parafiscais, eles não se constituem em receita, visto não estarem dentro da possibilidade de o Estado dispor sobre estes recursos. Partindo-se desta premissa, os tributos parafiscais não seriam propriamente vinculações de receitas; considerando que não há a efetiva arrecadação (entrada nos cofres públicos), constituem-se em fenômenos paraorçamentários, de onde se coligem inúmeras consequências - uma delas é a não aplicação dos princípios orçamentários, máxime o princípio da integralidade orçamentária, conforme aponta AURÉLIO PITANGA SEIXAS FILHO ${ }^{143}$ no tocante às contribuições parafiscais.

Além disso, em nossa visão, a parafiscalidade não é fenômeno que afeta recursos a um escopo ou despesa, mas sim os destina a um sujeito ativo que deverá empregá-los na consecução de suas atividades. Um sindicato, com a arrecadação das contribuições sindicais, pode aplicar livremente estes recursos em suas finalidades, desde que de acordo com a representação da categoria. Neste sentido, ALFREdo AUGUSTO BECKER ${ }^{144}$, em lição magistral, ressalta que a parafiscalidade serve para certas atividades que dependam de autonomia técnica e financeira ${ }^{145}$. Para haver a referida autonomia, não pode haver sujeição ou subordinação a normas orçamentárias que são aplicadas às repartições públicas, por exemplo.

Por conseguinte, e tendo em consideração esta peculiaridade da parafiscalidade, nada impede que os recursos públicos fiquem com o sujeito ativo que os arrecadou para a promoção de suas atividades - sendo esta, aliás, a característica primordial que a difere dos demais fenômenos financeiro-tributários. Neste caso, não obstante inexistir a constituição de tal montante como receita pública, há a hipótese de controle e fiscalização destas quantias, o que denota o caráter público a estas verbas ${ }^{146}$. Com isto, é forçoso concluir que

\footnotetext{
${ }^{143}$ A integralidade orçamentária e as contribuições. Revista Tributária e de Finanças Públicas. São Paulo. v. 12. n. 59. nov./dez. 2004, p. 222-23. O princípio da integralidade - cumpre mencionar - engloba os princípios da universalidade e unidade, segundo a terminologia usada por DINO JARACH (Finanzas..., p. 8283).

${ }^{144}$ Teoria Geral do Direito Tributário. 2. ed. São Paulo: Saraiva, 1972, p. 349.

${ }^{145}$ Quanto à autonomia financeira, ver item 1.3.3 supra.

${ }^{146} \mathrm{O}$ artigo 70, parágrafo único, da Constituição Federal prescreve que prestará contas qualquer pessoa física ou jurídica que “(...) utilize, arrecade, guarde, gerencie ou administre dinheiros, bens e valores públicos ou pelos quais a União responda, ou que, em nome desta, assuma obrigações de natureza pecuniária." Neste mesmo diapasão, o artigo 71 da Constituição Federal, em seu inciso II, também registra que cabe ao Tribunal de Contas julgar os responsáveis por quaisquer recursos públicos. Desta forma, a expressão dinheiro, bens e valores públicos abarca não somente o conceito de receita pública, mas também o de quaisquer montantes e quantias que tenham a sua origem em alguma relação pública ou de Direito Público. Este é o sentido empregado pelo texto constitucional quando disciplina acerca da fiscalização financeira e que deve ser entendido no que concerne às vinculações de receitas. $\mathrm{O}$ fato de os recursos ficarem, nos limites legais, à mercê do nuto do sujeito ativo arrecadador não se lhe confere o status de orçamento público. São recursos públicos que não integram o orçamento (paraorçamentários) e geridos para as atividades-fins dos entes beneficiados.
} 
tais recursos não ingressam na disponibilidade do orçamento geral, consubstanciando-se em recursos próprios da entidade que o arrecada, rematando as tentativas em se tentar fixar tais verbas na categoria de receitas.

Por fim, é oportuno registrar a opinião de MAURicio Alfredo PlaZAS VEGA ${ }^{147}$ de que a parafiscalidade seria uma exceção ao princípio da universalidade e à unidade de caixa justamente por serem paraorçamentários ${ }^{148}$. Entendemos que não se trataria de uma exceção a estes princípios, uma vez que são recursos que não pertencem ao orçamento. Caso fossem assim encarados, deveriam ser operacionalizados por orçamentos anexos, contas especiais, fundos ou outro instrumento orçamentário ${ }^{149}$.

Posto isto, ressaltamos que a vinculação de receitas não se confunde com a técnica parafiscal, visto que a parafiscalidade é a possibilidade de destinação de recursos a um sujeito ativo para a consecução de suas atividades específicas com certa autonomia, não sendo considerados dentro da disponibilidade orçamentária do ente federativo por se tratar de um fenômeno paraorçamentário.

\subsubsection{REDIRECIONAMENTO DE RECEITAS PÚBLICAS}

Após analisada a possibilidade de parafiscalidade em recursos paraorçamentários, volve-se à hipótese de vinculação de receitas orçamentárias. Aqui, cabe outra indagação: se, em tese, algumas receitas (como as oriundas de taxas) devem ficar com os entes estatais responsáveis pelo recolhimento, haveria a possibilidade de vinculá-las a entidade diversa da prevista para a consecução do objetivo colimado, sob claro mecanismo regedor de um redirecionamento interno de receitas no ente federativo?

A vinculação pelo redirecionamento receitas surge quando um ente da federação destina suas receitas para outro ente de sua própria Administração, como sói acontecer no caso de redirecionamento de receitas de autarquias, $\nu$. $g$., para órgão diverso ou mesmo outra autarquia da Administração Pública. É como se ocorresse a vinculação das receitas obtidas pelo Hospital das Clínicas de São Paulo (autarquia), em razão de sua atividade relacionada à saúde, para a SABESP (sociedade de economia mista) expandir o setor de saneamento básico no Estado.

\footnotetext{
${ }^{147}$ Los tributos..., p. 163.

${ }^{148}$ Ver, quanto aos princípios, respectivamente os itens 3.5.2 e 3.5.1.2 infra.

${ }^{149}$ Ver itens 3.6 e 4.1 infra.
} 
Um exemplo prático deste redirecionamento de receitas públicas pode ser extraído do Projeto de Lei paulista $n^{\circ} 655 / 2008^{150}$, de autoria do Deputado Otoniel Lima ${ }^{151}$ do Partido Trabalhista Brasileiro - PTB, que institui a vinculação de receitas de concessionárias operadoras de rodovias. Segundo o referido projeto, há a proposta de vincular R\$ 0,25 do pedágio cobrado pelo DER - Departamento Estadual de Rodagem, autarquia - e da DERSA - Desenvolvimento Rodoviário S/A, sociedade de economia mista - à Secretaria de Segurança Pública, que seria repassado em forma salarial aos funcionários públicos albergados por esta Secretaria ${ }^{152}$.

O citado dispositivo estabelece, por conseguinte, a vinculação das receitas dos pedágios à Secretaria de Segurança Pública, que se encarregará de repassá-las aos funcionários do setor mediante reajustes salariais e outras benesses ${ }^{153}$. Tirante o objetivo político de satisfação classista que esta norma proscreve, há a vinculação das receitas de um órgão público autárquico (DER) e dos recursos de uma empresa de sociedade de economia mista (DERSA), redirecionando-as a outra seara da Administração Pública.

Sob a égide do disposto no artigo 167, IV, da Constituição Federal, esta seria uma hipótese possível de vinculação de preços públicos a finalidades específicas. Porém, a ilegalidade deste Projeto de Lei é perceptível sob outro ângulo, pois neste caso deve se levar em conta a autonomia financeira destes entes. Este entendimento pode ser verificado pelo Supremo Tribunal Federal, apesar de não tratar diretamente sobre o redirecionamento de receitas; destarte, o princípio da não afetação consagrado no dispositivo constitucional

${ }^{150}$ Publicado no Diário da Assembleia do Estado de São Paulo. 15 out. 2008, p. 41.

${ }^{151}$ Para que seja possível uma análise à luz do instituto da vinculação de receitas, será feita uma abstração quanto a este vício formal de legitimação, em cristalina afronta ao artigo 165, III, da Constituição Federal, que concede ao Chefe do Executivo a iniciativa legislativa para assuntos orçamentários. Este é o entendimento consolidado no Supremo Tribunal Federal, consoante se infere da ADI 820-0/RS. Pleno. Rel. Min. Eros Grau. j. 15 mar. 2007. DJU 29 fev. 2008. A ADI 103-5/RO (Pleno. Rel. Min. Sidney Sanches. j. 3 ago. 1995. DJU 8 set. 1995). Nesta esteira, é lembrado que qualquer iniciativa de lei que viole também o artigo 61, $\S 1^{\circ}$, inciso II, "b" c/c artigo 25 (no caso dos Estados) padecerá igualmente da mácula da inconstitucionalidade formal de iniciativa legislativa.

${ }^{152}$ Depreende-se esta intenção da própria ementa: "Dispõe sobre a destinação de $\mathrm{R} \$ 0,25$ (vinte e cinco centavos) em cada tarifa paga nas praças de pedágio das empresas que administram rodovias, diretamente ou por meio de concessão, para a Secretaria de Segurança Pública do Estado de São Paulo, especificamente aos agentes da Polícia Militar, Polícia Civil, Corpo de Bombeiros e Agentes Penitenciários."

${ }^{153}$ Artigo $1^{\circ}$ - Ficam destinados $\mathrm{R} \$ 0,25$ (vinte e cinco centavos) em cada tarifa paga nas praças de pedágio das empresas que administram rodovias, diretamente ou por meio de concessão, para a Secretaria de Segurança Pública do Estado de São Paulo, especificamente aos agentes da Polícia Militar, Polícia Civil, Corpo de Bombeiros e Agentes Penitenciários.

$\S 1^{\circ}$ - As finalidades para as quais se destina o disposto no caput referem-se a complementações salariais e pagamentos de gratificações, treinamento de pessoal, investimentos em tecnologia e reequipagem.

(...)

Artigo $2^{\circ}$ - As empresas concessionárias que operam as praças de pedágio, o DER - Departamento Estadual de Rodagem e, o DERSA - Desenvolvimento Rodoviário S/A, devem recolher o valor referido no artigo anterior aos cofres da Secretaria de Estado da Fazenda, sob código de arrecadação próprio.

(...) 
citado não serve, por si só, para vedar a vinculação de receitas que não a de impostos a um determinado Poder, conforme se depreende da análise da Medida Cautelar em Ação Direta de Inconstitucionalidade $\mathrm{n}^{\circ}$ 659-2/GO.

Nesta assentada, a Corte manifestou-se no sentido de que ao se vincular determinado percentual a certo Poder - in casu, o Legislativo -, estar-se-ia ferindo as disposições orçamentárias formais contidas nos artigos 163 a 169 da Carta, e não o artigo 167, IV em si, visto que este se aplica, tão somente, à vinculação de impostos ${ }^{154}$. Esta perspectiva formal também foi abordada na decisão liminar na Ação Direta de Inconstitucionalidade $2.447-7 / \mathrm{MG}^{155}$, cuja argumentação cingiu-se na supressão da iniciativa do Executivo, dado que a vinculação do artigo 167, IV, abordada na inicial, não se coadunaria no caso, que estipulava a vinculação da recente corrente líquida do Estado.

Com supedâneo nestas considerações, pode-se dizer que, no caso da autarquia rodoviária, há a utilização do redirecionamento de receitas de um ente da Administração a outro, constituindo-se em verdadeira quebra à autonomia financeira que também gozam estas instituições.

Há, ainda, um agravante sob o viés do direito administrativo no tocante à autonomia administrativa $^{156}$ das empresas estatais, a saber, as sociedades de economia mista e as empresas públicas. E não é demais recordar que um ente só poderá ser autônomo se gozar de suficiência financeira, conforme supramencionado por ALFREDO AUGUSTO BECKER $^{157}$. Por esta razão é que JOSÉ MAURICIO CONTI ${ }^{158}$ cogita que, para uma autonomia financeira do Poder Judiciário mais saliente, sejam realizadas novas vinculações constitucionais ou legais (neste último caso, com o respeito às ressalvas constitucionais) a fim de lhe garantir autonomia com relação aos outros dois Poderes.

\footnotetext{
${ }^{154}$ ADI-MC 659-2/GO. Pleno. Rel. Min. Carlos Velloso. j. 7 ago. 1992. DJU 11 set. 1992, p. 142-43. Ver também item 3.3 infra quanto à abrangência do princípio da não vinculação.

155 Pleno. Rel. Min. Joaquim Barbosa. j. 4 mar. 2009. DJU 17 mar. 2009. No caso em testilha, a impossibilidade de comprovação de que a vinculação havia sido somente da receita de impostos era inviável, dado o pequeno percentual estabelecido na vinculação. Ademais, ficou ressaltado que os percentuais estabelecidos no artigo 212 como "vinculação" à "manutenção e desenvolvimento do ensino" do artigo 167, IV, é pautado pelo mínimo, e não pelo máximo.

${ }^{156}$ Cf. GAudEMET, Yves. Droit administratif. 18. ed. Paris: L.G.D.J., 2005, p. 198. O autor ressalta que, como corolário do princípio da autonomia, a descentralização administrativa mitiga a força do poder central, de forma que tal ideia pode ser aplicada nas relações interfederativas.

${ }^{157}$ Teoria..., p. 349.

${ }^{158}$ A autonomia..., p. 148.
} 
Apenas para menção e exemplificação, na Espanha a Constituição de 1978 estabelece dois princípios financeiros basilares: o da autonomia e suficiência financeira ${ }^{159}$, que garante com que os entes locais possam definir sua própria forma de despesa e uso de seus recursos públicos ${ }^{160}$. Tal fator destaca a capacidade destes entes em reger os interesses de seus munícipes sem a interferência substancial de outro ente da federação ${ }^{161}$. Nas palavras de HORACIO GUILLERMO CORTI ${ }^{162}$ :

\begin{abstract}
Segundo este princípio geral, os recursos financeiros que dispõe uma unidade política e, em geral, qualquer órgão estatal, devem ser suficientes para sustentar os gastos públicos ligados às funções jurídicas que o próprio ordenamento jurídico impõe àquele órgão ou unidade política. A suficiência é uma exigência cujo objetivo consiste em assegurar a coerência entre as normas que regulam os fins das autoridades públicas e as normas que estabelecem os meios para que estas autoridades atuem. (destacou-se)
\end{abstract}

Na criação das estatais que exerçam atividade econômica, elas aparecem como um ente despersonalizado com certa autonomia do ente central instituidor, já que os recursos auferidos não são repassados ao orçamento do respectivo ente federativo, semelhantemente quando há empresas mistas criadas pelo poder público, especificamente para a prestação de um serviço público ${ }^{163}$. Logo, conclui-se que o redirecionamento de receitas é prática atentatória a essa autonomia.

É oportuno, no entanto, lembrar a lição de JOSÉ MAURICIO CONTI ${ }^{164}$ ao consagrar que "o orçamento público é único para cada uma das Administrações Públicas (federal, estaduais, distrital e municipais), e nele estão previstas as receitas e as despesas de todos os órgãos que as compõe". Desta forma, apesar de os recursos não adentrarem na massa única do orçamento geral, em consagração ao princípio da unidade as verbas destas estatais de

159 Cf. ReguerA, Emilia Girón. La financiación autonómica del sistema constitucional español. Cádiz: Universidad, Servicio de Publicaciones, 2003, p. 130. Neste país, o financiamento autônomo é oriundo da garantia de meios tributários e financeiros para fazer frente aos gastos públicos.

${ }^{160} \mathrm{Cf}$. GRIJALBA, Miguel Angoitia. Il financiamento degli enti locali in Spagna. Rivista di Diritto Finanziario e Scienza delle Finanze. Milano. v.62. n.4. dic. 2003, p. 499: "Por autonomia podemos entender como o direito da autoridade local de decidir sobre as matérias de interesse aos seus cidadãos, sem nenhum controle de outros níveis de governo e sob a sua responsabilidade. Na sua acepção financeira, a autonomia se sintetiza como a capacidade dos entes locais de:

- fixar, de forma independente e sob a sua própria responsabilidade, a sua quantidade de despesa;

- escolher os recursos com os quais financiar aquela despesa;

- estabelecer a distribuição dos recursos e das despesas entre os cidadãos-contribuintes;

- separar temporalmente despesas e recursos."

161 Cf. SERRANO, Luís Sánchez. Tratado de derecho financiero y tributario constitucional. t. I. Madrid: Marcial Pons, 1997, p. 289-90. O autor explica que a autonomia financeira local é nada mais que a concreção, pelo Direito Financeiro, da autonomia concedida constitucionalmente a estes entes. Além do mais, são eles que possuem maior proximidade com os cidadãos, com maiores chances de contato com os problemas locais.

${ }^{162}$ Derecho constitucional..., p. 97 e ss.

${ }^{163}$ Cf. BAndeira de Mello, Celso Antônio. Curso..., p. 199-200.

${ }^{164}$ A autonomia..., p. 33. 
capital inteiramente público devem ser considerados contabilmente em conjunto com o orçamento do ente federativo ${ }^{165}$.

\subsection{TIPOLOGIA E CLASSIFICAÇÃO DAS VINCULAÇÕES}

Após ser delineado o caráter das vinculações (econômico, jurídico e político), bem como ser ressaltado que os critérios temporais na arrecadação não influem em sua característica, deve-se avaliar que as vinculações podem ser classificadas quanto ao seu efeito e funções.

JosÉ MARTINHO SIMÕEs ${ }^{166}$ entende que as consignações de receitas possuem quatro funções: a) conceder maior reforço ao crédito público, b) limitar o montante de uma despesa ou receita, c) afetar uma receita temporária a uma operação determinada d) garantir um serviço que se queira personalizar com patrimônio próprio (ou seja, custear por taxa). JАСOB WILNER SUNDELSON ${ }^{167}$ também verifica as características "a" e "b", adicionando que há a possibilidade de se vincular receitas especiais de emergência para propósitos específicos, bem como utilizar o tributo para fins não fiscais, que seria a extrafiscalidade ou parafiscalidade. $\mathrm{Na}$ esteira destes e outros autores, intentaremos oportunamente propor uma classificação própria das funções das vinculações.

Quanto aos seus efeitos, dependerá de como a afetação é concebida: como um instrumento forte ou débil, de ampla ou estreita abrangência. Ver-se-á, neste quesito, a classificação exposta pela doutrina.

\subsubsection{CLASSIFICAÇAO QUANTO AOS EFEITOS}

MARGARET WILKINSON ${ }^{168}$, ao definir as vinculações no ordenamento britânico, classificou-as em quatro tipos. A despeito de não estar explicitado em sua obra, cremos que tal classificação pautou-se nos efeitos que cada vinculação pode exarar quando da sua instituição. São eles:

\footnotetext{
${ }^{165}$ Ver, com relação a esse ponto, item 3.5.1 infra.

${ }^{166}$ Finanças..., p. 650 e ss.

${ }^{167}$ Budgetary..., p. 262.

${ }^{168}$ Paying..., p. $125-26$.
} 
a) Strong/expenditure-determining (forte): neste caso, a receita do tributo determina a quantidade de gasto existente para o serviço afetado;

b) Weak/information-giving (fraco): não há a determinação do gasto por meio da receita do tributo vinculado; desta forma, transferências complementares oriundas do orçamento geral são possíveis, bem como transferências do excesso da arrecadação deste tributo para o fundo único estatal;

c) Wide (ampla): a receita é destinada para um total de gasto, de forma genérica;

d) Narrow (estreita): a vinculação é feita a fundos com gastos dentro de um programa específico.

No tocante ao primeiro caso - verificado, no ordenamento brasileiro, nos tributos vinculados -, o financista português JOSÉ MARTINHO SIMÕES ${ }^{169}$ também aponta que a consignação pode limitar o montante de uma receita ou de uma despesa. Estabelecer-se-ia que, ao invés de destinar à despesa uma quantia predeterminada, ela seria custeada com os recursos totais de uma receita específica, podendo ou não limitar a respectiva despesa a depender da arrecadação.

O outro viés de consignações deste jaez é quanto à definição de limites a receitas específicas. Se há a vinculação de uma receita a uma despesa individualizada, com a respectiva proibição de tergiversação dos objetivos que ensejaram a sua instituição (e. $g .$, o serviço público que deu origem a esta despesa), não deverá ocorrer uma arrecadação que ultrapasse as despesas. A principal função desta técnica, em sua visão, é evitar com que as autarquias, estatais ou outras entidades da Administração Indireta cobrem taxas assaz superiores ao necessário para o custeio do serviço que lhes foi delegado ${ }^{170}$.

Quanto aos modelos demonstrados, MARGARET WILKINSON ${ }^{171}$ expõe combinações dos tipos "a" e "b" com os "c" e "d" como possíveis na sistemática proposta, como exemplos:

i) $\quad \mathrm{a}+\mathrm{c}$ (vinculação forte e ampla ${ }^{172}$ ): é o que pode ocorrer em despesas com educação, visto que maiores gastos implicam o aumento dos recursos vinculados,

\footnotetext{
${ }^{169}$ Finanças..., p. 652.

${ }^{170}$ Cf. SIMÕES, José Martinho. Finanças..., p. 652.

${ }^{171}$ Paying..., p. 126.

172 Neste caso, MARGARET WiLKINSON (Paying..., p. 128-29) entende que os contribuintes devem revelar as suas preferências no gasto público por meio do voto para a plena efetivação deste tipo de vinculação. Por
} 
e sua economia deverá redundar em redução da carga tributária, e não transferência dos recursos a outros setores;

ii) $\mathrm{a}+\mathrm{d}$ (vinculação forte e estreita): um exemplo deste modelo ocorre na vinculação de tributos sobre combustíveis para expansão rodoviária. Este seria o melhor exemplo de vinculação pela correspondência do benefício com a tributação;

iii) $\quad b+c$ (vinculação fraca e ampla): o sistema de seguridade social britânico é citado como exemplo, por utilizar o programa de benefícios diferidos no tempo em razão da contribuição e necessitar de complementações do orçamento geral.

iv) $\mathrm{b}+\mathrm{d}$ (vinculação fraca e estreita): como, $v . g$., um adicional sobre o imposto de renda para educação na enfermagem, programa este que continuará contando com recursos complementares.

No Brasil, algumas combinações ficam prejudicadas no modelo constitucional traçado em 1988. Existem, sobretudo, vinculações fracas, visto que na maioria dos casos os gastos públicos necessitam ser complementados por recursos gerais do orçamento. As vinculações fortes e estreitas ocorreriam nos tributos vinculados, como taxas e contribuições de melhoria ${ }^{173}$, onde o princípio do benefício na tributação e os mecanismos de preço serviriam para demonstrar a eficiência alocativa nos recursos e gastos ${ }^{174}$. Outro exemplo é na vinculação sobre combustíveis. As vinculações fracas e amplas podem ocorrem na saúde e educação, normalmente "estreitadas" em fundos como no caso do Fundo de Combate e Erradicação da Pobreza.

Neste contexto, cabe também o registro da classificação tipológica proposta por MARCO AurÉLIO GRECO ${ }^{175}$, que abarca somente as contribuições: expõe que o ordenamento jurídico permite três hipóteses de vinculações intrínsecas (ou seja, determinadas já na arrecadação do tributo): gerais, especiais e individuais.

As vinculações gerais delimitam apenas o campo no qual poderão ser instituídos os tributos, ensejando uma ampla margem de discricionariedade ao legislador quando da disposição da receita. As vinculações especiais ocorrem quando, dada a margem de

conta disto, tal tipo de vinculação serviria mais para os bens públicos puros (como defesa nacional) em detrimento dos mistos (educação e transporte público). Porém, a despeito desta conveniência, ressalta a autora (p. 133) que raramente a defesa nacional é utilizada como razão para vinculação, por exemplo.

${ }^{173}$ Cf. WILKInSON, Margaret. Paying.., p. 133. Esta, aliás, seria a modalidade mais apoiada pela doutrina.

${ }^{174} \mathrm{Cf}$. MCCLEARY, William. The earmarking..., p. 85.

175 A destinação dos recursos decorrentes da contribuição de intervenção no domínio econômico. Revista Dialética de Direito Tributário. São Paulo. n.104. maio. 2004, p. 124-26. 
atuação determinada, a Constituição limita parte deste campo que justificaria a instituição do tributo, por sua vez acarretando uma margem restrita de discricionariedade ao legislador. Já nas vinculações individuais, há a destinação expressa pela Constituição do produto da arrecadação, cerrando completamente o talante legislativo com a inexistência de margem de escolha.

Para exemplificar, o autor menciona as contribuições do artigo 149, caput, e 195 da Constituição. As contribuições sociais pertenceriam à categoria das vinculações gerais; as contribuições para a seguridade social, às vinculações especiais; por fim, o artigo 212, § $5^{\circ}$, ao prever o salário-educação, erige uma vinculação individual de recursos públicos.

Por fim, outro exemplo de vinculações especiais pode ser extraído no caso mencionado por FERNANDO FACURY SCAFF ${ }^{176}$, julgado no Supremo Tribunal Federal, referente à arrecadação do PIS e a sua vinculação ao BNDES, no qual fica consignado que a finalidade precípua do tributo é custear a seguridade social, não havendo desvirtuamento na destinação para programas de desenvolvimento econômico (artigo 239 da Constituição Federal). No caso em tela, a Corte dividiu o fenômeno em dois momentos: arrecadação e destinação, não analisando o mérito propriamente dito da ação - que questionava a não aplicação exclusivamente em seguridade social dos $40 \%$ previstos ao BNDES para programas de desenvolvimento econômico. Apesar de no voto não haver a fundamentação sob este prisma, salta aos olhos que se optou por considerar esta vinculação específica do PIS como especial, ao invés de individual - que seria o caso.

\subsubsection{CLASSIFICAÇÃO QUANTO À FUNÇÃO}

Com fulcro no que já foi exarado até então, propomos uma classificação das vinculações quanto à sua função no papel de instrumento jurídico, a fim de analisar as nuances que costumeiramente justificam as vinculações de receitas. Elas serão delineadas, essencialmente, sob a égide da prática pátria. Diante disto, as vinculações podem ser:

\footnotetext{
${ }^{176}$ As contribuições sociais e o princípio da afetação. Revista Dialética de Direito Tributário. São Paulo. n. 98. nov. 2003, p. 53-54. O julgado em comento refere-se aos Embargos de Declaração em Recurso Extraordinário n $\mathrm{n}^{\circ} 217.117 / \mathrm{SP}$.
} 


\section{a) vinculação stricto sensu}

A vinculação de receitas pode servir a diversos escopos. Mas o principal deles é a afetação de uma receita a uma despesa, quer por razões político-sociais ${ }^{177}$, quer por simples conveniência administrativa de se mensurar o montante a custear determinada despesa. Aliás, esta é a definição de JAMES BUCHANAN ${ }^{178}$ para as afetações (earmarkings ou hypothecations): “'afetação' é definida como a prática de designar ou dedicar receita específica para o financiamento de serviços públicos específicos."

Um exemplo cristalino é a afetação sobre os tributos incidentes nos combustíveis, que será brevemente delineada posteriormente ${ }^{179}$, já que ocorre a perfeita relação quid pro quo entre tributo e custeio. Assim, a vinculação aparece, em sentido estrito, com a evidência do elo entre fonte e destino. É nesse sentido que a vinculação stricto sensu ganha forma, retomando a característica do elo normativo existente entre receita e despesa.

\section{b) “vinculação" para o federalismo fiscal}

Conforme pode ser observado, há o uso impróprio das vinculações com o exsurgimento de funções atípicas, em um conceito mais amplo de vinculação de receitas. Uma delas é a chamada vinculação para o federalismo fiscal, estabelecendo percentual de receitas vinculadas destinadas a transferências intergovernamentais, partilhas ou coparticipação tributária. Neste contexto, adentrar-se-iam os coeficientes mínimos estabelecidos para despesas consideradas interfederativas, como saúde e educação. Aparecem, sobretudo, no âmbito constitucional ${ }^{180}$.

Este é, segundo destacado, um conceito mais amplo de vinculação de receitas. Nesta senda, WILLIAM MCCLEARY ${ }^{181}$, ao comentar a tentativa de abolição das vinculações pela Comissão de Gasto Público colombiana, critica a abordagem estrita dada às vinculações de receitas, visto que aquele órgão pautou-se somente nas vinculações pelo

\footnotetext{
177 Cf. FenNel, Lee Anne. Death..., p. 640. O exemplo dado pela autora com as vinculações destinadas às instituições de caridade é salutar, visto que facilitaria a aceitação dos contribuintes. Desta forma, "quanto mais específica a doação, e quanto maior o controle que o doador exerce sobre o gasto, mais a transação é emoldurada como uma contribuição para um bem cognoscível, ao invés do que meramente um dreno nos recursos do doador."

${ }^{178}$ The economics..., p. 457-58.

${ }^{179}$ Ver item 2.1.1 infra.

${ }^{180}$ O vislumbre desta possibilidade é encontrado na obra de WILLIAM MCCLEARY (The earmarking..., p. 82 83). Ver, mais especificamente, item 2.2 infra. Cumpre salientar também a existência de "vinculação" de receitas por instrumentos infraconstitucionais no federalismo fiscal brasileiro. A Lei Complementar $\mathrm{n}^{\circ} 79$, de 1994, ao criar o Fundo Penitenciário Nacional - FUNPEN, institui no seu artigo $3^{\circ}$, $\S 2^{\circ}$, a repartição de $50 \%$ da quantia vinculada da taxa judiciária recolhida em favor da União Federal ao Estado de origem, que é também na fração de 50\%. Ver item 4.1.3.1 infra.

${ }^{181}$ The earmarking..., p. 99-100.
} 
princípio do benefício, desejando permitir somente este tipo de modalidade naquele Estado. Desta forma, não incluiu as "repartições de receita, tributos sobre a folha de salário para a seguridade social, e lucros das empresas públicas, todas estas poderiam ser consideradas vinculações sob uma definição mais ampla." (destacou-se)

O uso das transferências e despesas obrigatórias no federalismo fiscal como vinculações é uma exacerbação de seu uso impróprio, abarcado pela Constituição ao excepcioná-las da regra da não vinculação.

c) vinculação como garantia

A vinculação também pode possuir a função de garantia creditícia entre os entes federativos, ou, ainda, do fiel pagamento aos agentes privados prestadores de serviços públicos - como ocorreu na lei que instituiu as Parcerias Público-Privadas no Brasil. Foi nesta função de vinculação-garantia ${ }^{182}$ que as primeiras afetações apareceram na França, havendo o seu reconhecimento nesta função também por JACOB WILNER SUNDELSON ${ }^{183}$. Aqui, diferentemente do caso anterior, há a manutenção do elo normativo entre fonte (as receitas) e destino (despesa originada pelo inadimplemento estatal com relação a algum débito)

No Brasil, é a modalidade que enseja maiores discussões acerca da constitucionalidade de sua aplicação em alguns casos, principalmente com o advento da Lei de Responsabilidade Fiscal; aumentando o âmbito de aplicação do permissivo contido no artigo $167, \S 4^{\circ}$, a Lei previu a possibilidade de retenção destas receitas vinculadas para autossatisfação de débito pendente para com a União. Sobremais, saliente-se que essas vinculações como garantias são regulamentadas por Resoluções do Senado - mas a sua instituição também depende de lei específica. Há, ademais, uma nova função surgida com a Lei das Parcerias Público-Privadas nas relações do poder público com o agente privado.

\section{d) vinculação como punição ou repressão}

SEBASTIÃo DE SANT'ANNA E SILVA ${ }^{184}$ entende que a vinculação de receitas também pode servir como punição ou repressão a certos atos cujas práticas o governo deseja desestimular, como, v. g., na instituição de impostos sobre bebida ou celibatários e

\footnotetext{
${ }^{182}$ Não há uma expressão doutrinária para vinculação-garantia, sendo uma construção nossa para facilitar a identificação desta função.

${ }^{183}$ Budgetary..., p. 262.

${ }^{184}$ Os princípios..., p. 28.
} 
casais sem filhos para vincular esta receita a tratamentos médicos e destinação dos recursos a famílias numerosas, respectivamente.

Outras vezes, inclusive para justificar a prática de algumas atividades consideradas viciosas, são realizadas as vinculações de receitas oriundas destas atividades a fins nobres, como na vinculação de parcela das receitas das loterias a programas destinados aos indivíduos de baixa renda - o que mitigaria, inclusive, os efeitos negativos de sua regressividade. Isto supostamente fomentaria apoiadores para as loterias, principalmente os combatentes ferrenhos pelo seu banimento. Porém, é demonstrado que, nos Estados Unidos, programas que são financiados por estes recursos têm retração no gasto em comparação ao financiamento geral do orçamento estatal, além de haver a constante tredestinação legal ou constitucional destas receitas a outros programas após o transcurso de determinado período. Não somente isto: estas receitas, por serem extremamente variáveis conforme os anos, provocam grandes vicissitudes $\operatorname{orçamentárias~}^{185}$.

Segundo estes exemplos, a vinculação viria conjuntamente com o caráter extrafiscal de um determinado tributo. Porém, entendemos que não se trataria de uma função da vinculação, mas sim a consagração do efeito tributário da extrafiscalidade. Aqui, o legislador deseja condicionar determinadas condutas por meio de tributação desestimuladora de certas práticas. Assim, o mero fato de haver um imposto sobre casais sem filhos já influenciaria o comportamento dos indivíduos, pouco importando se essa receita é vinculada a famílias numerosas, construção de escolas ou, até mesmo, algo mais distante da relação do tributo, como para segurança pública. Mas a vinculação, em si, não será repressiva.

Esta prática poderia se dar também por meio de fundos sancionatórios federativos, consoante estudado por ALBERTO DE ROVIRA MOLA ${ }^{186}$, haja vista a possibilidade de existir

\footnotetext{
${ }^{185}$ Cf. RYCHLAK, Ronald J. Lotteries, revenues and social costs: a historical examination of state-sponsored gambling. Boston College Law Review. v. 34. dec. 1992, p. 51-54. Porém, o jurista conclui que as loterias efetivamente cumprem o escopo de levantar fundos sem que haja tributação, apesar dos problemas orçamentários que a sua vinculação, a regressividade e a oscilação na arrecadação costumam acarretar. Cf. também ANESI, Vincent. Earmarking..., p. 682. Como exemplo, este autor ressalta que todos os estados australianos vinculam parcela da tributação sobre os jogos para programas de saúde ou programas voltados à contenção dos problemas ligados ao jogo.

${ }^{186}$ Los fondos fiscales con finalidad redistributiva. Madrid: Inst de Estudios de Administración Local, 1976, p. 210. Extrapolando o âmbito de análise das vinculações, entendemos que a existência deste tipo de fundo acaba transcendendo a punição dos maus governantes à população respectiva, razão pela qual não recomendamos o acolhimento desta proposta em nosso ordenamento. Por outro lado, fundos estimuladores também apontados pelo jurista - serviriam para premiar a boa gestão e aplicação dos recursos por meio de "condutas desejadas pelo ordenamento jurídico", utilizando-se índices de aumento recompensatórios. Quanto
} 
índices que corrijam a má-utilização dos recursos transferidos, diminuindo a participação do ente nestas receitas.

\section{e) vinculação compensatória}

É possível identificar, também, uma vinculação com função compensatória. Esta modalidade é observável, sobretudo, na seara ambiental, para se compensar eventuais perdas financeiras na prática do chamado desenvolvimento sustentável dos países, além de desestimular o rent-seeking nos tributos ambientais, conforme demonstrado por CRAIG BRETT e MiCHAEL KEEN ${ }^{187}$. Estas compensações fiscais ${ }^{188}$ também podem servir para se evitar o efeito not in my backyard ${ }^{189}$ - não se confundindo com o sistema de compensação financeira ocorrido na Alemanha, “(...) cuja finalidade é evitar que as diferenças quanto à capacidade financeira das entidades descentralizadas leve à falta de uniformidade nas condições de vida dos cidadãos."

RICHARD STEWART ${ }^{191}$ exemplifica com a vinculação de parte da receita auferida na tributação sobre a emissão de gases de efeito estufa a fim de haver a transferência aos países menos desenvolvidos, fomentando, destarte, a redução da emissão destes gases com a respectiva compensação financeira pelo não aproveitamento pleno de seus recursos naturais. Outro exemplo trazido por LAURA MARSILIANI e THOMAS RENSTRÖM ${ }^{192}$ é com a vinculação das receitas japonesas obtidas sobre a tributação na emissão de gases como compensação às vítimas da poluição.

a estes fundos, somos inclinados a considerar como mais recomendáveis em nosso sistema de federalismo fiscal.

${ }^{187}$ Political uncertainty and the earmarking of environmental taxes. Journal of Public Economics. v. 75. 2000, p. 317. Como a vinculação para programas ambientais reduz a discricionariedade dos governantes, aumenta-se a credibilidade destas despesas e a certeza de que as receitas serão aplicadas para o fim colimado ao invés de serem desvirtuadas pelos governantes.

${ }_{188}$ Cf. ConTI, José Mauricio. Federalismo fiscal e fundos de participação. São Paulo: Juarez de Oliveira, 2001, p. 28-29. O princípio da compensação fiscal, corolário dos fundamentos sócio-econômicos do federalismo fiscal, pode ser uma maneira de se compensar determinados efeitos que um ente subnacional venha a sofrer. Uma externalidade negativa - restrição ou limitação de uso de determinado bem, como medidas preventivas ambientais obrigatórias - também pode ser alvo deste tipo de compensação. Contudo, a legislação tributária pátria, por vezes, não prevê estas compensações, o que se pode depreender em aresto do Superior Tribunal de Justiça (Recurso Especial n ${ }^{\circ}$ 811.712/SP. $2^{a}$ Turma. Rel. Min. Castro Meira. j. 2 jun. 2009. DJU 12 jun. 2009) onde se discutia o repasse de verba de ICMS para município que abrigava uma usina hidrelétrica, mas cuja distribuição - local de saída da mercadoria - ocorria em município vizinho.

${ }^{189}$ Cf. MENDES, Marcos. Federalismo..., p. 428-29. Ocorre quando um serviço público, apesar de gerar benefícios gerais, traz consigo determinados inconvenientes, como ocorre na construção de presídios em um determinado município, ou a instalação de uma usina nuclear ou aterro sanitário. Neste caso, o economista brasileiro aponta que o remédio adotado pelos governantes locais é a sobretaxação ou tentativa de proibição desta atividade.

${ }^{190}$ Cf. ConTI, José Mauricio. Federalismo..., p. 51.

${ }^{191}$ Environmental Regulation and International Competitiveness. The Yale Law Journal. v. 102. 1993, p. 2104.

${ }^{192}$ Time inconsistency..., p. C123. 
José MARCos Domingues De OliveIRA ${ }^{193}$ defende a vinculação de receitas para fins de incentivos às políticas públicas voltadas ao meio ambiente. Propõe, inclusive, a utilização de incentivos fiscais nos tributos já existentes, por meio de alteração constitucional para promover esta medida:

Ora, no Brasil, os impostos sobre a produção e o consumo podem ser amplamente
utilizados como instrumento de tributação ambiental, através de um sistema de
graduações de alíquotas, isenções e restituições conforme a natureza dos produtos ou
mercadorias. O imposto de transmissão e o imposto de renda podem ser adequadamente
combinados através de isenções e reduções de alíquotas ou da utilização do valor do
primeiro como crédito contra o que for devido a título do segundo, estimulando-se,
assim, doações para fins de preservação ambiental. Também os impostos sobre a
propriedade imóvel prestam-se à criação de incentivos à preservação quando conjugada
com a utilização dos bens de que se trata, estabelecendo-se, por exemplo, alíquotas
inferiores às comuns no caso de o proprietário proceder à preservação de parte da gleba,
que tenha interesse ecológico, e desde que dê utilização intensiva ao solo agricultável
remanescente. (destacou-se)

Ocorre que, sem menoscabo à louvável iniciativa do jurista, a proteção ao meio ambiente não pode se verificar na forma como vem proposta, pelo menos não por meio de impostos. Talvez por taxa, por ser este um tributo vinculado à atividade estatal específica, prática esta verificada em outros países, conforme ponderado pelo próprio autor, e, aliás, como utilizado aqui no Brasil em alguns casos ${ }^{194}$.

Isto porque, no tocante aos impostos, não há como prosperar a concepção de concessão de benefícios físcais com a respectiva vinculação destes recursos a determinado fim. O poder público abdicaria de parcela da arrecadação desses impostos em troca de investimentos, realizados pelo contribuinte, em uma determinada política pública. Tal procedimento pode ser alvo de diversas fraudes, visto a dificuldade operacional de controle e verificação, pelo poder público, do cumprimento das efetivas condições. Além do mais, esta modalidade de vinculação indireta não tem sido acolhida no Supremo Tribunal Federal $^{195}$, razão pela qual tal instrumento só poderia surgir por via de exceção, ou seja, emenda constitucional que ressalve a abrangência do artigo 167, IV, da Constituição.

Propostas de vinculações ecológicas vêm ganhando fôlego com a introdução do artigo 146-A na Constituição Federal, por meio da Emenda Complementar nº 42, de 2003. Tramita na Câmara dos Deputados, inclusive, Projeto de Lei Complementar ( $n^{\circ} 494$, de 2009) a fim de regulamentar este dispositivo constitucional, com o escopo de conceder

\footnotetext{
193 Meio-ambiente..., p. 86-87. Tal hipótese foi também analisada por STEWART STERK (Environmental Review in the Land Use Process: New York's Experience with SEQRA. Cardozo Law Review. v. 13. 199192, p. 2093, nt. 175.

${ }^{194}$ Cf. OliveIRA, José Marcos Domingues de. Meio-ambiente..., p. 87.

${ }^{195}$ Ver item 2.1.2 infra.
} 
incentivos tributários para as empresas consideradas "ecológicas" e com tecnologias que diminuam o dano da atividade ao meio ambiente. $\mathrm{O}$ artigo 23 do Projeto, inclusive, propõe uma vinculação temporária de $25 \%$ dos recursos orçamentários federais utilizados anualmente para fomentar o desenvolvimento científico e tecnológico com relação às energias "limpas" e fontes sustentáveis. Contudo, evidentemente esta afetação não poderá ser de recursos oriundos de impostos, sob pena de infringência do disposto no artigo 167, IV, da Constituição Federal.

\subsection{O TRADE-OFF DA VINCULAÇÃO DE RECEITAS}

Como instrumento jurídico-econômico, a vinculação é alvo de constantes aplausos e críticas por parte da doutrina. Entretanto, o que se pode depreender é que seus benefícios ou malefícios são relativos e dependem do ponto de partida adotado para a sua análise. Uma vinculação "boa" para um Estado pode ser "ruim" para outro, ou, então, pode transformar-se de "boa" para "ruim" com o passar dos tempos. Igualmente, grau e intensidade de seu uso também são relativos, visto que pode ser benéfico, ou não (regra geral), para um país ter quase todas as suas receitas vinculadas.

SUSANNAH CAMIC ${ }^{196}$, por exemplo, demonstra algumas vantagens procedimentais nas constrições orçamentárias trazidas pelas vinculações nos Estados Unidos. WILLIAM MCCLEARY ${ }^{197}$, igualmente, ressalta que as mesmas justificativas usadas pelos críticos são comumente utilizadas pelos defensores, como a rigidez, a limitação na realocação dos recursos e a automaticidade das vinculações, o que pode auxiliar no combate à corrupção de governos espúrios. Ademais, costuma-se afirmar que a flexibilidade aparece como uma ilusão orçamentária, dado que algumas despesas, como gastos com pessoal, segurança e seguridade pessoal acabam possuindo vida própria uma vez iniciadas, de forma que impede esta suposta possibilidade de mudança de recursos de um programa para outro conforme apregoado pela doutrina contrária às afetações.

\footnotetext{
${ }^{196}$ Earmarking..., p. 57-58. A saber, quatro são as vantagens levantadas por ERIC PATASHNIK mencionadas pela autora: (i) a alocação dos recursos aparece vinculada aos trust funds, que tem a possibilidade de acumular recursos; (ii) concessão de status extraorçamentário das receitas vinculadas; (iii) as receitas vinculadas ficam sob um automatismo no gasto; (iv) a supervisão dos comitês dá-se tanto na coleta quanto no gasto das receitas.

${ }^{197}$ The earmarking..., p. 84.
} 
Um exemplo empírico que externa o trade-off existente é a constatação de KEYoung CHU e JoHn NORREGAARD ${ }^{198}$ dos prós e contras das vinculações na Coréia do Sul:

Enquanto que a vinculação (earmarking) tem seus méritos (por exemplo, protegendo certos programas contra a alocação arbitrária de recursos e instabilidade na provisão de serviços), seu uso extensivo na Coreia - para transporte, construção de rodovias, e educação - pode resultar em desvantagens, como não adaptação das políticas às necessidades locais e rigidez excessiva no suprimento de serviços. Além do mais, as vinculações reduzem a responsabilidade (accountability) política das assembleias eleitas, dado que o orçamento que eles aprovam pode corresponder somente a uma fração limitada dos serviços que são providos aos cidadãos.

Os prós e contras das vinculações, portanto, dependem das premissas adotadas pelo intérprete, o que também dependerá, sobremaneira, da realidade fática verificada em determinado país ${ }^{199}$. Esta é a posição que deve ser adotada no estudo das vinculações de receitas: ao invés de promover a ineficiência e engessamento da gestão orçamentária (críticos) ou aumentar o benefício de determinada tributação e o controle dos gastos públicos (defensores), o que deve ser primordialmente considerado é que grupos de interesse beneficiados tentam capturar o máximo possível do conjunto de externalidades positivas advindas dos recursos público ${ }^{200}$. E as vinculações aparecem na forma de instrumentos utilizados para a defesa destes interesses específicos, e não como algo "bom" ou "ruim" imanente à sua natureza.

WILliam MCCLEARY ${ }^{201}$ demonstra os novos matizes dados ao estudo das vinculações ao se abandonar a questão da vontade única e começar a considerar as imperfeições das finanças públicas na busca por atender os interesses de diversos grupos segregados. Desta forma, as vinculações “acomodariam” estas preferências díspares; sob a luz destes argumentos, o autor conclui pela existência de desvantagens no financiamento por fundo único estatal, pois em sua ótica as decisões coletivas seriam o reflexo das preferências individuais constitucionalizadas, o que legitimaria as vinculações. ROBERT $\mathrm{MGGEE}^{202}$, sob o aspecto sócio-econômico, prega que os países em desenvolvimento devem vincular seus tributos, em detrimento de mantê-los em uma massa única, visto a garantia existente de que haverá, de fato, o gasto no programa pretendido.

\footnotetext{
198 Korea. In: TER-MinASSIAN, Teresa. (ed.). Fiscal federalism in theory and practice. Washington: International Monetary Fund, 1997, p. 560.

${ }^{199}$ Ver a lista elaborada por WILLIAM MCCLEARY (The earmarking..., p. 102) para verificar quando uma vinculação pode ser benéfica a um país sob o ponto de vista econômico.

${ }^{200}$ Cf. MARSILIANI, Laura; RENSTRÖM, Thomas I. Time inconsistency..., p. C123 e nt. 1.

${ }^{201}$ The earmarking..., p. 86.

${ }^{202}$ Principles of Taxation for Emerging Economies: Lessons from the U.S. Experience. Dickinson Journal of International Law. v. 12. 1993-94, p. 93.
} 
Este seria, então, o trade-off principal das vinculações, ao envolver flexibilidade no orçamento e controle na alocação dos recursos segundo os diversos interesses políticos envolvidos. Traçar-se-á, portanto, alguns argumentos justificadores e repressores à sua existência, e também como os autores lidam com o trade-off e com a preferência, ou não, pelas vinculações ${ }^{203}$.

\subsubsection{CRÍTICAS À SUA EXISTÊNCIA: A FALTA DE FLEXIBILIDADE}

A chamada posição ortodoxa ou tradicional das finanças públicas entende que o gasto público deve ser guiado pelas decisões políticas, e não pelas rendas geradas por um tributo vinculado, dado que a vinculação prejudica a flexibilidade do sistema fiscal e da livre alocação realizada pelo Parlamento ${ }^{204}$, transformando-a em um automatismo ${ }^{205}$.

Quanto aos aspectos econômicos de sua existência, a doutrina econômica costuma elencar algumas desvantagens na utilização de vinculações de receitas, o que faz com que a positivação do princípio da não afetação ganhe força nos ordenamentos. São elas: (i) distorções nas escolhas e alocações públicas; (ii) inadequação à dinâmica orçamentária; (iii) comprometimento do papel do orçamento como instrumento de política fiscal; (iv) o custo direto de uma vinculação; (v) perda da qualidade do sistema tributário; (vi) produção de efeitos restritivos à formação de poupança pública; (vii) geração de esforço físcal assimétrico entre órgãos do governo; e (viii) efeitos adversos das vinculações sobre a geração de incentivos econômicos orientados a obtenção de resultados ${ }^{206}$.

Muitos dos argumentos repetem-se na seara jurídica, merecendo destaque alguns destes itens. No tocante ao item (v), em caso de excessivas vinculações, há uma decorrência lógica de maior complexidade ao sistema tributário, no qual deve imperar a

\footnotetext{
${ }^{203}$ É curioso observar - e isto estará bem delimitado no texto a seguir - que os autores, em regra, levantam um efeito da vinculação juntamente com a exposição dos prós e contras, porém, na maioria das vezes concluindo pela vedação da utilização das vinculações.

${ }^{204}$ Cf. explicação de WILKInSON, Margaret. Paying..., p. 122 e CAMIC, Susannah. Earmarking..., p. 57.

205 Cf. Franco, Gustavo. Vinculações. [s.1.]: 2000. Disponível em: <http://www.econ.pucrio.br/gfranco/a76.htm>. Acesso em: 16 out. 2008: “A vinculação consiste em estabelecer um automatismo, ou seja, em comprometer para um certo fim um percentual das receitas de certo imposto (ou contribuição), ou conjunto de impostos, ou mesmo a totalidade de um imposto."

${ }^{206}$ Cf. a listagem destes argumentos em SiLVA, Mauro Alves. Vinculações..., p. 3.
} 
simplificação ${ }^{207}$. Já quanto ao item (vi), as vinculações funcionariam como "gatilhos de despesa" para a arrecadação, ainda que superavitária ${ }^{208}$.

Outras pesadas críticas às vinculações são levantadas pela doutrina: (i) dificulta o controle legislativo; (ii) reduz a flexibilidade no gerenciamento das receitas; e (iii) mina o poder e a discricionariedade do Executivo e Legislativo ${ }^{209}$. WILliam MCCLEARY 210 adiciona a estas características, ainda, a (i) dificuldade no controle orçamentário, dependendo de como estas vinculações estejam operacionalizadas (constitucional ou legalmente); (ii) a extrema rigidez causada no sistema orçamentário, e (iii) a necessidade de revisões periódicas a fim de se verificar se as vinculações têm sido efetivamente cumpridas.

Neste contexto, a vinculação de receitas constituir-se-ia em verdadeira arma de dois gumes: pode ser benéfica ao Legislativo, prejudicando a livre destinação dos recursos quando da elaboração do projeto de lei orçamentária pelo Poder Executivo ${ }^{211}$. No entanto, o revés é que reduziria a própria liberdade do legislador, conforme destacado algures ${ }^{212}$, dado que uma vinculação constitucional restringe o âmbito de atuação dos legisladores ordinários e constitucional derivado (caso se trate de uma cláusula pétrea). Mas, por fim, a restrição impor-se-ia, em última instância, ao administrador público.

Outra visão é que, com a afetação de um novo imposto a uma despesa popular, $v$. g., com facilidade poderia haver a formação do consentimento entre os parlamentares como ao instituir um imposto sobre o álcool com a respectiva destinação dos recursos à saúde, constituindo instrumento de pressão do Executivo sobre o Parlamento ${ }^{213}$. Porém, o que ocorre nas vinculações é, sobretudo, a pressão do Legislativo sobre o Executivo. Esse tipo de pressão, contudo, pode ocorrer em caso de uma afetação por medida provisória, pois ela só começaria a viger após a conversão em lei pelo Legislativo, respeitados os

\footnotetext{
207 Cf., mais detalhadamente, nosso Racionalidade na alocação dos recursos públicos e o princípio da coerência no sistema tributário brasileiro. Revista Jurídica Tributária. v. 5. abr./ jun. 2009, p. 241 e ss.

${ }^{208}$ Cf. Silva, Mauro Alves. Vinculações..., p. 3-4.

${ }^{209}$ Cf. AleXANDER, Frank. Financing..., p. 382, nt. 117, com base nos diversos estudos de RonALD SNELL.

${ }^{210}$ The earmarking..., p. 84.

${ }^{211}$ Cf. CATÃo, Marcos André Vinhas. Novas perspectivas no princípio da não-afetação e destinação da receita tributária. In: PIRES, Adilson Rodrigues; TôRRES, Heleno Taveira (org.). Princípios de direito financeiro e tributário. Rio de Janeiro: Renovar, 2006, p. 581. Em suas conclusões, o autor entende que a não afetação era um postulado que garantia maior liberdade de escolha pelo Executivo. Este caráter não teria sentido no fenômeno da constitucionalização das finanças públicas, donde se infere a maior participação do Legislativo na feitura orçamentária, o que pode redundar em prioridades eleitas pela própria sociedade por meio das vinculações.

${ }^{212}$ Ver item 1.2, "e", supra.

${ }^{213}$ Cf. PAYSANT, André. Finances publiques. 2. ed. Paris: Masson, 1988, p. 6.
} 
ditames do artigo 62, $\S 2^{\circ}$, da Constituição Federal. Nesse caso, poder-se-ia conceber como uma ferramenta de pressão do Executivo.

A doutrina mais moderna entende que a afetação de despesas, como técnica orçamentária, é considerada um procedimento que tende à regressão. Porém, quando o assunto é política orçamentária, é vista com bons olhos tanto pelo Parlamento como pelo Executivo, principalmente para o custeio de despesas novas ${ }^{214}$. Diante disto, é difícil identificar verdadeiramente qual Poder se beneficia mais deste instrumento.

Quanto aos argumentos de que a vinculação fomentaria maior controle dos gastos, eles costumam ser rechaçados com base em questões de eficiência. Nesta esteira de racionalização das despesas públicas, já ensinava AMARO CAVALCANTI ${ }^{215}$ que: $^{-}$

Haveria grande erro em despender muito, ou sem a devida proporção, com o serviço $A$ (obras públicas, por exemplo), e desatender no todo ou fazê-lo de maneira insuficiente, aos serviços $B, C, D, E$, etc. (destaques do original)

Este caráter dúplice é a grande crítica à existência das vinculações de receitas. A mesma manus que supostamente permitiria o maior controle do gasto de receitas pelo povo impede que, em determinadas ocasiões, haja uma gestão racionalizada dos recursos públicos.

MANUEL DE JUANO ${ }^{216}$ relata hipótese em que a afetação possa fazer frente a uma necessidade imediata do Estado ou, então, a um serviço que deva ser executado em caráter improrrogável. Porém, esta mesma indispensabilidade que é usada para subsidiar a afetação é rechaçada pela concepção de que todas as despesas justificam-se, justamente, pela necessidade, cuja igualdade entre elas deveria impedir o estabelecimento de vantagens - tal como a vinculação de determinada receita ${ }^{217}$.

FERNAND BAUDHUIN ${ }^{218}$, igualmente, explica que a consignação de receitas é hostilizada por conduzir a uma gestão criticável dos recursos, utilizando como exemplo a construção de um imóvel "megalomaníaco" pelo Instituto Nacional Belga de Radiodifusão com receitas vinculadas. Ademais, dificulta a fiscalização pelo Parlamento, dado que a prestação destas contas passa despercebida. E, por fim, a afetação, ainda que para fins sociais considerados louváveis, prejudica a política financeira governamental, uma vez que esta não consegue adaptar-se às circunstâncias atuais. Isto porque a ideia inicial de facilitar

\footnotetext{
${ }^{214}$ Cf. Trotabas, Louis. Finances..., p. 145-46.

${ }^{215}$ Elementos de finanças: (estudo theorico:pratico). Rio de Janeiro: Imprensa nacional, 1896, p. 55.

${ }^{216}$ Curso de finanzas y derecho tributario. t. III. Rosario: Molachino, 1964, p. 392.

${ }^{217}$ Cf. Trotabas, Louis. Finances..., p. 143-44.

${ }^{218}$ Précis..., p. 41-42.
} 
o cálculo dos recursos para estas atividades pode ter o efeito reverso com a evolução econômica, em razão de os recursos necessitarem de complementação, se insuficientes, ou entesouramento, se excessivos, já que ficariam destacados do orçamento geral.

Outro problema é que, por vezes, são estabelecidas afetações sem ligação nenhuma com o tributo vinculado, o que dificulta a sua justificativa, bem como rui qualquer tentativa de se estabelecer uma lógica na arrecadação das receitas públicas ${ }^{219}$ e a correlação econômica do princípio do benefício na tributação.

Apesar de tradicionalmente combatida pela doutrina clássica, as vinculações são, hodiernamente, cada vez mais numerosas, o que enseja diversos questionamentos da doutrina moderna ${ }^{220}$. Vejamos o porquê de sua proliferação, com os subsídios dados por esta literatura mais recente.

\subsubsection{RAZÕES À SUA EXISTÊNCIA: O MAIOR CONTROLE DOS GASTOS PÚBLICOS}

A concepção de que as vinculações eram um flagelo orçamentário é oriunda dos ideários da Revolução Francesa, tendo em vista o desenvolvimento do sistema orçamentário francês para a consagração da ideia de que a regra geral é que as receitas não devem ser vinculadas.

Com a evolução das finanças públicas, José MAURICIO CONTI ${ }^{221}$ expõe a corrente que prega pela incumbência à sociedade das decisões políticas de escolher "o tipo, qualidade e quantidade de serviço que deseja ter, bem como a forma pela qual será financiado", cabendo ao Estado, por meios democráticos - como o voto - garantir o seu pleno exercício. Este processo político de decisões sobre questões econômicas é o que se costumou chamar, conforme ressaltou o jurista, de public choice theories.

Desta forma, diferentemente das críticas expostas algures, a escola da escolha pública entende que o crescimento estatal atual advém não das necessidades dos cidadãos, mas sim como imposição da própria burocracia governamental. Assim, alguns mecanismos

\footnotetext{
${ }^{219}$ Cf. JuANO, Manuel de. Curso..., p. 392. O autor utiliza um exemplo no qual a vinculação não possui, em tese, nenhuma relação com o tributo cobrado e a receita arrecadada: na Islândia, em 1954, houve a afetação de $100 \%$ de um imposto cobrado pela importação de automóveis cuja arrecadação serviu como auxílio à indústria pesqueira.

${ }^{220}$ Cf. esta indagação em ANESI, Vincent. Earmarked..., p. 680.

${ }^{221}$ A autonomia..., p. 139-40.
} 
concedem maiores poderes aos contribuintes-cidadãos, como a vinculação de receitas ${ }^{222}$, ressaltando a importância das despesas e receitas serem observadas sob ângulos diversos, mas como uma entidade única, cujo liame seria essencial para a eficiência na alocação dos $\operatorname{recursos}^{223}$.

Esta concepção transmudou-se, ainda, para uma visão heterodoxa das vinculações, considerando que a centralização das receitas é um procedimento que dificulta o controle e a responsabilização nos gastos públicos, incompatível com a atual sociedade dinâmica e consumeirista de bens públicos. Para tanto, é necessário tomar como base a eterna desconfiança estatal - oriunda, segundo a doutrina, do liberalismo Jeffersoniano, do pensamento católico e dos grupos de proteção ambiental -, o que levaria a uma proposta de reconexão dos tributos e serviços públicos por meio das vinculações. Desta forma, o cidadão passa a se tornar o plano principal, superando a concepção de que as decisões devem ser de cima para baixo ${ }^{224}$.

Fomentar-se-ia, desta forma, um maior controle da aplicação dos recursos públicos. De fato, o controle dos gastos públicos vem em confluência ao propósito de se conseguir o máximo de retorno social ${ }^{225}$. Igualmente, a doutrina argentina aceita que a afetação de receitas produz bons resultados em determinados casos (máxime no caso concreto), por imperativo das modernas exigências econômico-sociais. CARLOS GIULIANI FONROUGE $^{226}$ cita como exemplo um imposto sobre as heranças e doações. A afetação desta receita aos gastos de educação primária fez com que houvesse um maior esmero governamental a este setor.

Austen dA Silva OliveirA ${ }^{227}$ demonstra que PAUl AMSElEK e, na mesma vereda, JeAn Pierre TAugourdeau, entendem que uma utilidade extraível da afetação resta perceptível quando se incentiva uma gestão mais rentável e eficaz do Estado. Há também algumas vantagens expostas pela doutrina, como a indução das preferências dos indivíduos, o que facilita melhores decisões quanto ao gasto, sendo este o aspecto positivo das vinculações ${ }^{228}$. Com isto, tem-se como base uma gestão comercial da máquina pública.

\footnotetext{
${ }^{222}$ Cf. WiLkinson, Margaret. Paying..., p. 123.

${ }^{223}$ Cf. MCCLEARY, William. The earmarking..., p. 86.

224 Cf. WILkInson, Margaret. Paying..., p. 124-25. Esta visão é extraída com base em estudos de GEOFF MULGAN, ex-conselheiro do premier inglês Gordon Brown, e ROBIN MURRAY.

${ }^{225}$ Cf. BUEHLER, Alfred Grether. Public finance. 3. ed. New York: McGraw-Hill, 1948, p. 138.

${ }^{226}$ Derecho financiero. v. I. 3. ed. Buenos Aires: Ediciones Depalma, 1977, p. 171.

${ }^{227}$ Aspectos..., p. 81.

${ }^{228}$ Cf. Musgrave, Richard; Musgrave, Peggy. Hacienda ..., p. 340.
} 
Além disso, a doutrina ${ }^{229}$ costuma apontar outras vantagens e justificativas na vinculação de receitas, organizando-as sob diversos aspectos: (i) reforço ao princípio do benefício na tributação; (ii) garantia de que determinados fundos sempre terão recursos; (iii) estabilização das finanças estatais; (iv) facilitação da aprovação popular na instituição ou aumento de um tributo ${ }^{230}$; (v) regularidade dos fluxos de recursos e eficiência econômica do gasto público, (vi) estabilidade do sistema federativo, (vii) descentralização do processo decisório, e (viii) formação de poupança compulsória ${ }^{231}$.

MARGARET WILKINSON ${ }^{232}$ também demonstra que, em estudo realizado na GrãBretanha, a maioria da população considera que despesas para saúde e educação $(90 \%$ e $80 \%$, respectivamente) devem ser muito maiores do que os patamares atuais, ainda que isto implique o aumento de tributos. Cortes em outros gastos, como benefícios no caso de desemprego e despesas à defesa nacional, são considerados necessários. Adicione-se a este contexto que esta grande maioria também entende que paga a quantia correta de tributos ou muito mais do que o necessário. Desta forma, conclui a autora que a vinculação pode fazer com que os tributos para alguns setores sejam menos impopulares do que o usual.

Assim, saúde e educação são considerados, tanto pelos opositores quanto defensores das vinculações, como setores nos quais as vinculações podem ser benéficas ${ }^{233}$. MARGARET WILKINSON ${ }^{234}$ adverte, no entanto, que a vinculação nestes casos não pode ser utilizada como reveladora das preferências individuais, visto a possibilidade de distorções econômicas nestes tipos de vinculação.

ROBERT MCGEE ${ }^{235}$ enxerga também outra vantagem no estabelecimento das vinculações: com a sua instituição, o desperdício de verbas para programas ou políticas

${ }^{229}$ Convém destacar também a importante sistematização acerca das razões da vinculação elaborada por ANTONio LuCiAnO DE SOUSA FRANCO (Manual..., p. 707-08), qual seja:

- Razões políticas: é mais facilitada a cobrança de impostos quando justificada para cobrir certas finalidades, servindo como uma garantia aos contribuintes;

- Razões de regularidade e prudência orçamental: para um maior desvelo orçamentário, algumas despesas ficariam restritas a fim de proteger o equilíbrio do Tesouro;

- Razões de técnica e organização do orçamento: em Portugal, por exemplo, em virtude da dinâmica orçamentária existente entre os entes autônomos, algumas dotações são realizadas com as despesas consignadas a determinados serviços do âmbito de atuação do respectivo ministério;

- Disposições legais: segundo o autor, pode servir para garantir os credores do Estado ou o controle político (função de vinculação-garantia), bem como dar racionalidade financeira ao Estado.

${ }^{230}$ Cf. AlEXANDER, Frank. Financing..., p. 383, nt. 120, com base nos diversos estudos de RonALD SNELL.

${ }^{231}$ Cf. SiLva, Mauro Santos. Vinculações..., p. 2.

${ }^{232}$ Paying..., p. 120-21.

233 Na Colômbia, a maior parte das "vinculações" para o federalismo fiscal (na modalidade de revenue sharing) é para estes dois setores. Cf. MCCLEARY, William. The earmarking..., p. 99.

${ }^{234}$ Paying..., p. 130.

${ }^{235}$ Some Tax Advice for Latvia and Other Similarly Situated Emerging Economies. International Tax \& Business Law. v. 13. 1995-96, p. 243. Neste sentido, ver também Principles..., p. 46-47, do mesmo autor. 
pork barrel ${ }^{236}$ fica prejudicado. Identifica, todavia, que receitas colocadas em um fundo comum facilitam a governança do gasto, daí porque não é em todo gasto que pode haver receita vinculada, devendo haver parcimônia no uso das vinculações. Ressurge, então, o trade-off já sublinhado ${ }^{237}$. Relata ainda outras vantagens com base nos estudos de RANJIT TEJA E BARRY BRACEWELL-MILNES ${ }^{238}$ :

“(...) avaliação próxima das preferências individuais, aumento do compliance, estabilização dos fluxos de receitas e proteção de gastos públicos mais valiosos para determinadas áreas em detrimento de projetos socialmente menos produtivos".

Também é possível extrair outros argumentos para a vinculação: ela equilibra a demanda e oferta de bens públicos (esta é a justificação trazida pela escola da escolha pública), além de facilitar a aceitação dos tributos pelo contribuinte ou, de forma alternativa, reduzir os gastos, e também promove a democracia no gasto público ${ }^{239}$.

Quanto a este último aspecto, MARGARET WILKINSON ${ }^{240}$ entende que deve haver referendos populares a fim de garantirem esta participação, para não se correr o risco de ser um mero simulacro de democracia. Porém, ressalta que, mesmo com estes referendos, o restante do gasto público continuará com as respectivas decisões concentradas no governante. Destarte, mecanismos de participação orçamentária, a nosso ver, seriam igualmente efetivos, como o que ocorre com o orçamento participativo. Concede-se, desta forma, uma visão macro-orçamentária do gasto público. Sob esta concepção, os mecanismos de vinculação seriam, portanto, apenas uma parcela da representatividade democrática no orçamento.

Isto decorre do fato que as vinculações aumentariam a transparência ${ }^{241}$ do sistema, cedendo informações aos contribuintes, que podem apoiar ou resistir à exação tributária de acordo com a função do tributo: servir a algum programa em específico ou então financiar o "desperdício" governamental. E, por consequência, pode ensejar aumento da carga

\footnotetext{
${ }^{236}$ O fenômeno do pork barrel politics ocorre quando há a absorção de recursos - principalmente nos repasses a fundos para o fomento de determinadas regiões - com escopos político-eleitoreiros. Cf. VARSANO, Ricardo; FERrEIRA, Sérgio Guimarães; AFOnso, José Roberto. Fiscal competition: a Bird's eye view. Texto para discussão n. 887. Rio de Janeiro: IPEA, 2002, p. 5.

${ }^{237}$ Ver item 1.6 supra.

${ }^{238}$ Apud MGGeE, Robert. Some tax..., p. 243, nt. 52.

${ }^{239}$ O único exemplo trazido por MARGARET WILKINSON (Paying..., p. 133-34) com relação à aceitação tributária é no tributo quid pro quo da contribuição previdenciária do empregado, visto que há uma prospecção de retorno no futuro. Outro tributo quid pro quo costumeiramente aceito é o imposto sobre gasolina, conforme será exposto no item 2.1.1 infra.

${ }^{240}$ Paying..., p. 133-34.

241 Cf. Wilkinson, Margaret. Paying..., p. 127. Segundo a doutrina econômica, ela é requisito para a vinculação de receitas, tomando como base a aplicação da teoria do benefício nos tributos - i. e., quando a identificação do pagante e do beneficiário seja evidente.
} 
tributária sem que tal atitude seja considerada impopular, caso haja profunda aceitação entre os contribuintes, implicando o aumento de receita governamental ${ }^{242}$. Por conta disto, a existência de fundos aos quais sejam vinculadas verbas confidenciais não é recomendável, como ocorre na Constituição da República do Cabo Verde, nos termos da Lei Constitucional $n^{\circ} 1 /$ V/99 de 23 de Novembro ${ }^{243}$.

Porém, SUSANNAH CAMIC ${ }^{244}$ reconhece que pode haver um efeito adverso: a partir da concepção de que os tributos vinculados possuem maior aceitação, os programas custeados pelo orçamento geral podem ficar à revelia deste processo. Não obstante isso, antes que se conclua que a autora pretende propor a vinculação de todos os tributos, ela coloca a questão de que fixar a quantidade de programas custeados por receita vinculada em comparação àqueles que não possuem tal benefício é o grande desafio dos governantes para uma boa gestão política.

Outro lado positivo - amiúde não considerado quando é efetuada uma vinculação de receitas - é a possibilidade de se garantir a equidade e a justiça financeira ${ }^{245}$ apregoada por FRANCISCO JOSÉ CARRERA RAYA ${ }^{246}$. A equidade na destinação dos recursos públicos é um princípio - previsto constitucionalmente na Espanha - afeto aos gastos públicos em sua faceta material. Visa a garantir que o juízo de valor do administrador seguirá a equidade e bondade na distribuição dos recursos públicos ${ }^{247}$. A destinação de verbas que desobedeça a estes critérios viola o sobredito princípio de justeza financeira. As vinculações viriam, então, para reforçar a aplicação deste postulado.

Por fim, o argumento utilizado pelos críticos e visto com bons olhos pelos louvadores das vinculações (reforçando a existência do trade-off) é que elas podem acarretar o estabelecimento de amarras, pelo governante atual, aos seus sucessores, que podem ter diferentes metas e objetivos de seu predecessor ${ }^{248}$. Esta é a característica principal da vinculação segundo WILLIAM MCCLEARY ${ }^{249}$, pois protegeria um gasto das

\footnotetext{
${ }^{242}$ Cf. CAMIC, Susannah. Earmarking..., p. 77-78.

${ }^{243}$ Art. 94, item 4: "Para a realização de actividades de carácter confidencial de interesse do Estado, podem, excepcionalmente, existir verbas confidenciais cuja gestão é sujeita a um regime especial de controlo e de prestação de contas nos termos da lei."

${ }_{244}$ Earmarking..., p. 78-79.

${ }^{245}$ Cf. CATÃO, Marcos André Vinhas. Novas perspectivas..., p. 570. Este caráter positivo é questionado pelo autor, pois poderia provocar o desinteresse dos Poderes Executivo e Legislativo pela promoção de um gasto público sob a égide de uma redistribuição mais justa das receitas tributárias.

${ }_{246}$ Manual de derecho financiero. v. I. Madrid: Tecnos, 1994, p. 99-100.

${ }^{247}$ Cf. CARrera RAYA, Francisco José. Manual de derecho financiero. v. I. Madrid: Tecnos, 1994, p. 100, sendo esta também a opinião de MARTín QUERALT e LOZANO SERRANO.

${ }^{248}$ Cf. Brett, Craig; KeEn; Michael. Political..., p. 336. Esta é a premissa também utilizada no trabalho de VICENT ANESI (Earmarked..., p. 681).

${ }^{249}$ The earmarking..., p. 82.
} 
vicissitudes políticas, colocando-o em piloto automático. Quanto a esta última assertiva, adicionamos que, com determinado gasto redundando em certa automaticidade, ele mesmo - uma vez iniciado - "grava" o orçamento presente e os seus subsequentes, em uma forma simbólico-institucional $^{250}$.

O que é considerado como criticável em determinadas situações demonstra-se, todavia, pertinente em outras. Depreende-se, portanto, que o trade-off das vinculações externa-se pela verificação do ponto de partida que se toma para a sua análise, fazendo-se imperioso concluir que as vinculações não são "boas" ou "ruins" em razão de sua própria natureza, mas sim pertinentes ou impertinentes de acordo com o ideal que se pretende salvaguardar.

\subsection{FALSAS AFETAÇÕES DE RECEITAS E ESTIMATIVA DA ARRECADAÇÃO}

JOSÉ JOAQUIM TEIXEIRA RIBEIRO ${ }^{251}$ diferencia as vinculações de receitas mendaciosas daquelas propriamente ditas. Explica que, com a criação de um serviço público, há o aumento correlato de despesas. Com isto, é criado um imposto novo, podendo haver uma denominação que o remeta a esta despesa específica. Mas, neste caso, não há vinculação, pois as receitas deste determinado imposto poderão ser destinadas à cobertura de outras despesas, e também porque as despesas serão realizadas à medida que o gasto seja efetivado.

Esta mera aproximação de receitas a um serviço determinado é um fenômeno exposto por JOSÉ MARTINHO SIMÕES ${ }^{252}$ já no início do século passado, ao também a rechaçar como vinculação:

Sempre que é criada uma receita nova para ocorrer a certos aumentos de despêsa, provenientes de reorganisação ou criação de serviços, essas receitas, servem geralmente para engrossar o fundo único das receitas gerais e não constituem consignação a certas despesas, enquanto não forem afectadas especialmente ao serviço que as originou. (grifo do autor)

Por exemplo, supondo que haja a necessidade de se prover o serviço público de recapeamento de ruas e seja criado o "imposto do recapeamento": neste comenos, não há,

\footnotetext{
${ }^{250}$ Ver item 1.3.2 supra.

${ }^{251}$ Lições..., p. 66-67.

${ }^{252}$ Finanças..., p. 649.
} 
forçosamente, a vinculação de receitas ao serviço público (recapeamento de ruas), pois as receitas, quando ingressarem no orçamento, poderão ser livremente distribuídas tendo em vista a aplicação dos princípios da universalidade e unidade, conforme se verá algures. Nesta conjuntura, trata-se de uma falsa vinculação, criando uma ilusão aos contribuintes de que o recurso do imposto pago será necessariamente (e somente) aplicado na razão de sua origem.

Por outro lado, se há a respectiva consignação legal ou constitucional das receitas, a aplicação dos recursos passa a ser necessariamente vinculada à despesa que a originou. Outra característica é que, em tese, a receita só poderá ser utilizada à proporção que ingresse nos cofres públicos, podendo variar de acordo com a arrecadação obtida ${ }^{253}$. Esta é a verdadeira afetação de receitas.

Diante da vinculação, pode surgir também o que JOSÉ JOAQUIM TEIXEIRA RIBEIRO $^{254}$ denomina de duplo cabimento. Caso haja uma superestimação da arrecadação, o serviço não poderia gastar mais do que foi arrecadado para este determinado fim (segundo cabimento). Além disto, em complementação, deverá haver a compatibilização das despesas dentro dos créditos orçamentários gerais (primeiro cabimento).

Desta forma, conclui o autor que as consignações podem ter um caráter favorável ou desfavorável em razão do respeito à previsão da arrecadação de receitas. Favorável se houver uma arrecadação condizente com o previsto - ou superior. Desfavorável se o produto for menor do que a expectativa ${ }^{255}$.

Porém, discordamos parcialmente deste entendimento. A afetação, per se, não seria favorável em caso de subestimação da arrecadação, mas tão somente na hipótese de haver a estimação correta das receitas ${ }^{256}$. No caso brasileiro, se houver uma arrecadação que extravase o necessário e estas receitas estiverem hirtas e vinculadas a determinada programação de despesa, a possibilidade de uma gestão eficiente destes recursos ocorrerá com a sua utilização nos termos do artigo $8^{\circ}$, parágrafo único, da LRF.

De fato, de acordo com as características imanentes a qualquer atividade de administração, quanto mais recursos estiverem disponíveis, mais sucederá o seu desperdício, além do risco de desvios e malversação destas verbas públicas. Segundo

\footnotetext{
${ }^{253}$ Cf. TEIXEIRA RIBEIRO, José Joaquim. Lições..., p. 67.

${ }^{254}$ Lições..., p. 67.

${ }^{255}$ Cf. TeIXEIRA RIBEIRO, José Joaquim. Lições..., p. 67-68.

${ }^{256}$ Cf. LAFERRIERE, Julien; WALINE, Marcel. Traité élémentaire de science et de législation financières. Paris: Librairie générale de droit et de jurisprudence, 1952, p. 95. Frise-se, todavia, que se a quantidade de receita vinculada pudesse ser totalmente prevista, não haveria diferenças entre a receita normal e a vinculada.
} 
HEINZ HALLER ${ }^{257}$, o ajuste dos gastos com base na receita é um princípio sagaz de política orçamentária, de forma que não se pode haver arrecadação menor ou, ainda, superior ao necessário. Neste último caso, deveria, na realidade, acarretar a diminuição dos tributos.

O conforto de uma situação financeira estável com sobejos e abundantes recursos pode dar azo a que a Administração Pública ${ }^{258}$ não intente os meios cabíveis e necessários a fim de se promover a eficiência e racionalização da utilização dos recursos públicos. Sábio é o ensinamento de HUGH DALTON ${ }^{259}$ nesta senda, ao dizer que “(...) um governo que disponha de mais dinheiro para gastar, poderá gastá-lo em projetos que não valham o que custam."

Diante disto, a situação favorável de se ter uma vinculação de recursos per se ocorre na exata equivalência na relação arrecadação e despesa. E caso haja uma arrecadação superior do que o esperado, deveria haver, na realidade, a redução do tributo de forma a desonerar o fardo imposto ao contribuinte.

Também, segundo relatado, não há impedimentos para uma vinculação que arrecade menos do que o previsto, caso ela seja na modalidade information-giving. Neste caso, haverá a suplementação na cobertura da despesa predeterminada por meio de fundos gerais. Só que tal vinculação, repise-se, não será plenamente eficiente por não ser bastante em si para custear o gasto.

257 Política Financiera. Trad. de MoReno, Fernando Sáinz. Madrid: Ed. de Derecho Financiero, 1963, p. 195.

${ }^{258}$ Neste ponto, utiliza-se a expressão Administração Pública e não Poder Executivo, tendo em vista o exposto por JOSÉ MAURICIO CONTI (A autonomia..., p. 33-34): “A Administração Pública é a estrutura por meio da qual o Estado (e não o Poder Executivo) organiza-se a fim de atender aos interesses públicos."

${ }^{259}$ Princípios de Finanças Públicas. 2. ed.. Trad. de ModiAnO, Maria de Lourdes. Rio de Janeiro, GB, 1970, p. 38. 


\section{AS VINCULAÇÕES APLICADAS NO ORDENAMENTO BRASILEIRO}

\subsection{VINCULAÇÕES DE RECEITAS STRICTO SENSU}

No direito brasileiro e português, LUíS SÁNCHEZ SERRANO ${ }^{260}$ ressalta a dificuldade de se encontrar lucubrações estritamente relacionadas ao direito financeiro, tendo em vista que a maioria dos estudos debruça-se sobre aspectos fiscais ou tributários de um determinado instituto. Diante disto, as investidas históricas às origens de um instituto de direito financeiro soem apresentar diversas disparidades entre si. Nesse sentido, poder-se-á observar a dificuldade de se identificar a origem das vinculações no Brasil.

ARIOSTO DE REZENDE ROCHA ${ }^{261}$ menciona que, no período imperial, a doutrina já costumava dividir as receitas em gerais ou especiais. A geral, como o próprio nome diz, custearia os fins comuns e gerais estatais; já as especiais serviriam excepcionalmente para um ramo da despesa pública, como, $v$. g., a Lei $\mathrm{n}^{\circ} 2.040$, de 28 de setembro de 1871, que auxiliava a emancipação dos escravos mediante a criação de um fundo específico para este fim. Há, entretanto, o alerta de que já na Constituição de 1824 começou-se a introduzir exceções à regra da livre destinação de receitas, admitindo-se a especialização de rendas especiais desde que destinadas ao pagamento dos juros e amortização da dívida pública ${ }^{262}$.

O legislador brasileiro passou então, como fazem nas outras nações, a vincular as receitas a determinados setores ou atividades reputados imprescindíveis para o

\footnotetext{
${ }^{260}$ Tratado..., p. 73.

${ }^{261}$ Rendas gravadas. Manaus: Faculdade de Direito do Amazonas, 1954, p. 53.

${ }^{262} \mathrm{O}$ dispositivo em comento é o artigo 171 da Constituição Política do Império do Brasil de 1824: “Art. 171. Todas as contribuições directas, á excepção daquellas, que estiverem applicadas aos juros, e amortisação da Divida Publica, serão annualmente estabelecidas pela Assembléa Geral, mas continuarão, até que se publique a sua derogação, ou sejam substituidas por outras." Cf. este histórico constitucional em RocHA, Ariosto de Rezende. Rendas..., p. 55, com base nos estudos de AMARO CAVALCANTI.
} 
desenvolvimento da nação e garantia de direitos aos indivíduos, e também a fim de manter a saúde financeira dos entes federativos.

Estes desideratos, obviamente, não são exclusivos do ordenamento brasileiro, mas também são verificáveis em outros países sul-americanos. Como exemplo, o artigo 298, item 2, da Constituição da República do Uruguai estabelece que a lei que define o orçamento dos entes departamentais poderá destinar ao desenvolvimento do interior do país uma parcela (alíquota) dos tributos arrecadados fora do departamento de Montevidéu, que formará um fundo vinculado ao financiamento destes programas de investimento ${ }^{263}$. $\mathrm{Na}$ Argentina, foi criado um imposto sobre o lucro (Impuesto a las Ganancias) com destinação de $20 \%$ do arrecadado para a seguridade social, porém, sem a formação de um fundo específico, mas sim pela afetação de recursos a determinadas finalidades ${ }^{264}$.

Volvendo ao caso brasileiro, é possível identificar que as vinculações apareceram com escopo específico - por meio de fundos, instrumento geralmente usado para operacionalizá-las. Diante disso, as vinculações stricto sensu podem ser definidas como a exata correlação entre despesa e receita, de acordo com a definição de vinculação já exarada, ou seja, são aquelas vinculações propriamente ditas, externadas de forma estrita mediante o estabelecimento de um elo entre uma fonte de receita para um escopo específico.

Com relação às vinculações stricto sensu definidas constitucionalmente, pode-se sistematizá-la da seguinte forma, na mesma esteira da esquematização de FERNANDO FACURY SCAFF ${ }^{265}$ - com algumas adaptações:

\footnotetext{
${ }^{263}$ Segundo o item, a lei poderá "Destinar al desarrollo del interior del país y a la ejecución de las políticas de descentralización, una alícuota de los tributos nacionales recaudados fuera del departamento de Montevideo. Con su producido se formará un fondo presupuestal, afectado al financiamiento de los programas y planes a que refiere el inciso quinto del artículo 230. Dicha alícuota deberá ser propuesta preceptivamente en el Presupuesto Nacional."

${ }^{264}$ Cf. CORTI, Horacio Guillermo. Derecho constitucional..., p. 317.

${ }^{265}$ Direitos humanos e a desvinculação das receitas da União - DRU. Revista de Direito Administrativo. Rio de Janeiro. n. 236. abr./jun. 2004, p. 35-36.
} 


\begin{tabular}{|c|c|c|c|c|c|}
\hline & IPI e IR & Salário-Educação & PIS-PASEP & $\begin{array}{l}\text { Contribuição } \\
\text { Social ao INSS, } \\
\text { e sobre receita } \\
\text { de concursos de } \\
\text { prognósticos, } \\
\text { COFINS, } \\
\text { COFINS - } \\
\text { Importação e } \\
\text { CSLL (art. 149 } \\
\text { e 195, CF) }\end{array}$ & $\begin{array}{l}\text { CIDE- } \\
\text { Combustíveis }^{266}\end{array}$ \\
\hline Finalidade & \begin{tabular}{l}
\multicolumn{2}{l}{ Financiamento } \\
ao setor \\
produtivo das \\
regiões N, NE e \\
$\mathrm{CO}$
\end{tabular} & $\begin{array}{l}\text { Manutenção e } \\
\text { desenvolvimento } \\
\text { do ensino }\end{array}$ & $\begin{array}{l}\text { Desenvolvimento } \\
\text { econômico e } \\
\text { programas sociais }\end{array}$ & $\begin{array}{l}\text { Financiamento } \\
\text { dos programas } \\
\text { referentes à } \\
\text { Seguridade } \\
\text { Social }\end{array}$ & $\begin{array}{l}\text { Pagamento de } \\
\text { subsídios a preços ou } \\
\text { transporte de álcool } \\
\text { combustível, gás } \\
\text { natural e seus } \\
\text { derivados e } \\
\text { derivados de } \\
\text { petróleo; } \\
\text { financiamento de } \\
\text { projetos ambientais } \\
\text { relacionados com a } \\
\text { indústria do petróleo } \\
\text { e do gás; } \\
\text { financiamento de } \\
\text { programas de } \\
\text { infraestrutura de } \\
\text { transportes }\end{array}$ \\
\hline Vinculação & $3 \%$ & $\begin{array}{l}\text { a) } 90 \% \text { do seu } \\
\text { valor: } \\
\text { 1/3 ao Fundo } \\
\text { Nacional de } \\
\text { Desenvolvimento } \\
\text { da Educação; } \\
\text { 2/3 às Secretarias } \\
\text { de Educação; } \\
\text { b) 10\% a } \\
\begin{array}{l}\text { programas de } \\
\text { universalização da } \\
\text { saúde básica. }\end{array}\end{array}$ & $\begin{array}{l}40 \% \text { ao BNDES } \\
60 \% \text { ao FAT, para } \\
\text { determinados } \\
\text { programas sociais }\end{array}$ & $100 \%$ & $71 \%$ \\
\hline Total & $3 \%$ & $100 \%$ & $100 \%$ & $100 \%$ & $71 \%$ \\
\hline
\end{tabular}

Tabela 1: Principais vinculações constitucionais a programas específicos de desenvolvimento.

Além destas formas expressamente previstas, há também outras permissões constitucionais de vinculações sem determinação de montantes percentuais fixos.

${ }^{266}$ Cf. CHARBESKI, Heron. Desvio orçamentário de finalidade das contribuições à luz do federalismo fiscal brasileiro: o caso Cide-combustíveis. Revista Dialética de Direito Tributário. São Paulo. n. 128. mai. 2006, p. 21-24. O autor explica o movimento da federação brasileira com a Emenda Constitucional no 42/2003, que introduziu a figura da contribuição interventiva no setor petrolífero e derivados. Desta forma, cambiou-se o modelo de repartição de receitas, pautado exclusivamente em impostos, com a inclusão da CIDE nas repartições para o federalismo fiscal. Porém, estas transferências ficaram vinculadas às razões de origem da instituição do tributo, conforme expostas na tabela. Inclusive, segundo o autor, a tredestinação da aplicação destes recursos invalidaria a própria transferência intergovernamental, citando como base o art. $1^{\circ}$ - A, $\S 7^{\circ}$, da Lei $n^{\circ} 10.366 / 01$. 
FRANCISCO AlVES dOS SANTOS JÚNIOR ${ }^{267}$ cita, por exemplo, (i) a destinação de recursos para a realização de atividades da administração tributária ${ }^{268}$; (ii) destinação da prestação de garantia às operações de crédito por antecipação de receita orçamentária (AROs) (ambas previstas no art. 167, IV, CF); (iii) destinação de recursos para a reforma agrária (artigo 184, § 4 $4^{\circ}, \mathrm{CF}$ ); (iv) destinação de recursos para irrigação (artigo 42 do Ato das Disposições Constitucionais Transitórias - ADCT).

Porém, não podemos concordar com o entendimento de que o artigo $184, \S 4^{\circ}$, da Constituição consigna uma afetação de receitas. $\mathrm{O}$ indigitado dispositivo proscreve:

Art. 184. Compete à União desapropriar por interesse social, para fins de reforma agrária, o imóvel rural que não esteja cumprindo sua função social, mediante prévia e justa indenização em títulos da dívida agrária, com cláusula de preservação do valor real, resgatáveis no prazo de até vinte anos, a partir do segundo ano de sua emissão, e cuja utilização será definida em lei.

§ $4^{\circ}$ - O orçamento fixará anualmente o volume total de títulos da dívida agrária, assim como o montante de recursos para atender ao programa de reforma agrária no exercício.

Neste caso, não se trata de uma vinculação de receitas, mas sim de uma mera observância à qual a peça orçamentária deve relevar quando da sua feitura. O Orçamento da União irá fixar o total de títulos da dívida agrária, em razão das desapropriações, para os fins indenizatórios a que se presta. Caso se entendesse tal prática como vinculação, o regime de precatórios também seria uma espécie de afetação, tendo em consideração que há a automática limitação da liberdade orçamentária do ente federativo com o advento do trânsito em julgado da decisão judicial. Nestes casos, não há a formação do elo entre fonte e destino, mas tão somente o dever de gastar pelo Estado ${ }^{269}$.

Quanto ao montante de recursos para atender ao programa da reforma agrária, deve-se conceber esta expressão como uma disposição geral, sem nenhuma vinculação específica. É como se o texto constitucional dispusesse que o orçamento deve fixar verbas para programas de inclusão digital. Não há lindes e nem receitas especificadas, de forma

\footnotetext{
${ }^{267}$ Curso de direito financeiro. Campinas: Bookseller, 2006, p. 52.

268 Além desta permissão, há a existência do FUNDAF - Fundo Especial de Desenvolvimento e Aperfeiçoamento das Atividades de Fiscalização, instituído pelo artigo $6^{\circ}$ do Decreto-lei $\mathrm{n}^{\circ}$ 1.437/1975, cujos recursos são “(...) destinado a fornecer recursos para financiar o reaparelhamento e reequipamento da Secretaria da Receita Federal, a atender aos demais encargos específicos inerentes ao desenvolvimento e aperfeiçoamento das atividades de fiscalização dos tributos federais e, especialmente, a intensificar a repressão às infrações relativas a mercadorias estrangeiras e a outras modalidades de fraude fiscal ou cambial, inclusive mediante a instituição de sistemas especiais de controle do valor externo de mercadorias e de exames laboratoriais." O fundo é constituído pelas receitas oriundas dos selos de controle expedidos pela Receita Federal do Brasil. O referido diploma foi regulamentado pela Instrução Normativa da Secretaria da Receita Federal no 180/2002.

${ }^{269}$ Ver item 2.2.2 infra.
} 
que se prejudica a inclusão deste caso no rol das vinculações de receitas em sentido estrito previstas na Constituição da República ${ }^{270}$.

A Carta ainda faculta aos demais entes federativos a promoção de diversas vinculações. O artigo 204, parágrafo único, permite que Estados e Distrito Federal vinculem até $0,5 \%$ de sua receita tributária líquida a programas de apoio à inclusão e promoção social, ressalvadas algumas hipóteses proibitivas na utilização destes recursos. $\mathrm{O}$ artigo 216, $\S 6^{\circ}$, também faculta a estes entes mencionados o mesmo percentual de vinculação a fundo estadual/distrital a fim de fomentar a cultura, financiando programas e projetos culturais, também com algumas ressalvas proibitivas ${ }^{271}$.

Igualmente é importante mencionar o permissivo contido no artigo $218, \S 5^{\circ}$ da Constituição Federal, que faculta aos Estados e Distrito Federal, mediante a respectiva Constituição Estadual ou Lei Orgânica do Distrito Federal, vincular parcela da receita orçamentária às instituições de ensino e pesquisa científica. Neste ponto, não é estabelecido um percentual, ficando a critério de cada Assembleia estadual a sua fixação. Ressalve-se que não estão incluídas as receitas de impostos, já que o artigo 167, IV, por ser regra específica, define o âmbito de interpretação do dispositivo.

Não é despiciendo ressaltar a hipótese de vinculações infraconstitucionais: os instrumentos corriqueiramente utilizados para tanto são os já mencionados fundos orçamentários. Evidentemente, o ordenamento constitucional deverá permitir tal flexibilidade, como começou a tomar forma com a Constituição de $1946^{272}$. Neste caso, conclui ARIOSTO DE REZENDE ROCHA ${ }^{273}$ que a vinculação sob as regras constitucionais é totalmente plausível, não ferindo o princípio da universalidade, desde que figure no orçamento de forma abrangente - como receita geral - e, somente então, seja dotada à satisfação de determinado fim, i. e., a despesa devidamente especificada.

Com a Constituição de 1988, houve a nítida proibição da vinculação infraconstitucional de impostos ${ }^{274}$; os demais tributos ou recursos públicos, todavia, são plenamente vinculáveis por meio de leis ordinárias. Como exemplo, pode-se citar o artigo

\footnotetext{
${ }^{270}$ Ver item 1.2 supra.

${ }^{271}$ Ver item 4.1.2.2 infra.

${ }^{272}$ Cf. RochA, Ariosto de Rezende. Rendas..., p. 72. Cf. também Silva, José Afonso da. Tributos e normas de política fiscal na Constituição do Brasil. São Paulo: s.n., 1968, p. 100, nt. 151. Este último ressalta que, na prática, a Constituição de 1946 vinculou tantas receitas que praticamente desconsiderou a regra da não afetação de receitas. Segundo MARTA ARRETCHE (Quem taxa e quem gasta: a barganha federativa na federação brasileira. Revista de Sociologia e Política. São Paulo. n.24. jun. 2005, p. 81), houve a inauguração do sistema de vinculações nesta Carta.

${ }^{273}$ Rendas..., p. 80.

${ }^{274}$ Ver item 3.3.2 infra.
} 
320 da Lei no 9.503/1997 - Código de Trânsito Brasileiro. É permitida a vinculação dos recursos advindos das multas de trânsito para as suas atividades típicas, prevendo-se, inclusive, a criação de fundo para fomentar a segurança e educação no trânsito. Estes recursos estão livres, portanto, para serem afetados a qualquer atividade ou ente específicos.

\subsubsection{TRIBUTAÇÃO SOBRE COMBUSTÍVEIS E VINCULAÇÃO}

\subsubsection{ESCORÇO HISTÓRICO E COMPARATIVO}

É prática recorrente a vinculação de receitas a tributação sobre combustíveis a fim de fomentar as políticas de transporte nacionais ${ }^{275}$. JACOB WILNER SUNDELSON ${ }^{276}$ destacou em seus estudos que as infrações à proibição de afetação das receitas costumam estar relacionadas às receitas que proporcionam o benefício em uma ligação explícita com o contribuinte.

Isto ocorre porque esta é uma modalidade de vinculação quid pro quo, visto que o item tributado aparece como complementar ao serviço que deve ser prestado pelo ente governamental. Desta forma, considera-se que aqueles que pagam pouco pelo tributo o fazem porque não consomem frequentemente o serviço prestado, e, reciprocamente, o alto consumo implica maior carga tributária sobre este contribuinte ${ }^{277}$. É realizada uma grande aproximação com o princípio do benefício.

Diferentemente ocorre com o financiamento geral por meio de um fundo ou uma vinculação unilateral, já que nesses casos não há correlação entre a tributação e o serviço gozado pelo contribuinte. Um exemplo claro é a vinculação de um tributo sobre loterias para saúde ou educação. Tal modalidade é destacada pela doutrina como maximizadora do fenômeno do rent-seeking, diferentemente das vinculações quid pro quo, que limitariam a dissipação de gastos em períodos eleitoreiros ${ }^{278}$.

\footnotetext{
${ }^{275}$ Não é por acaso que este costume de vincular receitas oriundas da tributação dos combustíveis continua se verificando. Na Argentina, recentemente a Ley $n^{\circ} 24.464$ criou um Fundo Nacional de Habitação com recursos vinculados oriundos do imposto sobre os combustíveis. Cf. CoRTI, Horacio Guillermo. Derecho constitucional..., p. 315. Porém, trata-se de uma vinculação fraca, sem a correlação entre pagamento e benefício - própria dos tributos sobre combustíveis.

${ }^{276}$ Budgetary..., p. 262.

277 Cf. WYricK, Thomas L.; ARnOLD, Roger A. Earmarking as a deterrent to rent-seeking. Public Choice. v. 60. p. 283-91. mar. 1989, p. 284.

${ }^{278}$ Cf. WYRICK, Thomas L.; ARNOLD, Roger A. Earmarking..., p. 284, 289-90.
} 
Nos Estados Unidos, dada a vigência do princípio das user-fees, os próprios usuários, em regra, financiam os serviços públicos utilizados, por meio de tributos afetados à construção e manutenção rodoviária ${ }^{279}$. Neste caso, aqueles pagos sobre o combustível, veículos ou pneus servem para formar um fundo orçamentário com o fim de construir e administrar as rodovias deste país ${ }^{280}$. Para se ter dimensão da amplitude do uso desta vinculação, $85 \%$ dos 46 estados utilizavam a vinculação sobre combustível automotor para financiar a construção de rodovias em $1979^{281}$.

Quanto ao imposto pago sobre o combustível (fuel taxes), embora estas receitas atualmente não atinjam nem $2 \%$ da arrecadação total, cumpre salientar que possuem um papel político relevante no cenário estadunidense. Surgida no âmbito federal em 1932, incidia um centavo sobre o valor dos galões de gasolina. Era temporária (somente por um ano) e serviria para cobrir o déficit estatal do momento. Com o tempo, foi estabelecido o Fundo Rodoviário em 1956 pelo Federal Aid Highway Act ${ }^{282}$.

Os louvadores dos fuel taxes costumam observar que, tendo em vista que o consumo de combustível dificilmente se altera ano após ano, a vinculação desta receita para a manutenção de vias rodoviárias costuma ser vantajosa por permitir, estimadamente, a previsão da receita a ser auferida e investida no setor. Ademais, há que se considerar o aspecto popular de tal tributo, considerando que os contribuintes conseguem enxergar, de forma límpida, a correlação entre exação e investimento ${ }^{283}$. Advoga-se, também, pela existência de seu caráter extrafiscal, pois fomentaria o desenvolvimento de novas tecnologias menos poluidoras ${ }^{284}$, o que, a nosso ver, é irrelevante no tocante à vinculação, ou não, de sua receita ${ }^{285}$.

No entanto, critica-se a falta de progressividade do tributo, porquanto incidiria mais pesadamente sobre os menos afortunados. Igualmente, prejudicaria as populações rurais e indivíduos que devem usar o veículo para trabalhar, que tenderiam a se utilizar

\footnotetext{
${ }^{279}$ Cf. VALDÉs, José Andrés Rozas. Una aproximación a la financiación de autopistas, desde la experiencia española. In: TôRRES, Heleno Taveira. Serviços públicos e direito tributário. São Paulo: Quartier Latin, 2005, p. 565.

${ }^{280}$ Cf. GARCÍA, Gloria Alarcón. Financiación privada de obras públicas. In: FUNDACIÓN PARA LA PROMOCIÓN DE LOS ESTUDIOS FINANCIEROS. Las nuevas fórmulas de financiación de infraestructuras públicas: LI Semana de Estudios de Derecho Financiero. Madrid: Ministerio de Economía y Hacienda - Instituto de Estudios Fiscales, 2008, p. 102.

${ }^{281}$ Cf. WYrICK, Thomas L.; ARnOLD, Roger A. Earmarking..., p. 284.

${ }^{282}$ Cf. Simonson, Kenneth D. Fuel taxes, federal. In: CORDES, Joseph J.; Ebel, Robert D.; Gravelle, Jane G. (editors). The encyclopedia of taxation \& tax policy. 2. ed. Washington, D.C: Urban Institute Press, 2005, p. $162-63$.

${ }^{283}$ Cf. Clague, Ewan; GoRdon, Joel. Earmarking..., p. 11.

${ }^{284}$ Cf. SimOnSON, Kenneth D. Fuel..., p. 163.

${ }^{285}$ Ver item 1.5.2 supra.
} 
mais dos combustíveis petrolíferos do que os demais, criando desigualdades horizontais ${ }^{286}$. Outro problema é que, para se ter um acréscimo nos investimentos, faz-se mister o aumento do imposto vinculado que custeia o fundo rodoviário ${ }^{287}$. Há, ainda, a questão de que variações como peso ou tamanho do veículo negariam o princípio do benefício na aplicação desta vinculação ${ }^{288}$. Questiona-se também que, em cidades mais congestionadas, os custos indiretos arcados pelos motoristas em virtude desta tributação seriam maiores do que os suportados pelos utentes de $\operatorname{rodovias}^{289}$. E, por fim, não é sinônimo de garantia de aplicação da receita, dado que o governo estadunidense passou a desviar o produto da arrecadação destes tributos - o que ensejou diversos protestos dos contribuintes com base na legislação que fixava de forma expressa a vinculação para a construção rodoviária, vedando a tredestinação da receita para outras áreas ${ }^{290}$.

A despeito desta quizila doutrinária nos Estados Unidos, o fato é que a vinculação da receita destes tributos para o financiamento deste tipo de infraestrutura não demonstra uma eficácia palpável. Prova disto é que o furor inicialmente experimentado pelo Banco Mundial pelas vinculações neste setor diminuiu nos últimos tempos, principalmente depois de algumas experiências frustradas no final do século passado. Diante disto, para o seu sucesso, o órgão sugeriu alguns pontos necessários à sua plena efetivação: (i) a existência de agência a fim de controlar estes recursos e os programas respectivos; (ii) a impossibilidade de uso dos recursos destes fundos rodoviários para outras finalidades; (iii) a existência de transparência e controle; e (iv) a instituição de programas de finita duração ${ }^{291}$.

WILliAm MCCLEARY ${ }^{292}$ aponta que países como a República Centro-Africana, Colômbia, Mali e Zaire obtiveram resultados insatisfatórios na vinculação de recursos para o desenvolvimento rodoviário, principalmente porque estes fundos eram utilizados como manobras na burocracia orçamentária. Somente Gana teve algum sucesso, pois possuía programa que incentivava altos gastos no setor.

\footnotetext{
${ }^{286}$ Cf. SimOnSOn, Kenneth D. Fuel..., p. 163.

${ }^{287}$ PATRICK JONES, presidente do IBTTA, explica que o aumento dos impostos relacionados aos combustíveis (modelo de financiamento mais utilizado) e a concessão à iniciativa privada são as únicas formas de se incrementar os investimentos na infraestrutura rodoviária dos Estados Unidos. Porém, como os aumentos destes impostos pelos congressistas costumam sofrer grande resistência popular, o modelo de concessões seria interessante para se driblar estas restrições. Cf. em MACHADO, Ana Paula. Entrevista com Patrick Jones: "EUA têm muito a aprender sobre concessão no Brasil". Brasil Econômico. 20 nov. 2009, p. 24-25)

${ }^{288}$ Cf. ClaGUe, Ewan; Gordon, Joel. Earmarking..., p. 10.

${ }^{289}$ Cf. WILKInSON, Margaret. Paying..., p. 131.

${ }^{290}$ Cf. Clague, Ewan; Gordon, Joel. Earmarking..., p. 11.

${ }^{291}$ Cf. MCCLEARY, William. The earmarking..., p. 91.

${ }^{292}$ The earmarking..., p. 91-92.
} 
Hodiernamente, a falta de independência financeira pública costuma ser alvo de questionamentos: a maioria das rodovias mantidas por um Estado não possui um fundo de despesas para este fim, ficando à mercê dos investimentos governamentais específicos ${ }^{293}$. Diversamente, países mais desenvolvidos possuem importantes fundos de financiamento de infraestrutura. Destarte, inclinamo-nos pelo fomento à utilização destes fundos voltados à infraestrutura como meio também eficaz e alternativo de incentivo, dadas as dificuldades encontradas na operacionalização das vinculações de tributos sobre combustíveis.

Porém, mais uma vez o trade-off das vinculações reaparece, pois ficou demonstrado que estes fundos tiveram seus recursos desviados nos exemplos dos países africanos citados, de forma que dependerá das premissas adotadas em um determinado país para a conveniência de sua aplicação.

\subsubsection{A VINCULAÇÃO SOBRE COMBUSTÍVEIS NO BRASIL}

No Brasil, é possível chancelar as observações estadunidenses e dos demais países pela análise do contexto da infraestrutura rodoviária nacional. Estudos mostram que o País ocupa a sexta posição mundial no tocante à sua frota de veículos automotores (aproximadamente 32 milhões). A extensão total de rodovias coloca-o em quarto lugar no mundo (com aproximadamente 1,6 milhão de quilômetros). Contudo, quando esmiuçada a questão da extensão de rodovias pavimentadas, despenca para a décima terceira colocação, por volta de 196 mil quilômetros de pavimentação. Já na relação extensão da malha rodoviária/extensão da pavimentação, o Brasil cai para a vigésima posição, com pouco mais de $12,2 \%$ de estradas pavimentadas ${ }^{294}$.

A ideia de vincular recursos da tributação sobre combustíveis é antiga no ordenamento pátrio. A Lei Joppert (Decreto-lei $\mathrm{n}^{\circ}$ 8.463, de 27 de dezembro de 1945) instituiu o Fundo Rodoviário Nacional - FRN, deflagrando a "era de ouro" dos investimentos públicos em infraestrutura. A fase mais próspera de investimentos em infraestrutura deu-se entre 1977 a 1982, tendo em vista o imenso aporte de capital estrangeiro para investimentos ocorrido nesta época ${ }^{295}$. Os recursos do Imposto Único

\footnotetext{
${ }^{293}$ Cf. Roth, Gabriel. Roads in a Market Economy. Aldershot: Ashgate, 1996, p. 28.

294 Cf. ViannA, Geraldo Aguiar de Brito. O mito do rodoviarismo brasileiro. 2. ed. São Paulo: NTC\&Logística, 2007, p. 27-33.

295 Cf. PÊGo FILHo, Bolívar; CÂNDIDO JÚNIOR, José Oswaldo; PEREIRA, Francisco. Investimento e financiamento da infra-estrutura no Brasil: 1990/2002. Brasília: [s.n.], 1999, p. 13. Disponível em: <http://www.ipea.gov.br/pub/td/td_99/td_680.pdf> . Acesso em: 31 ago. 2008.
} 
Federal sobre Combustíveis e Lubrificantes Líquidos Minerais custearam as obras rodoviárias nacionais, cuja repartição de receitas deu-se na seguinte fração: $60 \%$ aos Estados e $40 \%$ à União Federal. Em um momento posterior, esta fração de $60 \%$ foi reduzida em $48 \%$, e o restante distribuído aos Municípios.

Porém, diante de vicissitudes político-econômicas, e com o advento da proibição clara pela então recente Constituição Federal de 1988 em vincular recursos que extravase a permissão a contrario sensu do artigo 167, IV (incluindo também a proibição da vinculação de impostos sobre combustíveis), intentou-se, a partir do início da década de noventa, uma mudança do paradigma estatal do Estado-investidor, dada a escassez de recursos destinados ao setor.

Com isto, o pedágio, fonte alternativa de financiamento, obteve elevado desenvolvimento a partir de 1993 sob a regência do Programa Nacional de Concessões Rodoviárias $^{296}$. Então, de 1994 em diante, as concessões no setor de infraestrutura ganharam fôlego em detrimento do uso das verbas públicas para o custeio desta atividade; mormente sob a batuta do Conselho Nacional de Desestatização - CND, deu-se vazão ao Programa Nacional de Desestatização - PND, transferindo-se estas atividades à iniciativa privada. O CND é o órgão executor do Programa Nacional de Desestatização, subordinado hierarquicamente ao Presidente da República. Originalmente, foi concebido para ser composto pelos seguintes membros: Ministro do Planejamento e Orçamento (Presidente do CND); Ministro da Casa Civil; Ministro da Fazenda; Ministro da Administração Federal e Reforma do Estado; Ministro da Indústria, do Comércio e do Turismo. Ainda, sem direito a voto, pode haver a participação de um representante do BNDES, banco gestor do PND. Compete ao CND deliberar sobre a inclusão ou exclusão de algum serviço público no PND, e também a aprovação de qual modalidade operacional dar-se-á a cada desestatização decidida ${ }^{297}$.

A CIDE-Combustíveis brasileira é outro exemplo cristalino que despontou após este contexto: a despeito da existência de vinculação da arrecadação ao financiamento de programas de infraestrutura de transportes, o que se vê é uma expansão das concessões

\footnotetext{
${ }^{296}$ Cf. SennA, Luiz Afonso dos Santos, e Michel, Fernando Dutra. Rodovias auto-sustentadas: o desafio do século XXI. São Paulo: Editora CLA, 2006, p. 435-36.

${ }^{297}$ Cf. Stuber, Walter Douglas. O financiamento de projetos no Brasil e a lei de concessões. São Paulo: Max Limonad, 1996, p. 35-38. O autor aponta as origens do Programa Nacional de Desestatização, instituído pela Lei $\mathrm{n}^{\mathrm{o}} 8.031 / 90$, alterado pela MP $\mathrm{n}^{\mathrm{o}} 1.481-42 / 96$, e criado com o escopo de reduzir, de forma progressiva, a atuação do Estado na economia.
} 
rodoviárias, portuárias e ferroviárias à iniciativa privada, tendo em vista a impossibilidade de suprimento da demanda somente pelas verbas deste tributo ${ }^{298}$.

Em suma, apercebe-se que a vinculação das receitas oriundas da tributação sobre combustíveis é prática recorrente, tendo tal concepção prosperado em alguns países - a exemplo dos Estados Unidos - ou sido abandonada em outros, tal como no Brasil, apesar de, neste país, ainda haver um resquício ${ }^{299}$ de se tentar conceber a tributação vinculada à expansão rodoviária, como ocorre com a CIDE-Combustíveis.

Noutro sentido, SANDER MAGALHÃES LACERDA ${ }^{300}$ enxerga vantagens à vinculação de tributos para a infraestrutura rodoviária, à proporção que o tributo incida primordialmente sobre os maiores consumidores do serviço. Diante disto, expõe - apesar das críticas quanto ao engessamento orçamentários das vinculações - que:

Por outro lado, o financiamento das rodovias através de recursos vinculados oferece vantagens em relação à alternativa de utilização de receitas tributárias sem vinculação, ou seja, dos impostos em geral. Quando os recursos para as rodovias têm origem nas receitas tributárias sem vinculação, a relação entre o quanto cada usuário das rodovias contribui para sua manutenção, através do pagamento de tributos, e o quanto ele impõe de desgaste às rodovias torna-se imprecisa.

Atualmente, o modelo tarifário de cobrança de pedágio veio a diminuir a importância da vinculação sobre combustíveis, uma vez que o preço público permite a precisa correlação e individualização do serviço prestado e a contraprestação pecuniária pela sua respectiva utilização. Neste contexto, o usuário beneficiário do serviço é

\footnotetext{
298 Ademais, não é despiciendo mencionar a ressalva de MAURICIO PORTUGAL RIBEIRo e LUCAS NAVARRO PRADO (Comentários à Lei de PPP - Parceria Público-Privada: fundamentos econômico-jurídicos. São Paulo: Malheiros, 2007, p. 221 e 224) de que boa parte destes recursos estaria entesourada para cumprimento das metas de superátiv primário do Governo Federal, igualmente o que vem ocorrendo com o FUST. Ver também item 4.1.3.3 infra.

${ }_{299}$ O Projeto de Lei n ${ }^{\circ}$ 463/2006 da Assembleia do Estado de São Paulo, de autoria do Deputado Antonio Mentor do Partido dos Trabalhadores - PT, autoriza, em seu artigo $1^{\circ}$, o Poder Executivo a conceder um abatimento no IPVA com base nos valores recolhidos a título de pedágio nas rodovias estaduais, exploradas diretamente ou por meio de concessão. Tal benefício seria limitado a $30 \%$ para pessoas físicas, e a $10 \%$ às pessoas jurídicas. Não obstante os elevados desígnios legislativos, há que se considerar a eiva pelo vício de iniciativa, em homenagem ao artigo 165 da Constituição Federal, que chancela ao Executivo a prerrogativa de legislar sobre matéria financeira, sobretudo no que diz respeito às renúncias de receitas, como é o caso. Abstraindo-se estes problemas, ressaltados, inclusive, na Mensagem de Veto $\mathrm{n}^{\mathbf{0}}$ 97/08, de 12 de junho de 2008, do Governador do Estado, (publicada no Diário da Assembleia do Estado de São Paulo. 13 jun. 2008 , p. 9 e 10), pode-se dizer que se trataria de uma renúncia de receitas equivocada em sua premissa, visto que erroneamente considera o IPVA como um imposto vinculado à atividade rodoviária. Ao prever que haja a renúncia da parte da arrecadação do IPVA para a existência de uma cobrança mais justa deste imposto, tendo em vista que ele supostamente teria a mesma utilidade que o pedágio - ou seja, custear o transporte rodoviário -, abalam-se as bases jurídicas construídas na cobrança dos tributos e preços públicos. O IPVA, repise-se, custeia as despesas gerais do Estado, diferentemente do pedágio, que serve para remunerar e conservar a atividade de exploração rodoviária.

${ }^{300} \mathrm{O}$ financiamento da infra-estrutura rodoviária através de contribuintes e usuários. BNDES Setorial. Rio de Janeiro. n. 21. mar. 2005, p. 150.
} 
cristalinamente individualizado, o que permite o dispêndio exato de recursos para o serviço público em questão.

\subsubsection{VINCULAÇÕES INDIRETAS DE RECEITAS}

Com relação às vinculações constitucionais expostas, se houver dispositivo constitucional inibitório das vinculações no ordenamento, este deve ser interpretado de forma a vedar, também, as vinculações indiretas da receita de impostos.

Pode-se verificar esta modalidade em casos de concessões de benefícios à população - pela Administração Pública - com a respectiva compensação, ao prestador de um determinado serviço, mediante o aumento de alíquota ou renúncia parcial da receita de certo tributo, vinculando este acréscimo ou redução obliquamente ao custeio do benefício em questão.

A jurisprudência utiliza também a expressão redirecionar receitas com esta significação (benefícios fiscais); porém, entendemos que tal termo melhor se coaduna com o cambiamento das receitas de um ente ou órgão para outro da própria Administração, conforme já verificado ${ }^{301}$.

Na realidade, há uma vinculação de parcela, de forma indireta, da arrecadação do imposto. A vedação da vinculação indireta de impostos também decorre, sobretudo, da concepção de que é irrelevante se a receita ingressa ou não aos cofres públicos para fins de verificação do princípio da não vinculação. Desta forma, em virtude da destinação indireta destas receitas a determinado fim - porém, não pelo poder público diretamente, mas por intermédio dos contribuintes - a vinculação passa a atingir indiretamente o imposto. $\mathrm{O}$ contribuinte, ao invés de recolher determinada quantia de imposto aos cofres públicos, recolhe uma parcela menor com a respectiva promessa de investimento, em atendimento a uma política pública traçada.

À guisa de explanação, pode-se citar o surgimento de uma lei potiguar, com fins assistenciais, incumbindo ao Erário o custeio do serviço público de fornecimento de energia elétrica à população de baixa renda: para tanto, o Estado, de forma indireta, assumia o custo do benefício, já que ele era satisfeito por meio de desconto sobre o ICMS (renúncia de receitas) devido pelas concessionárias que prestavam este serviço público, que deveriam aplicar essa parcela no programa social concebido. Nesta ocasião, o Supremo

\footnotetext{
${ }^{301}$ Ver item 1.4.4 supra.
} 
Tribunal Federal ${ }^{302}$, em sede cautelar, suspendeu a eficácia da referida lei com o fundamento de que se constituía, em verdade, em uma burla indireta ao artigo 167, IV, da Constituição Federal. No final das contas, o serviço público seria custeado pela receita oriunda do ICMS, originando-se, dessarte, uma vinculação indireta do produto de sua arrecadação.

Outra forma de se utilizar este mecanismo indireto ocorreu na Ação Direta de Inconstitucionalidade $\mathrm{n}^{\mathrm{o}} 3.576-2 / \mathrm{RS}^{303}$, mediante a utilização, pelos contribuintes, de um crédito fiscal presumido de ICMS como benefício fiscal por direcionarem o valor do tributo a um fundo (Fundo Partilhado de Combate às Desigualdades Sociais e Regionais do Estado do Rio Grande do Sul). A Corte decidiu, seguindo sua linha jurisprudencial, pela procedência da ação, declarando inconstitucional a referida lei estadual.

$\mathrm{O}$ mesmo ocorreu com a ADI $\mathrm{n}^{\circ} 2.529-5 / \mathrm{PR}^{304}$ que previa um incentivo fiscal mecenato para atividades de incentivo à cultura - vinculando parte da arrecadação do ICMS para fins culturais que, apesar de louvável, caía na tentativa de vinculação indireta de receitas. JOSÉ DE RIBAMAR CALDAS FURTADO ${ }^{305}$, sobre caso ocorrido no Estado de São Paulo, menciona também a opinião do Ministro Moreira Alves no Recurso Extraordinário $n^{\circ}$ 183.906-6/SP: em sendo a finalidade vedada pela Constituição Federal (vinculação da receita de impostos), o acréscimo vinculado, por força lógica, também será inconstitucional.

Destarte, nota-se que a vinculação indireta também recai na proibição de se vincular receitas de impostos, não sendo possível utilizar parcela da majoração do imposto para qualquer fim específico, ainda que oriunda de renúncia de receitas com o fito de concessão de benefício fiscal "afetado".

\footnotetext{
${ }^{302}$ ADI-MC 2.848-1/RN. Pleno. Rel. Min. Ilmar Galvão. j. 3 abr. 2003, DJU 2 mai. 2003.

303 Pleno. Rel. Min. Ellen Gracie. j. 22 nov. 2006, DJU 2 fev. 2007: "AÇÃO DIRETA DE INCONSTITUCIONALIDADE. LEI ESTADUAL 12.223, DE 03.1.05. FUNDO PARTILHADO DE COMBATE ÀS DESIGUALDADES SOCIAIS E REGIONAIS DO ESTADO DO RIO GRANDE DO SUL. CONCESSÃO DE CRÉDITO FISCAL PRESUMIDO DE ICMS CORRESPONDENTE AO MONTANTE DESTINADO AO FUNDO PELAS EMPRESAS CONTRIBUINTES DO REFERIDO TRIBUTO. ALEGAÇÃO DE OFENSA AO ART. 155, $\S 2^{\circ}$, XII, G, DA CONSTITUIÇÃO FEDERAL. INOCORRÊNCIA. CAUSA DE PEDIR ABERTA. ART. 167, IV, DA CARTA MAGNA. VINCULAÇÃO DE RECEITA PROVENIENTE DA ARRECADAÇÃO DE IMPOSTO A FUNDO ESPECÍFICO. VEDAÇÃO EXPRESSA.”

${ }^{304}$ Pleno. Rel. Min. Gilmar Mendes. j. 14 jun. 2007. DJU 6 set. 2007.

${ }^{305}$ O problema..., p. 48.
} 


\subsubsection{VINCULAÇÕES TEMPORÁRIAS}

Além das vinculações instituídas a título permanente, poderia haver, como qualquer outra disposição normativa, uma lei que instituísse uma afetação durante determinado lapso temporal, emergindo uma vinculação temporária de receitas. A vinculação de receitas sujeita a limites temporais não encontrará refúgio no texto constitucional se não respeitadas as condições do artigo 167, IV, da Constituição Federal. Entretanto, resta a dúvida se o ato normativo deve ser declarado inconstitucional ou ter a sua eficácia suspensa durante o período determinado.

Instado a se manifestar sobre a vinculação da majoração da alíquota do ICMS, por um ano, à segurança pública no Rio Grande do Sul, o Tribunal de Justiça decidiu que não seria o caso de suspensão da eficácia ou não vigência durante o entrementes mencionado, mas sim de inconstitucionalidade, visto que a finalidade também contaminaria o meio proposto $^{306}$.

Apenas para citar como exemplo no direito comparado, em Portugal, o artigo $7^{\circ}$, item “3” da Lei de Enquadramento Orçamental n 91/2001 define como regra que normas específicas estabeleçam afetações temporárias de receitas, previsão genérica esta inexistente no ordenamento jurídico pátrio:

3 - As normas que consignem certas receitas a determinadas despesas têm carácter excepcional e temporário, em termos a definir em legislação complementar.

Da forma como foi proposto, o dispositivo seria desprovido de eficácia prática, pois permitiria uma transmutação em vinculação permanente de receitas, bastando que o legislativo, periodicamente, ratificasse a vigência deste comando legal, dilatando o seu termo final. Mas tal maleabilidade deve ser vista com desvelo, tendo em consideração o

\footnotetext{
${ }^{306}$ TJ/RS. Apelação Cível 70000262519. $1^{\text {a }}$ Câmara Cível. Rel. Des. Irineu Mariani. j. 23 ago. 2000. DJE 5 dez. 2000: "PRINCÍPIO DA NÃO-VINCULAÇÃO - Lei Estadual que eleva a alíquota do ICMS destinando a receita resultante, durante um ano, a Segurança Pública. Inobservância, porém, pela Lei orçamentária. Derrogação implícita. 1. O art. 167, IV, da CF, consagra o princípio da não-vinculação da receita de impostos, salvo exceções estabelecidas pela própria constituição. 2. Viola tal princípio a Lei Estadual que, num dispositivo, eleva permanentemente a alíquota do ICMS, e noutro destina transitoriamente o total da receita, decorrente do acréscimo, a área da segurança pública, sem reduzir o que foi destinado no exercício anterior. Exegese do art. $2^{\circ}$ da Lei-RS 10983, de 6.8.1997. 3. Tratando-se de afetação apenas transitória, desenha-se a hipótese não como de inconstitucionalidade da elevação permanente, mas de não-vigência durante o período afetado. Não é caso de apenas suspender a vinculação, com preservação da cobrança, porque se o fim conflita com o ordenamento jurídico, o mesmo acontece com o meio que o justifica. 4. Se a Lei orçamentária não cumpriu a vinculação, dissociando a receita originada da elevação de alíquota da finalidade preestabelecida, na prática revogou o vezo do dispositivo legal anterior. Como o fez de modo implícito, não contém norma estranha a previsão da receita e da fixação de despesa, não ferindo, destarte, o art. 165, par. $8^{\circ}$, da CF. 5. Apelo desprovido."
} 
alto risco de desnaturação do instituto, o que obrigaria frequentes escrutínios a fim de verificar se a vinculação obedeceu aos critérios de excepcionalidade e temporalidade que justifiquem a sua criação ${ }^{307}$.

Porém, o risco de desvirtuamento é sempre presente e pode criar tributos com vinculações quase "eternas" a determinadas despesas, tal como o ocorrido com a finada Contribuição Provisória sobre Movimentação ou Transmissão de Valores e de Créditos e Direitos de Natureza Financeira - CPMF: a Emenda Constitucional no 12, de 1996, inseriu o tributo no artigo 74 no ADCT, prevendo como termo final o transcurso de dois anos, que foram prorrogados por mais trinta e seis meses pela Emenda Constitucional no 21, de 1999. Após, a Emenda Constitucional $n^{\circ} 37$, de 2002, prorrogou até o fim de 2004 e a Emenda Constitucional $n^{\circ} 42$, de 2003, mediante o artigo 90 do ADCT, delongou o prazo até 31 de dezembro de 2007, ocasião em que não houve nova prorrogação por conta da não aprovação do Projeto de Emenda Constitucional n n 50, de 2007 (que por sua vez previa a dilação do prazo até 2011).

A despeito das inúmeras inconstitucionalidades apontadas na seara tributária com relação a estas constantes prorrogações - o que não será tratado neste trabalho -, convém ressaltar que a precariedade do aspecto temporal favorece a tentação administrativa em permanecer com a receita vinculada a determinadas despesas. Tal fato faz com que, frequentemente, haja dilações que desvirtuem o caráter temporário e excepcional destas vinculações, prejudicando a sua aplicação em ordenamentos jurídicos instáveis como o brasileiro.

Impende salientar que o desvio de finalidade das vinculações sempre foi o ponto fraco nas tentativas de sua aplicação, o que remete, em verdade, a um desvio de poder do administrador público ${ }^{308}$. Desde o período imperial, com o Fundo de Emancipação dos Escravos, a crítica que se fazia não era quanto à vinculação em si, mas sim ao desvirtuamento do instituto, desrespeitando, inclusive, a própria regra da afetação ${ }^{309}$. Desta feita, toda a utilidade prática da vinculação quedava-se esvaziada, ficando ao sabor da governança orçamentária da época.

\footnotetext{
${ }^{307}$ Ver item 1.3.1 supra sobre o exemplo de uma vinculação para atender às vítimas de tsunami na Ásia.

${ }^{308}$ Segundo JoSÉ CRETELLA JÚNIOR (Do desvio de poder. São Paulo: RT, 1964, p. 27), o "desvio de poder é o uso indevido, que a autoridade administrativa faz do poder que lhe é conferido, para atingir finalidade, pública ou privada, diversa daquela que a lei preceituara."

${ }^{309}$ Cf. RocHA, Ariosto de Rezende. Rendas..., p. 56-57.
} 
Volvendo ao caso da CPMF, na análise da ADI $n^{\circ} 1.640-7 / \mathrm{DF}$, conforme relata FERNANDO FACURY SCAFF ${ }^{310}$, a Corte Suprema decidiu não enfrentar a tredestinação de receitas contida na Lei $n^{\circ}$ 9.438/97 - Lei Orçamentária Anual, na qual previa a destinação de $27,24 \%$ dos recursos da CPMF para o pagamento de dívidas do Governo Federal. Não obstante o texto constitucional registrar expressamente a vinculação da receita para as ações de saúde, o Supremo Tribunal Federal não analisou a constitucionalidade deste ato normativo por ser uma lei de efeitos concretos, não admitindo o controle concentrado.

Ocorre que a correta intelecção da vinculação de receitas depende, precipuamente, do controle pelo Poder Judiciário, para que se evite a má-utilização deste dispositivo pelo Legislativo e Executivo. Sem esta sabatina, não há como assegurar o escopo das vinculações dos desmandos irresistíveis do gestor da coisa pública em vincular e desvincular receitas de maneira indevida.

Passadas estas considerações, poderia haver, no entanto, a vinculação de uma receita temporária a uma operação específica, como, por exemplo, nas despesas de guerra. Porém, há também a mesma falha em dificultar ou minar a fiscalização dos parlamentares sobre estas despesas que são, em regra, inscritas em uma conta especial, apartadas da conta geral do Estado. A justificativa da existência desta falha é que, diferentemente das despesas que necessitam dos recursos oriundos de um fundo único estatal, não há, nas contas especiais, prévia discussão sobre a legitimidade, conveniência e oportunidade, dentre outros aspectos, quando da realização da despesa determinada ${ }^{311}$.

Os trabalhos públicos temporários, para conseguirem sustentar-se e custear as suas despesas também temporárias, necessitam, obviamente, de recursos. Diante disto, pode haver a estipulação da venda de um determinado bem, por exemplo, ou então de empréstimos contraídos, para que seja vinculado diretamente à despesa como justificativa a este tipo de afetação ${ }^{312}$.

Ocorre que, em geral, para casos extraordinários e temporários, o correto é, no nosso entender, prever-se o exercício da competência tributária excepcional mediante a criação de um tributo especialmente para este fim, como ocorre com os impostos extraordinários de guerra - artigo 154, II da Constituição Federal ou então com os empréstimos compulsórios - artigo 148 da Constituição Federal. Nesta esteira, é possível verificar exemplo extraído da recente Constituição do Equador: em seu artigo 273, previu

\footnotetext{
${ }^{310}$ As contribuições..., p. 55.

${ }^{311}$ Cf. SiMÕES, José Martinho. Finanças..., p. 653.

${ }^{312}$ Cf. SIMÕES, José Martinho. Finanças..., p. 653.
} 
que, em caso de catástrofes, poderá haver destinações temporárias e discricionárias aos entes descentralizados ${ }^{313}$.

Assim, constata-se que a afetação temporária para desideratos também provisórios não constitui boa técnica financeira, de forma que o mais correto seria haver a instituição de novos tributos temporários especialmente para estes fins. Isto serviria para facilitar a sua extinção quando do término das razões que ensejaram a sua criação, o que é sobremodo dificultado no caso de vinculação de receitas específicas em virtude das motivações políticas existentes ${ }^{314}$.

\subsection{A “VINCULAÇÃO" DE RECEITAS NO FEDERALISMO FISCAL}

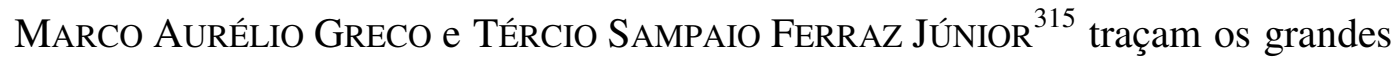
desafios do federalismo fiscal brasileiro; deste rol, três são notadamente importantes: (i) o correto dimensionamento da carta tributária global; (ii) a definição acertada dos encargos públicos e equilíbrio entre receitas e despesa; e (iii) a tentativa de mitigação da guerra fiscal e a competência predatória entre os entes subnacionais, sem que haja a perda da respectiva autonomia.

As repartições de receitas - instrumento jurídico-constitucional do federalismo fiscal brasileiro - possuem papel preponderante nesta dinâmica do federalismo fiscal. É nesta acepção que se fará uma análise da sua aplicação no ordenamento pátrio, cotejando com o uso impróprio do termo "vinculações" para esse fim concebido pela Constituição Federal.

\footnotetext{
${ }^{313}$ Las competencias que asuman los gobiernos autónomos descentralizados serán transferidas con los correspondientes recursos. No habrá transferencia de competencias sin la transferencia de recursos suficientes, salvo expresa aceptación de la entidad que asuma las competencias.

Los costos directos e indirectos del ejercicio de las competencias descentralizables en el ámbito territorial de cada uno de los gobiernos autónomos descentralizados se cuantificarán por un organismo técnico, que se integrará en partes iguales por delegados del Ejecutivo y de cada uno de los gobiernos autónomos descentralizados, de acuerdo con la ley orgánica correspondiente.

Únicamente en caso de catástrofe existirán asignaciones discrecionales no permanentes para los gobiernos autónomos descentralizados (destacou-se).

${ }^{314}$ Ver item 1.3 supra.

${ }^{315}$ Desafios do federalismo fiscal brasileiro. Revista do Instituto dos Advogados de São Paulo. São Paulo. v.1. n.2. jul./dez. 1998, p. 101-02.
} 


\title{
2.2.1. REPARTIÇÃO DE RECEITAS COMO "VINCULAÇÃO" DE RECURSOS PÚBLICOS
}

A consideração da repartição de receitas como "vinculação" para o federalismo fiscal é prática que se pode verificar também na dinâmica financeira de outros Estados. As receitas podem ser usadas no federalismo para garantir o princípio federativo ${ }^{316}$, tendo em vista que a riqueza produzida é una e deve ser repartida entre todos os entes da nação ${ }^{317}$.

WiLliam MCCLEARY ${ }^{318}$, quanto ao sistema colombiano de afetações para repartições no federalismo fiscal, encontra vantagens no estabelecimento destas afetações em virtude do contexto histórico de elevada centralização experimentada por esse país:

\begin{abstract}
A vinculação tornou-se mecanismo para comprometer o governo a continuar atividades específicas apesar do clima político desestabilizado e de evitar elaborar controles orçamentários para prevenir malversação dos fundos. Vinculação na forma de partilha automática de recursos específicos da receita do governo central é uma tentativa de reduzir a extensão da centralização e apoiar atividades nas províncias, e, mais recentemente, municipalidades. (destacou-se)
\end{abstract}

Porém, a abordagem do federalismo fiscal, mesmo à primeira vista causando estranheza em um estudo voltado às vinculações de receitas, é assim tratada nos diversos trabalhos doutrinários $^{319}$. O critério de repartição das receitas governamentais não se coaduna com o conceito de vinculação de receitas, por não coligar a receita a uma despesa predeterminada. Aqui, portanto, a "vinculação" de receitas para o federalismo fiscal aparece em uma forma imprópria, e não no conceito clássico visto até então: neste caso, há o seu uso como fomentadora da cooperação inter-regional e das políticas públicas de cada

\footnotetext{
316 A autonomia dos entes subnacionais é destacada por SÉRGIO PRADO (Equalização e federalismo fiscal: uma análise comparada. Rio de Janeiro: Konrad-Adenauer-Stiftung, 2006, p. 37) no tocante ao grau de controle que é conferido ao ente central na montagem das políticas públicas sociais, inclusive ao se sobrepor aos orçamentos dos entes subnacionais. Segundo o autor, este contexto é verificado, sobretudo, nos gastos sociais, como o FUNDEF (atual FUNDEB) e SUS.

317 Cf. CARretero, Belén García. La financiación de las infraestructuras públicas de países en vías de desarrollo pero con una importante riqueza en recursos naturales: problemas y soluciones. In: FUNDACIÓN PARA LA PROMOCIÓN DE LOS ESTUDIOS FINANCIEROS. Las nuevas fórmulas de financiación de infraestructuras públicas: LI Semana de Estudios de Derecho Financiero. Madrid: Ministerio de Economía y Hacienda - Instituto de Estudios Fiscales, 2008, p. 407. Na Nigéria, por exemplo, 50\% dos recursos oriundos da exploração petrolífera vão para o Estado federal, 30\% para os Estados e 20\% para os governos locais. E os Estados produtores ficam com $12 \%$ desta quantia. Este sistema é concebido como a compensação financeira existente no Brasil.

${ }^{318}$ The earmarking..., p. 99.

319 Este é o tratamento dado pelos economistas. Cf., por exemplo, MENDES, Marcos José. A eficácia da vinculação de recursos no federalismo brasileiro: o caso do FUNDEF. Secretaria do Tesouro Nacional. VIII Prêmio Tesouro Nacional $\quad$ - 2003, p. 7 e $\quad$ ss. Disponível em: $<$ http://www.tesouro.fazenda.gov.br/Premio_TN/VIIPremio/financas/1tefpVIIPTN/mendes.pdf>. Acesso em: 16 out. 2008.
} 
ente federativo. Por conta disto é que, neste trabalho, a expressão é utilizada com ressalvas, com o cuidado de mantê-la entre aspas.

O artigo 167, IV, da Constituição Federal, ao instituir que no ordenamento pátrio são vedadas as vinculações de receitas de impostos, excepciona a repartição de receitas contida no artigo 158 e 159 da Carta. O primeiro trata das receitas que pertencem aos municípios; já o segundo, da transferência dos tributos federais aos Fundos de Participação dos Estados e Municípios.

Em rigor, não se pode considerar que as transferências constitucionais incluem-se no critério de afetações de receitas; mas a ressalva demonstra cristalinamente a forma como o legislador constitucional encarou o sistema de federalismo fiscal brasileiro: insitamente ligado à questão das vinculações.

A lógica do constituinte de 1988 foi conferir às transferências constitucionais o mesmo status de segurança jurídica que gozam as vinculações de receitas, gravando as receitas de determinados impostos de competência dos entes politicamente superiores (União com relação aos Estados e União e Estados com relação aos Municípios) para fomentar o federalismo fiscal cooperativo.

Assim, destina-se percentual ou totalidade da receita de impostos não para custear uma despesa ou operação predeterminada, mas sim para redistribuir aos demais entes federativos. No fundo, o legislador, impropriamente, encarou-a como a vinculação de uma receita a uma operação, id est, o custeio do sistema de descentralização fiscal.

Logo, conforme se depreende da característica principal da vinculação de receitas - elo jurídico entre fonte e destino - percebe-se que há a ausência de um dos fatores: o destino. As repartições federativas podem até gravar determinado percentual de receita para algum ente, porém, ela funciona apenas como um mecanismo para operacionalizar essas transferências. Não há, na outra "ponta" (destino), o estabelecimento de um vínculo para alguma despesa. É o que ocorre, por exemplo, com os Fundos de Participação dos Estados e Municípios - FPE e FPM: o artigo 159 determina que certo percentual de um tributo deva compor o FPE ou FPM, mas não estabelece nenhum gasto ou escopo predeterminado. Essa operação apenas instrumentalizará a repartição de receitas para os diversos entes federativos, que utilizarão esses recursos para suas finalidades específicas, podendo, inclusive, vinculá-los - se não esbarrar no óbice constitucional do artigo 167, IV, da Constituição Federal ${ }^{320}$.

${ }^{320}$ Com relação a essa possibilidade, ver item 2.3.5.3 infra. 
Quanto às despesas obrigatórias, há outro aspecto relevante: elas aparecem como mínimos percentuais, sobre a arrecadação total do Estado, que o ente federativo está compelido a cumprir em determinadas searas sociais, como saúde e educação. Estas despesas, portanto, consideram a receita geral estatal, diferentemente das vinculações, que costumam identificar uma determinada fonte de custeio.

Far-se-á, a seguir, uma diferenciação mais detalhada entre os dois institutos.

\subsubsection{DIFERENÇA ENTRE VINCULAÇÕES DE RECEITAS E DESPESAS OBRIGATÓRIAS}

Se, por um lado, há o problema das repartições de receitas, por outro existem diversos percentuais de despesas obrigatórias contidos no texto constitucional, mormente no tocante à seguridade e outros escopos sociais. HORACIO GUILLERMO CORTi ${ }^{321}$, ao tratar sobre o direito orçamentário substantivo, expõe a terminologia adotada por ADOLFO ATCHABAHIAN para explicar o ordenamento argentino; nesta análise, nota-se o uso sutil dos termos diferentemente do adotado no ordenamento pátrio. Naquele país, os gastos obrigatórios são aqueles cuja origem se dá anteriormente à lei orçamentária, como, por exemplo, os gastos com pessoal ou previdência. Já os gastos facultativos são os previstos pela própria lei orçamentária mediante a respectiva autorização de pagamento.

Em verdade, utiliza-se o critério da rigidez orçamentária abarcando os gastos obrigatórios e as vinculações constitucionais de receitas, formando o que o jurista denominou de gastos juridicamente rígidos. Esta rigidez, por sua vez, avaliaria o nível de maleabilidade na condução das políticas públicas de um determinado governo, cuja mitigação dar-se-ia somente pela alteração da obrigação substantiva ou desconstitucionalização, respectivamente.

Estes gastos costumam prestigiar os direitos prestacionais sociais. Em homenagem a esta garantia, o artigo 2 , B, I da Constituição mexicana de 1917 estabelece que, para garantir o desenvolvimento e a pequena economia indígena, inclusive para a melhora das condições de vida, deverá haver a destinação orçamentária de forma equânime entre os entes locais. O artigo 342 da Constituição do Equador fixa que o Estado asseverará os recursos necessários para o Sistema Nacional de Inclusão e Equidade Social, programa que é destinado a garantir os direitos assegurados constitucionalmente, bem como o

${ }^{321}$ Derecho..., p. 47-49. 
cumprimento dos objetivos programáticos estabelecidos. É importante colocar em destaque também que o mesmo diploma equatoriano, no seu artigo 298, previu as "destinações prévias" de receitas a setores sociais, ressalvando que, além destas, é vedado o estabelecimento de outras consignações:

Se establecen preasignaciones presupuestarias destinadas a los gobiernos autónomos descentralizados, al sector salud, al sector educación, a la educación superior; y a la investigación, ciencia, tecnología e innovación en los términos previstos en la ley. Las transferencias correspondientes a preasignaciones serán predecibles y automáticas. Se prohíbe crear otras preasignaciones presupuestarias.

No caso da Constituição de 1988 no Brasil, houve a definição de diversos mínimos percentuais em algumas áreas a fim de garantir o desenvolvimento nacional. Poder-se-ia classificar esta modalidade como um gasto - ou despesa - mínimo obrigatório, visto que são os destinados a prover as funções essenciais estatais, em contraposição aos gastos facultativos, aqueles relegados à discricionariedade administrativa ${ }^{322}$.

Apesar de comumente haver a utilização das expressões despesa ou gasto mínimo obrigatório, o texto constitucional utiliza o conceito, impropriamente, como sinônimo de vinculação, como ocorreu com a saúde e educação nas suas respectivas emendas constitucionais. Pode-se depreender isto até mesmo da nomenclatura usada na Constituição Federal, mormente no artigo 198, § $3^{\circ}$, II: "os critérios de rateio dos recursos da União vinculados à saúde (...)" e artigo 60, VIII, do ADCT: “a vinculação de recursos à manutenção e desenvolvimento do ensino estabelecida no art. 212 da Constituição Federal (...)" (destacou-se).

RICARDO LOBO TORRES ${ }^{323}$ também propugna pela ocorrência de vinculação de recursos à saúde e a educação, traduzida nas afetações mínimas das receitas de cada ente. Da mesma forma, REgis FERnANDES DE OLIVEIRA ${ }^{324}$ e FERNANDO FACURY SCAFF ${ }^{325}$ entendem haver uma vinculação de despesas para estes setores. Nesta esteira, MISABEL DE ABREU MACHADO DERZI ${ }^{326}$ expressou que entram como exceção ao princípio da não afetação as vinculações parciais das receitas para educação e saúde.

Com a devida vênia a todos os ilustres juristas citados, há, em nossa opinião, um critério diferencial que separa vinculação de receita de despesas obrigatórias. O fator

\footnotetext{
${ }^{322}$ Cf. GriziotTI, Benvenuto. Principios de ciencia de las finanzas. 6. ed., atualizada por Forte, Francesco. Trad. de JARACH, Dino. Bueno Aires: Roque Depalma Editor, 1959, p. 61.

${ }^{323}$ Tratado..., p. 340-43.

${ }^{324}$ Curso..., p. 253 e 264.

${ }^{325}$ Direitos humanos..., p. 35-36.

${ }^{326}$ Art. 40..., p. 294.
} 
preponderante é, justamente, a obrigatoriedade no gasto. A despesa obrigatória, conforme o próprio nome diz, obriga ao gasto no exercício financeiro, diferentemente da vinculação. Esta, por outro lado, apenas estabelece um elo normativo entre uma fonte e destino.

Como exemplo para elucidar a diferença, pode-se cogitar uma hipotética vinculação de $10 \%$ sobre a receita de um tributo incidente sobre combustível e destinada a um fundo de fomento à infraestrutura: nesse caso, não há a obrigatoriedade do gasto anual desses recursos. O ente federativo pode, por exemplo, decidir acumular o montante de verbas no fundo para daqui a dois anos construir uma rodovia transnacional, ou, então, modernizar todos os aeroportos do País. Mas, para tanto, pode ser que precise auferir mais recursos que ultrapassem o exercício financeiro ${ }^{327}$.

Esta é a permissão, aliás, dada pelo próprio parágrafo único do artigo $8^{\circ}$ da Lei de Responsabilidade Fiscal, in verbis:

Art. 8o Até trinta dias após a publicação dos orçamentos, nos termos em que dispuser a lei de diretrizes orçamentárias e observado o disposto na alínea c do inciso I do art. 4o, o Poder Executivo estabelecerá a programação financeira e o cronograma de execução mensal de desembolso.

Parágrafo único. Os recursos legalmente vinculados a finalidade específica serão utilizados exclusivamente para atender ao objeto de sua vinculação, ainda que em exercício diverso daquele em que ocorrer o ingresso. (destacou-se)

$\mathrm{Na}$ Argentina, as exceções do artigo 23 (princípio da não afetação) da Ley de Administración Financiera - LAF são regulamentadas pelo Decreto 2629/1992, o qual prevê uma disposição importante: os saldos remanescentes e não utilizados das afetações deverão ser revertidos no fundo geral unificado do Tesouro ${ }^{328}$. Dessa forma, o ordenamento deste país vislumbra a não utilização dos recursos da vinculação, o que corrobora a sua função de não obrigar ao gasto imediato.

Já a despesa ou gasto obrigatório é, como o próprio nome diz, mandatório: exige que o ente federativo gaste certo percentual de sua receita pública total ou de alguma espécie tributária específica (comumente impostos) em um programa social dentro do exercício financeiro $^{329}$. É facilmente perceptível essa distinção quando a Constituição Federal, por exemplo, inscreve que os entes federativos deverão aplicar anualmente (artigo 212, caput e 198, $\S 2^{\circ}$ ) determinado percentual sobre as receitas em saúde e educação.

\footnotetext{
${ }^{327}$ No direito pátrio, deve haver a observância do artigo $167, \S 1^{\circ}$, da Constituição Federal.

${ }^{328}$ Cf. CORTI, Horacio Guillermo. Derecho..., p. 312.

${ }^{329} \mathrm{O}$ exercício financeiro, no direito brasileiro, coincide com o ano civil, nos termos do artigo 34 da Lei $\mathrm{n}^{\circ}$ $4.320 / 64$.
} 
DIETER BÖS ${ }^{330}$ entende que constitui burla à vinculação a destinação do montante arrecadado e não utilizado na despesa previamente programada. Dois exemplos citados pelo autor externam esta opinião: um se refere a uma lei suíça obrigando que o excesso do imposto sobre a gasolina não utilizado no transporte fosse destinado a uma conta separada para custear excessos de gastos em transporte em anos subsequentes. Outro caso - apenas para menção - ocorreu na Alemanha com um imposto sobre o uso da água, destinado a compensar fazendeiros prejudicados pelas catástrofes ambientais, cuja cláusula de vinculação foi abolida após a verificação do excesso na arrecadação em comparação com as despesas programadas.

Porém, conforme exposto, entendemos que não há a obrigatoriedade ao gasto, de forma que, a nosso ver, a lei suíça supramencionada não seria inconstitucional se existente em nosso ordenamento, uma vez que serviria para reservar recursos para períodos que exigissem maiores dispêndios governamentais. A vinculação é quanto ao gasto, daí que estes recursos não podem ser tredestinados; mas nada impede que sejam colocados em uma conta apartada como uma poupança ${ }^{331}$, garantindo a manutenção de recursos para as despesas determinadas em épocas de maiores necessidades.

É importante também salientar que SUSANNAH CAMIC ${ }^{332}$ entende que os gastos automáticos não se confundem com vinculações, pois é possível a existência delas sem que impliquem despesas automáticas. Estas, por sua vez, não garantem os précomprometimentos a longo prazo por se tratarem apenas de uma conveniência burocrática, e não uma garantia legal para financiar determinado programa.

Tratar-se-á, a seguir, de alguns aspectos das despesas obrigatórias para saúde e educação, a fim de que as diferenças sejam mais bem realçadas.

\footnotetext{
${ }^{330}$ Earmarked..., p. 444.

${ }^{331}$ MAURo SANTOS SILVA (Vinculações..., p. 2-3) expressa que: "Por fim, é relevante mencionar o papel das vinculações de receitas para a formação de poupança compulsória, que constitui a base das linhas de financiamento governamental destinadas ao financiamento do desenvolvimento. Pinheiro (1988:10), ao analisar esta temática, observa que este procedimento garante (i) estabilidade no fluxo de captação de recursos das instituições financeiras que operam com crédito orientado ao desenvolvimento, e (ii) redução dos riscos dessas mesmas instituições financeiras, o que lhes permite maiores oportunidades e menores custos de captação de recursos nos mercados interno e externo." Tratar-se-ia de característica semelhante à constituição de garantias, pelo Poder Público, o que estimularia o crédito público. Ver item 1.6.2 supra.

${ }^{332}$ Earmarking..., p. 68.
} 


\subsubsection{DESPESAS OBRIGATÓRIAS MÍNIMAS PARA A SAÚDE}

A saúde, juntamente com a educação, constitui um dos ramos para os quais o estabelecimento de despesas sociais obrigatórias para políticas públicas comumente recebe apoio e aceitação para contenção do afã da sociedade em se querer, naturalmente, que estes serviços sejam prestados da melhor maneira possível aos indivíduos.

Alguns países, como o Brasil, insculpem constitucionalmente os padrões mínimos na saúde por meio de percentuais. Outros, como a Etiópia, possuem a determinação constitucional de que o governo federal estabeleça os mínimos basilares (artigo 51); porém, nesta nação este mandamento não vem sendo cumprido em virtude, precipuamente, da dificuldade de monitoramento do cumprimento destes desideratos ${ }^{333}$.

O panorama financeiro da saúde brasileira demonstra que, por vezes, a falta de recursos pode não ser a principal justificativa para a insuficiência da prestação deste serviço, e a sua má-gestão costuma ser observada como fator preponderante à precariedade do serviço público.

Constata-se, portanto, que crescem, de forma sobeja, as despesas pátrias destinadas aos serviços de saúde ${ }^{334}$. A Emenda Constitucional $n^{\text {o }} 29$, de 2000, tentando modular alguns efeitos nocivos deste crescimento com a sua correta aplicação, reformulou o sistema sanitário brasileiro. Com a criação do Sistema Único de Saúde - SUS, fazia-se mister a designação da origem dos vultosos recursos que este sistema demandaria. $\mathrm{O}$ artigo 198 da Constituição Federal, em seu parágrafo segundo, indicou, dessarte, os recursos mínimos a serem gastos nesta área.

O artigo 77 do ADCT delimita o percentual que foi aplicado até o ano de 2004 na área da saúde, ocasião em que deveria ter sido editada lei complementar sobre o assunto, mas, até o momento, não foi introduzida no ordenamento jurídico. O parágrafo quarto do mesmo artigo, já prevendo a inércia legislativa, apontou que os limites manter-se-iam os mesmos até a edição da referida lei, a saber:

a) União Federal: no ano de 2000, ter-se-ia como valor-base a quantia empenhada em ações relacionadas à saúde em 1999, acrescido de, no mínimo, 5\%. Após, de 2001 a 2004 - permanecendo tal limite até hoje -, o valor-base seria

\footnotetext{
${ }^{333}$ Cf. Brosio, Giorgio; GuPTA, Sanjeev. Ethiopia. In: TER-Minassian, Teresa (ed.). Fiscal..., p. 518-19.

${ }^{334}$ Cf. REZENDE DA SILVA, Fernando Antonio. Brasil: conflitos federativos e reforma tributária. In: REZENDE DA SILVA, Fernando Antonio (coord.). Desafios do federalismo fiscal. Rio de Janeiro: Editora FGV, 2006, p. 107.
} 
o apurado no ano anterior, corrigido pela variação nominal do PIB. Deste total exposto, $15 \%$ deverão ser aplicados nos Municípios, segundo o critério populacional, em ações e serviços básicos de saúde;

b) Estados e Distrito Federal: 12\% da (i) arrecadação do ITCMD, ICMS e IPVA; (ii) da destinação de recursos do IRRF pagos pelos Estados e seus entes da Administração Indireta e do percentual dos impostos residuais; (iii) do valor de IPI e IR destinado ao Fundo de Participação dos Estados; e (iv) do valor referente à repartição do IPI-exportação do território estadual de origem;

c) Município e Distrito Federal: 15\% da (i) arrecadação do ITBI, ISS e IPTU; (ii) da destinação de recursos do IRRF pagos pelos Municípios e seus entes da Administração Indireta, do montante da repartição do ITR, IPVA e ICMS; (iii) do valor de IPI e IR destinado ao Fundo de Participação dos Municípios; e (iv) do valor referente à repartição do IPI-exportação do território municipal de origem.

Nos Estados Unidos, há sistema interessante de cobertura da saúde pública que, recentemente, tem sido alvo de reformulações pelo Congresso. O Medicare é um programa que destina recursos para tratamento médico a pacientes da terceira idade; há também o Medicaid, que é um programa que destina recursos para indivíduos com baixa renda custearem o respectivo tratamento ${ }^{335}$. É possível verificar, nestes sistemas, que os gastos para saúde acabaram crescendo de forma incontrolável, conforme gráfico sotoposto ${ }^{336}$ :

${ }^{335}$ Informações extraídas, passim, em <http://www.ssa.gov/>. Acesso em: 28 mar. 2009.

${ }^{336}$ Extraído de PENNER, Rudolph G.; KOCH, Julianna. How Much Federal Spending Is Uncontrollable? Tax Notes - The Tax Policy Center, the Urban Institute and Brookings Institution. 16 jul. 2007, p. 195. Disponível em: $<$ http://www.taxpolicycenter.org/UploadedPDF/1001093_federal_spending_uncontrollable.pdf $>$. Acesso em: 28 mar. 2009. 


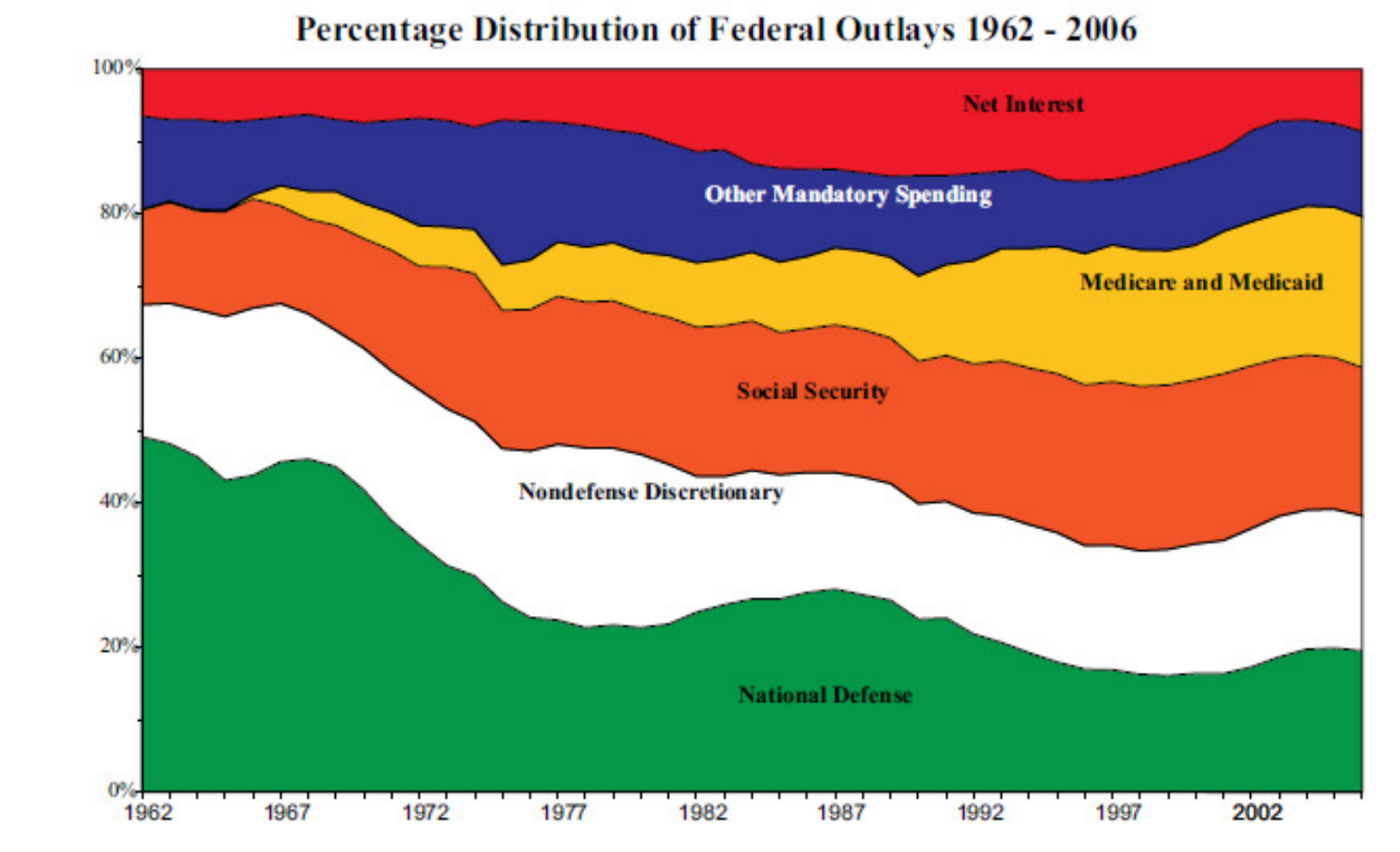

Source: Derived from Congressional Budget Office, "The Budget and Economic Outlook: Fiscal Years 2008 to 2017," Tables E-5, E-7, and E-9.

Depreende-se que a parcela de gastos mandatórios abarca boa parte do desembolso dos recursos federais estadunidenses, a despeito de não haver uma despesa mínima constitucional como no caso brasileiro ${ }^{337}$. Porém, é ressaltado pela doutrina - e passível de observação pelo gráfico - que à proporção que o gasto com defesa nacional foi decaindo, os gastos mandatórios foram aumentando, sobretudo os referentes ao Medicare e Medicaid, sem a contrapartida de diminuição substancial dos encargos tributários ${ }^{338}$.

Assim, os gastos obrigatórios na saúde, tanto no Brasil como em outros países, costumam abarcar boa parcela do orçamento estatal. É neste contexto que surgem as proteções jurídicas para que não haja a sua supressão ou diminuição.

\subsubsection{DESPESAS OBRIGATÓRIAS MÍNIMAS PARA A EDUCAÇÃO}

A educação é, por vezes, setor relembrado para que haja sempre um investimento mínimo necessário de forma a evitar a sua desvalorização política por medidas que supostamente concedam maior resultado eleitoreiro.

${ }^{337}$ Cf. TORRES, Ricardo Lobo. Tratado..., p. 347. O autor aponta o fato de que o ex-presidente estadunidense George W. Bush propôs, para fortalecer a economia, uma diminuição do percentual de gastos com os programas Medicare e Medicaid de 7,4\% para 6,7\%.

338 Cf. PENNER, Rudolph G.; Koch, Julianna. How Much..., p. 195. 
Conforme explica IVES GANDRA DA SILVA MARTINS ${ }^{339}$, é uma área primordial em qualquer Estado, tendo em vista que é o investimento que proporciona o maior retorno à sociedade com o passar dos tempos. Há a formação das futuras gerações que, obviamente, quanto mais qualificadas, mais contribuirão ao desenvolvimento da nação. É por esta razão que o autor entende que qualquer vinculação ou destinação de verbas para a educação é legítima. ÉDÉLESTAND DU MÉRIL ${ }^{340}$, ao tratar sobre a importância filosófica da educação em uma civilização, prega que:

(...) se cada um perseguisse ao acaso o próprio progresso individual, sem unir seus esforços e suas conquistas a uma civilização comum, sua vida não será perdida por sua moralidade, mas ela não contará no desenvolvimento da humanidade.

Diante de sua importância, é possível constatar que as Constituições dos Estados tendem a conceder maior proteção a este valor presente em qualquer civilização. $\mathrm{Na}$ Constituição do Paraguai de 1992, v. g., há o estabelecimento de um mínimo orçamentário na área de educação de $20 \%$, conforme se infere da consignação textual:

Artículo 85 - DEL MINIMO PRESUPUESTARIO

Los recursos destinados a la educación en el Presupuesto General de la Nación no serán inferiores al veinte por ciento del total asignado a la Administración Central, excluidos los préstamos y las donaciones.

A Constituição de El Salvador prescreveu, em seu artigo 61, a necessidade de haver rendas suficientes para o sustento das universidades estatais. Neste diapasão, a Constituição Política do Peru de 1993 disciplinou como prioridade, em seu artigo 16, a dotação prioritária de recursos à educação. E tal disposição não pode, sequer, ser submetida a referendum popular, tendo em tela que o artigo 32 veda expressamente a submissão de normas orçamentárias ao referendo do povo.

A nova Constituição equatoriana ${ }^{341}$ - igualmente na esteira da nova Constituição boliviana (artigos 92 e 93) -, a fim de garantir a autonomia das universidades, vedou

339 e BAStos, Celso Ribeiro. Comentários à Constituição do Brasil. $6^{\circ}$ v. t. II. São Paulo: Saraiva, 1991, p. 346.

${ }^{340}$ Philosophie du budget. Paris: Chez Heideloff et Campé, 1838, p. 359-60.

341 Artículo 355: El Estado reconocerá a las universidades y escuelas politécnicas autonomía académica, administrativa, financiera y orgánica, acorde con los objetivos del régimen de desarrollo y los principios establecidos en la Constitución.

Se reconoce a las universidades y escuelas politécnicas el derecho a la autonomía, ejercida y comprendida de manera solidaria y responsable.

Dicha autonomía garantiza el ejercicio de la libertad académica y el derecho a la búsqueda de la verdad, sin restricciones; el gobierno y gestión de sí mismas, en consonancia con los principios de alternancia, transparencia y los derechos políticos; y la producción de ciencia, tecnología, cultura y arte.

$(\ldots)$ 
qualquer ingerência do Poder Executivo sobre as suas receitas orçamentárias. As universidades bolivianas podem, inclusive, negociar empréstimos dando em garantia os seus bens, desde que haja aprovação por lei.

A Constituição guatemalteca impõe, em seu artigo 84, uma destinação de receitas não menor que 5\% a uma única entidade, qual seja, a Universidad de San Carlos de Guatemala. A Constituição da Nicarágua, por seu turno, segrega $6 \%$ às universidades e centros técnicos de educação públicos (artigo 125). Aqui, é possível destacar o traço de distinção entre despesas obrigatórias e vinculação de receitas para educação: nestes dois casos, há, deveras, a vinculação de um percentual da receita orçamentária para um órgão (universidade), diferentemente do que ocorre com as despesas mandatórias, que obrigam, dentro da arrecadação total, um percentual de gasto em um programa.

Cumpre destacar que a educação, assim como a saúde, é um serviço interfederativo. RiCHARD e PEGgY MuSGRAVE ${ }^{342}$ explicam que, antigamente, nos Estados Unidos, a mobilidade era muito menor do que a existente nos dias de hoje. Por esta razão, os autores concluem que poucos indivíduos quedam-se no mesmo ente local onde obtiveram sua formação educacional. Isto subsidiaria, portanto, programas para a centralização da educação de graus superiores.

No ordenamento pátrio, a educação tem como arrimo constitucional a despesa mínima obrigatória prevista no artigo 212 da Constituição Federal, além do previsto pelas vinculações do Salário-Educação e dos recursos do FUNDEB. Conforme o dispositivo constitucional, a União deve aplicar anualmente, no mínimo, $18 \%$ da receita dos seus impostos, e os Estados, Distrito Federal e Municípios, 25\%, compreendido neste percentual o montante transferido conforme os ditames da participação federativa dos entes. Cumpre mencionar que, além das receitas vinculadas oriundas do Salário-Educação, houve, nos termos da Lei $\mathrm{n}^{\mathrm{o}} 10.260$, de 12 de julho de 2001, alterado pela Lei ${ }^{\circ} 12.202$, de 14 de janeiro de 2010, a formação de um fundo para financiamento da educação superior, denominado FIES - Fundo de Financiamento ao Estudante de Ensino Superior, fomentando o ensino superior à população de menor poder aquisitivo ${ }^{343}$. Neste caso, ocorre uma vinculação de receitas a um fundo para um gasto específico.

La Función Ejecutiva no podrá privar de sus rentas o asignaciones presupuestarias, o retardar las transferencias a ninguna institución del sistema, ni clausurarlas o reorganizarlas de forma total o parcial. (destacou-se).

${ }^{342}$ Hacienda..., p. 847-48.

${ }^{343} \mathrm{O}$ fundo é constituído pelas seguintes receitas, conforme preleciona o artigo $2^{\circ}$ da mencionada lei:

I - dotações orçamentárias consignadas ao MEC, ressalvado o disposto no art. 16; 
O parágrafo primeiro do artigo 212 excetua do cálculo destes percentuais a receita que a União e os Estados devem transferir a título de obrigação constitucional por imposição da repartição federativa das receitas tributárias. Desta forma, incluem-se as receitas recebidas em razão da repartição, porém, excluem-se deste percentual as mesmas receitas que foram transferidas, para que os referenciais numéricos continuem mantidos.

Uma crítica percuciente elaborada por JOSÉ DE RIBAMAR CALDAS FURTADO ${ }^{344}$ é no tocante à porcentagem de recursos destinados para educação nos orçamentos dos municípios. Em estudo analítico, o autor constatou que o percentual de recursos públicos obrigatórios à educação nos municípios maranhenses é de 21,18\% a 63,48\%, variação existente, sobretudo, em virtude do montante transferido pelo FUNDEF.

O autor inclui nesta cifra os $15 \%$ de "vinculação" da receita dos impostos municipais e transferências à saúde, mais as despesas obrigatórias como folha de pagamento e custeio dos encargos sociais para demonstrar a insólita situação de alguns municípios maranhenses de não possuírem, efetivamente, recursos livres para promover outros programas sociais. Como se não bastasse, adicione-se a este contexto a costumeira corrupção existente no País - desta vez exposta por denúncias de fraude no Censo Escolar dos municípios nordestinos - e se chega à caótica situação de se inviabilizar a execução devida do orçamento municipal ${ }^{345}$.

Diante desta realidade fática, as despesas mínimas à educação, assim como as demais, surgem como uma distorção orçamentária, pois o desiderato de se garantir a conservação de um valor nacional é, por vezes, sobrepujado pela burocracia orçamentária que envolve o planejamento governamental. A experiência demonstra que a sobra de recursos fomenta o desejo pelo desvio deste montante, quer para motivos não lícitos como a aplicação em outros setores -, quer para motivos ilícitos - conforme exposto no parágrafo anterior.

II - trinta por cento da renda líquida dos concursos de prognósticos administrados pela Caixa Econômica Federal, bem como a totalidade dos recursos de premiação não procurados pelos contemplados dentro do prazo de prescrição, ressalvado o disposto no art. 16;

III - encargos e sanções contratualmente cobrados nos financiamentos concedidos ao amparo desta Lei;

IV - taxas e emolumentos cobrados dos participantes dos processos de seleção para o financiamento;

$\mathrm{V}$ - encargos e sanções contratualmente cobrados nos financiamentos concedidos no âmbito do Programa de Crédito Educativo, de que trata a Lei no 8.436, de 25 de junho de 1992, ressalvado o disposto no art. 16;

VI - rendimento de aplicações financeiras sobre suas disponibilidades; e

VII - receitas patrimoniais.

VIII - outras receitas. (Incluído pela Lei $\mathrm{n}^{\circ} 11.552$, de 2007).

${ }^{344}$ O problema..., p. 52-53.

${ }^{345}$ Cf. CALDAS FURTADO, José de Ribamar. O problema..., p. 53-54. Acreditamos que o montante de $15 \%$ ao qual o autor se refere seria o relacionado às despesas mínimas obrigatórias para a educação. 
Tendo em vista que, segundo demonstrado pelo autor, grande parte dos municípios possuem mais da metade do orçamento municipal "engessada" a atividades educacionais, é de se esperar que as fraudes surjam, pois uma situação irreal por vezes é retratada: municípios que precisam de recursos para fomentar outras políticas públicas igualmente importantes - como segurança e infraestrutura, por exemplo - têm fatia substancial de recursos atrelada à educação, a despeito de a demanda, por vezes, não justificar tal montante, considerando a densidade populacional destes municípios compreendida na faixa etária escolar.

\subsection{VINCULAÇÃO DE RECEITAS PÚBLICAS COMO GARANTIA}

\subsubsection{CONCEITO DE VINCULAÇÃO COMO GARANTIA}

Semanticamente, o vocábulo garantia origina-se do termo francês garantie, constituindo-se em um ato que assegure uma obrigação determinada, sendo sinônimo de privilégio $^{346}$. Aparece também, em sentido jurídico de direito privado, como gênero de penhor, caução, fiança, sendo um compromisso prestado ao credor para que ele tenha plena satisfação de seu crédito $^{347}$.

Quanto a este aspecto, Sílvio DE SALVo VenosA ${ }^{348}$ lembra que as garantias, apesar de certificarem o cumprimento de uma obrigação, não se confundem com esta. Diante disto, a garantia só pode advir de uma relação jurídica com caráter unilateral que beneficie o credor e o adimplemento de seu crédito.

Por esta razão é que a garantia civil possui caráter acessório com relação à obrigação principal, cujo efeito nada mais é do que, pela regra da especialidade, individualizar um bem para que este responda pela dívida, ao invés da totalidade do patrimônio do devedor. Por decorrência disto, pré-exclui a ingerência de outros credores sobre este bem ${ }^{349}$.

Este último caractere é importante para o foco de estudo no direito financeiro, visto que, na utilização de vinculação de receitas como garantia, haverá a pré-exclusão desta fonte perante futuros débitos do ente público. Diante disto, extrai-se o primeiro

\footnotetext{
${ }^{346}$ Cf. Holanda Ferreira, Aurélio Buarque de. Novo..., p. 835.

${ }^{347}$ Cf. Houaiss, Antonio; VILlar, Mauro de Salles. Dicionário..., p. 1427.

${ }^{348}$ Direito civil. 5. ed. v. 5. São Paulo: Atlas, 2005, p. 539.

${ }^{349}$ Cf. VenosA, Sílvio de Salvo. Direito..., p. 540-42.
} 
cânon, ou seja, não pode haver a dupla vinculação de receitas: uma mesma receita não pode ser vinculada por mais de uma vez para avalizar diferentes débitos.

No direito civil, a garantia real ou pessoal possui um regime que é inaplicável ao direito público ${ }^{350}$, conforme é cediço na doutrina administrativista, dada a impossibilidade de medidas executórias ${ }^{351}$. É importante recordar, neste sentido, a lição de HELY LOPES MEIRELLES $^{352}$ quanto à característica da não oneração dos bens públicos ${ }^{353}$. Há, desta forma, a vedação à oneração de bens públicos em consagração a outras características do regime publicista, tais como a inalienabilidade e impenhorabilidade, incluindo-se, neste balaio, também as rendas públicas - no entender do eminente administrativista.

Ocorre que, em sede de direito financeiro, o regime de precatórios impede a execução da garantia pelo credor, em homenagem aos princípios administrativos supramencionados, adicionado ao princípio da presunção de solvência estatal ${ }^{354}$. Desta forma, a vinculação de receitas não garante (i) a execução forçada da Fazenda Pública, (ii) a satisfação do crédito por via oblíqua que não via Poder Judiciário, ou, ainda, (iii) a autotutela na utilização de créditos retidos - no caso de débitos entre entes federativos ${ }^{355}$. Diante disto, seria, então, uma garantia orçamentária de que estas receitas vinculadas não serão utilizadas para outros fins que não o pagamento da obrigação financeira que a ensejou $^{356}$. As mais recorrentes garantias governamentais na Espanha são as afetações da arrecadação de impostos, que podem ter diversos graus: os mais débeis níveis destas garantias seriam as mencionadas garantias orçamentárias ${ }^{357}$ :

(...) a garantia, e, portanto, a afetação de determinados impostos ao serviço de um determinado empréstimo tem significação meramente orçamentária, expressa somente o compromisso por parte do Estado de destinar no Orçamento a quantidade correspondente ao serviço de juros e amortização. Tal garantia não é uma garantia real

\footnotetext{
${ }^{350}$ Cf. AhumadA, Guillermo. Tratado de finanzas públicas. v. 3. Córdoba: Assandri, 1948, p. 980.

${ }^{351}$ Cf. AtAliBA, Geraldo. Empréstimos públicos e seu regime jurídico. São Paulo: RT, 1973, p. 233 e ss.

${ }^{352}$ Direito administrativo brasileiro. 32. ed. Atualizada por AZEVEDO, Eurico de Andrade; ALEIXO, Décio Balestero; BURLE FILHO, José Emmanuel. São Paulo: Malheiros, 2006, p. 542.

${ }^{353}$ Cf. Venosa, Sílvio de Salvo. Direito..., p. 547. A doutrina civilista também entende que bens inalienáveis não podem ser onerados, como corolário das regras de instituição de direitos reais de garantia.

${ }^{354}$ Cf. GarZA, Sergio Francisco de la. Derecho financiero mexicano. 4. ed. México: Editorial Porrúa, 1969, p. 220. No México, o autor menciona que na exposição de motivos do Código Procesal há a menção da presunção de solvência do Estado, já que é um princípio geral de direito público, dispensando, portanto, garantias especiais.

355 Apenas para curiosidade, a impossibilidade de autossatisfação do crédito também se reflete nas relações internacionais. Com base na opinião de Luís MARIA DRAGO (tese Drago), não há a possibilidade de cobrança coercitiva, por Estados ou entidades estrangeiras, dos créditos devidos por Estado insolvente, sobretudo mediante o uso de armas. A sanção mais efetiva ao Estado devedor é, portanto, a perda de seu crédito perante o mercado internacional. Cf. este histórico em BALEEIRO, Aliomar. Uma introdução à ciência das finanças. 15. ed. Revista e atualizada por CAMPOS, Dejalma de. Rio de Janeiro: Forense, 1998, p. 500-05.

${ }^{356}$ Cf. RIBEIRO, Mauricio Portugal; PRADO, Lucas Navarro. Comentários..., p. 220.

${ }^{357}$ Este ponto será mais bem tratado no item 2.3.4 infra.
} 
que possa ser objeto de execução. É uma garantia cuja execução está confiada à boa-fé do Estado $^{358}$.

Não compreende, portanto, o conceito de vincular com o de dar ou entregar, conforme uma leitura perfunctória do vocábulo pode conduzir equivocadamente o intérprete $^{359}$. Assim, fica vedada a satisfação automática dos débitos (autossatisfação), e o ente respectivo deve reservar os créditos vinculados para o seu pagamento na rubrica orçamentária respectiva, seja perante outro ente federativo ou particulares.

Diante disto, a segunda regra é que a vinculação de receitas não funciona como garantia de autossatisfação de um débito, mas sim como certeza de que os créditos orçamentários vinculados para este fim não poderão ser tredestinados em detrimento do adimplemento da obrigação contraída.

Com isto, conclui-se que a vinculação de receitas, na função de garantia (vinculação-garantia), traduz-se no comprometimento orçamentário de que os recursos deverão ser utilizados para o adimplemento da obrigação contraída, sendo vedadas a dupla vinculação e autossatisfação do débito por meio das receitas garantidas.

\subsubsection{A CREDIBILIDAdE PÚBLICA E A VINCULAÇÃo COMO GARANTIA ESPECIAL DO CRÉDITO}

A afetação das receitas era a regra até o advento da Revolução Francesa ${ }^{360}$. Os credores do rei exigiam-lhe garantias a fim de que se assegurasse o pagamento de seus serviços, de forma que o crédito só era concedido com o seu respectivo fornecimento ${ }^{361}$. É o que relata LEÓN SAY ${ }^{362}$ ao explicar as razões da existência da assignation des recettes.

Continua o autor ressaltando que, após 1789, evoluiu-se para uma nova concepção estatal: todos os recursos deveriam formar uma massa indistinta, sem que um determinado crédito fosse garantido pela afetação de receitas. De fato - relata o autor -, as receitas

\footnotetext{
${ }^{358}$ Apud LAPATZA, José Juan Ferreiro. Curso de derecho financiero español. 24. ed. Madrid: Marcial Pons, 2004, p. 275. O jurista madrileno, no entanto, critica esta citação de CAMPOS por lhe faltar generalidade, i. e., não seria aplicável em todos os casos, principalmente no tocante à impossibilidade de execução.

${ }^{359}$ Cf. esta explicação em ConTi, José Mauricio. Federalismo..., p. 123.

${ }^{360}$ Cf. RochA, Ariosto de Rezende. Rendas..., p. 35. No Antigo Regime, o comum era a consignação de receitas a um fundo especial, destinando-as a despesas específicas. Tal prática favorecia a malversação dos recursos públicos, tendo em vista que havia a gestão múltipla e descentralizada do dinheiro público.

${ }^{361}$ Esta prática continuou a ser desenvolvida nos países mais fracos economicamente, dada a desconfiança dos investidores em inserir capital sem que houvesse a plena garantia de pagamento de seus aportes. Assim, SEBASTIÃo DE SANT’ANNA E SILVA (Os princípios..., p. 27) expõe que as exceções ao princípio da não afetação serviram para “(...) garantir o serviço de juros e amortização dos empréstimos contraídos."

362 Dictionnaire..., p. 611 . Outro sinônimo dado pelo autor é spécialisation. Ver também nota 5 supra.
} 
públicas in totum, a boa-fé do governante e a honra nacional já bastariam como garantia do crédito público. Conclui registrando que esta garantia de consignação de receitas era uma forma especial de chancelar e dar força à credibilidade estatal junto aos seus credores, prática esta comum nos países com mais descrédito ${ }^{363}$.

Com a evolução das teorias financistas, LUIGI EINAUDI ${ }^{364}$ passou a perceber que a dívida pública não deve ser garantida por uma receita específica, mas sim pela lei, confiança e interesse estatal no adimplemento de suas obrigações, que são realizáveis pelo conjunto orçamentário. AlBERTO DEODATO ${ }^{365}$ também expressava que, modernamente, são a fé pública e as dotações orçamentárias que garantem os empréstimos. LUIGI CosSA ${ }^{366}$, nesta senda, explica que os empréstimos podem ser assegurados (i) mediante a vinculação de receitas, prática não mais utilizada (desde o início do século $\mathrm{XX}$ ) por nações com boa capacidade financeira, com exceção em contratos de obras públicas, ou (ii) pela simples fiducia estatal que inspira aos credores.

Logo, esta ideia de vincular receitas como garantia, na visão de GASTON JÈZE ${ }^{367}$, foi abandonada pelos Estados com boa gestão financeira. Contrariamente, explica que o empréstimo (emprunt), em si, serve para cobrir uma despesa determinada. E, desta forma, “(...) o empréstimo tem uma afetação especial”, já que, sem esta vinculação, é um mero método de entesourar recursos. Na França, os orçamentos extraordinários ou contas especiais do Tesouro foram as ferramentas utilizadas à época para a afetação de recursos dos empréstimos públicos.

Diante do exarado, é possível verificar que a vinculação de receitas como garantia especial ${ }^{368}$ ocorria, sobretudo, nas operações de tomada de créditos - concedida pelos entes públicos suspeitos de não adimplirem com suas obrigações. GERALDO

\footnotetext{
${ }^{363}$ Cf. SAY, León. Dictionnaire..., p. 611. Ver nota 361 supra.

${ }^{364}$ Principios de hacienda pública. 6. ed. Trad. de AlgarRA, Jaime; PAREDES, Miguel. Madrid: Aguilar, 1962, p. 375-77.

${ }^{365}$ Manual de ciência das finanças. 13. ed. São Paulo: Saraiva, 1973, p. 254. Assim foram garantidos os empréstimos para o Uruguai em 1846.

${ }^{366}$ Primi elementi di scienza delle finanze. 9. ed. Milano: U. Hoepli, 1905, p. 183.

${ }^{367}$ Cours de science des finances et de législation financière française. 6. ed. Paris: Giard, 1922, p. 240 e 248 e ss.

${ }^{368}$ Há outras formas de garantia nos empréstimos públicos, como, dentre outras, garantias reais, pessoais e contra flutuações econômicas, que não são alvos de estudo deste trabalho. Para este fim, ver FONROUGE, Carlos M. Giuliani. Derecho..., v. II, p. 1034 e ss. Porém, GASTON JèZE (Cours de finances publiques. Paris: Giard, 1928, p. 58) entende que a afetação de receitas seria uma garantia real. FRANCISCO JosÉ CARRERA RAYA (Manual..., p. 181) demonstra que as garantias reais consistiriam na “(...) afetação de um bem ou de uma fonte de riqueza do devedor (...)”, comportando, portanto, uma dupla acepção. Utilizaremos, no entanto, a terminologia do jurista platino citado, sob a premissa de que as garantias reais seriam aquelas relacionadas a um bem da Administração que não as receitas públicas (estas seriam garantias especiais).
} 
ATALIBA $^{369}$ já dizia que o adimplemento estatal adviria da própria confiança que é externada aos credores. Para tanto, a pontualidade e a rigorosidade no cumprimento de suas obrigações - além do decoro e honestidade dos governantes - seriam fatores preponderantes à mantença desta boa fama estatal.

Garantias reais ou pessoais ${ }^{370}$, na visão de GUILLERMO AHUMADA ${ }^{371}$, são utilizadas somente excepcionalmente por demonstrarem suspeitas quanto às finanças estatais de uma nação. Era o que se fazia, antigamente, com a vinculação de receitas ou afetação de joias da Coroa, por exemplo ${ }^{372}$. Segundo o autor, esta prática tendia a desaparecer na Argentina, visto que diminuía a independência estatal ao impossibilitar reformas com relação aos recursos vinculados - principalmente ao se tentar reduzir a respectiva arrecadação, o que influiria negativamente na garantia. Ademais, violava a igualdade estatal perante os credores, criando privilégios desnecessários ${ }^{373}$.

No caso em debate, HeCtor Belisario Villegas ${ }^{374}$ explica que é comum a concessão de garantias aos credores com o fito de tornar as operações de crédito mais atrativas. Tal foi o mote no estado argentino na segunda metade do século XIX ao outorgar "em garantia os ingressos aduaneiros, o produtos das ferrovias, as rendas portuárias e os ingressos de obras sanitárias." 375 Ademais, GUILLERMo AHUMADA ${ }^{376}$ relata as vantagens na afetação de receitas, visto que permite a fiscalização por parte dos credores ou até mesmo o estabelecimento de comissões mistas de credores e devedores. No âmbito internacional, não há como negar a existência de agravamento da soberania de uma nação, além de prejudicar qualquer tentativa de reforma fiscal.

\footnotetext{
${ }^{369}$ Empréstimos..., p. 227 e 230.

${ }^{370}$ Ver nota 368 quanto à terminologia.

${ }^{371}$ Tratado..., p. 979.

${ }^{372}$ Cf. DeODATO, Alberto. Manual..., p. 253, nt. 1: "Assim temos que, no século XIII, Henrique III da Inglaterra enviou a seus credores, como penhor, as jóias da coroa e as relíquias de S. Eduardo. Ainda naquele século, o imperador Balduíno deu a seus credores, como segurança real, a coroa de espinhos, o ferro da lança, a esponja e um pedaço do Santo Lenho. Balduíno XI empenhou a barba. Eduardo II da Inglaterra, no século XIV, deu sua coroa em penhor.”

${ }^{373}$ Cf. AhUMADA, Guillermo. Tratado..., p. 745-46.

${ }^{374}$ Curso de finanzas, derecho financiero y tributario. Con la colaboración de PALACiO, Eduardo S. Caieiro. 9. ed., Buenos Aires: Editorial Astrea, 2007, p. 121.

${ }^{375}$ Cf. Fonrouge. Carlos M. Giuliani. Derecho..., v. II, p. 1036. Cf. também, neste sentido, VILLEGAS, Hector Belisario. Curso..., p. 121 e RodRIGUEZ Rossi, Victor Ernesto. El crédito público: efectos y empleo. Buenos Aires: Abeledo Perrot, 1981, p. 56.

${ }^{376}$ Tratado..., p. 981.
} 
Na Espanha há ainda a figura dos avales públicos ${ }^{377}$ para garantir as obrigações contratuais, cujos limites deverão constar na lei orçamentária. JOSÉ JUAN FERREIRO LAPATZA $^{378}$ expõe que a Constituição espanhola prescreve a necessidade de estrito cumprimento das obrigações relativas à dívida pública, obrigando Legislativo e Executivo a cumprir com tais deveres, sob pena de inconstitucionalidade. Assim, o Estado garantiria “(...) sua dívida pública fundamentalmente, insistimos, com a força de seu próprio crédito, da confiança que inspira aos seus credores." Na insuficiência destas razões é que aparecem as garantias especiais, na visão do jurista espanhol.

Questão interessante é quanto à utilização do excesso de arrecadação vinculada para outros fins que não o da vinculação ao pagamento da dívida. GUILLERMo AHUMADA $^{379}$ explica que um dos inconvenientes da afetação para os empréstimos públicos é que não pode haver o uso do excedente para outras despesas.

Neste caso, entendemos que caso haja a vinculação de receitas ao pagamento da dívida, esta afetação não poderia ultrapassar o valor do crédito mais a remuneração pelo capital estabelecida no contrato. Assim, na hipótese de arrecadação suficiente, deverá haver a quitação antecipada da dívida pelo saldo devedor (ou o provisionamento dos recursos, caso não seja possível esta antecipação) e o excedente ser colocado em disponibilidade orçamentária para utilização nas despesas gerais - salvo se houver disposição expressa em contrário. Isto porque se a garantia serve-se ao pagamento da dívida, não há razão para que este excedente fique entesourado, uma vez que o valor da arrecadação descontado o excedente já garantiu - ou garantirá - o pleno adimplemento contratual.

\subsubsection{A JUSTIFICATIVA DE SEU USO}

As consignações podem reforçar o crédito público ao garantir aos credores o pagamento dos respectivos créditos de forma tempestiva ${ }^{380}$. É daí o brotamento da ideia de que as vinculações podem ser constituídas como um plus nas operações estatais de crédito, elevando a credibilidade estatal com relação ao seu crédito.

\footnotetext{
${ }^{377}$ Segundo FERNANDO PÉREZ RoYo (Derecho financiero y tributario: parte general. 9. ed. Madrid: Civitas, 1999, p. 414-15), "tratam-se de operações financeiras desenvolvidas pelo Estado ou por seus organismos autônomos para afiançar as obrigações derivadas de crédito concertadas por outras pessoas públicas ou privadas".

${ }^{378}$ Curso ..., p. 274-75. Cf. também CARRERA RAYA, Francisco José. Manual... , p. 181.

${ }^{379}$ Tratado..., p. 982.

${ }^{380}$ Cf. Simões, José Martinho. Finanças..., p. 650.
} 
Eis porque LOUIS TROTABAS ${ }^{381}$ entende este tipo de vinculação como exceção à regra geral de que as receitas são desvinculadas pela própria natureza das despesas. Funcionam, deveras, como um:

(...) procedimento jurídico do tipo fiança ou garantia. É com base nisto que ela se verifica frequentemente, ligada às operações de crédito público, quando o Estado não goza de crédito suficiente: é então compelida a garantir o serviço de seus empréstimos mediante a afetação de uma receita (...) (destacou-se)

As técnicas que podem ser utilizadas - consoante JosÉ MARTINHO SIMÕES ${ }^{382}$ são pela consignação direta de receitas aos credores, que poderão cobrá-las com o abatimento no empréstimo, ou, então, pela constituição de um fundo $^{383}$ particular especial, com a respectiva afetação de seu produto. A gestão deste fundo ficaria incumbida ao Estado, aos próprios credores, ou, ainda, a ambos. É o que prescreve, e. $g$., o artigo $8^{\circ}$, II da Lei n ${ }^{\circ} 11.079 / 04$, a lei das Parcerias Público-Privadas (PPPs), quando prevê a possibilidade de instituição de fundos especiais. O caput do artigo 16 da mencionada lei vislumbra, também, o FGP - Fundo Garantidor das PPPs -, cuja representação é feita por instituição financeira controlada pela União, conforme prescrição do artigo $17^{384}$.

O reforço ao crédito público nesta modalidade é visto como inconstitucional pela doutrina administrativista brasileira. Ao comentar a questão dos Fundos Garantidores das PPPs, CELSO ANTÔNIO BANDEIRA DE MELlo ${ }^{385}$ coloca em xeque a sua constitucionalidade à luz dos princípios administrativos da impessoalidade, igualdade e moralidade. Aqui, todavia, diferenciamos dois momentos das relações dos particulares com a Administração Pública: a existência de obrigação de pagar por obrigação contratual ou por decisão judicial. Estas nuanças serão destacadas posteriormente ${ }^{386}$.

A doutrina argentina, por exemplo, ao apontar as exceções doutrinárias ao princípio da não afetação de receitas, reserva especial destaque ao mencionar as garantias especiais que o crédito público pode possuir:

$1^{\circ}$ ) Quando se toma um empréstimo para fazer frente a um determinado gasto, o produzido de tal empréstimo se afeta, seja por uma decisão formal do legislador, seja por forças das circunstâncias do referido gasto.

\footnotetext{
${ }^{381}$ Finances..., p. 145.

${ }^{382}$ Finanças..., p. 650.

${ }^{383} \mathrm{O}$ uso dos fundos como instrumentos das vinculações será tratado no item 4.1 infra.

${ }^{384}$ Com relação ao Fundo Garantidor das Parcerias Público-Privadas, ver CARVALHO, José Augusto Moreira de. As Parcerias Público-Privadas e a atividade financeira do Estado. Dissertação (Mestrado em Direito) Faculdade de Direito, Universidade de São Paulo, 2006, p. 159 e ss.

${ }^{385}$ Curso..., p. 774 e ss.

${ }^{386}$ Ver item 2.3.4.3 infra.
} 
$\left.2^{\circ}\right)$ Para os Estados com pouco crédito é difícil obter empréstimos externos. Os credores impõem, então, que se afetem garantias especiais aos serviços, e entre tais garantias costumam exigir a aplicação de determinadas rendas fiscais, com o qual o princípio da não afetação também se vulnera.

$3^{\circ}$ ) $\mathrm{O}$ produzido de certas taxas se afeta por diferentes leis a certos serviços personalizados, como, por exemplo, ocorre quando se destina a certo incremento industrial o produzido de determinados impostos sobre o consumo ${ }^{387}$. (destacou-se)

Percebe-se, destarte, ser uma modalidade vetusta de reforço à confiabilidade do crédito público, mas ainda aplicável hodiernamente. Ressalta JOSÉ MARTINHO SIMÕES ${ }^{388}$ que tal prática costumava ocorrer em nações pouco prósperas à época, como a Turquia, Grécia, Egito e inclusive Portugal; esta era a regra para que houvesse a facilitação na contração de dívida pública por estes Estados com maior descrédito.

Existem, contudo, certos inconvenientes nesta prática, conforme apontado pelo jurista $^{389}$. Há um prejuízo na liberdade de negociação e reforma dos serviços correlatos à receita afetada, visto que, em respeito ao direito adquirido e ato jurídico perfeito oriundos da contratação do empréstimo público, só poderia haver alterações com o mútuo acordo entre os credores. Outro problema concerne aos limites da soberania estatal, que é relacionado à liberdade negocial exposta: o Estado que quiser modificar a vinculação originalmente instituída teria tal ato interpretado, pelos credores, como uma forma de burlar as garantias concedidas, elevando o risco atinente a este crédito e na tomada de créditos supervenientes, o que acarretaria condições mais desfavoráveis de contratação. Por fim, há a questão de que, com a excessiva consignação de receitas para reforçar o crédito, a população consegue perceber quais são as prioridades estatais e quais não são, diminuindo, destarte, a credibilidade estatal nos setores relegados.

Em razão disto, JosÉ MARTINHO SIMÕES ${ }^{390}$ veementemente desaconselha a utilização da vinculação de receitas como forma de reforço à credibilidade estatal, visto que, em tese, "todas as dívidas do Estado são igualmente sagradas, e por isso todas devem ser cumpridas com o mesmo escrúpulo e pontualidade". Entende o autor que todas as dívidas estatais estão no mesmo patamar, desde, por exemplo, dívidas internacionais a precatórios de pequeno valor, e que as vinculações feririam esta isonomia.

Logo, a premissa do uso das vinculações de receitas como justificativa a uma concessão de maior força e confiabilidade ao crédito público, fomentando a solvência

\footnotetext{
${ }^{387}$ Cf. JuAnO, Manuel de. Curso..., p. 384. Tradução do original.

${ }^{388}$ Finanças..., p. 650.

${ }^{389}$ Cf. estas observações em SIMÕES, José Martinho. Finanças..., p. 651.

${ }^{390}$ Finanças..., p. 652.
} 
estatal, é equivocada em face do pressuposto de que o Estado deve honrar com seus débitos indistintamente e em face de qualquer credor.

\subsubsection{EVOLUÇÃO DA APLICAÇÃO NO BRASIL}

A origem da vinculação de receitas no Brasil apresenta um caractere importante. Ao invés de exsurgir com o conceito estrito de elo entre a receita e despesa, apareceu como forma de conceder maior garantia aos credores estatais, mediante a instituição de fundos especiais. Assim aconteceu no período imperial para que, com as vinculações, houvesse uma inspiração de confiança aos países estrangeiros, transmutando, dessarte, a exceção em $\operatorname{regra}^{391}$.

Misabel de Abreu Machado Derzi ${ }^{392}$ comenta que as exceções ao princípio geral orçamentário da não vinculação surgiram “(...) exatamente no seio dos empréstimos públicos, com o objetivo de reforçar o crédito dos entes estatais empobrecidos e tiveram como meta evitar as garantias reais." (grifos do original)

JOÃo PEDRO DA VEIGA FILHO ${ }^{393}$ já advertia quanto à desnecessidade lógica do uso afetado de receitas públicas como garantias, bem como na utilização recorrente da aplicação especial de receitas. Ao mencioná-la, o autor desfere, com acinte, uma importante crítica a esta prática corriqueira da Administração Pública:

Sob o ponto de vista moral denuncía officialmente a inobservancia do orçamento, a qual só explica e legitíma essa necessidade de ser, especificada a applicação das verbas da receita; além disso, attesta a fraqueza e o declinio do credito do Estado que, para mais segura e effectiva solução de seus compromissos, fica, por semelhante regimen, coarctado e adstricto a expediente tão censuravel quão offensivo ao melindre nacional. A receita publica, diz Boiteau, a boa fé do governo e a honra nacional respondem, sem duvida, melhor pelos encargos e compromissos do que uma simples garantia especial. Uma subdivisão do penhor não póde, com effeito, valer mais do que o penhor todo inteiro. No Brazil, o systema predominante é o da unidade orçamentaria, todavia, tanto no antigo regimen como no actual, algumas rendas tem tido applicação especial e são (sic) destinados a certos serviços. (grifos do original)

Apesar destas considerações, no Brasil sempre se vislumbrou a vinculação de receitas como uma garantia, quer para os investidores estrangeiros, quer por um ente federativo perante outro (em regra, pela União Federal). Esta modalidade - não aplicável hodiernamente nos países ditos mais desenvolvidos - reconstituiu os embates doutrinários

\footnotetext{
${ }^{391}$ Cf. RochA, Ariosto de Rezende. Rendas...p. 60-61.

392 Arts. 40..., p. 294.

${ }^{393}$ Manual da sciencia das finanças. 2. ed. São Paulo: Espindola, 1906, p. 262.
} 
acerca de sua possibilidade com o exsurgimento da Lei de Responsabilidade Fiscal e a Lei das Parcerias Público-Privadas.

Neste ponto, a questão do controle e interferência à soberania e autonomia também são suscitados, inclusive no direito comparado. Segundo observação de VICTOR ERNESTO RODRIGUEZ ROSSI ${ }^{394}$, o controle destas receitas pode quedar-se com (i) o país credor - como ocorreu em empréstimos a nações da América Central no século XIX; (ii) comissões especiais ad hoc, ocorridas na Alemanha em 1924; e (iii) organismos internacionais - como a Sociedade das Nações, nos empréstimos para a reconstrução da Áustria e Hungria no pós-Primeira Guerra Mundial ${ }^{395}$.

Quanto a esta última característica, GASTON JÈZE ${ }^{396}$ entende que a preferência dos organismos internacionais na vinculação de receitas para garantia dos empréstimos públicos deveu-se, sobretudo, à preocupação de que houvesse uma gestão pública eficiente e responsável, o que, apesar de seus aspectos benéficos, não deixa de imprimir certo desprestígio quando à capacidade de autogestão destas nações. Nesta esteira, a doutrina francesa previa, como exceção à regra da não afetação $^{397}$, a vinculação de receitas para fazer frente ao risco de Estados mau pagadores. De fato, conforme já ventilado, a garantia advinda pela vinculação servia como facilitadora aos empréstimos públicos externos ${ }^{398}$.

No ordenamento brasileiro, as garantias cingem-se (i) às relações creditícias entre Estado (dois ou mais entes federativos) e particulares, ou (ii) entre entes federativos (relações interfederativas). Neste último caso, aplicam-se os dispositivos insculpidos nos artigos 29, IV e 40 da LRF, com a criminalização da conduta ímproba, no caso de prestação de garantia graciosa, mediante o artigo 359-E do Código Penal ${ }^{399}$. AMIR

\footnotetext{
${ }^{394}$ El crédito..., p. 56.

395 CARlos M. GiUliani Fonrouge (Derecho..., v. II, p. 1036-37) explica que a eficácia destas garantias requereria uma fiscalização efetiva. Desta forma, a criação destes "controles financeiros internacionais", por meio de comissões, por exemplo, era imperiosa. Relata o autor que os Estados Unidos, para manter a sua "política não intervencionista", controlava desta maneira os recursos afetados como garantia de empréstimos dos países da América Central.

${ }^{396}$ Cours de finances..., p. 58.

${ }^{397}$ Cf. Duverger, Maurice. Finances..., p. 321. O autor ressalta, ao listar as principais críticas doutrinárias à não afetação, a existência de afetação de certas garantias para os empréstimos públicos contraídos.

${ }^{398}$ Cf. LAFERRIÈRE, Julien; WALINE, Marcel. Traité..., p. 96-97: "Os empréstimos públicos colocam ainda, sob um outro ângulo, a questão da afetação de receitas. Nos Estados onde o crédito é débil, pode ser difícil de se obter empréstimos, especialmente empréstimos no exterior, se não houver aos credores garantias de pagamento da remuneração e reembolso do capital; eis a existência das estipulações de afetação de receitas no empréstimo ao serviço de adimplemento da dívida (por exemplo, mediante afetação de receita fiscal determinada)"

${ }^{399}$ Cf. comentários de PAZZAGlini FILho, Marino. Crimes de responsabilidade fiscal: atos de improbidade administrativa por violação da LRF. 3. ed. São Paulo: Atlas, 2006, p. 84.
} 
ANTÔNIO KHAIR ${ }^{400}$ estimou, ainda, que a concessão de garantias pode envolver pelo menos seis transgressões à Lei de Responsabilidade Fiscal. A inobservância do disposto no artigo 40, caput, supramencionado pode ensejar, por exemplo, a cassação do mandato com base no artigo $4^{\circ}$, VII, do Decreto-lei 201/1967 e, caso a inobservância ocorra com relação ao $\S$ $1^{\circ}$ do artigo 40, poderá o gestor público incorrer na conduta do citado artigo 359-E e deverá suportar a respectiva responsabilização criminal.

Doutrinariamente, com relação à Lei de Responsabilidade Fiscal, MisABEL ABREU MACHADO DERZI ${ }^{401}$ expõe que:

Garantias e contragarantias podem ser oferecidas pelos entes da Federação uns aos outros para fortalecer o crédito, quer a obrigação financeira ou contratual (a ser garantida) se destine a constituir dívida fundada ou flutuante.

(...)

Garantia é expressão ampla, que inclui qualquer caução destinada a conferir a segurança ao pagamento, quer oferecida pelo próprio devedor, em adição à garantia genérica que o seu próprio patrimônio configura, quer por terceiro, estranho à obrigação principal. (destaques do original)

A Resolução Senatorial $n^{\circ} 48$, de 2007 , também conceitua, em seu artigo $9^{\circ}$, § $1^{\circ}$, a concessão de garantia como “(...) fianças e avais concedidos direta ou indiretamente pela União, em operações de crédito, inclusive com recursos de fundos de aval, a assunção de risco creditício em linhas de crédito, o seguro de crédito à exportação e outras garantias de natureza semelhante que representem compromisso de adimplência de obrigação financeira ou contratual."

A despeito dessas regulamentações, faz-se imperioso repisar que tal instituto é prescindível, só havendo sentido quando o país é permeado por severas oscilações políticas e desconfianças perante os seus credores - tal como ocorreu historicamente no Brasil, conforme expôs Sebastião de SANT'AnNA E Silva ${ }^{402}$. Inclusive, JAMES Giacomoni ${ }^{403}$ explica que os municípios costumavam, no passado, utilizar a receita de impostos como garantia nos empréstimos, fato este que em 1988 veio a ser vedado com a instituição do artigo 167, IV, in fine.

\footnotetext{
${ }^{400}$ Lei de Responsabilidade Fiscal: as transgressões à Lei de Responsabilidade Fiscal e correspondentes punições fiscais e penais. Brasília: MPOG/BNDES/ENAP, 2000, p. 37 e 104.

${ }^{401}$ Arts. 40..., p. 285.

${ }^{402}$ Os princípios..., p. 28: "Outras vêzes, tornou-se necessário garantir, à vista da instabilidade dos governos e das oscilações da política dos parlamentos, a continuidade de determinados programas e empreendimentos governamentais de duração excedente ao exercício financeiro. A vinculação de certas receitas ao financiamento dêsses projetos e empreendimentos garantiria sua integral execução, a salvo das oscilações da vida política."

${ }^{403}$ Orçamento..., p. 76.
} 
Diante disto, entendemos modernamente como dispensável este tipo de vinculação - justificado somente quando um Estado demonstra, reiteradamente, certa relutância em adimplir com seus débitos. Contudo, ressalvado o mérito da vinculaçãogarantia, a fim de compatibilizá-la com a análise jurídica do instituto no País, inclinamonos a aceitá-la por ser um mecanismo transitório visando a, futuramente, restar abandonado em prol da confiança pública que o Estado brasileiro deve inspirar aos credores - privados e públicos.

Para vinculações na função de garantia, os dispositivos regentes no ordenamento são os contido na Lei $\mathrm{n}^{\mathrm{o}}$ 11.079/04 - no caso de garantias aos particulares - e o artigo 167, $\S 4^{\circ}$, in fine, CF e artigo 40, $\S 1^{\circ}$, II, LRF e as regulamentações por resoluções senatoriais no caso de garantias interfederativas. Passar-se-á, então, a analisar as vinculações de receitas aos entes privados e, posteriormente, as vinculações nas relações interfederativas.

\subsubsection{A VINCULAÇÃO-GARANTIA DA LEI Nº 11.079/05}

\subsubsection{IMPORTÂNCIA DO DISPOSITIVO NO ORDENAMENTO}

A Lei das Parcerias Público-Privadas (PPPs) inaugurou, em seu artigo $8^{\circ 404}$, I, a vinculação de receitas como garantia a particulares no ordenamento intestino, conforme se observa:

Art. $8^{\text {o }}$ As obrigações pecuniárias contraídas pela Administração Pública em contrato de parceria público-privada poderão ser garantidas mediante:

\footnotetext{
404 MAURicio PORTUGal Ribeiro e LuCAS NAVARRo PRAdo (Comentários..., p. 211-16) apresentam a discussão acerca da constitucionalidade deste artigo em face do artigo 163, III, da Constituição Federal, cuja regulamentação sobre "concessão de garantias pelas entidades públicas" deveria, em tese, ser veiculada por lei complementar. Os autores, no entanto, entendem que o comando em comento é restrito a normas de finanças públicas aos entes federativos, com o fito de garantir a responsabilidade fiscal destes entes. Diante disto, o artigo 40 da Lei de Responsabilidade Fiscal já atenderia a esta finalidade e, por consequência, o artigo $8^{\circ}$ da Lei $\mathrm{n}^{\circ} 11.079 / 04$ poderia ser veiculado por lei ordinária, visto que apenas instrumentalizaria a prestação das garantias. Sob uma análise da Exposição de Motivos Interministerial n ${ }^{\circ}$ 106/MOG/MF/MPAS, de 13 de abril de 1999, justificadora da Lei de Responsabilidade Fiscal, percebe-se, em seu item 23, que o artigo 40 adveio com clara intenção de uma gestão físcal responsável, salvaguardando a "adimplência do garantido" pelos entes públicos. O artigo 29, IV, veio a definir a concessão de garantias neste sentido: "concessão de garantia: compromisso de adimplência de obrigação financeira ou contratual assumida por ente da Federação ou entidade a ele vinculada". Desta forma, perante estas considerações doutrinárias e normativas exaradas, seguimos no sentido da argumentação ora exposta, dado que a Lei de Responsabilidade Fiscal já teria sido introduzida para regular estes limites e condições. A norma do artigo $8^{\circ}$, I, da Lei $\mathrm{n}^{\circ}$ 11.079/04, destarte, não necessitaria ser veiculada por lei complementar, razão pela qual partiremos da premissa de que o artigo é constitucional, ao menos sob esta ótica formal.
} 
I - vinculação de receitas, observado o disposto no inciso IV do art. 167 da Constituição Federal;

Conforme sobredito, é utilizada atualmente nas contratações públicas como um dispositivo garantista que JUAREZ FREITAS ${ }^{405}$ nomeia de blindagem ou garantias especiais. Sua função assecuratória faz com que o poder público resolva prontamente o problema de crédito junto ao parceiro privado. É perceptível que a vinculação de receitas tem sido usada como função garantidora dos contratos diante da justificativa exarada no Projeto de Lei $\mathrm{n}^{\circ}$ 2.546/2003 - o qual originou a Lei das Parcerias Público-Privadas. Nas razões endereçadas ao Presidente da República pelo Ministério do Planejamento e pelo Ministério da Fazenda, menciona-se que:

Merecem igual destaque, no âmbito do projeto e do capítulo segundo, os instrumentos de remuneração e garantia previstos, como a (...) a admissão da vinculação de receitas e instituição de fundos especiais, desde que previsto em Lei específica $\left(\operatorname{art.} 8^{\circ}\right) ;(. . .)^{406}$ (destacou-se)

A própria Lei manteve a redação original do projeto, nomeando o Capítulo III donde se vislumbra a possibilidade de vinculação de receitas - como "Das Garantias". A intenção de utilizar as vinculações para reforço à credibilidade do crédito público é, portanto, explícita na Lei das Parcerias Público-Privadas.

Aparece tal dispositivo na qualidade de verdadeiro mecanismo de proteção contratual em face da probabilidade da inadimplência pública, conforme apontado por VERA MONTEIRO ${ }^{407}$. A autora menciona, inclusive, as nítidas intenções legislativas em se dar cada vez mais prioridade ao adimplemento estatal destes contratos.

É importante mencionar que a razão do solevantamento das vinculações de receitas com a função de garantia nas concessões - cuja vinda no ordenamento jurídico

\footnotetext{
${ }^{405}$ Parcerias Público-Privadas (PPPs): características, regulação e princípios. Interesse Público. Sapucaia do Sul, RS. v.5. n.29. jan./fev. 2005, p. 24 e ss.

406 Exposição de Motivos n ${ }^{\circ}$ 355/2003/MP/MF, de 10 de novembro de 2003. Disponível em: $<$ http://www.camara.gov.br/sileg/integras/182910.pdf> $>$. Acesso em: 20 out. 2008.

${ }^{407}$ Legislação de Parceria Público-Privada no Brasil - aspectos fiscais desse novo modelo de contratação. In: SundFeld, Carlos Ari (coord.). Parcerias Público-Privadas. São Paulo: Malheiros, 2005, p. 93 e 98-99: "Quanto às garantias do particular e à forma de proteção de seu crédito, cogitou-se, em algumas das minutas que antecederam a lei federal, de dar preferência de pagamento a contratos de PPP. Depois de algum debate público esta regra acabou não sendo incorporada em texto algum, nem mesmo o federal, com exceção do de Santa Catarina, cujo art. $5^{\circ}, \S 3^{\circ}$, prevê que 'a liberação dos recursos orçamentário-financeiros e os pagamentos efetuados para cumprimento do contrato com o parceiro privado terão precedência em relação às demais obrigações contratuais contraídas pela Administração Pública, excluídas aquelas existentes entre entes públicos e observado o disposto no art. $9^{\circ}$ da Lei Complementar federal n. 101, de 4 de maio de 2000'."
} 
vicejou por imperiosa necessidade de se dar maior credibilidade ${ }^{408}$ ao parceiro privado advém da própria natureza da Administração Pública em menoscabar os seus débitos vincendos, o que acarreta, por vezes, complicações financeiras na hora do cumprimento da obrigação de pagar.

Mauricio Portugal Ribeiro e LuCAS NAVARro PRADO ${ }^{409}$, nesta esteira, entendem que:

(...) não fosse a tradição de mal-pagador (sic) do Governo brasileiro, seriam desnecessárias as garantias do parceiro público. Como se não bastasse, é imperioso lembrar que, numa situação em que as garantias estejam ausentes, (...) terão que enfrentar o procedimento dos precatórios se não houver o regular pagamento da obrigação pecuniária da Administração.

Diante disto, ressaltam que o regime de precatórios desestimularia ou até mesmo inviabilizaria a contratação pelos parceiros privados em determinados projetos. As garantias surgiriam como uma diminuição do risco político ${ }^{410}$ ao contratante, o que redundaria em melhores propostas à Administração Pública. Para os juristas, no entanto, a única garantia que poderia ter certa margem de segurança ao parceiro privado seria os fundos garantidores, dado que a vinculação de receitas poderia ser sujeita a decretos de

\footnotetext{
${ }^{408}$ Cf. RiBeIRO, Mauricio Portugal; Prado, Lucas Navarro. Comentários..., p. 205-06. Os autores entendem, inclusive, que esta garantia na contraprestação pública é o ponto nevrálgico do sucesso das contratações na modalidade de PPP.

${ }^{409}$ Comentários..., p. 206.

410 Cf. RiBeIRo, Mauricio Portugal; PrAdo, Lucas Navarro. Comentários..., p. 208-9. Para os autores, o chamado risco político subdivide-se em outros dez sub-riscos: "(i) risco de não haver previsão orçamentária para o pagamento das contraprestações públicas; (ii) risco de o órgão contratante, apesar da previsão orçamentária, não realizar o empenho em face do decreto de contingenciamento; (iii) risco de o órgão contratante, por vontade própria, simplesmente não empenhar o montante destinado ao pagamento das contraprestações públicas, a despeito do adimplemento das obrigações do parceiro privado e da ausência de contingenciamento; (iv) risco de que, uma vez empenhada, o órgão contratante não proceda à liquidação da despesa; (v) risco de, mesmo empenhada e liquidada, a despesa não ser efetivamente paga, por ultrapassar o limite financeiro anual para pagamentos, sendo contabilizada como "Restos a Pagar" para o ano seguinte; (vi) risco de o órgão contratante, por vontade própria, simplesmente não realizar o pagamento, embora lhe seja possível em face do limite financeiro estabelecido, com a conseqüente contabilização em "Restos a Pagar" para o exercício seguinte; (vii) risco de se encerrar o exercício financeiro sem o efetivo pagamento, por ausência de tempo hábil para as providências necessárias, sendo contabilizada também como "Restos a Pagar"; (viii) risco de não-pagamento de despesas contabilizadas em "Restos a Pagar" até 31 de dezembro do ano subseqüente, com o conseqüente cancelamento da inscrição; (iv) risco de, em caso de cancelamento da inscrição em "Restos a Pagar", não-previsão de dotação orçamentária destinada a despesas de exercícios anteriores; e, por fim, (x) mesmo havendo a previsão por último referida, risco de impossibilidade de pagamento em face de sujeição ao limite financeiro de pagamentos.”. Sob outra ótica, merece destaque a posição de MARTins, Vinicius Aversari; Andrade, Maria Elisabeth Moreira Carvalho. Contabilidade de contratos de parcerias público-privadas: uma abordagem à luz das normas internacionais do IASB. Contabilidade, Gestão e Governança. Brasília. v. 12. n. 1. jan./abr. 2009, p. 15. O risco de falta de pagamento - que é o que estas garantias visam a assegurar - é considerado por parte da doutrina econômica e contábil como um risco financeiro. O risco político, logo, seria da perda de reputação do país perante os seus investidores, bem como no câmbio de regulamentação de uma concessão pública. $\mathrm{O}$ artigo $8^{\circ}$ da Lei das PPPs, ao instituir estas garantias, veio para tentar mitigar estes riscos.
} 
contingenciamento, às limitações financeiras e atrasos nos pagamentos, diferentemente desses fundos ${ }^{411}$.

Os juristas reconhecem, no entanto, que há argumentos para se vetar o contingenciamento das receitas vinculadas. $\mathrm{O}$ artigo $9^{\circ}$, $\S 2^{\circ}$ da LRF dispõe: "não serão objeto de limitação as despesas que constituam obrigações constitucionais e legais do ente, inclusive aquelas destinadas ao pagamento do serviço da dívida, e as ressalvadas pela lei de diretrizes orçamentárias" (destacou-se). Como não se pode limitar a despesa ou obrigação constitucional ou legalmente estabelecida a um ente - o que, geralmente, possui íntima ligação às receitas vinculadas -, não haveria a possibilidade de seu contingenciamento $^{412}$. Porém, o próprio artigo $8^{\circ}$, parágrafo único, da $\mathrm{LRF}^{413}$ permite que os recursos vinculados sejam aplicados em exercício diverso daquele que ocorrer o ingresso, o que, pelo critério da especialidade, infirmaria a regra do artigo $9^{\circ}, \S 2^{\circ}$.

Importante característica - consoante mencionada ${ }^{414}$ - apontada pelos juristas é que a vinculação de receitas da Lei das PPPs deverá ser operacionalizada por lei específica, visto a obrigatoriedade de ser veiculada por esta espécie normativa. Diante disto, o dispositivo teria natureza meramente declaratória ${ }^{415}$.

Concordamos com este posicionamento, entretanto, com necessidade de algumas complementações. Em virtude da sistemática das vinculações de receitas e de sua vedação no Brasil, é impossível haver a vinculação de receitas de impostos por meio de normas infraconstitucionais, salvo nos casos ressalvados pelo artigo 167, IV, da Constituição Federal. Assim, restaria somente a possibilidade de vinculação de outras receitas que não a de impostos. Sob este prisma, não haveria razão jurídica para a existência do referido dispositivo, tendo em vista que a própria norma insculpida no artigo 167, IV, da Constituição Federal permite, a contrario sensu, a vinculação destas receitas ${ }^{416}$.

\footnotetext{
${ }^{411}$ Cf. RIBeIRO, Mauricio Portugal; Prado, Lucas Navarro. Comentários..., p. 206-09 e 226: "Portanto, a garantia de vinculação de receitas não elimina os sub-riscos políticos relacionados à ausência de satisfação do crédito do parceiro privado por ultrapassar os limites para empenho ou para pagamentos estabelecidos pelo decreto que dispõe sobre a programação financeira e estabelece o cronograma de execução mensal de desembolsos."

${ }^{412}$ Cf. RIBEIRO, Mauricio Portugal; PRADO, Lucas Navarro. Comentários..., p. 211. Os autores levantam a hipótese de que pode ocorrer a ausência de empenho em razão de decreto de contingenciamento, porém, salientam que há argumentos fortes que impedem o contingenciamento de receitas vinculadas, sem, no entanto, listarem quais são eles.

${ }^{413}$ Ver, com relação a este artigo, item 2.2.2 supra.

${ }^{414}$ Ver item 1.2 supra.

${ }^{415}$ Cf. RIBEIRO, Mauricio Portugal; PrADO, Lucas Navarro. Comentários..., p. 217-18. Entendem, todavia (nt. 12), que não haveria disposição constitucional que obrigasse a vinculação por lei, mas, em face da elaboração da lei orçamentária anual, ficaria comprometido o estabelecimento de vinculações por normas infralegais, pois, neste caso, a Lei Orçamentária Anual poderia "desvincular" a vinculação.

${ }^{416}$ Ver item 3.3.2 infra.
} 
Diante disto, o artigo $8^{\circ}$, I, mais do que meramente declaratório, é prescindível no ordenamento, visto que toda vinculação de receitas que não a de impostos ocorrerá por força de lei - em obediência ao caráter jurídico das vinculações ${ }^{417}$ - o que poderia ser feito sem a existência do referido comando na Lei das PPPs. Isto porque, conforme ventilado, qualquer vinculação por ato normativo que não seja legal ou constitucional é perfeitamente mutável por ato de mesmo grau do Poder Executivo, o que, na prática, não constituirá vinculação alguma. Isto porque ela poderá ser extinta a qualquer momento, não configurando, destarte, a concessão da segurança financeira que é o mote do estabelecimento de uma vinculação-garantia. Outra opção, ainda, seria a constituição de garantia por dotação orçamentária $a d h o c^{418}$, a ser definida em edital ou no contrato de concessão, mas tal técnica também não constituirá a vinculação de receitas como garantia.

Destacamos o sotoposto termo "jurídico" porque o desiderato perseguido pela norma das PPP é notadamente político: serve para tranquilizar os parceiros privados quanto à possibilidade de se haver a vinculação de receitas como garantia dos contratos públicos, além de deixar estreme de dúvidas, ao administrador público, a possibilidade de sua instituição. Como a vinculação de receitas possui a conotação de exceção, o gestor público estaria lastreado em um dispositivo legal ao vincular a receita a determinado contrato. Ademais, os parceiros privados também terão a certeza de que a sua garantia não poderá ser contestada judicial ou administrativamente se corretamente estabelecida, o que refletirá, fatalmente, em um custo menor na elaboração de sua proposta, aumentando a concorrência no certame licitatório e fomentando melhores contratações pelo poder público.

\subsubsection{CRÍTICA DOUTRINÁRIA AO DISPOSITIVO}

A utilização da vinculação de receitas como garantia dos contratos públicos é tida por parcela da doutrina como desaconselhável e vexatória à Administração, por ensejar

\footnotetext{
${ }^{417}$ Ver item 1.2 supra.

${ }^{418}$ A título de explanação, pode-se citar o exemplo da primeira PPP ocorrida no Brasil, a saber, na operação da rodovia MG-050. Esta concessão contou, em seu Edital de Abertura, com a seguinte previsão: "24.2. As despesas decorrentes da execução do contrato correrão à conta da dotação orçamentária 2301 Atividade26 782 208.1510, Fontes 10.1 e 51.1, Subprojeto 0001, Natureza 4.4.90.51, Item 07, do orçamento geral do DER/MG para o corrente exercício. Nos exercícios subseqüentes, durante a vigência do contrato, as despesas correrão à conta dos créditos próprios consignados à mesma dotação." Desta forma, demonstra-se que não há a vinculação de receita a órgão, e sim a uma específica dotação orçamentária de um órgão delimitado; e mais: se não existisse essa dotação, não haveria como efetivar o custeio das despesas. Similarmente ocorre, $v$. g., quando a Administração Pública celebra um contrato de compra de materiais, indicando a respectiva fonte de custeio dentro de seu próprio orçamento que subsidiará o cumprimento desta obrigação contratual.
} 
uma excussão do seu patrimônio, ferindo, destarte, o interesse público garantido constitucionalmente ao se instituir medidas menos drásticas para a satisfação do crédito do particular perante as Fazendas Públicas ${ }^{419}$.

KIYOSHI HARADA ${ }^{420}$ entende que o supracitado dispositivo, ao instituir a vinculação de receitas para garantir os credores, é inconstitucional, apesar da existência de observância quanto à restrição do artigo 167, IV da Constituição Federal. Para o autor, a ressalva é oriunda de uma interpretação equivocada ao se desconsiderar a regra da não vinculação das receitas públicas.

Entende o autor que as garantias possíveis de serem concedidas pelo poder público cingem-se, tão somente, às operações de crédito por antecipação de receita, segundo o artigo 167, IV, in fine, da Constituição da República. Outro ponto seria que a garantia dada infirma a regra da impenhorabilidade dos bens públicos, confundindo o conceito de garantia existente no direito público com a do direito privado, violando, com isto, a ordem estabelecida pelo regime de precatórios.

Outrossim, rechaça a hipótese de garantia a particulares, sob pena de afronta aos princípios da impessoalidade e da moralidade administrativa. Todo o tipo de receita pública em geral seria bem público indisponível, portanto, impassível de ser transformada em garantia. Argumenta também que a destinação do produto da arrecadação, neste caso, só poderia se dar via lei orçamentária, nos termos do artigo 165 , III e $\S \S 5^{\circ}, 6^{\circ}, 7^{\circ}$ e $8^{\circ}$ da Constituição Federal.

Em suma, o posicionamento de KIYOSHI HARADA ${ }^{421}$ é no sentido de que a regra geral é a da não vinculação de receitas públicas para a garantia de obrigações do poder público, sob pena de inversão e violação da ordem dos credores estabelecida pelo indigitado artigo constitucional.

Primeiramente, antes de se cogitar que determinada norma esteja conspurcada pela inconstitucionalidade, deve-se conceber o dispositivo legal em conformidade com o texto constitucional, in casu, o regime de execução da Fazenda Pública, de forma que eventuais inconstitucionalidades sejam levantadas com certa parcimônia. Desta forma, será exposta a interpretação que deve ser dada a este artigo a fim de salvaguardar a sua constitucionalidade.

\footnotetext{
${ }^{419}$ Cf. MeIRELles, Hely Lopes. Direito..., p. 543.

${ }^{420}$ Parceria público-privada - vinculação de receitas - instituição de fundos especiais - art. $8^{\circ}$, incs. I e II, da lei n. 11.079/04 - inconstitucionalidade (parecer). BDA: Boletim de Direito Administrativo. São Paulo. v.21. n.3. mar. 2005, p. 310-12. Cf., na mesma esteira, BANDEIRA DE Mello, Celso Antônio. Curso..., p. 774.

${ }^{421}$ Parceria..., p. 313.
} 


\subsubsection{INTERPRETAÇÃO PELA CONSTITUCIONALIDADE DO ARTIGO 8 , I, DA LEI DAS PPPs}

Para uma concepção do artigo $8^{\circ}$, I, da Lei n ${ }^{\circ}$ 11.079/04 conforme a Constituição, alguns conceitos merecem ser delineados. Por conta disto, intentaremos expô-los de forma a ensejar uma interpretação do referido dispositivo compatível com os demais dispositivos constitucionais.

Conforme já trazido à discussão, há a nítida diferença entre a vinculação da receita de impostos, vedada constitucionalmente, e a vinculação de outras receitas, onde o tratamento constitucional dado à matéria é mais brando. Não pode haver degenerescência entre esta distinção de suma importância. A regra da não vinculação atinge tão somente os impostos em qualquer tipo de norma sobre o tema, inclusive no caso da Lei $\mathrm{n}^{\circ}$ 11.079/04. Por exemplo, já apontou José Augusto Moreira DE CARvalho ${ }^{422}$ que não há impedimento para uma sociedade de economia mista ${ }^{423}$ vincular suas receitas futuras (preços públicos) de forma a garantir suas obrigações contraídas, conforme ocorreu no contrato de PPP da sociedade de economia mista estadual Empresa Baiana de Águas e Saneamento (EMBASA).

Mauricio Portugal Ribeiro e Lucas NAVARro Prado ${ }^{424}$, na mesma esteira, entendem que a vinculação de receitas de empresas estatais não está contida no comando do artigo 167, IV, da Constituição Federal. Ademais, destacam outras receitas, como os valores pagos a título de outorga pelas concessões de serviço público, receitas de arrendamento de infraestrutura ou royalties, como ocorre nas PPPs no setor ferroviário. Expressam também que, exceto os tributos que já possuam destinação legal - como taxas, v. $g .-$, todas as outras receitas poderiam ser utilizadas como garantia.

Quanto a este último aspecto, REGIS FERNANDES DE OLIVEIRA ${ }^{425}$, diferentemente, entende que não haveria impedimento para que as taxas fossem oferecidas como garantia nas PPPs. Além do mais, toda sorte de recurso não tributário poderia ser vinculado, como as receitas oriundas de exploração petrolífera ou mineral.

\footnotetext{
${ }^{422}$ As Parcerias..., p. 158.

${ }^{423}$ Cf. SundFeld, Carlos Ari. Guia Jurídico das Parcerias Público-Privadas. In: SundFeld, Carlos Ari (coord.). Parcerias..., p. 41. As empresas estatais podem ser concedentes de PPPs, consoante permite o próprio artigo $1^{\circ}$ da Lei $\mathrm{n}^{\mathrm{o}} 11.079 / 04$.

${ }^{424}$ Comentários..., p. 218 , nt. 13 e p. 219-20.

${ }^{425}$ Curso..., p. 508.
} 
Com relação a esta pequena divergência, somos compelidos a adotar a opinião deste financista, visto que o artigo 167, IV, taxativamente exclui somente os impostos. A distinção doutrinária entre tributos vinculados e não vinculados, no nosso entender, é irrelevante para a caracterização da vinculação de sua receita. Adicionaríamos que, em havendo uma relação mínima de pertinência entre a exação tributária e a atividade estatal prestada para não desconfigurar a taxa como imposto (conforme dita o artigo 77 do CTN), nada impediria esta prática $^{426}$. Em uma concessão, v. g., eventuais taxas pagas para a participação no certame licitatório poderiam ser vinculadas como garantia ao cumprimento do respectivo contrato, possibilitando a sua vinculação como garantia ${ }^{427}$. Ou então as taxas cobradas pelo poder público que tenham relação com a atividade poderiam ser usadas com este escopo, como em uma PPP para administração penitenciária.

Também merece ser debatida a concepção estrita de possibilidade de vinculação: cogitar-se-ia que é vedada a vinculação de receitas a garantias tendo em vista que o texto constitucional só a permite, nesta função, para os créditos por antecipação de receita orçamentária - ARO; logo, quaisquer outras garantias seriam indevidas ${ }^{428}$. Entendemos que o conceito de garantia não pode ser deturpado por uma interpretação gramatical tergiversada do artigo, que não se limita a coarctar os tipos de garantias possíveis a serem dadas pelo poder público em suas contratações, mas tão somente trata das operações de crédito por antecipação de receita orçamentária. O dispositivo constitucional prescreve apenas que pode haver a vinculação-garantia com receita de imposto para as AROs: quanto às demais, não sendo vinculação com receita de imposto, qualquer tipo de receita poderá ser prestada como garantia, pois o caput permite a vinculação a contrario sensu da proibição com relação aos impostos, não importando as funções destas afetações.

Outrossim, não há, no indigitado dispositivo, açoite ao regime de precatórios, pois este pressupõe a existência de crédito controvertido em face da Fazenda Pública: há o direito de crédito pelo particular contra a Administração que não é prontamente reconhecido por ela, de forma que se faz mister a existência de uma sentença judicial transitada em julgado para que haja a obrigação de pagamento ao credor ${ }^{429}$.

\footnotetext{
${ }^{426}$ Cf. SCAFF, Fernando Facury. Para além..., p. 1142. Segundo o autor, “(...) a vinculação diz respeito à correlação entre causa e efeito; entre as razões que justificam a exigência daquele tributo e a contraprestação estatal decorrente de sua arrecadação."

${ }^{427}$ Tal exemplo é dado apenas para fins didáticos, visto que o montante envolvido nestas operações tributárias não influiria substancialmente a fim de garantir a boa observância do contrato de concessão. Ver outro exemplo de vinculação das receitas de taxas no item 4.1.3.1 infra.

${ }^{428}$ Cf. Harada, Kiyoshi. Parceria..., p. 310 e ss.

${ }^{429}$ Cf. OliveIRA, Regis Fernandes de. Curso..., p. 534: "Precatório ou ofício precatório é a solicitação que o juiz da execução faz ao presidente do tribunal respectivo para que este requisite verba necessária ao
} 
Já no caso de execução dos contratos, não há o inadimplemento contratual. Pelo contrário: há o interesse da Administração em cumprir com as suas obrigações contratuais, primeiro mediante o uso das receitas afetadas e, caso seja insuficiente, via outras dotações orçamentárias $^{430}$. Por evidente que, em respeito ao pacta sunt servanda ${ }^{431}$, na hipótese de os referidos recursos serem insatisfatórios, a Administração Pública deverá valer-se de outros meios orçamentários para satisfazer o crédito de seu credor, sem que isto implique violação ao regime de precatórios incrustado no artigo 100 da Constituição Federal.

E não há nada de inconstitucional nisto. Se assim o fosse, a Administração Pública nunca poderia contratar com particulares, pois o mero adimplemento contratual feriria o regime dos precatórios, afinal, esse ato acarretaria a preterição da ordem de pagamento dos créditos. Se não houvesse a diferenciação entre os créditos oriundos de sentença judicial e os de contratos administrativos ainda não executados, não haveria o porquê de existir o regime de precatórios, de forma que todo crédito em face da Administração deveria seguir a ordem de cumprimento determinada. Isto seria irracional do ponto de vista contratual, uma vez que fatalmente não haveria um indivíduo que se sujeitasse a tal hipótese, já que não existirá uma certeza de pronto pagamento pelo poder público, mas sim uma mera probabilidade, devendo o credor aguardar o seu crédito, controvertido ou não, em uma "fila" até o seu recebimento.

$\mathrm{O}$ que a vinculação de receitas faz, conforme já mencionado ${ }^{432}$, é garantir que este determinado montante não seja utilizado para outros fins a não ser para o pagamento da contraprestação contratual - segundo estabelecido por lei específica - ao parceiro privado nas PPPs $^{433}$. Porém, haveria sentido - e possibilidade - em o poder público recusar-se ao adimplemento contratual mesmo havendo recursos disponíveis para tanto?

Mauricio Portugal Ribeiro e LuCAs NAVARro Prado ${ }^{434}$, em resposta à indagação, afastam a aparente contradição do argumento por meio da exposição de duas razões para esta denegação de pagamento: a primeira é para haver o controle da qualidade do gasto público: caso o contrato não produza os efeitos conforme previsto, por demonstrar

pagamento de credor de pessoa jurídica de direito público, em face de decisão judicial transitada em julgado." (destacou-se)

${ }^{430}$ Cf. RibeIRO, Mauricio Portugal; PRADO, Lucas Navarro. Comentários..., p. 226. Desta forma, os autores entendem que o risco político assumiria, neste caso, “(...) um perfil de risco econômico de realização da receita."

${ }^{431}$ Cf. OliveIRA, Regis Fernandes de. Curso..., p. 600. Conforme expõe o autor, com a vontade manifestada de forma livre e sem amarras, há a "obrigatoriedade da convenção" - ou o chamado pacta sunt servanda.

${ }^{432}$ Ver item 2.3.1 supra.

${ }^{433}$ Cf. RIBEIRO, Mauricio Portugal; PrAdo, Lucas Navarro. Comentários..., p. 221.

${ }^{434}$ Comentários..., p. 224. 
projetos mal-elaborados ou inexequíveis, o administrador teria o dever de recusar o pagamento em prol do interesse público. A outra razão seria a constante política governamental de superávit primário que ensejaria alguns contingenciamentos.

Portanto, tal dispositivo serviria, na visão dos autores, sobretudo para reforçar que os créditos vinculados ao pagamento das obrigações contratuais sejam inscritos na lei orçamentária, já que até mesmo a revogação da vinculação não prejudicaria o particular, pois ensejaria o reequilíbrio da equação econômico-financeira do contrato. Isto decorre porque esta equação é intangível nos dizeres de CELSO ANTÔNIO BANDEIRA De MELlo ${ }^{435}$, em homenagem à própria relação de igualdade obrigacional estabelecida entre as partes obrigação e pagamento.

Desta forma, como a garantia é considerada no preço proposto pelo particular em um certame, a sua revogação irá refletir-se nesta equação de alguma forma (os juros sobre o capital tomado pelo empréstimo podem se alterar, por exemplo), devendo ensejar, destarte, o reequilíbrio contratual. Logo, a única possibilidade ao poder público em não ordenar a despesa é no caso de serviço não adequadamente prestado, em nome do interesse público que rege esta relação contratual ${ }^{436}$, cujo dever lhe impõe o controle da qualidade do gasto público. Cumpre lembrar, por fim, que as receitas vinculadas só poderão ser utilizadas para o escopo específico de sua ligação - conforme já $\operatorname{tratado}^{437}$-, que é justamente o adimplemento da obrigação contraída.

\subsubsection{A VINCULAÇÃO-GARANTIA INTERFEDERATIVA}

\subsubsection{REPASSE DE RECURSOS E RECEITAS PARTILHADAS E TRANSFERIDAS}

JOSÉ MAURICIO CONTI ${ }^{438}$ explica que, normalmente, quando a legislação destina determinados recursos para os entes federativos, pode estabelecer transferências automáticas e obrigatórias ou então voluntárias. No primeiro caso, podem-se extrair como exemplos os Fundos de Participação dos Estados e Municípios, donde se colige que a

\footnotetext{
${ }^{435}$ Curso..., p. 630-31.

${ }^{436}$ Cf. RIBEIRO, Mauricio Portugal; PRADO, Lucas Navarro. Comentários..., p. 225.

${ }^{437}$ Ver itens 1.2 e 2.2.2 supra.

${ }^{438}$ Federalismo..., p. 76.
} 
distribuição de recursos deve ser automática, incondicionada e obrigatória, nos ditames legais previamente estabelecidos.

Questão relevante é com relação à vinculação de verbas dos impostos próprios e dos recursos transferidos ou partilhados, visto parcela da doutrina entender que há diferenciação entre estes conceitos. Primeiramente, é necessário verificar a diferença entre repartição e partilha de receitas e distribuição de competências.

JOSÉ AFONSO DA SILVA ${ }^{439}$ divide as rendas dos entes subnacionais como oriundas da partilha da competência por espécie tributária - podendo se dar por distribuição por adicionais ou mediante atribuição concorrente - ou da distribuição de receitas tributárias por intermédio de subvenções, por exemplo ${ }^{440}$. ANTÔNIO ROBERTO SAMPAIO DÓRIA ${ }^{441}$, nesta esteira, subdivide o conceito de discriminação de rendas em discriminação pela fonte (tributos, forma original de discriminação) e discriminação pelo produto (forma derivada e indireta de participação nas receitas que não lhes são próprias).

JEAN ANASTOPOUPLOS ${ }^{442}$ expõe os prós e contras da repartição ou partilha das receitas e distribuição das competências por detrás desta engrenagem, além da vontade em haver a uniformidade fiscal almejada, por exemplo, pelos Estados unitários. O interesse em se evitar o excesso de gasto público, a possibilidade de políticas de equalização vertical e horizontal e o financiamento uniforme de serviços públicos são citados como alguns benefícios deste tipo de repartição. Porém, há um evidente atentado à autonomia dos entes subnacionais, que ficariam subordinados às políticas centrais.

Feito este apanhado inicial, convém destacar que não há como se conjecturar se a transferência de recursos mudaria, ou não, a natureza da receita, ou seja, se antes de transferida ela seria uma receita federal, estadual ou municipal. A mera vinculação desta receita oriunda de impostos esbarraria nos limites constitucionais existentes, sem necessitar de uma detenção mais elevada quanto à análise da natureza jurídica destas transferências.

Ademais, tamanha é a imperatividade deste preceito que já foi declarada a inconstitucionalidade de um parágrafo da Constituição do Estado de Rondônia que

\footnotetext{
${ }^{439}$ Tributos..., p. 14-15.

${ }^{440}$ Cf. também REZENDE DA SILVA, Fernando Antonio. Brasil..., p. 111. Para o autor, "partilhar competências é diferente de partilhar as receitas dos tributos. Na partilha de receitas, o tributo pertence a uma das partes, quase sempre o governo central (...)". Desta forma, caberia ao ente central realizar a repartição do produto da arrecadação. Já "na partilha de competências, o tributo pertence a ambos, União e estados, que negociam conjuntamente, no Congresso, a legislação aplicável e as alíquotas que correspondem à parcela de cada um no tributo em questão."

${ }^{441}$ Discriminação de rendas tributárias. São Paulo: J. Bushatsky, 1972, p. 18-22.

${ }^{442}$ Les aspects financiers du fédéralisme. Paris: L G D J, 1979, p. 169.
} 
determinava despesa obrigatória com a receita das transferências a ações de saúde, incluindo a receita proveniente de impostos ${ }^{443}$.

O dispositivo, excluído in totum do ordenamento jurídico, prescrevia:

Art. 241 - O Sistema Estadual de Saúde será financiado com recursos do orçamento do Estado, da seguridade social da União e dos Municípios, além de outras fontes.

$\S 1^{\circ}$ - O Estado aplicará, anualmente, nunca menos de dez por cento da receita resultante de impostos, compreendida a proveniente de transferências. (destacou-se)

A Corte entendeu ser perceptível a "vinculação" de receitas de impostos, vedada na Constituição, sendo estas as razões expostas no voto do Relator e na respectiva ementa. A despeito de não constituir tecnicamente uma afetação (mas sim uma despesa obrigatória), infere-se que o acórdão considerou que a receita proveniente de transferências mantém a sua natureza em relação à origem da arrecadação - no caso, a de impostos.

Politicamente, entendemos que não é de boa recomendação a destinação (ou vinculação) da receita transferida dirigida a este fundo. É que as vicissitudes políticas podem fazer com que surjam medidas legislativas como esta apenas para "agradar" o ente mais poderoso (no caso, a União), em prejuízo do próprio ente que a institui, as quais continuarão subsistindo no ordenamento. Diante disto, a receita proveniente das transferências constitucionais deve permanecer incólume a quaisquer concertos políticos.

KIYOSHI HARADA ${ }^{444}$, assim, explica que a Constituição Federal "não distingue os impostos próprios das verbas a que fazem jus Estados e Municípios por participação de fundos formados por produtos de arrecadação do IPI e do imposto sobre a renda (art. 159, I e II) da CF".

Desta forma, não se sustentaria o argumento de que as receitas vindas de transferências do produto da arrecadação dos impostos por outros entes federativos não esbarrariam no óbice constitucional do princípio da não afetação da receita de impostos. $\mathrm{O}$ autor justifica sua posição, inclusive, com a permissão legal dada pelo artigo $167, \S 4^{\circ}$ da Constituição Federal, donde se excepciona a regra geral ao facultar a vinculação de receitas próprias e alheias à competência impositiva do respectivo ente (artigo 159, CF) na prestação de garantias à União ${ }^{445}$.

\footnotetext{
${ }^{443}$ ADI 1.848-3/RO. Rel. Min. Ilmar Galvão. j. 5 set. 2002. DJU 25 out. 2002.

${ }^{444}$ Vinculação pelo Município das cotas do ICMS para garantia de operações de crédito: efeitos. Repertório de Jurisprudência: tributário, constitucional e administrativo. São Paulo. n. 2. jan. 1999, p. 95.

${ }^{445}$ Cf. HaradA, Kiyoshi. Vinculação..., p. 96. Por um lapso, o autor, em seu trabalho, menciona o artigo 165 da Constituição Federal. Porém, o correto é o artigo 167, § $4^{\circ}$.
} 
Concordamos plenamente com a opinião do jurista. Ousamos, todavia, abrir um parêntese para discordar apenas quanto ao aspecto formal da diferenciação que elabora entre os recursos provenientes dos fundos de participação e os recursos oriundos das partilhas de receitas de impostos (como IPVA ou o ITR). O autor entende que, no primeiro caso, os fundos de participação concederiam aos demais entes (Estados ou Municípios) a mera expectativa de receber a sua respectiva parte. Já no segundo caso, há uma relação de pertinência da receita com o ente beneficiado, tendo em vista que o texto constitucional já garante um percentual fixo de participação ("Pertencem aos Estados/Distrito Federal/Municípios") ${ }^{446}$.

Não entendemos desta forma, uma vez que não há esta diferenciação prática na Carta Magna: as receitas já são de titularidade do ente beneficiado, quer transferidas ou partilhadas. Caso assim não fosse, a União poderia deixar de entregar os recursos encartados no artigo 159 a fim de comporem os Fundos de Participação dos Estados e dos Municípios. E não há essa permissão: o artigo 159 é cristalino e mandatório neste sentido (“A União entregará”).

Não é, portanto, necessária a diferenciação feita pelo autor quanto à expressão do artigo 159 em cotejo com as dos artigos 157 e 168 ("Pertencem aos Estados e ao Distrito Federal" e "Pertencem aos Municípios"), por, efetivamente, inexistir qualquer implicação prática entre "entregar" e "pertencer" no texto constitucional ${ }^{447}$. E não há mera expectativa de receber estes recursos, uma vez que já são de titularidade do ente beneficiário. As transferências (mera operação) concretizariam apenas o pleno usufruto destes recursos.

O Supremo Tribunal Federal, porém, contrário a este posicionamento, entende que a vedação constitucional do artigo 167, IV restringe-se apenas aos tributos próprios, permitindo, portanto, utilização da parcela de ICMS destinada ao repasse municipal para satisfazer dívidas de determinado Município ${ }^{448}$. Apesar de não abordado nestas decisões, merece ser destacado que a questão primordial é que a vinculação só poderá ocorrer para

\footnotetext{
${ }^{446}$ Cf. HARADA, Kiyoshi. Vinculação..., p. 95.

447 Cf. HARADA, Kiyoshi. Vinculação..., p. 95. O autor apregoa a existência de três modalidades de participação dos Estados, DF e Municípios nas receitas tributárias da União e Estados. Uma é a participação direta destes entes no produto da arrecadação do IR incidente na fonte pago por suas fundações e autarquias. A segunda é a receita partilhada nos artigos 157 e 158 da CF. A última é a participação nos fundos federativos, com a mera expectativa de receber. A classificação é salutar para fins didáticos, porém, daí não se pode extrair nenhuma diferenciação que possa se concluir pela "mera expectativa de receber", pelos motivos já expostos e afirmados.

${ }^{448}$ Recurso Extraordinário no ${ }^{184.116-8 / M S . ~} 2^{\text {a }}$ Turma. Rel. Min. Marco Aurélio. j. 7 nov. 2000. DJU 16 fev. 2001: “(...) ACORDO - DÉBITO - ICMS - PARTICIPAÇÃO DO MUNICÍPIO. Inexiste ofensa ao inciso IV do artigo 167 da Constituição Federal, no que utilizado o produto da participação do município no ICMS para liquidação de débito. A vinculação vedada pelo Texto Constitucional está ligada a tributos próprios."
} 
avalizar negociações com a União, conforme destacadamente aparece no texto constitucional no $\S 4^{\circ}$ do artigo 167. Desta forma, entendemos que, por se tratar de vinculação de receitas na forma de garantia a contratos celebrados entre Estado e Município, tal instrumento já estaria contaminado pela inconstitucionalidade por não ser possível a extensão de tal regra em favor dos Estados. A interpretação, destarte, deve ser restritiva.

\subsubsection{A RETENÇÃO DA UNIÃO FEDERAL AO REPASSE DE RECURSOS (ART. 167, $4^{\circ}$, in fine, CF e ART. 40, $§ 1^{\circ}$, II, LRF)}

Na Itália, LUIGI EINAUDI ${ }^{449}$ relata o antigo hábito nacional de utilização das delegações, que obrigavam os arrecadadores municipais à realização da entrega de forma direta dos recursos delegados ao credor, sem que passassem pelo caixa da Fazenda Municipal. Com isto, havia a possibilidade de o ente central obrigar as municipalidades relutantes em adimplir seus débitos perante os credores.

Já na Argentina, HoRACIO GUILLERMO $\operatorname{CORTI}^{450}$ explica que, no tocante às repartições para o federalismo fiscal, há uma regra geral em que os recursos federais são dispostos em uma massa única e parcela deste montante é distribuída às províncias nos termos do regime de coparticipação tributária definido normativamente, enquanto que a quantia restante que adentra é especificada de acordo com a lei orçamentária. Porém, como também há exceções às regras gerais, observa-se a existência de diversas afetações específicas sobre o montante adstrito às coparticipações legais, utilizando-se do ardil de subtrair estas quantias da massa única estatal.

Aqui, inspirado nessa modalidade de controle, o artigo 167, § $4^{\circ}$, in fine, da Carta Magna prevê a possibilidade de prestação de vinculação de receitas como garantia à União, inclusive no tocante ao pagamento de débitos de outros entes para com esta. Para tanto, é permitida a afetação da receita dos impostos estaduais e municipais, além dos recursos oriundos das partilhas e transferências aos Fundos de Participação dos Estados e

\footnotetext{
${ }^{449}$ Principios..., p. 377.

${ }^{450}$ Derecho constitucional..., p. 128 e ss. e 312. O autor menciona excelente ensaio elaborado por ENRIQUE BULIT GOÑI sobre a coparticipação argentina, a qual se inseriu no sistema constitucional na reforma de 1994. O regime de coparticipação, no entanto, é visto por alguns doutrinadores com certa parcimônia. LUCA ANTONINI (Dal federalismo legislativo al federalismo fiscale. Rivista di Diritto Finanziario e Scienza delle Finanze. Milano. v. 63. n. 3. sett. 2004, p. 421) entende que, neste tipo de sistema, a popularidade da despesa fica com o ente que recebe os recursos, enquanto que a impopularidade da imposição fica com o ente arrecadador.
} 
Municípios, excetuando a parcela destinada aos programas de financiamento do setor produtivo das Regiões Norte, Nordeste e Centro-Oeste e a da CIDE-Combustíveis não afetada. Constitui-se, destarte, em uma vinculação-garantia interfederativa.

FRANCISCO ALVES DOS SANTOS JÚNIOR ${ }^{451}$ menciona que esta ressalva tira, praticamente, toda a eficácia do princípio da não afetação, ao permitir a vinculação dos impostos estaduais e municipais e inclusive das verbas recebidas a título de transferência, demonstrando que a Constituição Federal pecou pelas inúmeras exceções ao princípio ao tratar das dívidas para com a União dos demais entes federativos.

O artigo 40, $\S 1^{\circ}$, II da Lei de Responsabilidade Fiscal, ao disciplinar esta regra constitucional, previu a possibilidade de oneração e execução direta destas verbas públicas ao admitir o seu emprego no pagamento da respectiva dívida, em colisão ao artigo 100 da Constituição Federal $^{452}$. A doutrina nunca entendeu ser possível este tipo de vinculação, conforme expõe REGIS FERNANDES DE OLIVEIRA ${ }^{453}$. Com o advento do parágrafo quarto no artigo 167 pela Emenda Constitucional n ${ }^{\circ}$ 3, de 1993, conclui o autor que, deveras, não havia esta possibilidade antes da introdução da norma constitucional.

MisABel De ABReu MACHAdo DeRzI ${ }^{454}$ ensina que a vinculação de receitas não pode se confundir com a expropriação de receita, já que a vinculação como garantia é comando destinado ao legislador orçamentário, dada a irrenunciabilidade das receitas públicas. Na opinião de CARLOS MAURício FigUEIREDo et $\mathrm{al}^{455}$, o uso das transferências como garantia serviria para conceder liquidez e certeza ao crédito. Ressaltam, entretanto, que "o condicionamento das transferências constitucionais (...) não deve ser promovido, a não ser que os recursos dessas transferências constitucionais tenham sido voluntariamente oferecidos como contragarantia, na forma disposta no artigo 40, II, da LRF."

KIYOSHI HARADA ${ }^{456}$, nesta esteira, explica que tal garantia não pode ser considerada como garantia real do direito civil (pignoratícia, hipotecária, etc.), a despeito de mencionar a existência de posição contrária a esta concepção. Ademais, perfilha o autor o entendimento de que o ente federativo teria mera expectativa de recebimento das

\footnotetext{
${ }^{451}$ Curso..., p. 52.

452 Cf. HARADA, Kiyoshi. Responsabilidade Fiscal: lei complementar n. 101/2000 comentada e legislação correlata anotada. São Paulo: Juarez de Oliveira, 2002, p. 180 e 182.

${ }^{453}$ Responsabilidade fiscal. 2. ed. São Paulo: RT, 2002, p. 85-86. O jurista explica que doutrinadores como FrANCISCO CAMPOS e CELSO ANTONIO BANDEIRA DE MELlo rechaçavam a utilização da vinculação de receitas como garantia antes mesmo do surgimento do indigitado dispositivo

${ }^{454}$ Arts. 40..., p. 293-95.

${ }^{455}$ Comentários à Lei de Responsabilidade Fiscal. 2. ed. São Paulo: RT, 2001, p. 223-24.

456 Operações de crédito e vinculação de receitas tributárias. Disponível em: $<$ http://www.fiscosoft.com.br/main_index.php?home=home_artigos\&m=_\&nx_=\&viewid=98536>. Acesso em: 16 out. 2008.
} 
transferências intergovernamentais dos tributos que não são de sua esfera impositiva, o que já foi rechaçado algures ${ }^{457}$.

Outro argumento levantado que contesta esta modalidade introduzida é no tocante à mitigação da capacidade de transação ou negociação do ente devedor. No Agravo Regimental no Recurso Extraordinário no 234.495-6/MT ${ }^{458}$, o Supremo Tribunal Federal registrou, com fulcro no parecer do Procurador-Geral da República, que o nó górdio do problema da vinculação de receitas para garantia de créditos é que se mutilaria a capacidade de transigir e negociar dos municípios, tendo em vista que a apropriação - in casu, pelo Banco Santos - dos recursos necessários ao adimplemento da dívida seria imediata. Desta forma, a própria gerência das receitas municipais ficaria comprometida.

É neste sentido que a jurisprudência iterativa do Tribunal de Justiça gaúcho também entende com relação à inconstitucionalidade destas cláusulas, ao reconhecer a invalidade de uma disposição que vinculava quota de participação dos Municípios referente à receita do ICMS - no que tange aos contratos de fornecimento de energia elétrica pela Companhia Estadual de Energia Elétrica. Mediante um termo de confissão de dívida, permitia-se o desconto dos valores em conta destinada ao crédito dos repasses de ICMS ao Município ${ }^{459}$.

Defende acertadamente, portanto, JosÉ MAURICIO CONTI ${ }^{460}$ que, caso não haja a interpretação sistemática da Constituição, há o risco de diminuição da autonomia $^{461}$ das demais unidades federadas. Segundo o financista, a autonomia financeira destes entes é assegurada, em grande parcela, em virtude das transferências intergovernamentais, de forma que qualquer tentativa de apossamento destes recursos por outro ente significaria o seu tolhimento. Dessarte, o conceito de vinculação deve ser interpretado restritivamente, sob pena de afronta à cláusula inabolível do pacto federativo, não podendo haver restrições à entrega destas verbas. REGIS FERNANDES DE OLIVEIRA ${ }^{462}$ leciona, neste sentido, que “(...) condicionar não significa reter. É criar condições, apenas.” Estas considerações delimitam,

\footnotetext{
${ }^{457}$ Ver item 2.3.5.1 supra.

${ }^{458}$ Pleno. $2^{\text {a }}$ Turma. Rel. Min. Carlos Velloso. j. 17 mai. 2005, DJU 17 jun. 2005, p. 367.

${ }^{459}$ Agravo de Instrumento 70006502058. $2^{\mathrm{a}}$ Câmara Cível. Rel. Des. José Luiz John Dos Santos. j. 31 mar. 2004. DJE 31 mar. 2004 e Agravo de Instrumento 70004172714. 2a Câmara Cível. Rel. Des. Arno Werlang. j. 16 out. 2002. DJE 16 out. 2002.

${ }^{460}$ Federalismo..., p. $122-24$ e 147

${ }^{461}$ No entender de JOSÉ JOAQUIM TEIXEIRA RIBEIRO (Lições..., p. 69), a autonomia financeira pressupõe a existência de receitas e orçamentos próprios. Adicionamos que a capacidade de autogestão também vem nesse sentido.

${ }^{462}$ Curso..., p. 466
} 
outrossim, a interpretação a ser feita com relação ao artigo 160, parágrafo único, da Constituição Federal.

Em suma, a União Federal não pode manter estas receitas em seu orçamento, sob pena de infringência ao dispositivo constitucional, afinal, deixar de entregar corresponde a deter para si próprio, tertium non datur. E o texto constitucional não previu a repartição de receitas destes impostos de forma inútil, em homenagem a mais um aforismo hermenêutico: verba cum effectu, sunt accipienda ${ }^{463}$.

Neste caso, os entes devedores deverão fazer constar em suas respectivas leis orçamentárias esta destinação específica para o pagamento das obrigações contraídas. Não há que se cogitar, portanto, em apropriação à primeira vista pela União dos recursos mencionados. E os entes federados terão que, naturalmente, inscrever tal destinação na lei orçamentária, uma vez que na feitura do plano plurianual e da lei de diretrizes orçamentárias já há a respectiva previsão de despesas atinentes ao contrato cujas obrigações impõem a referida despesa ${ }^{464}$.

Resta estreme, portanto, a inconstitucionalidade do artigo $40, \S 1^{\circ}$, II da Lei de Responsabilidade Fiscal - conforme destacado por JOSÉ MAURICIO CONTI ${ }^{465}$ - ao conceder poder de retenção à União das receitas mediante concessão de outorga de poderes pelo ente devedor. Não se coaduna o indigitado preceito com uma interpretação conforme a Constituição.

Como exemplo de impossibilidade de retenção destas verbas, é próspero aplaudir o artigo 271 da Constituição do Equador, cuja fixação, no sentido de que as transferências das receitas aos entes federativos serão diretas e automáticas, sepultou qualquer ideia que se venha a ter com relação à retenção por parte do ente repassador. Ei-lo:

Los gobiernos autónomos descentralizados participarán de al menos el quince por ciento de ingresos permanentes y de un monto no inferior al cinco por ciento de los no permanentes correspondientes al Estado central, excepto los de endeudamiento público. Las asignaciones anuales serán predecibles, directas, oportunas y automáticas, y se harán efectivas mediante las transferencias desde la Cuenta Única del Tesoro Nacional a las cuentas de los gobiernos autónomos descentralizados. (destacou-se)

\footnotetext{
${ }^{463}$ Cf. Maximiliano, Carlos. Hermenêutica e Aplicação do Direito, Rio de Janeiro, Forense, 2000, p. 250, pois "as expressões do Direito interpretam-se de modo que não resultem frases sem significação real, vocábulos supérfluos, ociosos, inúteis".

464 Cf. ConTI, José Mauricio. Federalismo..., p. 124. Nesta esteira, Cf. HARAdA, Kiyoshi. Responsabilidade..., p. 186: "O que não pode, em nosso entender, é emprestar a essa vinculação o sentido de garantia real, permitindo ao credor a apropriação direta da receita pública, cujo ingresso aos cofres públicos decorre de imperativo constitucional e legal. A quitação da obrigação de dar, a cargo do poder público, só pode ocorrer mediante pagamento da despesa legalmente autorizada, ou seja, por meio da dotação respectiva prevista na lei orçamentária anual."

${ }^{465}$ Federalismo..., p. 124.
} 
Por conseguinte, para salvaguardar o referido dispositivo, dever-se-á expurgar do ordenamento jurídico a expressão "com outorga de poderes ao garantidor para retê-las e empregar o respectivo valor na liquidação da dívida vencida"466 . Diante disso, o Supremo Tribunal Federal, em sede de julgamento de uma Ação Direta de Inconstitucionalidade, poderá, mediante o princípio da parcelaridade, excluir este trecho do ordenamento jurídico, declarando inconstitucional o artigo no que toca a esta parcela de seu conteúdo.

Face às inúmeras controvérsias nos tribunais, o Supremo Tribunal Federal procurou pacificar a questão mediante a edição da Súmula Vinculante no 30: "É inconstitucional lei estadual que, a título de incentivo fiscal, retém parcela do ICMS pertencente aos municípios". A Súmula teve, no entanto, sua publicação suspensa pelo Plenário do Sodalício do dia 5 de fevereiro de 2010, após questão de ordem levantada pelo Ministro José Antonio Dias Toffoli.

\subsubsection{A VINCULAÇÃO-GARANTIA DE RECEITAS TRANSFERIDAS: O CASO DA LEI BAIANA No 11.477/2009}

A necessidade de se utilizar as receitas públicas para garantia, conforme demonstrado, não pode levar à vinculação da receita de impostos, sob pena de inconstitucionalidade flagrante. Ocorre que o Estado da Bahia sancionou, em $1^{\circ}$ de julho de 2009, a Lei $n^{\circ} 11.477$, que trata da vinculação da quota-parte que lhe cabe no Fundo de Participação dos Estados para um órgão específico. Eis o artigo $1^{\circ}$ que proscreve esta permissão de vinculação de impostos a órgão:

Art. $1^{\circ}$ - Para fins de adimplemento das obrigações contraídas pelo Estado da Bahia e
por entidades da sua administração indireta em contratos de parceria público-privada,
nos termos do art. 16, inciso II, da Lei Estadual $n^{\circ} 9.290$, de 27 de dezembro de 2004 ,
fica o agente financeiro responsável pelo repasse dos recursos do Fundo de Participação
dos Estados e do Distrito Federal (FPE) autorizado a efetuar a transferência do valor
correspondente a $12 \%$ (doze por cento) dos recursos financeiros oriundos desse Fundo,
destinados ao Estado da Bahia, à DESENBAHIA - Agência de Fomento do Estado da
Bahia S.A., pessoa jurídica de direito privado, constituída como sociedade anônima de
capital fechado, conforme autorização da Lei Estadual no 2.321 , de 11 de abril de 1966 .

Parágrafo único - A DESENBAHIA - Agência de Fomento do Estado da Bahia S.A. deverá manter os recursos que lhe sejam transferidos na forma do caput deste artigo segregados dos demais recursos de sua titularidade, em conta corrente específica a ser aberta no agente financeiro responsável pelo repasse dos recursos do FPE, destinando-

${ }^{466}$ Cf. Assoni FILHo, Sérgio. Crédito público e responsabilidade fiscal. Porto Alegre: Nuria Fabris, 2007, p. 144-45. O que a Constituição Federal autoriza é o condicionamento destas receitas com a sua respectiva retenção, não permitindo a quitação automática da dívida. Cf. neste sentido DERZI, Misabel de Abreu Machado. Arts. 40..., p. 287 e 299. 
os, exclusivamente, ao adimplemento das obrigações contraídas pelo Estado da Bahia e suas entidades da administração indireta em contratos de parceria público-privada, sob pena de responsabilização dos seus administradores, nos termos da lei, podendo a DESENBAHIA - Agência de Fomento do Estado da Bahia S.A. autorizar o agente financeiro a transferir os recursos diretamente à conta do concessionário, conforme disposto nos contratos de parceria público-privada. (destacou-se)

É necessário analisar, portanto, se há a possibilidade de se vincular a receita da quota-parte que cabe a um Estado do Fundo de Participação dos Estados para garantia do crédito, valendo tal análise também para outros casos. Sob o nosso entender, há duas interpretações possíveis.

A primeira é que tal possibilidade é viável por conta da interpretação do artigo 167, IV, da Constituição Federal, que será analisado posteriormente ${ }^{467}$. Se o artigo exclui expressamente da regra proibitória a repartição das receitas dos impostos para o federalismo fiscal (artigos 158 e 159), não haveria como se proibir a vinculação $a$ posteriori destas receitas, ou seja, após a respectiva transferência operacionalizada pelo Fundo de Participação. Desta forma, entrariam como receitas livres de qualquer restrição de não vinculação.

Questão que merece ser trazida à baila com relação ao tema foi levantada de forma paradigmática pela Lei paulista $\mathrm{n}^{\circ} 2.992$ de 1989 - que permitia aos Municípios a vinculação de seus recursos transferidos -, a qual foi submetida à análise de EUNICE $\operatorname{CostA}^{468}$. A jurista entendeu que a vedação de vinculação da receitas de impostos não pode sofrer ampliação exegética, cingindo-se, portanto, tão só a esta espécie tributária dessa forma, valeria apenas para os impostos próprios, e não para a receita transferida.

A segunda interpretação que pode ser feita é que a referida lei é inconstitucional por ferir o artigo 167, IV, da Constituição Federal, ao vincular a receita dos impostos que compõem os Fundos de Participação a órgão específico. A exceção prevista ao artigo serviria apenas para a repartição destas receitas, não comportando outras hipóteses - em uma concepção restrita do artigo. Diante disso, a receita transferida não perderia o seu vínculo com a origem, ou seja, continuaria sendo considerada receita de imposto.

Entendemos que a restrição ao artigo deverá ater-se apenas à repartição das receitas, seguindo a segunda interpretação possível para o tema ${ }^{469}$. A exceção do artigo não

\footnotetext{
${ }^{467}$ Ver item 3.3.2 infra. O ponto que deve ser destacado é: "a vinculação de receita de impostos a órgão, fundo ou despesa, ressalvadas a repartição do produto da arrecadação dos impostos a que se referem os arts. 158 e 159 (...)" (destacou-se)

${ }^{468}$ Vinculação da receita: transferência, possibilidade. Revista de Direito Público. São Paulo. v. 24. n. 97. jan./mar. 1991, p. 262.

${ }^{469}$ Esta opinião também já foi exarada no item 2.3.5.1 supra.
} 
abarca vinculações com outras funções já elencadas ${ }^{470}$. Diante disto, a referida norma está conspurcada pela inconstitucionalidade. A Constituição Federal veda a vinculação da receita de impostos, não diferenciando se próprios ou transferidos; excepciona, todavia, a repartição do produto da arrecadação de impostos.

Assim, uma possibilidade de "vinculação" das receitas dos impostos oriundos do Fundo de Participação dos Estados seria para algum programa de repartição entre os municípios, razão pela qual que a expressa ressalva constitucional valeria para a hipótese aventada. Desta forma, supondo que houvesse uma lei estadual ${ }^{471}$ que separasse $12 \%$ da quota-parte a que faz o jus o Estado no Fundo de Participação dos Estados e obrigasse a sua distribuição aos municípios situados em seu território, tal repartição para o federalismo fiscal encontraria arrimo na permissão constitucional do artigo supramencionado ${ }^{472}$.

Cumpre salientar, outrossim, que o próprio parágrafo quarto do artigo 167 da Constituição Federal permite a vinculação dos impostos próprios e transferidos dos Estados, Distrito Federal e Municípios para a prestação de garantia ou contragarantia à União Federal, e não para contratações dos entes federativos com particulares. Diante disto, não seria possível o encaixe desta permissão no caso apresentado. A vinculaçãogarantia dos entes públicos aos particulares deverá ser, portanto, de receitas que não a de $\operatorname{impostos}^{473}$.

Logo, a vinculação-garantia de receitas transferidas deve guardar a motivação original desta receita; ou seja, pode ser utilizada para sua "retransferência" a outros entes federativos, caso contrário será uma burla oblíqua à não afetação de receitas. Isso porque a transferência da receita de imposto não faz com que se perca esse liame com a exação tributária: a receita será, fundamentalmente, de impostos, independentemente da finalidade a qual se presta.

\footnotetext{
${ }^{470}$ Ver item 1.5.2 supra.

${ }^{471}$ Em nossa opinião, não seriam necessárias permissões desse tipo na Constituição Estadual, pois a própria Constituição Federal já tem o condão de tornar possível que essas receitas sejam "vinculadas" para os escopos de transferência no federalismo fiscal.

${ }^{472}$ Ressalvadas, evidentemente, as demais permissões constitucionais (como a utilização de receita de imposto para garantir as AROs, dentre outras hipóteses. Ver estas observações no item 3.3.2 infra.

${ }^{473}$ Conforme já tratado no item 2.3.4.3 supra.
} 


\section{PRINCÍPIO DA NÃO AFETAÇÃO DE RECEITAS PÚBLICAS}

\subsection{PRINCÍPIOS COM RELAÇÃO ÀS RECEITAS NO DIREITO FINANCEIRO}

VIRGílio AFONSO DA SILVA ${ }^{474}$ considera que a distinção entre regras e princípios é comumente concebida de forma equivocada na doutrina pátria, principalmente em discussões que tomam como base as obras de RONALD DwORKIN e ROBERT AlEXY, que possuem outra visão acerca da diferenciação pautada pelo grau de fundamentalidade consagrada na doutrina clássica brasileira. Uma das características lançadas em seu trabalho é que os princípios expressariam deveres prima facie, enquanto que as regras seriam os deveres definitivos, ou seja, grosso modo, o resultado do cotejo entre dois deveres prima facie em uma determinada condição.

Porém, a discussão sobre a teoria dos princípios, bem como a distinção com relação às regras, não será levada em consideração - por desviar o escopo deste capítulo para uma discussão afeta à teoria geral do direito. Dessa forma, estritamente para os fins metodológicos deste trabalho, princípios e regras serão encarados como sinônimos de postulados genéricos que regem a atividade orçamentária estatal ${ }^{475}$.

Assim, os princípios de direito financeiro, segundo Horacio GuILlERMO $\mathrm{CORTI}^{476}$, "determinam o campo dos conteúdos possíveis das normas financeiras positivas

\footnotetext{
${ }^{474}$ Princípios e regras: mitos e equívocos acerca de uma distinção. Revista Latino-Americana de Estudos Constitucionais. n. 1. 2003, p. 609 e ss., especialmente 619.

${ }^{475}$ Conforme se verá no decorrer deste capítulo, ora os autores referem-se à ideia como regra da não afetação de receitas, ora como princípio da não afetação de receitas. LOUIS TROTABAS (Finances..., p. 14344), por exemplo, utiliza a não afetação de receitas junto com a expressão "regra".

${ }^{476}$ Derecho financiero. Buenos Aires: Abeledo-Perrot, 1997, p. 170.
} 
infraconstitucionais". Desta forma - continua o autor -, "os princípios seriam enunciações abreviadas, sinóticas e econômicas, cuja utilidade seria a de permitir observar com maior clareza e sistematicidade.”. Relevante também é o conceito trazido por RICARDO LOBO TORRES ${ }^{477}$ no âmbito das normas orçamentárias: "Os princípios gerais do orçamento são os enunciados genéricos que informam a criação, a interpretação e a aplicação das normas jurídicas orçamentárias." É neste sentido que relembra JOSÉ MATIAS-PEREIRA ${ }^{478}$ a importância dos princípios no controle orçamentário e da atividade financeira estatal.

Inicialmente, JACOB WILNER SUNDELSON ${ }^{479}$ demonstrou que os doutrinadores europeus preocuparam-se em sistematizar as características do orçamento em regras e princípios. A doutrina francesa entendeu que todo orçamento deveria ter certas qualidades, a saber, a unidade, anualidade, antecipação e personalidade contábil. Estas regras seriam indispensáveis para o fiel cumprimento das funções orçamentárias.

A doutrina alemã, no entanto, criticou a máxima de que estas características devam ser vistas como postulados. Diante disto, chegar-se-iam nos princípios por meio do desenvolvimento lógico do sistema político de cada país, além das teorias orçamentárias vigentes. Os princípios (e suas correspondentes exceções) seriam explicados caso a caso, denegando, portanto, concepções de valores inerentes aos princípios ${ }^{480}$.

JACOB WILNER SUNDELSON ${ }^{481}$, em sua análise, aponta então uma característica destes princípios quase sempre olvidada, qual seja: a doutrina "não julga necessário se debruçar sobre o fato de que estes princípios, exceto pelo fato de serem regras do jogo, têm grande valor como uma moldura para estudos descritivos do orçamento". Desta forma, conclui: "notamos que estes princípios estão sujeitos a mudanças; eles têm evoluído com relação a sistemas orçamentários específicos e influenciados pela visão política e outros pontos de vista dos autores que costumam apresentá-los mais ativamente."

Mais recentemente, JESSE BURKHEAD é apontado por JAMES GIACOMONI ${ }^{482}$ como um dos expoentes na doutrina anglo-saxã em minimizar a importância dos princípios orçamentários - contrariamente à tendência romano-germânica. Deveras, aponta os

\footnotetext{
${ }^{477}$ Tratado..., p. 147.

${ }^{478}$ Finanças públicas: a política orçamentária no Brasil. 3. ed. São Paulo: Atlas, 2006, p. 260.

${ }^{479}$ Budgetary..., p. 237-38. São as ideias trazidas inicialmente por LEÓN SAY e desenvolvidas posteriormente por RENÉ STOURM, GASTON JÈZE e EDGAR AlLIX.

${ }^{480}$ Cf. SunDELSON, Jacob Wilner. Budgetary..., p. 238-39. Este é o desenvolvimento da concepção de FRITZ NEUMARK.

${ }^{481}$ Budgetary..., p. $239-40$ e 263.

482 Orçamento..., p. 63-64. Esta corrente costuma ser diametralmente oposta ao enfoque dado aos princípios orçamentários pela doutrina romano-germânica, por lhes conceder menor relevância na dinâmica orçamentária.
} 
princípios mais pela sua utilidade teórica do que como mandamentos ao gestor público, visto que a sua observância nem sempre seria sinal de boa gestão orçamentária. Porém, conforme destaca o economista brasileiro, é inegável a utilidade conceitual destas regras como norteadoras da atividade orçamentária.

É importante trazer à baila que os princípios que serão tratados a seguir, em uma análise coligada ao princípio da não afetação de receitas, são aqueles que imprimem a segurança orçamentária na opinião da doutrina pátria, e, na doutrina clássica, pertencem à materialidade e ao conteúdo do orçamento. Isto porque a sua simples existência já é um fator sobremaneira importante para a segurança jurídica no sistema orçamentário ${ }^{483}$.

Por fim, não é exagerado ressaltar que ultimamente a doutrina vem se manifestando sobremaneira também em favor de princípios de ordem formal. Um deles, por exemplo, é o princípio da uniformidade, cujo escopo é padronizar as regras de orçamento e de contabilidade pública entre os diversos entes federativos, fator útil para o orçamento consolidado da Administração Pública ${ }^{484}$.

\subsection{ORIGEM E CONTEÚDO DO PRINCÍPIO DA NÃO AFETAÇÃO}

OSCAR JOSÉ DE PlÁCIDO E SILVA ${ }^{485}$ sintetizou as regras orçamentárias em veracidade, publicidade, exata correspondência (ou equilíbrio) entre a receita e a despesa, unidade, universalidade, especialização, anuidade, prevenção e personalidade. Percebe-se que, em um primeiro momento, o princípio da não vinculação de receitas não adentrava na análise de forma autônoma, mas sim com sua essência contida em outros princípios orçamentários.

A classificação de JACOB WILNER SUNDELSON ${ }^{486}$, mais completa, abarcou a não afetação como princípio autônomo. Aponta como os mais frequentes: universalidade, unidade, não afetação de receitas, autorização prévia, especificação, anualidade, precisão (ou exatidão), claridade, publicidade e exclusividade.

\footnotetext{
${ }^{483}$ Cf. SunDELSON, Jacob Wilner. Budgetary..., p. 241, expondo a classificação do jurista GASTON JÈze. Cf. também TORRES, Ricardo Lobo. Tratado..., p. 310.

${ }^{484}$ Cf. Cosciani, Cesare. Scienza delle Finanze. A cura di BISES, Bruno et al. Con il coordinamento di CAMPA, Giuseppe. Torino: UTET, c2009, p. 506.

${ }^{485}$ Noções de finanças e direito fiscal. 2. ed. São Paulo: Guaíra, [s.n.], p. 48. Esta síntese segue a opinião de doutrinadores como CAVOUR, LEON SAY, RENÉ StOURM, LEROY BEAUlieu e ROYER COLARD.

${ }^{486}$ Budgetary..., p. 240.
} 
O princípio da não vinculação ${ }^{487}$ respeita a regra geral que deve permear os orçamentos públicos: o orçamento deve revelar uma unicidade de receitas e destinação não discriminatória às despesas. Segundo FINDLAY SHIRRAS ${ }^{488}$, "o princípio geral, que cumpre seguir, é o de atender à despesa, qualquer que ela seja, com as renda gerais e não com o produto de uma fonte particular, especialmente destacada para esse fim”. Cogita-se que a origem da expressão deu-se em uma autorização (ordonnance) de 31 de maio de 1838 no ordenamento francês $^{489}$. HenRY LAUFENBURGER ${ }^{490}$ cita que o artigo 33 da Lei de 31 de maio de 1862 deste país é que dispôs precisamente acerca do instituto.

As receitas e despesas formam, assim, dois blocos distintos entre si no orçamento, não devendo haver a correlação jurídica entre um e outro de forma específica ${ }^{491}$. JosÉ MAURICIO CONTI ${ }^{492}$ ressalta que deve haver observância fiel ao referido princípio, considerando que “(...) o seu descumprimento reduz a capacidade do administrador alocar os recursos onde se mostrem mais oportunos e convenientes, o que prejudica a Administração Pública e os interesses da coletividade."

Saliente-se que a finalidade do princípio é obrigar que todos os recursos sejam alocados em um "caixa único" de cada um dos entes federativos, sem que sejam carimbados a certa despesa ou fundo especial já determinado ${ }^{493}$. Inclusive, a técnica do orçamento-programa exposta por JosÉ AFONSO DA SILVA ${ }^{494}$ é reticente quanto às vinculações, levando em conta que a sua premissa orçamentária basilar é a liberdade de recursos para fomentar a realização de obras e serviços de acordo com uma escala de

\footnotetext{
487 Também chamado de não especialização, não consignação, não gravação ou não vinculação. Em espanhol, é conhecido como no afectación. Pode-se encontrar na literatura americana como cláusula antiearmarking. JACOB WILNER SUNDELSON (Budgetary..., p. 261) trata o princípio em inglês como nonassignment of revenues, adicionando os seguintes sinônimos em diversos idiomas: non-affectation, nonassignation, Non-Affektation, Zentralisationsprinzip, Unzulässigkeit, einer Zweckbindung budgetärer Einnahmen.

${ }^{488}$ Apud RochA, Ariosto de Rezende. Rendas..., p. 66. Ver também menção em SUNDELSON, Jacob Wilner. Budgetary..., p. 261.

${ }^{489}$ Cf. TROTABAS, Louis, CotTEREt, Jean-Marie. Droit..., p. 59.

${ }^{490}$ Traité..., p. 53: "O artigo 33 da lei de 31 de maio de 1862 consagra o princípio da não afetação nestes termos: «La loi annuelle des finances ouvre les crédits nécessaires aux dépenses présumées de chaque exercice ; il est pourvu au paiement de ces dépenses par les voies et moyens compris dans le budget des recettes. »" . Cf., também, TROTABAS, Louis. Finances..., p. 117.

${ }^{491}$ Cf. MuZELLEC, Raymond. Notions..., p. 228.

${ }^{492}$ A autonomia..., p. 150.

${ }^{493}$ Cf. SILVA, José Afonso da. Orçamento-programa no Brasil. São Paulo: RT, 1973, p. 157.

${ }^{494}$ Orçamento..., p. 158.
} 
prioridades preestabelecidas ${ }^{495}$. Neste mesmo juízo, JosÉ DE RIBAMAR CALDAS FURTADO $^{496}$ prevê que a obtenção de receitas e inscrição de despesas deve obedecer a:

(...) critérios e escala de prioridades estabelecidos em função do planejamento, de modo a chegar a um orçamento-programa que reflita necessidades adequadas no tempo e no espaço, em face da realidade cambiante de cada ente governamental.

É importante destacar a opinião doutrinária de que no caso de um ordenamento que não preveja a não afetação no âmbito constitucional, não haveria sentido lógico para que constasse a previsão legal, ou por outro instrumento normativo, do princípio. DINO $\mathrm{JARACH}^{497}$ recorda que, como sua criação é ato infraconstitucional nestes casos, nada impede que o Executivo promova a desafetação de determinada despesa para o exercício respectivo ou por tempo indeterminado - e o Legislativo a sancione. Ou, então, entendemos que, pelo critério da especialidade das normas, a afetação específica de mesma hierarquia derrogaria a norma genérica da não afetação.

O princípio da não afetação pode ser inferido a partir de outros princípios, como a unidade e universalidade. Mas, caso seja oriundo de construção doutrinária, não terá a força jurídica de uma lei específica de hierarquia superior ou de uma norma constitucional $^{498}$. No Brasil, por outro lado, a não afetação apareceu explícita na Constituição e restrita a uma espécie tributária (imposto), reforçando o comando no que concerne a este tributo e enfraquecendo-o no tocante às demais espécies tributárias e outras receitas não tributárias, permitindo-se a plena vinculação delas por leis ordinárias.

Destarte, em razão destas considerações, pode-se inferir que é de bom alvitre que o princípio seja positivado constitucionalmente ou, pelo menos, por alguma norma geral de hierarquia superior à lei ordinária (como no caso das leis complementares no Brasil). Caso seja por lei ordinária, nada impedirá que ele seja derrogado pela própria lei que estabelece a afetação ou então por outra lei que derrogue a regra da não afetação de forma genérica.

\footnotetext{
495 Sebastião de SANT'AnNA E SILVA (Os princípios..., p. 29) expõe que a hierarquização e escala de prioridades nas necessidades públicas devem se dar considerando o todo do produto da arrecadação, o que é prejudicado pela vinculação específica de determinada receita. E, dado que esta hierarquização e preferência são variáveis no tempo, o melhor é que não exista o enrijecimento destas receitas por meio de instrumentos vinculatórios.

496 O problema..., p. 50.

497 Finanzas..., p. 82-83.

498 Cf. LAFERRIERE, Julien; WALINE, Marcel. Traité..., p. 95. Os autores a consideram como regra consuetudinária. Entendemos que, no caso da existência da positivação dos princípios da universalidade e unidade, a não afetação, deveras, poderá advir de regra doutrinária interpretativa.
} 


\subsection{O PRINCÍPIO DA NÃO AFETAÇÃO DE RECEITAS PÚBLICAS NO BRASIL}

\subsubsection{ESCORÇO HISTÓRICO}

No Brasil, a Lei $n^{\circ}$ 4.320/64 - segundo AUSTEN DA SILVA OLIVEIRA ${ }^{499}$ - concedia a permissão de vinculação ao legislador ordinário, uma vez que não se havia infirmado expressamente esta prática no artigo $2^{\circ}$ da mencionada norma. Consoante o autor, os únicos princípios incrustados no ordenamento naquela época eram os da unidade, universalidade e anualidade, não abarcando, portanto, o da não afetação de receitas.

Ocorre que este entendimento pode ser confrontado pela concepção integrada do princípio da unidade e universalidade, conglobando o princípio da não afetação no ordenamento jurídico. Segundo aventado por José BARBOSA DE ALMEIDA ${ }^{500}$, aqueles dois princípios vieram para assegurar o cumprimento da Constituição na faceta orçamentária.

Entendemos, portanto, que a inscrição normativa é prescindível à caracterização da existência do princípio, dada a consagração da unidade e universalidade na Lei das Finanças Públicas, a despeito de haver entendimento em sentido contrário. Outra, por exemplo, é a opinião de AUSTEN DA SILVA OLIVEIRA ${ }^{501}$ sobre o tema:

Em que pese o fato de LAFERRIÈRE e WALINE afirmarem que o princípio da não afetação de receita é apenas de construção doutrinária, não sendo uma regra de direito positivo escrito, entre nós, para sua observância, haveria que ser acolhido pela legislação constitucional ou ordinária.

Consoante já manifestado, a não afetação aparece de forma implícita no sentido de vedar, genericamente, as afetações das receitas públicas. Caso venha positivada, poderá confirmar esta regra geral ou restringir o seu âmbito de aplicação, como, por exemplo, vedando a afetação da receita apenas de tributos ou, mais especificamente, apenas a oriunda da espécie tributária imposto.

Com o advento da Constituição de $1967^{502}$, esta discussão da positivação do princípio ficou em segundo plano, já que, neste diploma, aparece de forma expressa no

\footnotetext{
${ }^{499}$ Aspectos..., p. 78-79.

500 Orçamento e política fiscal. Ensaio apresentado em concurso para a livre docência de Ciência das Finanças na Faculdade de Direito da Universidade de São Paulo. São Paulo: Max Limonad, 1964, p. 44.

${ }^{501}$ Aspectos..., p. 79.

${ }^{502}$ Cf. Silva, José Afonso da. Tributos..., p. 103. O autor explica que o princípio da não afetação apareceu de forma flexível nesta Constituição, visto que permitia vinculações que fossem estabelecidas por lei complementar.
} 
artigo 65, $\S 3^{\circ}$ e repetido, com algumas alterações, na Emenda Constitucional $\mathrm{n}^{\mathrm{o}} 1$, de 1969, em seu artigo $62, \S 2^{\circ}$, da qual se extrai o seu fundamento:

Art. 62. O orçamento anual compreenderá obrigatoriamente as despesas e receitas relativas a todos os Podêres, órgãos e fundos, tanto da administração direta quanto da indireta, excluídas apenas as entidades que não recebam subvenções ou transferências à conta do orçamento.

$\S 2^{\circ}$ Ressalvados os impostos mencionados nos itens VIII e IX do artigo 21 e as disposições desta Constituição e de leis complementares, é vedada a vinculação do produto da arrecadação de qualquer tributo a determinado órgão, fundo ou despesa. A lei poderá, todavia, estabelecer que a arrecadação parcial ou total de certos tributos constitua receita do orçamento de capital, proibida sua aplicação no custeio de despesas correntes. (destacou-se)

É importante pôr em evidência que o artigo em comento vedava a vinculação de tributo de forma genérica, restrição esta que foi modificada na atual Constituição da República. Desta forma, já se entendia que poderiam ser afetadas as receitas não tributárias, como as “(...) patrimoniais, industriais, diversas, de transferências correntes e de capital, de operações de crédito, de alienação de bens móveis e imóveis, de amortização de empréstimos concedidos, e outras receitas de capital."

Hely LOPES MEIRELLES ${ }^{504}$ entende que o princípio da não vinculação ficou parcialmente acolhido com o indigitado dispositivo constitucional, por não incluir qualquer receita, e sim somente a receita de tributo. IVES GANDRA DA SILVA MARTINS ${ }^{505}$ encarou o dispositivo como sendo uma interdição parcial, a despeito de este jurista haver tecido críticas quanto a esta alteração no ordenamento recém-concebido. Outro pormenor que se depreende é que a regra da não vinculação excepcionava o Imposto Único sobre Lubrificantes e Combustíveis Líquidos Minerais ou Gasosos, o que fomentou, por certo período, o desenvolvimento rodoviário - conforme abordado ${ }^{506}$-, bem como o Imposto sobre a Extração, Circulação, Distribuição ou o Consumo dos Minerais ${ }^{507}$.

\footnotetext{
${ }^{503}$ Cf. OliveirA, Austen da Silva. Aspectos..., p. 80. Pelo fato de haver a proibição de vinculação somente aos tributos, entende o autor que não haveria autorização para se conceber o princípio da não afetação inscrito constitucionalmente. Para ele, limitou-se o dispositivo a vedar apenas um tipo de receita (tributária), deixando possível a vinculação das demais receitas (não tributárias), como patrimoniais, industriais e oriundas de empréstimos. Apesar desta observação, não há como negar a inclusão do princípio da não afetação no seio constitucional, visto que as vinculações são utilizadas, principalmente, nas receitas tributárias, por serem as mais substanciais de uma nação. Proibindo-se a vinculação das receitas tributárias já constitui, no nosso entender, severa restrição ao legislador ordinário com relação ao montante total das receitas estatais passíveis de vinculação.

${ }^{504}$ Finanças municipais. São Paulo: RT, 1979, p. 164. Este acolhimento parcial manteve-se na Constituição de 1988 ao se vedar a afetação apenas à receita de impostos.

505 Comentários..., p. 344.

${ }^{506}$ Ver item 2.1.1 supra.

${ }^{507}$ Cf. PONTES DE MIRANDA, Francisco Cavalcanti. Comentários à Constituição de 1967: com a Emenda $n^{o}$ 1, de 1969. t. III. 2. ed. São Paulo: Revista dos Tribunais, 1971, p. 207. Os impostos únicos entram na margem deixada pela Constituição à arrecadação vinculada.
} 
Havia ainda a permissão de, mediante lei específica, vincular a receita de tributos e considerá-la como receita de capital, proibindo esta parcela de ser usada para sanar as despesas correntes. Percebe-se que, a despeito de o legislador constitucional intentar frear a atividade vinculatória do Estado, as inúmeras exceções e demasiadas modulações previstas no referido dispositivo tornaram-no débil. Diante desta cediça praxe orçamentária pátria em vincular as receitas, ARIOSTO DE REZENDE ROCHA ${ }^{508}$ concluiu que, a despeito das vastas críticas insurgidas, esta prática já estaria enraizada na cultura administrativa brasileira.

\title{
3.3.2. O PRINCÍPIO NA CONSTITUIÇÃO FEDERAL DE 1988
}

Com a Constituição de 1988, o princípio sofreu substanciais alterações em seu alcance. Atualmente, reza o preceito constitucional a vedação de afetação a órgão ${ }^{509}$, fundo ou despesa:

\begin{abstract}
Art. 167. São vedados:
IV - a vinculação de receita de impostos a órgão, fundo ou despesa, ressalvadas a repartição do produto da arrecadação dos impostos a que se referem os arts. 158 e 159, a destinação de recursos para as ações e serviços públicos de saúde, para manutenção e desenvolvimento do ensino e para realização de atividades da administração tributária, como determinado, respectivamente, pelos arts. $198, \S 2^{\circ}, 212$ e 37 , XXII, e a prestação de garantias às operações de crédito por antecipação de receita, previstas no art. $165, \S$ $8^{\circ}$, bem como o disposto no $\S 4^{\circ}$ deste artigo;
\end{abstract}

A despeito de o princípio da não consignação de receitas ter continuado a ser consagrado no ordenamento constitucional brasileiro, a própria Carta Magna estabelece vastas exceções à regra, seja no próprio inciso em que a concebe, seja por diversas emendas constitucionais que excepcionam a regra geral da não vinculação por meio de uma vinculação constitucional específica.

A não afetação não se aplica na repartição do produto da arrecadação do IR, ITR, IPVA, ICMS, IPI, consignando que tal exceção não abarca as "vinculações" para o federalismo fiscal. Desta forma, há a possibilidade de que haja a utilização destes impostos a fim de que sirvam como transferências no federalismo fiscal, quer para o Fundo de Participação dos Estados e Municípios, quer como observância de outro comando

\footnotetext{
${ }^{508}$ Rendas..., p. 68.

${ }^{509}$ Neste caso, não se incluem os órgãos paraestatais, conforme visto no item 1.4.3 supra.
} 
normativo que preveja esta suposição - como na hipótese de lei estadual destinar a quotaparte que lhe cabe do FPE para distribuir aos municípios situados em seu território ${ }^{510}$.

Ademais, há também a previsão de ressalva no caso de destinação de recursos para as ações e serviços públicos de saúde, manutenção e desenvolvimento do ensino e realização de atividades da administração tributária. Nos dois primeiros casos, excepcionam-se as "vinculações" - despesas obrigatórias - para saúde e educação, demonstrando que a Carta Magna lida vulgarmente com os dois conceitos ao tratá-los como sinônimos.

Também não se aplica quanto à prestação de garantias às operações de crédito por antecipação de receita orçamentária (AROs). Outrossim, não se verifica quanto à prestação de garantia ou contragarantia à União e para o pagamento de débitos para com esta com relação ao ITCMD, ICMS, IPVA, IPTU, ITBI e ISS e, também, no tocante ao produto da repartição de verbas para o federalismo fiscal. Desta forma, também considera possível a vinculação-garantia da receita de impostos em algumas modalidades estabelecidas.

Com as alterações trazidas pela Emenda Constitucional n ${ }^{\circ} 42$, de 2003, o princípio da não afetação é ressaltado por José MAURICIO CONTI ${ }^{511}$ como "a proibição de se vincular receita de impostos a órgão, fundo ou despesa. A proibição não atinge os demais tributos, mas apenas os impostos; isto se deve à própria característica intrínseca a esta espécie tributária (...)", nos termos da dicção do artigo 16 do codex tributário, cuja análise deve dar-se em consonância com o preceito constitucional insculpido no artigo 167, IV, da Constituição Federal ${ }^{512}$.

Assim, a regra da não vinculação cristalinamente atinge tão somente os impostos $^{513}$. Outras espécies tributárias não estariam abrangidas nesta regra, pois taxas e contribuições de melhoria seriam, a priori, vinculadas por sua natureza específica ${ }^{514}$.

\footnotetext{
${ }^{510}$ Ver item 2.3.5.3 supra.

${ }^{511}$ Direito..., p. 103. O autor ressalta que o imposto é um tributo não vinculado, não existindo qualquer liame entre o Estado e o contribuinte no sentido de afetar esta receita a determinada atividade.

512 O Superior Tribunal de Justiça não analisa o mérito da vinculação de receitas quando é levantada a alegação de afronta ao dispositivo do Código Tributário Nacional mencionado, entendendo pela relação de pertinência unicamente ao plano constitucional, como no Agravo Regimental no Agravo de Instrumento $\mathbf{n}^{\mathbf{0}}$ 708.466/SP. 2 ${ }^{\text {a }}$ Turma. Rel. Min. João Otávio de Noronha. j. 6. dez. 2005. DJU 1 fev. 2006.

513 Aliás, assinala SEBASTIÃo DE SANT'ANNA E SILVA (Os princípios..., p. 27), com base nos estudos de GASTON JÈZE, que o princípio da não afetação, desde os seus primórdios, só poderia jungir-se aos impostos, dadas as peculiaridades dos demais tributos que, fatalmente, teriam sua natureza coligada a uma determinada vinculação.

514 Cf. JuAno, Manuel de. Curso..., p. 392. O autor também entende desta forma, ao dizer que as contribuições de melhoria (local assessment) são admitidas como tributos com afetação financeira, já que se visa, sobretudo, a pagar a obra pública que ensejou a melhoria de determinada região. Desta forma, por decorrência lógica, a vinculação deve ser específica.
} 
Algumas contribuições dependem de destinação constitucional (CIDE-Combustíveis) e os empréstimos compulsórios possuem destinação definida no momento de sua instituição ${ }^{515}$.

É possível, diante disto, afirmar ser plenamente viável a vinculação de receitas não tributárias, inclusive como já previam JULIEN LAFERRIÈRE e MARCEL WALINE ${ }^{516}$ no ordenamento francês com as rendas das loterias. Logo, haveria como se vincular outras rendas - tais como os preços públicos - a contrario sensu do disposto no artigo 167, IV, da Carta Magna.

Caso assim não fosse, poderia ocorrer a esdrúxula conclusão de que uma empresa estatal prestadora de serviço público não conseguiria vincular a tarifa auferida à sua atividade, devendo ser remunerada por outra forma; ou, então, deveria repassar o produto da sua arrecadação ao Poder Executivo para que então fosse incluído no orçamento geral e posteriormente redistribuído a esta estatal. Logo, inconteste é que outras espécies tributárias e não tributárias sejam perfeitamente vinculáveis.

Este também é o entendimento de RICARDO LOBO TORRES ${ }^{517}$ ao dizer que a restrição é explícita aos impostos - diferentemente do que ocorria em 1967 e 1969, quando abrangia a totalidade de tributos - sendo também seguido por FERNANDO FACURY SCAFF ${ }^{518}$ e JOSÉ CRETELLA JÚNIOR ${ }^{519}$, lembrando que a expressão produto da arrecadação equivale, nesse caso, à receita dos impostos. A jurisprudência, em regra, manifesta-se pela não aplicação do princípio a outros tributos que não os impostos ${ }^{520}$, máxime quando se analisam as vinculações das contribuições ${ }^{521}$.

Na ADI 2.123-1/ES ${ }^{522}$, em sede de liminar, o Ministro Sepúlveda Pertence analisou que, diferentemente da Carta anterior que restringia a tributos, a nova

\footnotetext{
${ }_{515}$ Cf. OliveiRA, Regis Fernandes de. Curso..., p. 353.

516 Traité..., p. 97-98.

517 Curso de Direito Financeiro e Tributário. 8. ed. Rio de Janeiro: Renovar, 2001, p. 106 e Tratado..., p. 336.

${ }^{518}$ As contribuições..., p. 59.

${ }^{519}$ Comentários à Constituição Brasileira de 1988. Rio de Janeiro: Forense, 1989, p. 3820.

520 Cf. SCAFF, Fernando Facury. Para além..., p. 1140. O autor ressalva, entretanto, que “(...) o Supremo Tribunal Federal, mesmo após o advento da Constituição Federal de 1988, continuou interpretando o preceito da não-vinculação como sendo aplicável aos tributos em geral, e não apenas aos impostos."

521 Pode-se verificar tal entendimento em recente aresto do Tribunal Regional Federal da Terceira Região. AC 2002.61.03.005208-5. 3 ${ }^{\mathrm{a}}$ Turma. Rel. Juíza Cecília Marcondes. j. 15 mai. 2008. DJU 27 mai. 2008: "CONSTITUCIONAL - TRIBUTÁRIO - CONTRIBUIÇÃO AO SEBRAE - LEI 8.029/90 CONSTITUCIONALIDADE - DESNECESSIDADE DE LEI COMPLEMENTAR - CONTRIBUIÇÃO DE INTERVENÇÃO NO DOMÍNIO ECONÔMICO - INTELIGÊNCIA DO ARTIGO 149 DA CONSTITUIÇÃO FEDERAL. (...) II - Tratando-se de contribuição, e não de imposto, não há que se falar em infringência aos artigos 154, I, e 167, IV, ambos da Constituição Federal. (...)". Também neste sentido, TRF $3^{\mathrm{a}}$ Região. AC 2003.61.08.005302-8. 3 $3^{\mathrm{a}}$ Turma. Rel. Juíza Cecília Marcondes. j. 15 mai. 2008. DJU 27 mai. 2008.

${ }^{522}$ Pleno. Rel. Min. Marco Aurélio. j. 6 jun. 2001. DJU 21 jun. 2001, p. 128.
} 
Constituição limitava-se simplesmente aos impostos. Também merece menção o caso paradigmático de vinculação de receita a órgão ocorrido com a Lei paulista $\mathrm{n}^{\circ}$ 6.374/89, pouco depois da promulgação da nova Constituição que manteve a vedação de vinculação da receita para os impostos. Por meio de uma majoração na alíquota do ICMS de 17\% para $18 \%$, este $1 \%$ adicional era vinculado à Caixa Econômica do Estado S/A a fim de financiar programas habitacionais no Estado. O Supremo Tribunal Federal pacificou a questão, entendendo pela inconstitucionalidade nesta vinculação ${ }^{523}$.

Por fim, é importante relembrar que, ainda que positivado constitucionalmente, o princípio da não afetação da receita de imposto não configura cláusula pétrea, de forma que poderão ser criadas exceções por via de emendas constitucionais, o que, aliás, tem sido feito com muita frequência após o advento da Constituição de $1988^{524}$.

Defronte estas considerações, pode-se dizer que a não afetação de receitas públicas proclama a vedação do estabelecimento de vínculo - entre uma fonte a determinado destino - a fim de que o total das receitas faça frente às despesas de forma genérica.

No Brasil, é inscrito constitucionalmente no artigo 167, inciso IV, da Constituição Federal, circunscrevendo esta proibição somente à espécie tributária “imposto". Paralelamente, é relevante considerar que o dispositivo considera vulgarmente as repartições para o federalismo fiscal e as despesas obrigatórias como vinculações, e vislumbra as afetações com função de garantia no ordenamento brasileiro, excepcionando da regra geral estas hipóteses expressamente consignadas.

\subsection{RAZÕES DA EXISTÊNCIA DO PRINCÍPIO DA NÃO AFETAÇÃO}

Diferentemente dos princípios da unidade e universalidade - que serão analisados a posteriori - SEBASTIÃO DE SANT'ANNA E SILVA ${ }^{525}$ explica que o princípio da não afetação não era uma das reivindicações políticas do Legislativo; desta forma, sua existência está calcada, principalmente, na conveniência orçamentária da Administração Pública em “(...) poder dispor livremente da massa das receitas para a elaboração do seu programa orçamentário anual (...)". Consequentemente, o Parlamento deteria maior poder

\footnotetext{
${ }^{523}$ RE 183.906-6/SP. Rel. Min. Marco Aurélio. j. 18 set. 1997. DJU 30 abr. 1998.

${ }^{524}$ Cf. ConTI, José Mauricio. A autonomia..., p. 150. Ver também item 1.2, “c”, supra.

525 Os princípios..., p. 26-27.
} 
fiscalizatório na destinação orçamentária, além de ser possível, pela atividade legislativa, promover melhor discussão e destinação dos recursos de acordo com as políticas públicas consideradas mais importantes.

O princípio da não consignação de receitas soergue, portanto, como corolário de uma concepção neutra das finanças públicas, fazendo com que os recursos públicos constituam a massa única financeira estatal ${ }^{526}$. É preocupação antiga da doutrina ${ }^{527} \mathrm{em}$ justificar a existência de sua positivação nos ordenamentos jurídicos, apesar de outra parcela entender ser construção doutrinária, conforme já mencionado ${ }^{528}$. Desta forma, a doutrina jurídica costuma negar os benefícios econômicos ${ }^{529}$ advindos das vinculações: é sob esta premissa neutra que origina a justificativa do princípio da não vinculação.

Segundo a doutrina, a questão orbita principalmente os limites da discricionariedade ${ }^{530}$ na alocação dos gastos públicos, visto que para essa corrente seria uma atitude incorreta escolher uma despesa, dentre todas as existentes em um Estado, como extraordinária e merecedora de um tratamento diferenciado, submetendo-a a um orçamento paralelo ao geral do Estado ${ }^{531}$.

Traçado este panorama, convém salientar que Michel BOUviER, MARIECHRISTINE ESCLASSAN e JEAN-PIERRE LASSALE ${ }^{532}$ expressam, em princípio, que o conjunto de receitas serve para custear o conjunto de despesas. São três as justificativas dadas pelos autores e pela doutrina em geral para que haja a consagração da não afetação.

A primeira é jurídica: o sistema de afetação pode levar a certa despesa ficar dependente de uma receita de forma indeterminada, já que as receitas são auferidas de forma aproximativa ${ }^{533}$. Tendo em vista que a estimação de receitas nunca é rígida e $\operatorname{limitada}^{534}$, caso se permita a vinculação de uma receita a determinada despesa, o montante

\footnotetext{
${ }^{526}$ Cf. LAUfEnBurger, Henry. Traité..., p. 53.

${ }^{527}$ Cf. CATÃo, Marcos André Vinhas. Novas..., p. 577. A despeito de o autor destacar a opinião do jurista francês RAYMOND FERRETTI sobre as razões do princípio serem técnicas e políticas, ver-se-á que a doutrina já se debruçava quanto a estas justificativas, incluindo, outrossim, outras mais.

${ }^{528}$ Ver item 3.2 supra.

${ }^{529}$ Ver item 1.1 supra.

${ }^{530}$ Há uma linha tênue que distingue a discricionariedade do desvio de poder, que seria a definidora dos limites da discricionariedade estatal. MANUEL DE OLIVEIRA FRANCO SOBRINHO ( $O$ controle da moralidade administrativa. São Paulo: Saraiva, 1974, p. 180) adverte para "que se marquem, no entanto, duas situações: a) a discricionariedade, como faculdade, é aquela permissão que se concede à Administração de agir ou deixar de agir dentro de um limite estabelecido pela regra jurídica; b) o desvio de poder, como atividade é aquela ação efetivada longe do espírito da lei, ou melhor, exercitada fora do fim previsto, qualificado como finalidade própria do ato." (destaques do original)

${ }^{531}$ Cf. TROTABAS, Louis. Finances..., p. 120. Esta seria a razão, também, para a existência dos princípios da unidade e universalidade, que serão tratados a seguir. Ver, respectivamente, itens 3.5.1.1 e 3.5.2.1 infra.

${ }^{532}$ Finances Publiques. 7. ed. Paris: L.G.D.J., 2004, p. 259.

${ }^{533}$ Cf. MuZELleC, Raymond. Notions..., p. 228.

${ }^{534}$ Ver item 1.7 supra.
} 
necessário de receita prevista poderá não ser suficiente, fazendo com que a autorização de despesas seja mera suposição e varie de acordo com o recurso afetado ${ }^{535}$.

Nesta esteira, entende FERNANDO SAINZ DE BUJANDA ${ }^{536}$ que a afetação das receitas corriqueiramente acarretaria o déficit estatal quando do ingresso insuficiente para o custeio destes serviços nos quais haja afetação. JOSÉ JOAQUIM TEIXEIRA RIBEIRO ${ }^{537}$, com um exemplo elucidativo, registra esta problemática de ordem jurídica:

E se a receita é de montante incerto, como sucede na generalidade dos casos, a sua afetação a uma despesa põe esta na contingência de ter de ser menor que o crédito orçamental. Por exemplo, prevê-se um imposto de 100000 contos e destina-se esse imposto à cobertura de igual despesa. Como a receita depois cobrada pode ser de 100 000, 110000 ou 90 000, aí temos que o crédito orçamental pode ser integralmente utilizado quando a receita produza 100000 ou 110000 contos, mas só pode ser utilizado em 9/10 quando a receita produza 90000.

A segunda explicação é técnica. Se o serviço ou atividade possui, em seu favor, receitas superiores ao necessário, a tendência é que a Administração equilibre esta relação receitas/custos, favorecendo que os recursos sejam menos eficazmente utilizados ${ }^{538}$. E caso haja superávit primário, a vinculação de receitas impediria que ele fosse revertido em favor do custeio da dívida pública estatal ${ }^{539}$. Ressalte-se que, em homenagem ao princípio da eficiência na Administração Pública, essa consequência, presumidamente, não deveria ocorrer, de forma que a argumentação técnica não teria o condão de invalidar, per se, a prescrição principiológica da não vinculação.

Por último, a justificação política agrega a propriedade libertária do princípio, fazendo com que o Estado não se encontre acorrentado em suas próprias finanças e vinculações, analogamente ao titã Prometeu ${ }^{540}$. Ademais, faz com que as verbas públicas sejam encaradas como um conjunto, inclusive quanto aos recursos obtidos e a deliberação de sua destinação para cobrir os gastos estatais ${ }^{541}$. Caso contrário, ver-se-ia uma

\footnotetext{
${ }^{535}$ Cf. BouvIER, Michel; Esclassan, Marie-Christine; LASSALE, Jean-Pierre. Finances..., p. 259.

${ }^{536}$ Notas..., p. 634.

${ }^{537}$ Lições..., p. 64.

538 Cf. Bouvier, Michel; Esclassan, Marie-Christine; Lassale, Jean-Pierre. Finances..., p. 259. Cf. também DUVERGER, Maurice. Finances..., p. 320.

${ }^{539}$ Cf. SAINZ DE BujAndA, Fernando. Notas..., p. 635. Esta seria uma das razões para o surgimento da Desvinculação de Receitas da União - DRU. Ver item 4.2.2 infra.

${ }^{540}$ Cf. OliveIRA, Regis Fernandes de. Curso..., p. 337: "O salutar princípio significa que não pode haver mutilação das verbas públicas. O Estado deve ter disponibilidade da massa de dinheiro arrecadado, destinando-os a quem quiser, dentro dos parâmetros que ele próprio elege como objetivos preferenciais. Não se pode colocar o Estado dentro de uma camisa de força, minguando seus recursos, para que os objetivos traçados não fiquem ou não venham a ser frustrados. Deve haver disponibilidade para agir."

${ }^{541}$ Cf. BouvIER, Michel; EsClASSAN, Marie-Christine; LASSALE, Jean-Pierre. Finances..., p. 259.
} 
hierarquização ${ }^{542}$ e cristalização das despesas públicas: a primeira em razão do desrespeito ao pensamento de que todas as despesas atendem ao interesse público; a segunda tendo em vista que os interessados nunca iriam querer abrir mão desta benesse, esvaindo-se o princípio da solidariedade e unidade nacionais ${ }^{543}$.

Se hipoteticamente os recursos não fossem aplicados genericamente, FERNANDO SAINZ DE BUJANDA ${ }^{544}$ lembra que se perderia o sentido de coletividade e solidariedade que deve permear na sociedade. Seria, na realidade, um ato de egoísmo dos cidadãoscontribuintes que, ao pagarem os impostos, já predeterminariam o gasto, satisfazendo necessidades setoriais em detrimento do interesse coletivo. Por outro lado, a vinculação de receitas tem um efeito sócio-psicológico já exposto: facilita a aceitação do contribuinte na cobrança do imposto, principalmente aqueles com certa carga extrafiscal ${ }^{545}$.

Finalmente, quanto ao aspecto financeiro e de contabilidade pública, pode-se ressaltar que a legalidade dos atos normativos que permitem auferir determinada receita independe da legalidade dos atos orçamentários (ordenações de despesas), coligados a uma despesa específica ${ }^{546}$. Já no que concerne à contabilidade pública, a não afetação permite que, com o produto da arrecadação ingressando integralmente e sem distinções no orçamento, sejam aplicáveis, uniformemente, as regras contábeis a todas as receitas ${ }^{547}$.

Percebe-se, destarte, que as razões invocadas para a existência da não afetação remetem ao trade-off da vinculação pelo seu lado crítico, descartando qualquer efeito benéfico que se possa ter com as afetações. É por conta disto que o princípio da não vinculação, por vezes, acaba sendo relativizado, o que será visto posteriormente ${ }^{548}$.

\footnotetext{
${ }^{542}$ Este conceito, para RAFAEL CALVO ORTEGA (Curso de derecho financiero. 7 ed. Madrid: Thomson Civitas, 2003, p. 81), não tem caráter científico, visto que não há, a priori, hierarquia ou preferência entre o gasto público. Diante disto, conclui que não passa de um fenômeno de ilusão financeira.

${ }_{543}$ Cf. MuZELleC, Raymond. Notions..., p. 228 e ver a influência dos grupos de interesse no item 1.3 supra. ${ }^{544}$ Notas..., p. 634.

${ }^{545}$ Cf. BouvIER, Michel; EsClassan, Marie-Christine; LASSALE, Jean-Pierre. Finances..., p. 259-60 e nt. 6. Os autores citam a menção de PHILIP ao dizer que a não vinculação "é um incômodo ao impedir, por exemplo, a afetação de uma parte dos impostos sobre o álcool para a luta contra o alcoolismo, os impostos sobre o tabaco para a luta contra o câncer". Indicam, outrossim, a Decisão 152 DC do Conselho Constitucional que acolheu a vinculação à Caixa Nacional de Auxílio-Doença aos trabalhadores assalariados, pois não se tratava do Estado, e sim de um estabelecimento público. Segundo EWAN CLAGUE e JOEL GORDON (Earmarking..., p. 13), estes tributos são chamados de impostos de luxo, possivelmente voltados à ideia puritana de que estes vícios devam ser tributados a fim de compensar os necessitados.

${ }^{546}$ Com relação a essa questão tributária, ver item 4.2.2.2 infra.

${ }^{547}$ Cf. LAFERRIÈRE, Julien; W ALINE, Marcel. Traité..., p. 95-96.

${ }^{548}$ Ver itens 1.6 supra e 3.7 infra.
} 


\subsection{RELACIONAMENTO DO PRINCÍPIO DA NÃO AFETAÇÃO COM OS PRINCÍPIOS DA UNIDADE E UNIVERSALIDADE}

Em meados da década de trinta do século passado, JACOB WILNER SUNDELSON ${ }^{549}$ já apontava que a literatura costumava construir a ideia da não afetação em uma concepção umbilical à unidade $\mathrm{e}$ universalidade. $\mathrm{O}$ autor estadunidense, ao condensar as classificações de FrITZ NEUMARK e GASTON JÈZE sob uma faceta estática do orçamento, sintetiza que o princípio da não afetação, juntamente com o da unidade, seria a sua característica material. A unidade, junto com a claridade, apareceria na característica formal $^{550}$. Atento a isto, JULIo BANACLOCHE PEREZ ${ }^{551}$ também os alcunha como princípios formais: a não afetação, universalidade, unidade e especificação orçamentária seriam a consagração desta peculiaridade orçamentária.

JACOB WILNER SundELSON ${ }^{552}$ demonstra que JOHANNES SEIDEL também intenta agrupar os princípios, mas, de forma alternativa, utiliza-se de perguntas cujas respostas são os próprios princípios orçamentários. A universalidade satisfaria a pergunta: “o que o orçamento deve incluir?". A unidade, a "em que maneira deve o orçamento demonstrar os gastos e receitas que ele contém?”. Em complemento a isso, pensamos que a não vinculação poderia solucionar a questão “como as receitas públicas devem fazer frente às despesas?".

Posteriormente a estas análises, o autor americano propõe classificação própria, agrupando os princípios em três categorias: a) relação entre o sistema orçamentário e a atividade financeira da unidade política: nesta se situaria a universalidade; b) a maneira pela qual o método orçamentário aplicado trata os fatores do sistema orçamentário: a unidade é um exemplo; e c) formas e técnicas de apresentação do orçamento: a clareza faz parte desta categoria ${ }^{553}$. Acreditamos ser esta uma boa forma de agrupá-los, a fim de evitar a dicotomia entre materialidade e formalidade dos princípios exposta acima.

Após estes engenhos incipientes, muito se discutiu na Europa, na primeira metade do século XX, acerca da localização do princípio da não afetação - tendo em vista a sua ubiquidade entre os princípios orçamentários -, instaurando-se a celeuma doutrinária. Divergem os autores quanto à sua caracterização junto ao princípio da unidade ou da

\footnotetext{
${ }^{549}$ Budgetary..., p. 261. Aponta como exemplos doutrinários MASÉ-DARI e LOTZ (nt. 64).

${ }^{550}$ Cf. SundELSON, Jacob Wilner. Budgetary..., p. 242.

${ }^{551}$ Manual de economía financiera. Madrid: Derecho Financiero, 1971, p. 279-80.

${ }_{552}^{5}$ Budgetary..., p. 242.

${ }^{553}$ Cf. SundELSON, Jacob Wilner. Budgetary..., p. 243.
} 
universalidade $^{554}$, havendo também quem o entenda como um princípio autônomo, sendo objeto de verdadeiras quizilas doutrinárias.

Outro ponto é com relação à positivação dos princípios. HECTOR BELISARIO VILLEGAS ${ }^{555}$ entende, $v . g$., que a regra da unidade é produto do pensamento doutrinário, e não de disposições do direito positivo, visto ser imperioso que o orçamento seja apreciado em seu conjunto para dificultar a dissimulação ou ocultamento de gastos. MANUEL DE JUANO $^{556}$, neste diapasão, registra que a maioria dos autores entende que a regra da unidade não é imposta via legislativa, mas sim inferida da natureza ínsita do orçamento. Não há como concebê-lo sem o princípio da unidade, por decorrência lógica do sistema dos países que adotam a sistemática de elaboração de uma peça orçamentária. Haveria, decerto, diversos inconvenientes caso não existisse uma peça única e o Parlamento tivesse que votar diversas leis que tratassem das receitas e despesas.

No entanto, entendemos ser de boa recomendação a positivação dos princípios da unidade e universalidade, por representarem o mínimo conceitual que deve reger a atividade orçamentária moderna. Seria árduo obrigar uma nação a respeitá-los sem a existência de sua inscrição no ordenamento jurídico, podendo ensejar o surgimento de orçamentos anexos ou contas especiais, bem como a inscrição das receitas pelo valor líquido. A positivação destas regras, inclusive, pode contribuir para o reconhecimento implícito do princípio da não afetação, além de outros correlatos.

Outrossim, nem ao menos é pacífico o entendimento da existência de autonomia entre os princípios da unidade e universalidade, existindo inclusive defesas no sentido de

\footnotetext{
${ }^{554}$ Esta dúvida na classificação é exposta por SEBASTIÃo DE SANT’ANNA E SILVA (Os princípios..., p. 27), optando o autor pela relação da não afetação com o princípio da unidade orçamentária.

${ }_{555}$ Curso..., p. 129.

556 Curso..., p. 386-88. O autor argentino relata estes inconvenientes, os quais merecem registro: “a) A unidade orçamentária permite com maior facilidade observar se um orçamento mantém-se equilibrado. Se, pelo contrário, os recursos e gastos distribuem-se em diversos orçamentos, o déficit pode dissimular-se e ocultar-se com maior probabilidade. b) Este inconveniente agrava-se quando certos gastos estatais não se publicam ainda que figurem em contas marginais ao orçamento. Tal fato ocorria nas 'contas especiais' ou com os chamados 'serviços especiais do Tesouro'. c) Tais orçamentos conduzem à ilusão, com passos e contrapassos de que se estão logrando economias, quando isso não ocorre realmente. d) A unidade do orçamento é necessária para poder determinar qual é o montante e volume do orçamento, isto é, saber com certeza quais são os montantes dos gastos públicos e que recursos devem se estabelecer, sem fazer com que seja extremamente pesada a carga ao povo contribuinte. e) A unidade orçamentária é a única que permite comparar, à autoridade que vota o orçamento, o montante dos recursos necessários, já que é essencial que todos os créditos e partidas sejam votados simultaneamente. Destarte, é possível observar quais são os créditos menos urgentes ou úteis. f) A unidade orçamentária evita complicações e obscuridades. Quando o orçamento se parcela em vários documentos, nem os próprios especialistas em finanças conseguem conhecer com exatidão o estado das finanças públicas. g) Ademais, se as partidas excluídas do orçamento não se submeterem à votação do Parlamento, além dos inconvenientes financeiros, agregar-se-iam os de ordem política, dado que uma parte das finanças públicas escaparia da autorização e controle dos representantes do povo. Ainda que, em verdade, esta hipótese, consoante a experiência vivida, seria mais teórica do que prática."
} 
que a universalidade seja complementária à unidade no seu aspecto de produto bruto $^{557}$, bem como outras concepções integrativas que serão vistas posteriormente ${ }^{558}$.

No ordenamento pátrio, é importante mencionar que ESTEVÃo HoRVATH ${ }^{559}$ observou que o artigo $4^{\circ}, \S 2^{\circ}$, da LRF, ao tratar do Anexo de Metas Fiscais, reafirmou a efetividade dos princípios da unidade e universalidade, talvez - conjecturamos - em virtude do constante esquecimento de seu cumprimento pelos gestores públicos.

\subsubsection{PRINCÍPIO DA UNIDADE ORÇAMENTÁRIA E SEU RELACIONAMENTO COM A NÃO AFETAÇÃO}

A unidade orçamentária é, consoante magistério de GERALDO ATALIBA ${ }^{560}$, a simplicidade orçamentária. Sucintamente, conceitua Helio SAUL Mileski ${ }^{561}$ que tal princípio veda a feitura de mais de um orçamento em cada ente público, facilitando, destarte, a fiscalização política desta atividade. Isto ocorre porque não deve haver itens considerados apartados das finanças ordinárias estatais ${ }^{562}$.

Há autores, como FERNANDO PÉREZ ROYO ${ }^{563}$, que estendem esta característica do orçamento único também a administrações ou agentes que compõem o Estado; para OSCAR JosÉ DE PlÁCIDO E SILVA ${ }^{564}$, o princípio da unidade impediria a criação de vários orçamentos, evitando a existência de diversas administrações especiais do Estado. JACOB WILNER SUNDELSON ${ }^{565}$ relata que a doutrina identifica o princípio como "marca de disciplina e saúde financeira que estudantes da ciência das finanças associam a sua não observância com práticas obscuras e duvidosas".

A latere destas considerações, o HECTOR BELISARIO VILLEGAS ${ }^{566}$ desfere críticas às afetações de receitas, dado que mutilam justamente a regra da unidade, acarretando prejuízos ao ingresso dos recursos em um fundo único:

\footnotetext{
${ }^{557}$ Cf. TROTABAS, Louis; Finances..., p. 122.

${ }_{558}^{55}$ Ver item 3.5.3 infra.

559 A Constituição e a Lei Complementar no 101/2000 ("Lei de Responsabilidade Fiscal”). Algumas Questões: In: RochA, Valdir de Oliveira. Aspectos relevantes da Lei de Responsabilidade Fiscal. São Paulo: Dialética, 2001, p. 157.

${ }^{560}$ Apontamentos de ciência das finanças, direito financeiro e tributário. São Paulo: Revista dos Tribunais, 1969, p. 54.

${ }^{561}$ O controle da gestão pública. São Paulo: RT, 2003, p.50.

${ }^{562}$ Cf. SundELSON, Jacob Wilner. Budgetary..., p. 248.

${ }^{563}$ Derecho..., p. 368.

${ }^{564}$ Noções..., p. 51.

${ }^{565}$ Budgetary..., p. 248.

${ }^{566}$ Curso..., p. 131.
} 
As afetações especiais são perniciosas e atacam o princípio da unidade, uma de cujas condições é que os gastos do Estado sejam atendidos indiscriminadamente com o conjunto dos fundos do erário público. A existência de afetações especiais lesiona essa regra porque não se cumpre a centralização de todos os ingressos em um único fundo.

Sagazmente, o jurista expressa que a proliferação das práticas de afetações especiais, além de desorganizar o sistema orçamentário, "ataca em seu ponto neurálgico de sua unidade." 567 É o que ocorre na Argentina com as leis especiais que dispõem sobre requisitos para se lograr afetações específicas (Decreto 2629/92).

Este ideal, inclusive, estava presente, ao menos virtualmente, nos princípios da Revolução de $1789^{568}$. Foi concebido, deveras, como uma maneira de o Parlamento obter maior controle sobre as operações financeiras ${ }^{569}$. No direito estadunidense, também a consolidação do orçamento era vista como única forma possível de unificar a política orçamentária nos países em desenvolvimento ${ }^{570}$.

NiCO GROENENDIJK ${ }^{571}$ entende que a regra da não afetação estaria intimamente conectada ao princípio da unidade, assim como a regra da não compensação com o princípio da universalidade. Segundo o autor:

O princípio da não afetação determina que nenhuma receita deve ser afetada para um gasto determinado. Em outras palavras: a vinculação não é permitida. Obviamente, este princípio é conectado com a regra da unidade (como ocorre na regra da não compensação com a regra da universalidade): violações da regra da não afetação muitas vezes significam a formação de orçamentos especiais, ou em regra conduzem a diferentes tratamentos de diferentes grupos de gasto e/ou receita.

Outros doutrinadores, como RAMÓN FALCÓN Y TELLA ${ }^{572}$, também abarcam o princípio da não vinculação ao princípio da unidade, entendendo-os como princípios

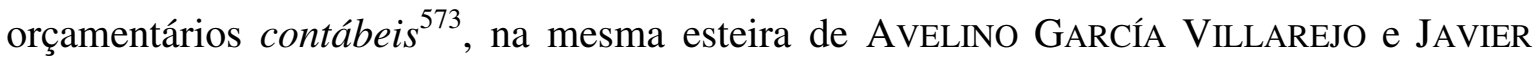

${ }^{567}$ Cf. VILlegas, Hector Belisario. Curso..., p. 132.

${ }^{568}$ Cf. SAY, León. Dictionnaire..., p. 658.

${ }^{569}$ Cf. Silva, Sebastião de Sant'Anna e. Os princípios..., p. 20.

${ }^{570}$ Cf. Prest, Alan Richmond. Public finance in underdeveloped countries. New York: Praeger, [1963, c1962], p. 123.

${ }^{571}$ Budgetary discipline in Brussels: numerical targets or procedural rules? Pittsburgh: ECSA Sixth Biennial International Conference, 1999, p. 10-12 e 13. Disponível em: <http://aei.pitt.edu/2279/01/002627_1.PDF>. Acesso em: 20 out. 2008. Pode ser considerado sinônimo do princípio do orçamento bruto, que será tangenciado neste trabalho. Segundo o autor, concebe-se a ideia de que o orçamento deva ser bruto, com as despesas e receitas claramente definidas no documento, de forma a não escapar do controle da atividade fiscal. Ver também item 3.5.1.2 infra.

572 Introducción al derecho financiero y tributario de las comunidades europeas. Madrid: Civitas, 1988, p. 355 e ss.

${ }^{573}$ Cf. Gomes, Emerson Cesar da Silva. Da contabilidade. In: ConTI, José Mauricio (coord.). Orçamentos..., p. 255-56. O autor relembra, sabiamente, que a Lei de Responsabilidade Fiscal, no artigo 50, I, evidencia que os recursos vinculados devem obedecer aos corolários da Contabilidade Pública. Esta ciência faz, portanto, 
SALINAS SANCHEZ ${ }^{574}$. Isto porque "só é possível vincular recursos a um órgão, fundo ou despesa se houver registro individualizado das fontes de recursos que integram esta vinculação" ${ }^{\text {"575 }}$ (destacou-se)

Dessarte, resta sobremaneira destacado o relacionamento do princípio da não afetação com a unidade: ora se concebe a não afetação como consequência do desrespeito à unidade, ora como a própria violação contábil desta regra. Ocorre que nem sempre a afetação acarretará uma transgressão à unidade. Cite-se, hipoteticamente, uma afetação de parcela da receita de um imposto para a compra de livros escolares instrumentalizada mediante um fundo. Neste caso, conforme se verá, o fundo é considerado dentro da unidade de desígnios que exige a atividade orçamentária, não sendo concebido como um “corpo estranho" no orçamento. As receitas, apesar de segregadas, continuarão a ser contempladas dentro do orçamento único do Estado.

\subsubsection{FUNDAMENTO E EXCEÇÕES À UNIDADE}

Há duas razões para a existência da unidade orçamentária, segundo JEAN-MARIE Auby e RoBERT DuCOS-ADER ${ }^{576}$. Uma delas é a política, isto é, a facilidade de controle das contas públicas pelo Parlamento ${ }^{577}$. A outra é técnica, dado que, com um documento donde se extrai o volume total de receitas, evitam-se remissões a documentos externos. Nesta mesma toada, JULIO BANACLOCHE PEREZ ${ }^{578}$ fundamenta o princípio da unidade nas seguintes características:

\footnotetext{
- apreciar facilmente o equilíbrio, ou não, do orçamento.

- dificultar as manobras contábeis.

- expressar exatamente a magnitude e proporções do orçamento.

- ser claro e facilitar o controle
}

com que se assegure que as receitas vinculadas sejam aplicadas nos programas que ensejaram a respectiva vinculação, sem que haja desvios de finalidade por parte do Poder Público.

${ }^{574}$ Manual de hacienda publica. General y de España. Madrid: Tecnos, 1985, p. 177.

${ }^{575}$ Cf. GoMes, Emerson Cesar da Silva. Da contabilidade..., p. 287.

${ }^{576}$ Droit publique. 3. ed. Paris: Sirey, 1969, p. 21-22.

${ }^{577}$ Cf., neste sentido, VILlEGAS, Hector Belisario. Curso..., p. 129: “A regra da unidade do orçamento tende a possibilitar o melhor cumprimento das faculdades do Parlamento com relação ao manejo dos fundos do Estado" e PÉREZ RoYo, Fernando. Derecho..., p. 368: "Este princípio da unidade é indispensável para assegurar o controle por parte do Parlamento."

${ }^{578}$ Manual..., p. 279. 
MANUEL DE JUANO ${ }^{579}$ adiciona também outras razões, porém, estas invocadas pelos governantes para justificar as constantes violações do referido princípio. Uma delas é oriunda do caráter empresarial que muitos serviços estatais possuem. Desta forma, com a unidade orçamentária, o interesse particular setorial de melhorar o serviço em específico é sobrepujado pelo interesse público, que demanda a satisfação igualitária de todos os serviços.

Outra razão é que em alguns países havia a tradição de se votar as despesas no orçamento e, por leis diversas, autorizavam as provisões para o custeio destes determinados gastos, promovendo o surgimento de orçamentos marginais e anexos, contas especiais ou mesmo orçamentos extraordinários (formas comuns de operacionalização da vinculação de receitas) ${ }^{580}$. Esta relativização é encontrada na doutrina francesa, ao relatar que essas três vertentes são as manobras comumente encontradas para flexibilizar as restrições oriundas da unidade orçamentária ${ }^{581}$.

HIPÓLITO ROSSY ${ }^{582}$ aponta isto como derrogação ao princípio, ao registrar que pode ser admitida a hipótese de orçamentos extraordinários ou suplementários em caso de transitoriedades que possam afetar o equilíbrio do orçamento principal. São encontrados, mormente, em épocas de dificuldades financeiras ${ }^{583}$. Por outro lado, GABRIEL FRANCO ${ }^{584}$ entende que os orçamentos extraordinários seriam na verdade uma violação do princípio da unidade, enquanto que os orçamentos especiais - que abrigariam contas de antecipação e créditos recuperáveis - são uma consequência da evolução do Estado Moderno.

Também é relevante registrar a ressalva de ALAIN BARRÈRE ${ }^{585}$ no sentido de que, assim como os demais princípios (universalidade e não afetação), não pode haver a concepção da unidade de forma inteiriça e absoluta - comportando exceções tais como os orçamentos anexos e as contas especiais do Tesouro. PIERRE JOUANIQUE ${ }^{586}$, por outro lado, chegou até a classificar as exceções ao princípio da unidade seguindo uma "ordem de

\footnotetext{
${ }^{579}$ Curso..., p. 388.

${ }^{580}$ Cf. JuANO, Manuel de. Curso..., p. 388. No Brasil, estes institutos são proibidos, conforme observado pelas regras do princípio da unidade - ora tratado - e da universalidade (ver item 3.5.2 infra). A instrumentalização das vinculações no Brasil dá-se, portanto, sobretudo por meio dos fundos orçamentários, que mitigam a não afetação (ver item 4.1 infra).

${ }_{581}$ Cf. TROTABAS, Louis; Finances..., p. 119.

${ }^{582}$ Instituciones de derecho financiero. Barcelona: Distribución Librería Bosch, 1959, p. 126.

${ }^{583}$ Cf. TROTABAS, Louis. Finances..., p. 119.

${ }^{584}$ Principios de hacienda pública. Madrid: Derecho Financiero, 1967, p. 105.

585 Institutions financières. 2. ed. t. I. Paris: Précis Dalloz, 1972, p. 176.

${ }^{586}$ Budget de l'état. Paris: Centre de Documentation Universitaire, 1947, p. 26. O restante da ordem é: orçamentos extraordinários, os cadernos coletivos de créditos suplementares, os orçamentos dos estabelecimentos autônomos, as participações do Estado nas sociedades de economia mista, as Contas especiais do Tesouro.
} 
gravidade", incluindo os orçamentos anexos como o primeiro instrumento que mais viola a unidade orçamentária, indo de encontro à opinião do primeiro jurista.

A crítica percuciente, sobretudo aos orçamentos extraordinários, é que se depreende uma falsa impressão de equilíbrio orçamentário ao se retirar determinadas despesas do orçamento geral e incluí-las no extraordinário; mas esta aparente vantagem é que vem fazendo com que a prática dos orçamentos extraordinários torne-se cada vez mais corrente $^{587}$. MARIO SAENZ ${ }^{588}$ adverte, ao mencionar o teor da mensagem do ex-presidente estadunidense Franklin Delano Roosevelt para o orçamento daquele país, que os orçamentos anexos não são sinônimos de independência; na realidade, seriam apenas partes do orçamento geral do Estado, o que pode ser vantajoso em caso de diversos entes ou repartições autônomas.

MARCEL MOYE ${ }^{589}$ ressalta que, em razão da multiplicidade de serviços estatais, a unidade apresenta-se como um dos princípios mais difíceis de serem efetivados na prática $^{590}$. Outro fator preponderante é que o seu desrespeito, comumente, é coligado a uma má-gestão estatal que, com vários orçamentos intrincados e obscuros, utilizam desta prática espúria para que a descoberta de eventuais déficits e irregularidades seja uma atividade ingrata à fiscalização estatal.

Portanto, pela impressão majoritária, o benefício de se ter uma segregação de verbas para uma gestão comercial ou mais eficiente de algum serviço é sobrepujado pela dificuldade de fiscalização e controle na aplicação destas verbas, o que pode ser usado para fundamentar a sua existência ou as excepcionalidades.

\subsubsection{PRINCÍPIO DA UNIDADE DE CAIXA}

Pela classificação de José JUAN FERREIRO LAPATZA ${ }^{591}$, é possível observar que o princípio da unidade aparece como gênese dos demais três grandes princípios orçamentários correlatos ao tema; ressalta o autor que este princípio abarca o princípio da unidade em sentido estrito, o princípio da universalidade, o princípio da unidade de caixa

\footnotetext{
${ }^{587}$ Cf. TROTABAS, Louis. Finances..., p. 120-21.

${ }^{588}$ Presupuesto nacional. Buenos Aires: Cuadernos Radicales, 19--, p. 22-23.

${ }^{589}$ Précis élémentaire de législation financière: a l'usage des étudiants des facultés de droit: Paris: Larose \& Forcel, 1905, p. 338.

590 Alberto DeOdAto (Manual..., p. 291-92) expressa, inclusive, que tal princípio, sob a égide de constituições anteriores a 1988 no Brasil, foi muito "sacrificado" por conta dos anexos, orçamentos e contas extraordinárias.

${ }^{591}$ Curso..., p. 312-17.
} 
e o princípio da não afetação. Diante desta moldura, o princípio da não afetação estaria mais ligado ao princípio da unidade de caixa, pois este último promoveria a viabilidade da existência da não afetação de receitas.

O princípio da unidade de caixa é bem definido por LOUIS TROTABAS ${ }^{592}$ :

Esta regra não proíbe a afetação de créditos, mas sim a afetação de dinheiro a uma despesa determinada. Ela obriga à contabilidade a ter somente um caixa, no qual são reunidos todos os fundos correspondentes aos seus diversos serviços. A contabilidade deve então prover a todas as despesas com os fundos dispostos, mesmo que eles tenham sido arrecadados sob o regime de afetação de receitas.

Embora a doutrina hispânica incline-se pela existência da regra da unidade de caixa como uma manifestação do princípio da unidade ${ }^{593}$, entendemos que, conceitualmente, há uma relação umbilical entre a unidade de caixa e o princípio da unidade, de forma que, neste trabalho, preferimos tratá-los como equivalentes ${ }^{594}$. É observável tal característica do conceito supramencionado, que expressa que ele não proíbe a afetação de créditos (receitas), mas de dinheiro, o que mostra a sua aproximação ao princípio da unidade e não afetação na sua faceta contábil.

JOSÉ JUAN FERREIRO LAPATZA ${ }^{595}$ sublinha inclusive, quanto ao ordenamento espanhol, que o princípio da unidade de caixa, juntamente com o princípio da não afetação, exige que os fundos de cada comunidade autônoma sejam destinados a cobrir as despesas da respectiva comunidade, sob pena de se solapar a própria autonomia destas unidades. Por esta razão é que há a diferenciação entre os fundos do Estado e os de cada uma das comunidades autônomas.

FERNANDO PÉREZ ROYO ${ }^{596}$ entende que a unidade de caixa estabelece a proibição de afetação de receitas públicas, incluindo um caractere importante ao princípio: a imposição de que haja a centralização da arrecadação estatal em um agente público, formando a regra da centralização das contas de receitas e despesas. Desta forma, conclui o jurista de Sevilha que o alcance da unidade de caixa é menor do que o princípio da unidade, de forma que concentra o conceito à pessoa jurídica "Estado" e aos órgãos

\footnotetext{
${ }^{592}$ Finances..., p. 146.

${ }^{593}$ Esta é a opinião, por exemplo, de FERnANDO PÉREZ RoYo (Derecho..., p. 370).

${ }^{594}$ Cf. Silva, Sebastião de Sant'Anna e. Os princípios..., p. 19-20. O autor explica que o princípio englobaria duas premissas básicas: unidade formal e unidade de caixa. Relata, ainda, que LEÓN SAY já condicionava a existência do princípio da unidade à regra do caixa único. Porém, foi ADOLPH WAGNER quem definiu que a regra contábil da unidade de caixa, por consequência, acarretaria o princípio da unidade orçamentária.

${ }^{595}$ Curso..., p. 317.

${ }^{596}$ Derecho..., p. 370.
} 
autônomos, não abarcando o conjunto do setor público estatal, donde se infere que aquele princípio é mera derivação deste.

Como solução prática e mais adequada ao ordenamento brasileiro, preferimos, deste modo, seguir a tradição doméstica de divisão tripartite (mas não estanque) entre princípio da unidade, princípio da não afetação e princípio da universalidade. O princípio da unidade de caixa é inserto obrigatoriamente, desta forma, dentro do princípio da unidade, tendo em consideração as similitudes conceituais existentes. E o princípio do orçamento bruto, que será tratado alhures ${ }^{597}$, no princípio da universalidade.

Aliás, é esta a conclusão de Horacio GuILLERMO CORTI ${ }^{598}$ ao mencionar que, dada a existência da universalidade e generalidade, é decorrência lógica que todos os recursos públicos ingressem em um caixa único. Daí adviria o princípio da não afetação, pois a regra geral seria que os recursos adentrem no caixa sem a afetação a um gasto em específico. Esta é uma derivação possível, contudo, não necessária, da conjugação destes princípios. Porém, ainda segundo o jurista platino, a não afetação é incindível com relação à regra da tesouraria única.

Esta concepção é forte no ordenamento argentino, tendo em vista que o artigo 80 da Ley $\mathrm{n}^{\circ}$ 24.156/92 consigna, expressamente, a unidade de caixa:

Art. 80. El órgano central de los sistemas de administración financiera instituirá un sistema de caja única o de fondo unificado, según lo estime conveniente, que le permita disponer de las existencias de caja de todas las jurisdicciones y entidades de la administración nacional, en el porcentaje que disponga el reglamento de la ley. (destacou-se)

Com o fundo único, na Argentina os gastos são individualizados e classificados, evitando-se, destarte, a pulverização em diversos fundos - entretanto, sem prejuízo da existência de fundos com afetações especiais, revogando-se a regra geral ${ }^{599}$.

\subsubsection{PRINCÍPIO DA UNIDADE NO DIREITO COMPARADO}

O princípio da unidade, apesar de preocupação vetusta, nem sempre foi observado nos países mais desenvolvidos. E nem todas as nações europeias conceberam a unidade orçamentária inicialmente: em algumas - como na Bélgica em 1884 - só surgiu após a

\footnotetext{
${ }^{597}$ Ver item 3.5.2.2 infra.

${ }^{598}$ Derecho constitucional..., p. 310-11.

${ }^{599}$ Cf. CORTI, HoraCIO GUILLERMO. Derecho constitucional..., p. 311-12.
} 
consolidação dos ideários franceses sobre o orçamento ${ }^{600}$. O apanhado comparativo de LELLO GANGEMI ${ }^{601}$ estampa que, no século passado, o princípio da unidade apareceu comumente nos países desenvolvidos:

(i) no Japão, as receitas e despesas aparecem em um só documento, subdivido em uma conta geral (receita e despesas concebidas na forma bruta) e conta especial (cuja concessão excepcional de certa autonomia permite a vinculação de receitas a uma despesa específica);

(ii) no Reino Unido, a unidade aparece como um princípio rígido. As contas especiais do Tesouro são medidas assaz restritas de exceção a esta regra.

(iii) na ex-União Soviética, o princípio era respeitado de forma absoluta, restando incólume diante do orçamento consolidado, que agregava os orçamentos das repúblicas juntamente com os das coletividades locais;

(iv) na Itália, não se olvidou da possibilidade de haver entes com autonomia contábil, porém, com cujos orçamentos coligados ao orçamento geral do Estado;

(v) na França, surge inscrito nos termos da ordonnance de 1959, reformulada pela nova loi organique relative aux lois de finances (LOLF) de 2001, com exceções que serão vistas algures com minúcias ${ }^{602}$; e

(vi) todavia, quanto à Alemanha, o autor não menciona a existência e positivação do princípio da unidade.

Na Itália, AChILle DonAto GiAnNINI ${ }^{603}$ menciona que o artigo 39 da Lei de Contabilidade do Estado (Regio Decreto 18 Novembre 1923, n. 2440, reformado pela Lei $\mathrm{n}^{\circ} 468$, de 5 de agosto de 1978), que previa o princípio da unidade orçamentária, vedava a assegnazione de qualquer provento a despesa específica. No mesmo dispositivo havia a previsão de exceções a esta regra em razão de entes da Administração que possuíam orçamento próprio $^{604}$.

\footnotetext{
${ }^{600}$ Cf. SAY, León. Dictionnaire..., p. 659.

${ }^{601}$ Sistemi finanziari comparati. t. I e II. Torino: Utet, 1967. Japão: t. II, p. 41; Reino Unido: t. II, p. 146; União Soviética: t. II, p. 600; Itália: t. I, p. 220. França: t. I, p. 379; Alemanha: t. I, p. 502.

${ }^{602}$ Ver item 3.6 infra.

${ }^{603}$ Elementi di diritto finanziario. Milano: Giuffrè, 1945, p. 307.

604 Art. 39. È vietata l'assegnazione di qualsiasi provento per spese od erogazioni speciali, rimanendo soppressa ogni destinazione già stabilita da particolari disposizioni.

Questa disposizione non si applica ai proventi e quote di proventi riscossi per conto di privati o enti estranei all'amministrazione dello stato, né ai proventi derivanti da lasciti, fondazioni, oblazioni e simili, fatte a scopo determinato.
} 
A Constituição da Guatemala prevê a obrigatoriedade do princípio da unidade de forma ferrenha (artigo 237), porém, com relativizações no tocante ao orçamento das entidades descentralizadas administrativamente, em consagração à logicidade do sistema orçamentário. Na Constituição panamenha, há a previsão do princípio da unidade em seu artigo $265^{605}$ de forma mais completa do que ocorre em outros ordenamentos, incluindo os orçamentos das entidades da Administração Indireta.

A Constituição da Espanha, por exemplo, prevê, em seu artigo 134, item 2, primeira parte, que deve ser incluído no orçamento geral a totalidade ${ }^{606}$ de gastos, constituindo verdadeira homenagem à unidade orçamentária:

Los Presupuestos Generales del Estado tendrán carácter anual, incluirán la totalidad de los gastos e ingresos del sector público estatal y en ellos se consignará el importe de los beneficios fiscales que afecten a los tributos del Estado. (destacou-se)

A segunda parte, segundo nossa opinião, consistiria em aspecto do princípio da universalidade, pois declara que os benefícios fiscais deverão estar expressamente albergados no orçamento geral, de forma a impedir que haja omissões quanto às renúncias de receita.

De forma menos concludente, mas como consequência lógica do princípio da unidade, a Constituição da Romênia, em seu artigo 138, estabelece que o orçamento geral deve compreender o Orçamento do Estado, o Orçamento da Seguridade Social e os Orçamentos dos entes locais.

A União Europeia, malgrado tradicionalmente seguir o direito positivo romanogermânico, preferiu a tradição dos países anglo-saxões, tais como os Estados Unidos e a Inglaterra $^{607}$, em considerar a unidade orçamentária como um princípio implícito. $\mathrm{O}$ professor espanhol RAMÓN FALCÓN Y TELLA ${ }^{608}$ expõe que tal princípio não é mencionado no orçamento da União Europeia, aparecendo apenas no artigo 3.1 do Regulamento Financeiro de 1977 - “o conjunto dos ingressos cobrirá o conjunto dos gastos” - e no

\footnotetext{
${ }^{605}$ Artículo 265. El presupuesto tendrá carácter anual y contendrá la totalidad de las inversiones, ingresos y egresos del sector público, que incluye las entidades autónomas, semiautónomas y empresas estatales.

${ }^{606}$ Concebendo-se, ad hoc, o princípio da unidade como o princípio da totalidade orçamentária, conforme exposto por SEBASTIÃo DE SANT'ANNA E SILVA (Os princípios..., p. 22), que vai além da mera concepção de documentação uniforme. JAMES GIACOMONI (Orçamento..., p. 65), nesta esteira, entende que o princípio da totalidade permite a coexistência de vários orçamentos, desde que consolidados em uma visão governamental conjunta. Por ser uma mera questão terminológica, adotaremos os dois princípios conjuntamente, até porque o princípio da unidade, modernamente, é concebido na forma exposta pelos autores.

${ }^{607}$ Cf. LAufenburger, Henry. Finances comparées. 2. ed. Paris: Recueil Sirey, 1950, p. 55-57. Um dos poucos casos de afetação de recursos que se pode extrair dos ordenamentos anglo-saxões, segundo o autor, é no caso de afetação para despesas de investimento, ocorridas, mormente, no período pós-guerra, demonstrando um caráter excepcional de relativização destes princípios orçamentários.

${ }^{608}$ Introducción..., p. 355.
} 
artigo 4.1 da Decisão de 7 de maio de 1985 (85/257/CEE, The European Atomic Energy Community - Euratom), estabelecendo que os recursos serão utilizados de forma indistinta para todos os gastos incluídos no orçamento das comunidades. Porém, no nosso entender, tais características seriam mais afetas ao princípio da universalidade ${ }^{609}$.

Diferentemente, no Brasil, tal princípio precisou estar expresso na Constituição, conforme ressalta PONTES DE MIRANDA ${ }^{610}$ quando houve a exclusão do orçamento corrente e do orçamento de capital na Constituição de 1967, definindo a unidade pela consagração do orçamento anual.

\subsubsection{CONCEPÇÃO MODERNA DO PRINCÍPIO DA UNIDADE}

JOSÉ MAURICIO CONTI ${ }^{611}$ demonstra que com a adoção positivada do princípio da unidade no artigo $2^{\circ}$ da Lei $n^{\circ} 4.320 / 64$, houve a sua releitura para uma concepção mais moderna e que se coadunasse com a técnica do orçamento-programa, que prescindia de uma unidade documental, mas perseguia uma unidade de desígnios na atividade governamental.

Assim, a doutrina nacional entende, atualmente, que o princípio da unidade ou totalidade faz com que todas as despesas e receitas do governo sejam registradas na lei orçamentária, que deve ser unida, compondo-se pelos orçamentos fiscal, de investimentos e da seguridade social $^{612}$.

Resta abandonado, portanto, o conceito de que o princípio da unidade deve conglobar as receitas e despesas em um documento único: o que deve ocorrer é a ligação entre despesa e receita em uma lógica orçamentária que, no Brasil, dá-se via leis orçamentárias. JACOB WILNER SUNDELSON ${ }^{613}$ já advertia que a questão da forma física do documento orçamentário não é tratada sob este princípio, visto que ele tende, na realidade, a evitar orçamentos menores, extraordinários, de capital, anexos, emergenciais, especiais ou industriais.

\footnotetext{
${ }^{609}$ Ver item 3.5.2 infra.

${ }^{610}$ Comentários..., p. 206.

${ }^{611}$ Direito..., p. 86-87.

${ }^{612}$ Cf. NASCIMEnTo, Carlos Valder. Curso de direito financeiro. Rio de Janeiro: Forense, 1999, p. 70-73 e GiaCOMONI, James. Orçamento..., p. 66-67.

${ }^{613}$ Budgetary..., p. 247.
} 
Hubert Brochier e PIERRE TABATONI ${ }^{614}$ mencionam interessante exemplo na Inglaterra, sendo comum a prática de dois orçamentos: o por cima da linha e o por debaixo da linha: o excedente do primeiro serviria, sobretudo, para cobrir o déficit do segundo este último seria como um orçamento extraordinário, com elementos de orçamento de capital. Ainda sobre os países anglófonos, faz-se oportuna a menção de ALBERTo DEODATO $^{615}$ acerca do performance budget surgido no Bureau of Budget estadunidense. Com esta concepção de orçamento, os Estados Unidos focavam no custo, por unidade, do serviço em questão, de forma globalizada.

Esta seria a tendência da doutrina mais moderna, ao afirmar que deve se admitir o desdobramento do orçamento em vários documentos, de modo que cada um trate relativamente de um tema específico no tocante à receita e despesa pública. A própria pluralidade de leis orçamentárias diferidas no tempo (plano plurianual, lei de diretrizes orçamentárias e lei orçamentária anual) veio a confirmar esta concepção mais atual do princípio da unidade no Brasil. O importante é que a noção de todo e a unidade de desígnios continuem, independentemente do aspecto formal de constar ou não em um documento único ${ }^{616}$.

Destarte, a doutrina entende que a suplência dos orçamentos múltiplos ${ }^{617}$ e independentes sobre a técnica do orçamento único é um mito de uma doutrina intervencionista estatal dita "moderna", cujo escopo é rechaçar os princípios clássicos orçamentários, dentre eles o da unidade e não afetação de receitas ${ }^{618}$. GILBERTO BERCOVICI $^{619}$, neste diapasão, explica que o fato de as contas orçamentárias serem únicas (tanto documentais como em caixa) evita as vinculações de receitas.

Ressalve-se que ARTHUR EUGENE BUCK ${ }^{620}$ apregoa a possibilidade de existência da multiplicidade orçamentária juntamente com o princípio da unidade orçamentária, tendo em vista a experiência dos orçamentos duplos (de despesas correntes e de capital) das municipalidades estadunidenses e soviéticas, que apresentavam os orçamentos de despesas correntes e os de despesas de capital de forma conjunta.

\footnotetext{
${ }^{614}$ Économie financière. Paris: Presses universitaires de France, 1959, p. 522.

${ }^{615}$ Manual..., p. 297.

${ }^{616}$ Cf. ConTi, José Mauricio. A autonomia..., p. 63.

${ }^{617}$ No Brasil houve a adoção de orçamentos múltiplos no âmbito federal na década de oitenta do século passado, com os orçamentos fiscal, monetário e das estatais. Cf. GIACOMONI, James. Orçamento..., p. 65.

${ }^{618}$ Cf. VILlegas, Hector Belisario. Curso..., p. 139.

${ }^{619}$ Os princípios orçamentários e a primeira Constituição Republicana. Revista de Direito Internacional e Econômico Porto Alegre. n. 3. abr./jun. 2003, p. 81.

${ }^{620}$ Apud Juano, Manuel de. Curso..., p. 384-85.
} 
Por derradeiro, saliente-se que o maior inconveniente dos orçamentos múltiplos, apontado por MANUEL DE JUANO ${ }^{621}$, é que a grande parte dos parlamentares não logra perscrutar efetivamente as diversas contas complexas, pela exigência de conhecimentos técnicos que dificultam esta análise orçamentária.

Diante disto, pode-se sintetizar que o princípio da unidade congrega todas as receitas e despesas sob um liame lógico-orçamentário, mantendo uma unidade de desígnios na atividade orçamentária estatal.

\subsubsection{PRINCÍPIO DA UNIVERSALIDADE ORÇAMENTÁRIA E SEU RELACIONAMENTO COM A NÃO AFETAÇÃO}

A doutrina italiana já mencionava que de nada adianta aparecer ao povo somente o que o Estado aufere de forma líquida, mas também o que os indivíduos contribuem ${ }^{622}$. Portanto, se o princípio da unidade - juntamente com o da não afetação - é aclamado pela doutrina como princípio contábil, o princípio da universalidade ${ }^{623}$ seria a faceta política do orçamento:

Os princípios políticos constituem um conjunto de regras com as quais se pretende substanciar o caráter básico necessário ao ordenamento como instrumento de equilíbrio de poderes e de distribuição de competências correspondentes a um Estado constitucional $^{624}$.

${ }^{621}$ Curso..., p. 385.

${ }^{622}$ Cf. NITTI, Francesco Saverio. Princípios da ciência das finanças. 2. v. Trad. de C. MACHADO. Rio de Janeiro: Atena, 1937, p. 330. O exemplo do autor é esclarecedor: "Se o monopólio que produz 200 milhões provoca despesas de 20 milhões, êsses dois numeros devem ser mencionados; o primeiro na receita, o segundo na despesa: e não somente a renda líquida de 170 milhões."

${ }^{623}$ Quanto à nomenclatura universalidade, convém ressaltar a classificação de ALBERTO DE STEFANI (Manuale di finanza. Bologna: Nicola Zanichelli, 1943, p. 84) quanto à lei orçamentária. Para o autor, ela obedeceria ao princípio da anualidade, universalidade e integridade. Porém, ao conceituar os princípios, no tocante à universalidade explica: “(...) porque todas, sem exceção, as somas que o Estado tem direito de perceber ou obrigação de pagar devem ser inseridas no orçamento". Já quanto ao conceito de integridade (integrità), ressalta que “(...) porque todas as entradas e todas as depesas do Estado devem estar compreendidas no orçamento pelo bruto, sem dedução por despesa de arrecadação, no tocante às entradas, ou por proventos especiais no tocante às despesas." Neste caso, o conceito coadunar-se-ia com o de universalidade, de forma que se poderia entender o termo integralidade como um sinônimo de universalidade. Por vezes, é possível encontrá-lo também sob o cognome de generalidade, como, v. g., apontado por HIPÓlITO ROSSY (Instituciones..., p. 125). O autor igualmente relativiza este princípio, possibilitando que algumas despesas possam ficar de fora da peça orçamentária, desde que imprevisíveis. HORACIO CORTI (Derecho..., p. 310) traz a universalidade e generalidade conjugados da seguinte forma: a universalidade estaria relacionada com a necessidade de que o orçamento contenha a totalidade dos ingressos; já a generalidade faz com que seja autorizada esta totalidade do gasto público.

${ }^{624}$ Cf. VillareJo, Avelino García; SANCHEZ, Javier Salinas. Manual..., p. 175 e 176. 
Segundo Helio SAUl MiLESKI ${ }^{625}$, pelo princípio da universalidade “(...) deve ser entendida a obrigação de constar do orçamento todas as receitas e todas as despesas do Poder Público, pelos seus totais, sem dedução de qualquer natureza." Salutar também é a lição de GIOVANNI INGROSSO ${ }^{626}$ de que o princípio impede a subtração de fatos financeiros do juízo preventivo e sucessivo do Parlamento; devem, destarte, “(...) entrar no procedimento orçamentário reconhecido"627.

Três eram as razões do Parlamento na adoção do princípio: (i) conhecer as despesas e receitas a priori; impedir o Poder Executivo de atuar com as receitas e despesas sem a prévia autorização do Legislativo; e conhecer o volume das despesas, em sua forma global, a fim de que o Legislativo fixe a exata carga tributária de maneira a não haver excesso ou deficiência nesta imposição ${ }^{628}$.

PiERre JouAnique ${ }^{629}$ demonstra que a lei francesa das finanças públicas de 15 de maio de 1818 previu a existência do conceito de produto bruto e que as despesas também devem figurar juntamente com a receita, o que, juntamente com a ordonnance de 1817 que proibia que as despesas fossem "mascaradas" por detrás das receitas -, fez construir o conceito de universalidade. Para o jurista REnÉ STOURM ${ }^{630}$, a lei de 1818 surgiu com o escopo de evitar os abusos que se passavam na França até a sua edição.

Mas, na verdade, somente com o decreto de 1862 é que o conceito apareceu da forma como o encontramos atualmente, tendo em vista que a ordonnance, em seu bojo, permitia que, inversamente, uma receita pudesse ser vinculada a uma despesa ${ }^{631}$. Menciona RENÉ STOURM ${ }^{632}$ que a contrapartida às normas de 1817 e 1818 - ou seja, a proibição de se “mascarar" uma receita atrás de uma despesa - veio com a ordonnance de 14 de setembro de 1822, destacando sua importância no ordenamento orçamentário.

O princípio da universalidade, todavia, é preocupação vetusta. Seu núcleo conceitual já era objeto de discussão na Inglaterra em 1630 pelo economista THOMAS MUN, segundo EDUARdo MARCIAL FERREIRA JARDiM ${ }^{633}$. E também o ex-primeiro ministro italiano FRANCESCO SAVERIO NITTI ${ }^{634}$ expressava que não haveria nada mais maléfico em

\footnotetext{
${ }^{625}$ O controle..., p. 51.

${ }^{626}$ Corso di finanza pubblica. Napoli: Jovene, 1969, p. 639.

${ }^{627}$ Cf. SundELSON, Jacob Wilner. Budgetary..., p. 243.

${ }^{628}$ Cf. Silva, Sebastião de Sant'anna e. Os princípios..., p. 14.

${ }^{629}$ Budget..., p. 24.

${ }^{630}$ Le budget..., p. 128 e ss, especialmente 133-34.

${ }^{631}$ Cf. JouAniQue, Pierre. Budget..., p. 24.

${ }^{632}$ Le budget..., p. 135.

${ }^{633}$ Manual de direito financeiro e tributário. 2. ed. São Paulo: Saraiva, 1994, p. 24.

${ }^{634}$ Princípios..., p. 331.
} 
matéria de finanças públicas do que o mistério, recitando que, nos termos da moral kantiana, o que não pode ser manifestado não é honesto. Desta forma, isso seria um indicativo de que nem tudo funciona regularmente. A universalidade erigiu-se, nesta concepção, como um dos princípios mais importantes - sobretudo no Brasil ${ }^{635}$.

DINO JARACH ${ }^{636}$ e GUILLERMO AHUMADA ${ }^{637}$ entendem que a universalidade é corrompida pela afetação de despesas, por ser um isolamento da atividade estatal; na mesma esteira, ARIOSTO DE REZENDE ROCHA ${ }^{638}$ - seguindo os escólios de HARLEY LEIST LUTZ - demonstra que a afetação de receitas transgride o princípio da universalidade, ressalvando, no entanto, haver controvérsias quanto a esta violação: existindo a devida referência no orçamento quanto às receitas vinculadas - e, quanto às despesas, a dotação necessária para a sua satisfação -, não haveria a quebra do princípio em comento.

MAURICE DUVERGER ${ }^{639}$, assim, diferencia o princípio da universalidade e o da não afetação:

A universalidade consiste em inscrever separadamente no orçamento todas as despesas e todas as receitas sem haver compensação entre elas; o princípio da não afetação proíbe que determinadas receitas sirvam a cobrir determinadas despesas, estando umas e outras, aliás, inscritas no orçamento. A universalidade impede as compensações contábeis; a não afetação proíbe as ligações jurídicas entre receitas e despesas.

Esta discriminação do professor francês, além de elucidativa, transmite a característica essencial existente entre o princípio da universalidade e da não afetação em nossa opinião, de forma que este possa ser considerado um desdobramento daquele ao vedar as ligações jurídicas entre receitas e despesas. E, para o autor ${ }^{640}$, toda violação à universalidade é uma violação ao princípio da não afetação, mas a recíproca não é verdadeira, ainda que as exceções à não vinculação tendam a crescer com o passar dos $\operatorname{anos}^{641}$.

\footnotetext{
${ }^{635}$ Cf. TORRES, Ricardo Lobo. Tratado..., p. 333.

${ }^{636}$ Finanzas..., p. 82. Expressa ser imperioso "que não haja afetação direta de um ou mais recursos para cobrir certos gastos. Sem prejuízo dos inconvenientes que pode acarretar esta afetação quando os recursos forem insuficientes para cobrir os gastos em questão ou forem excessivos, a afetação significa um isolamento de uma atividade do Estado e sua subtração do cálculo econômico da atividade financeira em seu conjunto."

${ }^{637}$ Tratado..., p. 746. O autor ressalta, inclusive, que esta criação de gastos privilegiados viola a teoria do gasto público, “(...) já que as necessidades a serem satisfeitas, uma vez eleitas, devem ser consideradas em um plano de igualdade e a dotação do montante do recurso deve estar relacionada com o grau, extensão e imperiosidade da necessidade a se satisfazer, grau que se estabelece na distribuição orçamentária total, sem exceções, que criam privilégios de controle difícil."

${ }^{638}$ Rendas..., p. 38.

${ }^{639}$ Finances..., p. 320.

${ }^{640}$ Cf. DUVERGER, Maurice. Finances..., p. 321.

${ }^{641}$ Cf. CARTOU, Louis. Droit financier et fiscal européen. Paris: Dalloz, 1972, p. 27. Esta estreita ligação jurídica também é verificada por este autor.
} 
Assim, igualmente à unidade, a não afetação costuma ser vista pela doutrina apesar de não pacificamente - como uma transgressão à universalidade orçamentária. Neste ponto pensamos, no entanto, de forma diversa: não é toda transgressão à universalidade que violará também a não afetação. Ou seja, a inscrição da receita líquida no orçamento geral não significa que houve uma vinculação indevida; pode, por exemplo, ter havido o desvio de recursos ou a malversação no seu uso.

\subsubsection{FUNDAMENTOS E EXCEÇÕES À UNIVERSALIDADE}

O jurista argentino MANUEL DE JUANO ${ }^{642}$, sob um sistema de premissas financeiras, chega à conclusão das razões de existência do princípio da universalidade no seguinte silogismo:

\footnotetext{
$1^{\circ}$ Ao se preparar o orçamento, deve-se fazer figurar neste documento todas as previsões sobre os recursos correspondentes;

$2^{\circ}$ Durante o período da execução orçamentária, os recursos efetivamente percebidos devem estar à disposição do Tesouro nos caixas do Tesouro e não se poderá ordenar nenhum outro gasto sobre esse crédito orçamentário, e somente até o limite de recurso previsto.

Conforme o exposto, afirma-se que a universalidade orçamentária consiste em que todos os recursos e todos os gastos, sem exceção, figurem no orçamento.
}

Sob este roteiro, visa-se a evitar que haja os famosos caixas negros, ínsitos às gestões financeiras às escondidas, cujo escopo precípuo é o de solapar o controle orçamentário $^{643}$. Percebe-se, também desta ilação, que o princípio da universalidade deve respeitar os procedimentos orçamentários de determinada nação ${ }^{644}$.

Esse é um dos postulados mais relevantes de sua existência, que desponta, conforme explica MARCEL MOYE ${ }^{645}$, como único meio a garantir a verdade orçamentária, evitando eventuais confusões ou alterações orçamentárias. É a partir dele que se verifica a real situação financeira de um Estado: equilibrada, deficitária ou superavitária.

\footnotetext{
${ }^{642}$ Curso..., p. 382. Grifos do original.

${ }^{643}$ Cf. JuAno, Manuel de. Curso..., p. 382.

${ }^{644}$ Cf. Ellwood, John W.; Sprague, Mary. Options for Reforming the California State Budget Process. [s.l.]: [s.n.], 19--, p. 342. Disponível em: http://igs.berkeley.edu/library/htConstReform2003ELLWOODtext.pdf. Acesso em: 28 fev. 2009. Denominado em inglês como comprehensiveness, os autores explicam que "(...) faz-se mister que todos os gastos e receitas governamentais estejam sujeitos ao mecanismo do orçamento e entrem no reconhecido procedimento orçamentário.”

${ }^{645}$ Précis..., p. 336.
} 
O caráter verídico, no entender de FRANCESCO SAVERIO NitTI ${ }^{646}$, estaria intimamente associado à publicidade, uma vez que não pode haver segredos orçamentários, mesmo em tempos difíceis para a nação. Consoante o autor, impera a máxima de que a verdade, ainda que dura e árdua, vale mais que a ficção. A veracidade do orçamento como corolário do princípio da universalidade também é destacada por HECTOR BELISARIO VILLEGAS ${ }^{647}$, pois as compensações de receitas e despesas podem induzir a erro os órgãos de controle externo, como os Tribunais de Contas, ao incluir gastos inferiores aos reais.

Além da veracidade, é importante ressaltar que a doutrina também aponta a clareza $^{648}$ como característica deste princípio, o que acarretará a fidelidade da peça orçamentária em comparação ao status quo financeiro do Estado ${ }^{649}$. Para o mestre francês RENÉ STOURM ${ }^{650}$, "a clareza quer dizer a luz indispensável a quem quer que queira gerenciar, controlar, ou somente estudar as finanças públicas.” De acordo com o autor, daí é que se pode concluir a situação orçamentária de uma nação: equilibrada, excedente de receitas (superavitária) ou deficitária.

A doutrina nacional também abarca esta função no ordenamento constitucional. RICARDO LOBO TORRES ${ }^{651}$ entende, e. $g$., que a clareza, que veio para evitar as práticas orçamentárias encobertas, restou consagrada pelo constituinte de 1988 no Brasil mormente pelos artigos 70 e $165, \S 6^{\circ}$ da Carta Magna.

RENÉ STOURM ${ }^{652}$ aponta que os méritos do princípio da universalidade podem ser reduzidos a duas palavras. Uma é a própria clareza já apontada; a outra seria a economia. Esta última porque "a prudência aconselha que se evite colocar as despesas muito perto das receitas correlatas." Há a vantagem de se impedir a influência econômica no orçamento, dado que o legislador não poderá, politicamente, avaliar cada crédito apenas sob uma necessidade isolada, mas sim considerando o conjunto das receitas e despesas.

\footnotetext{
${ }^{646}$ Princípios..., p. 329.

${ }^{647}$ Curso..., p. 130.

${ }^{648}$ A clareza é tratada por JACOB WILNER SUNDELSON (Budgetary..., p. 258) como princípio autônomo. Segundo o jurista, "nenhum sistema orçamentário pode satisfazer quaisquer de suas funções a menos que estipule uma apresentação inteligível e não deixe margem para dúvidas ou escolha na mente daqueles que leem ou são guiados pelo orçamento."

649 Cf. Martins, Cláudio. Compêndio de finanças públicas. São Paulo, Bushatsky, 1976, p. 224 e NASCimento, Carlos Valder do. Curso..., p. 73.

${ }^{650}$ Le budget..., p. 150.

${ }^{651}$ Tratado..., p. 319.

${ }^{652}$ Le budget..., p. 149-50.
} 
MANUEL DE JUANO ${ }^{653}$ entende que, em situações extremas, a derrogação do princípio da universalidade pode ser útil, levando em conta que uma eventual afetação de receitas infirmando a universalidade poderá atender melhor e mais firmemente às exigências de um determinado tempo e lugar. Contudo, propugna o jurista por uma posição mais ponderada nestas derrogações, ao destacar que:

Agregaremos que ao colocar os olhos nos recursos, a autoridade orçamentária não deve e nem pode confiar demasiadamente, nem muito pouco, na sua exuberância ou nos seus rendimentos, dado que isso tem incidência na economia de um país. A prudência aconselha atuar com um critério eclético na emergência. (destaques do original)

Logo, diante desta vertente, os benefícios da universalidade não seriam incontestes, comportando exceções ao princípio. JULIEN LAFERRIÈRE e MARCEL WALINE $^{654}$, por exemplo, ao desferirem críticas percucientes ao princípio da universalidade, encontram os mesmos óbices ou vantagens que a doutrina aponta no tradeoff da afetação de receitas, quais sejam:

a) A regra da universalidade pode conduzir a situações grotescas: a madeira extraída do bosque de Versailles, por exemplo, não poderia ser utilizada para o aquecimento das construções de seu perímetro, mas sim vendidas para serem recompradas e posteriormente utilizadas junto com outros combustíveis;

b) A universalidade não estimula a iniciativa e a eficiência administrativa, visto que o aumento de receita será consumido pelo abismo sem fundo do orçamento geral, sem que retorne ao serviço que a gerou;

c) Por fim, conforme já mencionado, a regra é incompatível com uma gestão comercial dos serviços e de autofinanciamento que as empresas devem possuir este é um dos casos apontados por GABRIEL FRANCO ${ }^{655}$ como exceção necessária ao princípio, "sob pena de complicar extraordinariamente a contabilidade pública". No caso, as maiores empresas estatais francesas possuíam esta característica comercial prevista pelas leis orgânicas, livres da regra da universalidade.

\footnotetext{
${ }^{653}$ Curso..., p. 378.

${ }^{654}$ Traité..., p. 93-94.

${ }^{655}$ Principios..., p. 104.
} 
Concordamos com a última observação. Conforme visto ${ }^{656}$, o princípio da unidade excepciona os demais entes da Administração Indireta, podendo antever orçamentos próprios. Aqui, a universalidade permite a autogestão destas empresas. Porém, isso não exime estas entidades de que constem as verbas nas prestações de contas ao ente federativo respectivo.

\subsubsection{PRINCÍPIO DO ORÇAMENTO BRUTO}

A regra da universalidade - lembra ESTEBAN JARAMILLO ${ }^{657}$ - é amplamente difundida nos ordenamentos modernos, citando o exemplo do orçamento inglês que prevê esta separação dos gastos e receitas de forma evidente, trazendo, como consequência, a regra do orçamento bruto. Um exemplo desta regra no Brasil é dado por JAMES GIACOMONI $^{658}$ com relação ao imposto de renda retido pelos Estados e Municípios sobre a remuneração de seu respectivo pessoal. Apesar disso, o princípio do orçamento bruto tem como pressuposto “(...) fazer aparecer no orçamento federal as estimativas do total das retenções a serem feitas pelos Estados e Municípios, e, na despesa, o mesmo montante como transferência a essas entidades". Segundo o autor, tal princípio só começou a ser observado a partir do orçamento de 1981.

CARLOS GIULIANI FONROUGE ${ }^{659}$ também ressalta a característica de produto bruto que consagra o princípio da universalidade, fazendo com que os recursos sejam inscritos no orçamento na íntegra, sem descontos ou deduções; porém, o autor argentino adverte que há estudiosos, como JESSE BURKHEAD, que utilizam esta conceituação para o princípio da universalidade, contudo, não sendo acolhida pelos doutrinadores europeus.

JACOB WILNER SUNDELSON ${ }^{660}$, ao analisar o princípio da universalidade, entende que não pode haver a consagração deste princípio sem a observância da concepção bruta do orçamento. Desta forma, demonstra que, inclusive, alguns doutrinadores consideram tal corolário de suma importância que deve ser destacado como um princípio à parte.

A regra do orçamento bruto teria aparecido juntamente com o princípio da universalidade, visando a resguardar os mesmos escopos e vedando a técnica de

\footnotetext{
${ }^{656}$ Ver item 3.5.1 supra.

${ }^{657}$ Tratado..., p. 567.

${ }^{658}$ Orçamento..., p. 73.

${ }^{659}$ Derecho..., v. I, p. 169.

${ }^{660}$ Budgetary..., p. 245. A doutrina mencionada pelo autor é referente aos escritos de KAREL ENGLIS.
} 
transcrição líquida do orçamento. Diante disto, JAMES GIACOMONI ${ }^{661}$ entende que o “(...) princípio do orçamento bruto deve ser analisado no âmbito do orçamento geral do governo", consoante prescreve o artigo $6^{\circ}$ da Lei no 4.320/64, guardando tal conceituação uma proximidade com o conceito de universalidade já exposto.

$\mathrm{O}$ produto bruto seria, portanto, o elemento definidor do princípio da universalidade, diferenciando-o do princípio da unidade. OSCAR JosÉ DE PLÁCIDO E SILVA ${ }^{662}$, por exemplo, trata a regra do orçamento bruto como decorrência lógica do princípio da universalidade. E JACOB WILNER SUNDELSON ${ }^{663}$, inclusive, critica FRANCESCO SAVERIO NITTI ao considerar a regra do orçamento bruto com a da unidade orçamentária.

Merece menção que outra parte da doutrina entende que o princípio do orçamento bruto é englobado pelo princípio da universalidade por ser a sua faceta contábil, ao permitir a avaliação real das receitas e dos custos dos serviços a fim de se autorizar a execução de um gasto ${ }^{664}$. Pensamos que da mesma forma que a unidade de caixa possui relação umbilical com a unidade, o mesmo fato é verificado no caso do orçamento bruto e universalidade. Assim, ambos devem ser considerados como princípios complementares.

Por fim, SEBASTIÃo DE SANT'ANNA E SILVA ${ }^{665}$ resgata, ainda, que a doutrina mais moderna vem tentando imprimir nova significação à regra do orçamento bruto, dada a sua incompatibilidade na gestão comercial e industrial estatal - atividade esta em franca expansão por meio das empresas estatais e outros entes da Administração Indireta. Estas atividades, por decorrência lógica, só poderiam entrar no orçamento geral mediante o resultado líquido, sendo este, na verdade, o escopo perseguido pelo Parlamento: conhecer o resultado destes entes descentralizados. JACOB WILNER SUNDELSON ${ }^{666}$ destaca, neste contexto, a dificuldade de se encontrar orçamentos que não infrinjam esta regra.

\subsubsection{PRINCÍPIO DA UNIVERSALIDADE NO DIREITO COMPARADO}

A gênese da universalidade é comumente identificada com o sistema orçamentário inglês. Inicialmente, os tributos eram criados para serem vinculados a um escopo único;

\footnotetext{
${ }^{661}$ Orçamento..., p. 72.

${ }^{662}$ Vocabulário..., p. $50-51$.

${ }^{663}$ Budgetary..., p. 245, nt. 23.

${ }^{664}$ Cf. JUANO, MANUEL de. Curso..., p. 371. Ver, porém, item 3.5.1 supra e opiniões de RAMÓN FALCÓN Y TElla, AVElino García Villarejo e JaVIER SALINAS SANCHEZ, e Nico GROENENDIJK.

665 Os princípios..., p. 13 e 15-17.

${ }^{666}$ Budgetary..., p. 245.
} 
todavia, com o passar do tempo - e a evolução na arrecadação e gasto -, o balanceamento desta contabilidade foi tornando-se complicado, redundando na necessidade de se criar um fundo consolidado $^{667}$, com todas as receitas tributárias, bem como as respectivas despesas estatais. Foi então que, com o Consolidated Fund Act, abrangeu-se a totalidade de receitas e despesas do governo britânico, a fim de se registrar as despesas do Estado e inscrever os impostos criados para suprir as finalidades assinaladas no fundo ${ }^{668}$.

Sobre o tema, pondera FrANCESCO SAVERIO NITTI ${ }^{669}$ que ao Fundo Consolidado faltar-lhe-ia importância prática em alguns casos, tendo em vista a natural liberdade do Parlamento em tomar suas decisões. Desta forma, na hipótese de querelas deste Poder com o Executivo, o fundo não teria nenhuma influência nessa questão, já que ele foi criado para limitar os poderes da Coroa, e não do Parlamento.

Além do sistema inglês, RENÉ STOURM ${ }^{670}$ cita que outros países também adotam a universalidade, tais como a Rússia, Bélgica, a antiga Prússia e a já mencionada Inglaterra esta última, segundo o autor, desde 1848. Em extenso estudo comparativo, LELLO GANGEMI $^{671}$ também adiciona que o princípio aparece:

(i) no Japão, obrigando o cômputo do montante bruto das entradas e das despesas públicas;

(ii) nos Estados Unidos, cujas despesas são submetidas à aprovação do Legislativo, mesmo nos casos de execução pelos entes autônomos que não aparecem no budget central - ocasião em que serão aprovadas pela Câmara local; (iii) na ex-União Soviética, onde o princípio era deveras relativizado. O conjunto de entradas e despesas não aparecia in totum no orçamento, mormente no caso dos fundos de receitas destinados a empresas públicas, donde se escapava da influência da autoridade central;

(iv) na Itália, com as despesas e receitas inscritas no bilancio de forma bruta;

(v) na França, nos termos da ordonnance de 1959, reformulada pela LOLF,

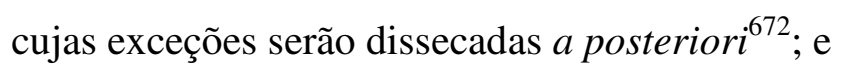

\footnotetext{
${ }^{667}$ JAMES GIACOMONI (Orçamento..., p. 64), todavia, relaciona o surgimento do Fundo Consolidado com a consagração do princípio da unidade.

${ }^{668}$ Cf. CONTI, José Mauricio. A autonomia..., p. 57.

${ }^{669}$ Princípios..., p. 340.

${ }^{670}$ Le budget..., p. 145-49.

${ }^{671}$ Sistemi..., Japão: t. II, p. 41; Estados Unidos: t. II, p. 277; União Soviética: t. II, p. 600; Itália: t. I, p. 219 20; França: t. I, p. 379; Alemanha: t. I, p. 502.

${ }^{672}$ Ver item 3.6 infra.
} 
(vi) na Alemanha, havendo inclusive afirmação constitucional no artigo 110, com algumas peculiaridades quanto às estatais ${ }^{673}$.

A Constituição da Grécia também prevê a universalidade em seu artigo 79, item 2, já que todas as receitas e gastos devem estar incluídos no orçamento anual, abarcando tacitamente o princípio da unidade ao prever a sua inscrição em um orçamento único. Igualmente, cumpre registrar que a universalidade é inscrita na Constituição do Panamá em seu artigo $274^{674}$, além de prever o princípio da unidade.

O princípio da universalidade aparece da mesma maneira na Argentina, no artigo $2^{\circ}$ da Lei 24.156/1992. Indica a doutrina que a sua positivação na nação platina não só proíbe as compensações, mas também exige dados dos resultados obtidos pelo poder público, bem como a demonstração de correspondência da aplicação em bens e serviços com o prometido. Surge, portanto, em uma concepção muito mais holística que a usual, pois congrega conceitualmente o princípio da transparência ${ }^{675}$.

\subsubsection{CONCEPÇÃO ATUAL DO PRINCÍPIO DA UNIVERSALIDADE}

ARIOSTO DE REZENDE ROCHA ${ }^{676}$ explica que é um equívoco equiparar o princípio da universalidade com o da unidade, sendo institutos diversos, da mesma forma que a especialização é diferente da multiplicidade orçamentária. Convém apenas mencionar que esta última característica, muito debatida na França no século XIX - conforme expõe

673 (1) Alle Einnahmen und Ausgaben des Bundes sind in den Haushaltsplan einzustellen; bei Bundesbetrieben und bei Sondervermögen brauchen nur die Zuführungen oder die Ablieferungen eingestellt zu werden. (...)

${ }^{674}$ Artículo 274: Todas las entradas y salidas de los tesoros públicos deben estar incluidas y autorizadas en el Presupuesto respectivo. No se percibirán entradas por impuestos que la Ley no haya establecido ni se pagarán gastos no previstos en el Presupuesto.

${ }^{675}$ Cf. Villegas, Hector Belisario. Curso..., p. 130.

${ }^{676}$ Rendas..., p. 54-55. "Do que aí está se conclui, sem sombra de dúvida, que o renomado mestre [VEIGA FILHO] laborava no mesmo equívoco de muitos outros, especialmente certos autores franceses, de que ele se nutria: confusão do princípio da universalidade orçamentária (todas as receitas e despesas do governo devem integrar-se no mecanismo orçamentário, para que se submetam ao seu regime) com o da unidade (nada tem a ver com a universalidade, nem com a questão de exclusão de matéria que lhe seja estranha ou que não represente, efetivamente uma atividade de ordem financeira; é um princípio antes normativo do que positivo porque impede que se elaborem tantos orçamentos quantos sejam as administrações especiais, atentando-se, portanto, na questão do orçamento único e na dos orçamentos múltiplos: confusão de especialização (princípio que proscreve englobamentos exagerados das verbas orçamentárias, a fím de que não possam ser aplicadas ou utilizadas em misteres contrários aos da autorização e não ultrapassem as somas ou valores realmente consignados) com multiplicidade orçamentária ou o contrário de orçamento único (unidade)." (grifos do autor) 
MANOEL DUARTE ${ }^{677}$-, pressupunha a existência de orçamentos ordinários e extraordinários: para o autor português, a existência da unidade ou pluralidade orçamental dependerá das circunstâncias fáticas e peculiares às quais se submete o Estado em determinado lapso temporal.

Volvendo à advertência do autor brasileiro sobre o perigo de confusão doutrinária, entendemos que a sua ocorrência subjaz-se à coincidência inerente dos fundamentos justificadores destes princípios. Já na opinião da doutrina francesa, o caixa único destaque-se - garantiria a quantidade de despesas, mas não a identidade de despesas, no entender de LOUIS TROTABAS e JEAN-MARIE COTTERET ${ }^{678}$. O princípio da universalidade pregaria, desta maneira, pela existência de um caixa único que garanta a não evasão de receitas a fins previamente vinculados, como ocorria com o ship money inglês para os gastos do rei. Diante desta necessidade moderna, a reforma de 1923 na Colômbia previu a unidade de caixa em prol da saúde financeira deste Estado ${ }^{679}$.

Em nossa opinião, o princípio da universalidade surge em uma concepção atual não em virtude da unidade de caixa - já que esta regra é corolária da unidade orçamentária -, mas sim como uma função contábil de inscrever todas as receitas e despesas estatais na forma bruta, como em um sistema de partida dobrada utilizado na contabilidade pública. Ademais, o respeito a este método é uma obrigação legal aos gestores públicos brasileiros, conforme os ditames do artigo 86 da Lei ${ }^{\circ} 4.320 / 64$ - o qual reforça a universalidade nesta faceta contábil. Logo, daí exsurgirá a sua função política de garantir a clareza nas contas públicas, ao tornar o orçamento mais claro para a análise do povo e de seus representantes, promovendo, também, a transparência fiscal ${ }^{680}$.

Sob esta ideia de completude, JosÉ AFONSO DA SILVA ${ }^{681}$ explica que a universalidade tem características de totalização e globalização, sendo um princípio do orçamento global, dado que as despesas e receitas deverão ser por dotações globais, inclusive da Administração descentralizada. Já a não vinculação refere-se a aspectos parciais do orçamento, porém, sem nenhuma conotação de somenos importância.

\footnotetext{
${ }^{677}$ Questões de finanças. Coimbra: Francisco França Amado Editor, 1893, p. 52 e 78-82.

${ }^{678}$ Droit..., p. 250.

${ }^{679}$ Cf. JARAMILlo, Esteban. Tratado de ciencia de la hacienda pública. 2. ed. Bogotá: Minerva, 1930, p. 570.

${ }^{680}$ SÉRgio AsSONi FILHO (Transparência fiscal e democracia. Porto Alegre: Nuria Fabris, 2009, p. 170-71) demonstra a existência desta ligação entre o controle social do orçamento e a transparência fiscal.

${ }^{681}$ Curso de direito constitucional positivo. 23. ed. São Paulo: Malheiros, 2004, p. 724-25 e Tributos..., p. 102.
} 
Assim, condensaríamos que o princípio da universalidade comporta a inscrição de todas as receitas e despesas orçamentárias pelo seu valor bruto, de forma a possibilitar a ciência detalhada e controle das contas públicas de forma global.

\subsubsection{CONCEPÇÃO DOUTRINÁRIA INTEGRATIVA DOS PRINCÍPIOS}

$A b$ initio, é oportuno destacar que a preocupação pelo estudo dos princípios da universalidade, unidade e não afetação é oriunda da tentativa doutrinária dos financistas em se evitar as constantes violações ao sistema orçamentário, ou outras manobras que impeçam a correta aplicação das normas orçamentárias ${ }^{682}$. Inclusive, alguns ordenamentos - como o italiano - sequer preveem a não afetação como princípio, razão pela qual a doutrina financista itálica mais moderna não a relaciona como princípio do bilancio $^{683}$.

Contudo, há por vezes a concepção implícita da não afetação extraível de outros princípios $^{684}$, como demonstra CESARE COSCIANI ${ }^{685}$ ao conceituar o princípio da unidade: “em outras palavras não se pode vincular (vincolare) uma dada despesa à gestão de uma determinada entrada ou, melhor, destinar a gestão de um tributo a uma determinada despesa".

Em vistas disto, muitas vezes é comum a miscelânea de conceitos extraídos dos princípios, conforme é possível verificar na doutrina pátria mais moderna. JAMES GIACOMONI $^{686}$, v. g., ao explicar a razão do princípio da universalidade, justifica com base em regra caudatária do princípio da unidade: "o dispositivo era claro: as entidades públicas financeiramente auto-suficientes não tinham suas receitas e despesas agregadas ao orçamento central." A doutrina mais clássica costumava até estudá-los em conjunto ${ }^{687}$, utilizando a não afetação como imperiosa para a universalidade orçamentária ${ }^{688}$.

\footnotetext{
${ }^{682}$ Cf. Ellwood, John W.; SpRAgUe, Mary. Options..., p. 343. Por conta disto que a doutrina mais vetusta como JoÃo PEDRo da VeIGA FILHO (Manual..., p. 259) - costumava apontar as ideias de clareza, unidade e universalidade orçamentárias em um mesmo princípio.

${ }^{683}$ Cf. POLLARI, Nicolò. Scienza delle finanze. Roma: Laurus Robuffo, 1995, p. 112-14.

${ }^{684} \mathrm{E}$, conforme visto, JOSÉ JUAN FERREIRO LAPATZA (Ver item 3.5.1.1 supra), um dos expoentes no tema no direito europeu, entende que o princípio da unidade lato sensu englobaria todos os demais.

${ }^{685}$ Scienza..., p. 503.

686 Orçamento..., p. 68.

${ }^{687}$ Cf. AHUMADA, Guillermo. Tratado..., p. 740.

${ }^{688}$ Cf. DEODATO, Alberto. Manual..., p. 296-97. E, para a consagração da universalidade, o autor entende que deve haver a reunião de receitas e despesas em um documento único, demonstrando esta tendência pela mescla conceitual dos princípios.
} 
JACOB WILNER SUNDELSON ${ }^{689}$ evidencia esta concepção comumente encontrada na doutrina europeia:

$\mathrm{Na}$ literatura é possível encontrar muitos autores confundindo este princípio [universalidade] com o princípio da unidade ou a não afetação de receitas. Em muitos casos o mal-entendido é devido ao fato de que os autores são inclinados a agrupar as noções de unidade e universalidade e discuti-las sob uma mesma linha. (destacou-se)

Pois bem, traçado o panorama acerca dos princípios da unidade e universalidade, é oportuno deixar registrado - conforme a doutrina mais especializada entende - que em regra propugna-se por uma concepção integrativa destes princípios ${ }^{690}$, em que pese às diferenciações doutrinárias vindas posteriormente, conforme aponta OSCAR JOSÉ DE PlÁCIDO E SILVA ${ }^{691}$ :

A unidade refere-se, principalmente, à multiplicidade de orçamentos, não a universalização ou totalização de receitas pelo seu todo, sem importar as verbas dispendidas ou os gastos próprios à sua produção, cuja dedução nos daria a receita líquida, que é da essência do princípio da universalidade.

A multiplicidade de orçamentos, infração ao princípio da unidade, não importa na insubmissão do princípio da universalidade. Para que esta se cumpra é necessário, simplesmente, que tôdas despesas pertencentes à administração, e tôdas as receitas, tambem a ela referentes, se integrem totalmente nêle. E se o orçamento se subdivide ou atende parte de serviços ou departamentos administrativos, será universal desde que atenda à totalidade de despesas e receitas próprias a êles.

Esta tendência prosperou na literatura europeia da segunda metade do século XX, bem como em alguns doutrinadores da América Latina. Neste continente, a tendência foi diferenciá-los totalmente, como faz MANUEL DE JUANO ${ }^{692}$ ao dizer que a universalidade não se confunde com a unidade, dado que esta consiste na existência de um único orçamento - em uma concepção estrita do conceito de unidade.

Na Europa, FERNANDO SAINZ DE BUJANDA ${ }^{693}$ concebia a regra da não afetação de receitas dentro do princípio da unidade - já que este supõe o princípio da unidade de caixa que, por sua vez, é decorrência final do princípio da universidade, ex vi do estabelecido no artigo $4^{\circ}$ da Lei de Administração e Contabilidade espanhola ${ }^{694}$, onde há proibição da existência de caixas especiais. Sem embargo, ressalta que o cumprimento da regra da

${ }^{689}$ Budgetary..., p. 245-46.

${ }^{690}$ Cf. STOURM, René. Le budget..., p. 150. Apenas para menção, a doutrina da época propunha que a unidade orçamentária derivaria da universalidade.

${ }^{691}$ Noções..., p. 50-51.

${ }^{692}$ Curso..., p. 381.

${ }^{693}$ Notas..., p. 625 e 635-36.

${ }^{694}$ La suma de los caudales públicos, incluso los reintegros de pagos indebidos y el producto en venta de los efectos que se enajenen en todos los ramos del servicio del Estado, se reunirán en el Tesoro o en sus dependencias. 
unidade de caixa não comporta a da não afetação de receitas automaticamente, considerando que os ingressos, a despeito de se centralizarem em um único caixa, podem vir a ser afetados a determinados gastos.

Mas, no entender do jurista, em última análise a não consignação é a aplicação contábil do princípio da universalidade, proibindo justamente a cobertura de gastos determinados a expensas das receitas ${ }^{695}$. Neste sentido, o belga FERNAND BAUDHUIN ${ }^{696}$ entende que a universalidade excluiria a afetação das receitas, apesar daquele país frequentemente excepcionar o princípio com afetações de tributos à exportação ou direitos de licença à importação, o que infirmava a própria a regra da não consignação.

Louis Trotabas e JeAn-MARIE COTTERet ${ }^{697}$, nesta concepção integrativa, pregam que o princípio da universalidade é complementar à unidade do orçamento, cuja composição envolve o produto bruto e a não afetação de receitas ${ }^{698}$. Entendem, portanto, que não seriam duas regras distintas, mas sim uma mesma ideia revista sob dois aspectos diferentes: a de que o orçamento deve conter o total das receitas e despesas, e que este total importará na inscrição detalhada de cada autorização orçamentária.

GIOVANNI INGROSSO ${ }^{699}$ também possui a mesma opinião, apenas alterando a ordem dos fatores, entendendo que o princípio da unidade completa o da universalidade, dado que "todas as entradas e despesas devem estar previstas no orçamento (universalidade) e em sua inteireza (integridade), mas é ainda necessário que o orçamento constitua um todo unitário (...)".

JULIEN LAFERRIÈRE e MARCEL WALINE ${ }^{700}$ expressam que a partir do momento em que o ordenamento jurídico concebe o princípio da não consignação, a universalidade seria uma decorrência necessária. Isto porque este seria um princípio insculpido no direito positivo, enquanto que o princípio da não afetação seria uma regra costumeira não positivada. Concebemos tal justificativa como superada, pois define o instituto não pelo que ele é - ou seja, pelo conteúdo -, mas sim pela sua forma ${ }^{701}$.

\footnotetext{
${ }^{695}$ Cf. SAINZ DE BuJANDA, Fernando. Notas..., p. 634.

${ }^{696}$ Précis..., p. 40-41.

${ }^{697}$ Droit..., p. 59.

${ }^{698}$ A universalidade como derivação do princípio da unidade também é defendida por FERNANDO PÉREZ RoYo (Derecho..., p. 370): “Como una ulterior derivación del principio de unidad presupuestaria, aparece el principio de universalidad o regla del 'presupuesto bruto', el cual tiene también un evidente parentesco con la regla de unidad de caja de la que acabamos de hablar."

${ }^{699}$ Corso..., p. 640.

700 Traité..., p. 94-95.

${ }^{701}$ Ver item 3.2 supra.
} 
Para os juristas, a universalidade decorre da noção de que não há despesa sem crédito, e, ipso facto, deve estar toda a receita contida no orçamento, para que, sendo necessária, sirva ao custeio de determinada despesa. Já a não consignação de receitas significa que toda receita destinada a determinada despesa deve ser certa e definida, a fim de receber o respectivo crédito. Desta forma, haveria a impossibilidade de se destinar uma receita que nem ao menos possa ser conhecida previamente - e também indeterminada.

Concluem então que "a universalidade orçamentária é, portanto, destinada a sancionar a impossibilidade de gastar sem crédito, e a não afetação de receitas, a necessidade de cada crédito ser calculado (determinado)." Em razão disto, os autores pregam que a regra da não consignação de receitas tem uma existência autônoma, razão pela qual deve ser considerada e estudada apartada das demais.

Diante destas posições, percebe-se como o significado exato de cada princípio, por vezes, queda-se confuso e incerto, havendo diversas remissões dos aspectos de um princípio em outro correlato. Logo, passando-se pela mescla doutrinária para uma concepção mais integrada, também entendemos que os princípios podem ser analisados de forma integrativa, mas são, em seu âmago, conceitualmente diferentes.

Há a possibilidade de serem concebidos conjuntamente - mas com a necessária diferenciação entre si -, abarcando os seus diversos aspectos de forma interligada, pois a universalidade e unidade congregam as características mais basilares do orçamento e daí poderão derivar os demais princípios de igual importância, como a não afetação. Assim, relacionam-se entre si, complementando os aspectos de cada um dos princípios analisados. Foi, nesse sentido, que o estudo doutrinário europeu evoluiu ${ }^{702}$.

Destarte, nesta concepção integrativa, as receitas e despesas públicas devem ser consideradas sob um liame lógico-orçamentário - seguindo uma unidade de desígnios (unidade) -, evitando-se contas apartadas ou paralelas ao orçamento (não afetação). Também devem ser concebidas na forma bruta como melhor técnica contábil, visto que deverão ser inscritas sem deduções, de forma clara e global (universalidade), sendo vedado o estabelecimento de ligações jurídicas (não afetação) que prejudiquem estas inscrições.

${ }^{702}$ Cf. Sundelson, Jacob Wilner. Budgetary..., p. 245-46. "Buck, Graziani, Lotz, Masé-Dari, Moll, Schanz e Willoughby estão entre aqueles que mencionam esta combinação de ideias. Há, além do mais, um consenso na opinião destas autoridades de que estes conceitos juntos expressam as ideias fundamentais relacionadas a qualquer orçamento." 


\subsection{PRINCÍPIO DA NÃO VINCULAÇÃO EM OUTROS ORDENAMENTOS JURÍDICOS E SUAS EXCEÇÕES}

A despeito de MARCos ANDRÉ VinHAS CATÃo ${ }^{703}$ mencionar que os países que consagram o princípio da não afetação de forma mais veemente são aqueles que, normalmente, possuem menor controle de seus gastos públicos, é possível observar o aparecimento deste postulado basilar nos ordenamentos de países modernos, sobretudo na Europa - como França e Portugal.

LOUIS CARTOU ${ }^{704}$ demonstra que, já na Comunidade Econômica Europeia, havia a preocupação em se entranhar o princípio da não afetação no ordenamento jurídico. No artigo 2, alínea 2 do Regulamento Financeiro da CEE de 1968 havia a previsão genérica do princípio, salvo as exceções previstas no artigo 11.

Atualmente, o Regulamento Financeiro Europeu (Regulamento CE, Euratom 1605/2002 do Conselho $)^{705}$ prevê a não afetação de receitas ínsita ao princípio da universalidade, conforme aponta MARCOS ANDRÉ VINHAS CATÃO ${ }^{706}$. RAMÓN FALCÓN Y TELLA $^{707}$ registra algumas importantes exceções à regra da não vinculação no âmbito da União Europeia:

a) as contribuições dos Estados-membros destinadas a financiar programa de desenvolvimento;

b) as rendas de fundações, subvenções, doações, legados e outros ingressos que tenham um destino efetivo, fato este que conservará a afetação;

c) mais recentemente, o artigo $6^{\circ}$ da proposta de nova Decisão sobre recursos próprios, de 1988, donde se extraem dispositivos específicos no tocante à reserva monetária do FEOGA-Garantia (Fundo Europeu de Orientação e Garantia Agrícola).

\footnotetext{
${ }^{703}$ Novas..., p. 569-70.

${ }^{704}$ Droit..., p. 27.

705 O texto do regulamento registra: "Princípio da universalidade. De acordo com o conteúdo do princípio da universalidade, a totalidade das receitas do orçamento deverá cobrir a totalidade das despesas. Este princípio inclui duas regras relevantes: a não afectação e a não compensação. A regra da não afectação impede que uma receita específica financie uma despesa específica. O Regulamento Financeiro prevê derrogações a este princípio, nomeadamente nos casos das contribuições financeiras dos Estados-Membros relativas a certos programas de investigação, ou ainda das participações de países terceiros em actividades da Comunidade, no âmbito do Espaço Económico Europeu, por exemplo. A regra da não compensação estabelece que não poderá haver compensação entre receitas e despesas a fim de assegurar a apresentação exaustiva e completa do orçamento. Por conseguinte, as receitas e as despesas serão inscritas pelo seu montante integral. Serão apenas aceites as excepções previstas pelo Regulamento Financeiro ou pelas suas normas de execução."

${ }^{706}$ Novas..., p. 578-79.

${ }^{707}$ Introducción..., p. 355.
} 
Na França, a Lei Orgânica de 2001 (cujo acrônimo no idioma é LOLF) consigna que as receitas e despesas são consideradas em um cálculo único, como um orçamento geral, porém, com um regramento todo peculiar. Apesar de o artigo $6^{\circ}$, alínea três da LOLF e o artigo 18 da antiga ordonnance orgânica (59-2) de 1959 consagrarem o princípio da não afetação, a ressalva na alínea dois deste último dispositivo prevê que determinadas receitas possam ser afetadas $^{708}$. Com a vedação expressa no artigo 18 da autorização orgânica de 1959, explicava a doutrina que a afetação de receitas poderia deflagrar a certas despesas o verdadeiro gozo de uma garantia, de forma que desvirtuaria a justificativa das despesas - isto é, a sua razão de existir e igualdade perante as demais ${ }^{709}$.

O artigo 16 da Lei Orgânica prevê três exceções ao princípio, a saber:

1. Orçamentos anexos: são justificados pela concepção comercial da gestão pública;

2. Recursos especiais do Tesouro: são criados para vincular os recursos a certos tipos de operação, fazendo com que seja mais transparente, ao contribuinte, a aplicação do dinheiro arrecadado ao invés de submetê-lo à "massa" total dos recursos dos impostos arrecadados pelo Estado;

3. Casos especiais: há dois casos que escapam da regra geral:

a) Fundos de ajuda: são criados para fazer frente a determinadas doações, de forma que o doador vincule sua benesse a uma utilização predeterminada, como uma doação com encargo. Compreendem quatro tipos de receitas do orçamento geral do Estado, quais sejam:

a.1) participação financeira das pessoas físicas ou jurídicas no financiamento de despesas gerais realizadas pelo Estado;

a.2) reembolso de serviços prestados pelo Estado;

a.3) contribuições de órgãos internacionais, mormente da União Europeia, a atividades consideradas importantes pelo orçamento estatal; e

\footnotetext{
${ }^{708}$ Cf. BouvIER, Michel; EsClASSAN, Marie-Christine; LASSALE, Jean-Pierre. Finances..., p. 259, $262-64$.

${ }^{709}$ Cf. Trotabas, Louis, CotTERET, Jean-Marie. Droit..., p. 60.
} 
a.4) retenções operadas sobre determinados organismos em benefício do orçamento estatal, como, por exemplo, as instituídas aos fundos de reserva e garantia das caixas econômicas.

b) Procedimentos de restabelecimento de crédito: permite restituir a um serviço créditos consumidos de maneira equivocada. Outra face que também se expõe é no tocante à possibilidade de um ministério alienar os seus bens próprios a fim de reter os recursos advindos destas alienações, com o escopo de salvaguardar esta quantia de todas as afetações parlamentares ${ }^{710}$.

Além destas exceções, sustenta-se, conforme visto anteriormente ${ }^{711}$, que os tributos parafiscais também seriam uma ressalva à regra, ao atribuir recursos a certos organismos ou serviços personalizados ${ }^{712}$. Tal volume de exceções fez com que JEAN RIVOLI $^{713}$ concluísse que o princípio da não afetação não teria tanta imponência no direito orçamentário francês, visto que ele externaria a constante oposição existente entre a economia administrativa e a de mercado, o que demandaria a sua relativização.

Na Espanha, aponta GLORIA ALARCÓN GARCÍA ${ }^{714}$ que o princípio da não afetação aparece insculpido no artigo 27.3 $3^{715}$ da Lei Geral Orçamentária $n^{\circ}$ 47/2003, de 26 de novembro, reforçado na Lei Geral Tributária em seu artigo $27^{716}$. O Texto Refundido de la Ley Reguladora de las Haciendas (TR-LRHL) manteve o princípio da não afetação em seu artigo 165.2, excepcionando-o, nitidamente, em caso de recursos já afetados em seu ingresso.

Estas exceções são vistas pela doutrina como imprescindíveis que sejam por via de lei, sendo nula qualquer afetação estabelecida em normas administrativas, conforme

\footnotetext{
${ }^{710}$ Cf. TROtABAs, Louis, CotTeret, Jean-Marie. Droit..., p. 60, com relação a esta exposição das exceções.

${ }^{711}$ Ver item 1.4.3 supra e a nossa discordância à afirmação de que a parafiscalidade seja uma forma de afetação.

${ }^{712}$ Cf. Trotabas, Louis, CotTeret, Jean-Marie. Droit..., p. 61. Cf. também Laferrière, Julien; WALINE, Marcel. Traité..., p. 97.

${ }_{713}^{713}$ Le budget de l'Etat. Paris: Éditions du Seuil, 1969.

${ }^{714}$ Financiación..., p. 103. Aponta a autora que a disposição da TR-LRHL é semelhante à já existente no Real Decreto 500/1990, de 20 de abril, em seu artigo 10.1, que estabelece que "Sólo podrán afectarse a fines determinados aquellos recursos que, por su naturaleza o condiciones específicas, tengan una relación objetiva y directa con el gasto a financiar, salvo en los supuestos expresamente establecidos en las Leyes."

${ }^{715}$ Los recursos del Estado, los de cada uno de sus organismos autónomos y los de las entidades integrantes del sector público estatal con presupuesto limitativo se destinarán a satisfacer el conjunto de sus respectivas obligaciones, salvo que por ley se establezca su afectación a fines determinados.

${ }^{716}$ Apontada por RAFAel CALVo ORTEGa (Curso..., p. 81).
} 
salienta CARLOS PALAO TABOADA ${ }^{717}$ - considerando a sistemática legal dos diplomas supramencionados.

GLORIA ALARCÓN GARCÍA ${ }^{718}$ ressalta, por outro lado, que o TR-LRHL não dispõe que estas exceções ao princípio da não afetação devam ser por lei para os órgãos municipais, podendo ocorrer por uma simples ordenanza do gestor do Poder Executivo respectivo $^{719}$. Desta forma, a afetação de recursos pela Fazenda municipal poderia ser realizada pelos próprios órgãos locais, concedendo aos dirigentes maior maleabilidade de governança, desde que houvesse uma relação objetiva e direta com o gasto - consoante mencionado. Porém, ressalva que, noutros casos (como os previstos nos ordenamentos estatais e autônomos), há a necessidade imperiosa de que a afetação venha por uma ordenanza $a^{720}$.

Também ao tratar desta temática no ordenamento espanhol, FERNANDO SAINZ DE BUJANDA $^{721}$ frisa que as exceções ao princípio são previstas, em regra, nas disposições legais. Costuma-se admitir, e. g., afetação de recursos de certos serviços para cobrir os seus próprios gastos. Outrossim, há a possibilidade de se estabelecer imposto, já na sua criação, destinado a certos fins. Por fim, no tocante às vinculações-garantias, o autor lembra que o Estado que afeta ingressos a determinada obrigação, garantindo-a, consegue obter empréstimos mais facilmente e em condições mais favoráveis.

Em Portugal, há a possibilidade constitucional aos entes autônomos de afetarem receitas às suas despesas específicas ${ }^{722}$. O princípio da não consignação de receitas, por outro lado, possuía outrora regramento infraconstitucional na Lei no 6/91, nos itens "1" e “2" do artigo $6^{\mathbf{0} 723}$. Atualmente, tal princípio está abarcado pela Lei de Enquadramento Orçamental 91/2001. O artigo $7^{\circ}$ dispõe em seu item “1” a regra geral e, no item "2”, as exceções:

\footnotetext{
${ }^{717}$ Apud GARCíA, Gloria Alarcón. Financiación..., p. 103, nt. 26.

${ }^{718}$ Financiación..., p. 103-04.

719 Entendemos que, conforme já demonstrado (ver item 1.3 supra), vinculações que não sejam por via legislativa não possuem a força jurídica para subsistirem como tais, mas poderiam se sustentar pelo seu caráter político-econômico.

${ }^{720}$ Cf. GARCía, Gloria Alarcón. Financiación..., p. 105.

${ }^{721}$ Notas..., p. 635.

${ }^{722}$ Artigo 227, 1, j, da Constituição da República Portuguesa de 2005: "1. As regiões autónomas são pessoas colectivas territoriais e têm os seguintes poderes, a definir nos respectivos estatutos: (...); j) Dispor, nos termos dos estatutos e da lei de finanças das regiões autónomas, das receitas fiscais nelas cobradas ou geradas, bem como de uma participação nas receitas tributárias do Estado, estabelecida de acordo com um princípio que assegure a efectiva solidariedade nacional, e de outras receitas que lhes sejam atribuídas e afectá-las às suas despesas."

${ }^{723}$ Cf. TEIXEIRA RIBEIRO, José Joaquim. Lições..., p. 89-90. Já nesta época o autor alertava para a existência de muitas exceções, fato este que se assemelha, em muito, ao ordenamento brasileiro atual.
} 
Artigo $7 .^{\circ}$

Não consignação

1 - Não pode afectar-se o produto de quaisquer receitas à cobertura de determinadas despesas.

2 - Exceptuam-se do disposto no número anterior:

a) As receitas das reprivatizações;

b) As receitas relativas aos recursos próprios comunitários tradicionais;

c) As receitas do orçamento da segurança social afectas ao financiamento dos diferentes subsistemas;

d) As receitas que correspondam a transferências provenientes da União Europeia, de organizações internacionais ou de orçamentos de outras instituições do sector público administrativo que se destinem a financiar, total ou parcialmente, determinadas despesas;

e) As receitas que correspondam a subsídios, donativos ou legados de particulares, que, por vontade destes, devam ser afectados à cobertura de determinadas despesas;

f) As receitas que sejam, por razão especial, afectadas a determinadas despesas por expressa estatuição legal ou contratual.

(...)

Na América Latina, pode-se verificar, na Argentina, que a doutrina expressava que o princípio vinha inscrito na lei de contabilidade pública (Decreto Ley $\mathrm{n}^{\circ}$ 23.354/56), no artigo $3^{\circ}$, ponto 1 , in fine ${ }^{724}$. Contudo, com a revogação do diploma pela Ley $\mathrm{n}^{\circ}$ 24.156/92 (a nova Ley de Administración Financiera - LAF), ficou disposto adrede no artigo 23 que:

Art. 23. No se podrá destinar el producto de ningún rubro de ingresos con el fin de atender específicamente el pago de determinados gastos, con excepción de:

a) Los provenientes de operaciones de crédito publico;

b) Los provenientes de donaciones, herencias o legados a favor del Estado nacional, con destino específico;

c) Los que por leyes especiales tengan afectación especifica.

Na Colômbia, o artigo 359 previu o princípio da não afetação constitucionalmente de forma explícita - tal como é feito no ordenamento brasileiro -, excetuando, como no caso pátrio, as verbas para o federalismo participativo, as destinadas aos investimentos sociais e consignações com amparo em leis anteriores a entidades de assistência social e às antigas intendencias (divisões administrativas) e comisarías.

No México, o artigo $6^{\circ}$ do anterior Código Fiscal da Federação prescrevia que somente por lei é que se pode haver a afetação de receitas. Segundo SERGIO FRANCISCO DE LA GARZA $^{725}$, as principais afetações existentes no ordenamento mexicano são: imposto sobre a exploração pesqueira, imposto sobre o consumo de energia elétrica, imposto sobre

${ }_{724}$ Cf. Fonrouge, Carlos M. Giuliani. Derecho..., v. I, p. 170-71.
${ }^{725}$ Derecho..., p. 187. 
ingressos por serviços telefônicos, imposto sobre a migração, imposto sobre veículos a diesel ou GLP e imposto sobre pneus e câmaras borracha.

Quanto à Constituição de El Salvador, o artigo 224, ao dispor sobre a Fazenda Pública, estabelece o princípio da não afetação a contrario sensu ao mencionar que "todos los ingresos de la Hacienda Pública formarán un sólo fondo que estará afecto de manera general a las necesidades y obligaciones del Estado.” Apesar de não tratar especificamente do orçamento, dispõe que as rendas auferidas pela Fazenda Pública ingressarão no total de recursos estatais de forma uniforme, por meio de uma vinculação geral.

Em ordenamentos anglo-saxões, é possível verificar o princípio da não afetação nos Estados Unidos, como na Constituição da Geórgia de 1945:

The appropriation for each department, officer, bureau, board, commission, agency, or institution for which appropriation is made, shall be for a specific sum of Money, and no appropriation shall allocate to any object, the proceeds of any particular tax or fund or a part or percentage thereof ${ }^{726}$.

Tal dispositivo ficou conhecido na doutrina como anti-earmarking clause, corolário da General Fund Clause, consagrando o princípio da não afetação de receitas e barrando novas vinculações por medidas infraconstitucionais - porém, ressalvando diversas opções, conforme ocorreu no modelo constitucional brasileiro ${ }^{727}$. Entretanto, nos Estados Unidos as vinculações a fundos são tão numerosas (aproximadamente vinte) que tal cláusula não costuma ser aplicada, principalmente no âmbito federal - onde se concentram os mais preeminentes casos de vinculação ${ }^{728}$.

IVES GANDRA DA SILVA MARTINS ${ }^{729}$ cita outros dispositivos análogos à não afetação de receitas, como o artigo 54 da Constituição da Coreia do Sul e o artigo VI, Seção 24 da Constituição das Filipinas. Sem embargo, não entendemos que sejam hipóteses de previsão do princípio da não vinculação de receitas de forma nítida.

O artigo VI, Seção 24 da Constituição filipina prescreve:

Section 24. All appropriation, revenue or tariff bills, bills authorizing increase of the public debt, bills of local application, and private bills, shall originate exclusively in the House of Representatives, but the Senate may propose or concur with amendments.

Observamos que, a rigor, o mencionado preceito estabelece que determinadas matérias afetas ao orçamento - inter alia, tais como aumento do débito público e

\footnotetext{
${ }^{726}$ Cf. a menção em ALEXANDER, Frank S. Financing..., p. 369.

${ }^{727}$ Cf. AlEXANDER, Frank S. Financing..., p. 370-72.

${ }^{728}$ Cf. CAMIC, Susannah. Earmarking..., p. 60-61.

${ }^{729}$ Comentários..., p. 343.
} 
arrecadação de receitas - devem ser originadas da Casa Legislativa específica, de forma que haja um procedimento especial.

Já o artigo 54 da Constituição da Coreia do Sul consigna:

Article 54 [Budget]

(1) The National Assembly deliberates and decides upon the national budget bill.

(2) The Executive formulates the budget bill for each fiscal year and submits it to the National Assembly within ninety days before the beginning of a fiscal year. The National Assembly decides upon it within thirty days before the beginning of the fiscal year.

(3) If the budget bill is not passed by the beginning of the fiscal year, the Executive may, in conformity with the budget of the previous fiscal year, disburse funds for the following purposes until the budget bill is passed by the National Assembly:

1) The maintenance and operation of agencies and facilities established by the Constitution or law;

2) Execution of the obligatory expenditures as prescribed by law; and

3) Continuation of projects previously approved in the budget.

Mais uma vez, apenas há a menção sobre os procedimentos adotados pela Casa Legislativa para deliberação do orçamento, salientando que, caso não haja a tempestiva apreciação, o Executivo pode despender recursos para determinados objetivos até a feitura da peça orçamentária.

Por derradeiro, cumpre salientar que o princípio da não afetação não encontra guarida em alguns ordenamentos constitucionais, tais como o russo, holandês, checo, suíço (apesar de o artigo 126 prever o princípio do equilíbrio orçamentário), húngaro, dinamarquês e boliviano.

\subsection{RELATIVIZAÇÃO DO PRINCÍPIO DA NÃO VINCULAÇÃO DE RECEITAS}

No direito financeiro moderno, o que se observa cada vez com mais frequência é a tendência pela flexibilidade do princípio inibidor das vinculações ${ }^{730}$. Esta concepção surge, inclusive, com as mudanças político-sociais ocorridas: em verdade, o soerguimento de serviços públicos autônomos dissociados do orçamento geral e com formas de arrecadações peculiares fez com que houvesse um cambiamento no paradigma orçamentário do último século ${ }^{731}$.

\footnotetext{
${ }^{730}$ Cf. CATÃo, Marcos André Vinhas. Novas..., p. 573. A rigidez do princípio é apontada pelo autor como um dos fatores que dificulta a justiça tributária.

${ }^{731}$ Cf. VILlaReJO, Avelino García; SANCHEZ, Javier Salinas. Manual..., p. 178.
} 
FERNANDO SAINZ DE BUJANDA ${ }^{732}$ pondera que há diversas quizilas no que concerne ao princípio da não afetação de receitas. Uma das críticas - já ventilada - é que tal prática não seria compatível com a gestão comercial dos serviços públicos, tendo em vista o imperativo de que os recursos destes serviços fiquem afetados aos seus gastos.

Ocorre que HeCTOR BELISARIO VILLEGAS ${ }^{733}$ destaca a prática recorrente de alguns países em excepcionar a regra da unidade mediante as inúmeras afetações de receitas oriundas do crescimento do intervencionismo estatal. Segundo o autor, houve o surgimento de uma "Fazenda composta", com várias "Fazendas anexas" oriundas da descentralização administrativa. Destarte, as entidades dotadas de certa autonomia, como as autarquias, passaram a ter um orçamento próprio, dissociado do orçamento geral.

Porém, em atenção a este problema, é possível verificar que, na França, os orçamentos anexos incumbiram-se de conceder esta autonomia financeira, sem prejuízo da eficiência da máquina estatal ${ }^{734}$. Em contrapartida, reconhece FERNANDO SAINZ DE BUJANDA $^{735}$ que a mantença da regra da não afetação é inexorável, sob pena de violação do princípio de justiça equitativa dos cidadãos perante os recursos públicos ${ }^{736}$. Na Europa, tendo em consideração que não há vedação constitucional taxativa, há maior maleabilidade diante da casuística, de forma que, neste sistema jurídico, o caso concreto é que dirá se, por critérios de oportunidade, a vinculação se faz devida ${ }^{737}$.

GUILLERMo AHUMADA ${ }^{738}$ entende que o princípio da não afetação só pode ser relativizado no caso dos fundos de empréstimos públicos, visto que, como o empréstimo tem uma finalidade específica na sua contração, esta não poderia ser desviada - salvo por motivos de segredo militar durante guerras, por exemplo. Tirante esta hipótese, a alocação

\footnotetext{
${ }^{732}$ Notas..., p. 635.

${ }^{733}$ Curso..., p. 129. Para o jurista argentino, a vinculação de receitas afeta o ponto crucial do sistema orçamentário, que é a unidade. Ver item 3.5.1 supra.

${ }^{734}$ RAYMOND MUZELLEC (Notions..., p. 229) expõe três razões para a derrogação do princípio - já mencionadas no trade-off (ver item 1.6.2 supra) - usadas para justificar as vinculações: (i) financeira: a afetação para o reembolso de empréstimos pode ter sua utilidade - esta, a nosso ver, trata-se de uma típica vinculação-garantia; (ii) técnica: a afetação permite ao setor privado avaliar melhor os custos de suas atividades; e (iii) política: uma vinculação de imposto popular a uma despesa também popular pode fazer com que a oposição não seja tão ferrenha ao vetar a instituição de um determinado tributo. Porém, ALAN RICHMOND PREST (Public..., p. 124, nt. 1) entende que nada impede um aumento do imposto de renda, por exemplo, para custear a expansão de determinado gasto, mas sem que haja a expressa segregação destas receitas.

${ }^{735}$ Notas..., p. 635.

${ }^{736} \mathrm{O}$ artigo 31.2 da Constituição Espanhola estabelece a asignación equitativa dos recursos públicos, em homenagem à justiça equitativa na distribuição.

${ }_{737}^{7}$ Cf. SAINZ DE BUJANDA, Fernando. Notas..., p. 635.

${ }^{738}$ Tratado..., p. 745.
} 
dos recursos deve obedecer aos critérios político-econômicos ${ }^{739}$ de distribuição segundo a necessidade estatal.

No direito pátrio, quem defende a relativização do princípio da não vinculação de receitas é José MARCos Domingues DE OLIVEIRA ${ }^{740}$. O autor entende que o conceito que envolve o artigo 167, IV, da Carta Magna não pode se quedar estratificado ante o despontamento de novos valores e necessidades sociais relevantes. Porém, não propõe, em seu estudo, a alteração da concepção do instituto, e sim a mudança do dispositivo constitucional, a fim de permitir a vinculação de receitas para fins ambientais, bem como a inclusão de uma permissiva constitucional que concederia à lei complementar o condão de vincular determinada receita. Eis a proposta de redação do jurista:

Art. 167 - São vedados:

I a III - Omissis;

IV - a vinculação de receita de impostos a órgão, fundo ou despesa, ressalvadas a repartição do produto da arrecadação dos impostos a que se referem os arts. 158 e 159, a destinação de recursos para manutenção e desenvolvimento do ensino e para prover a preservação do meio ambiente e a recuperação de áreas degradadas, como determinado nos arts. 212 e 225, $\S 7^{\circ}$, a prestação de garantias às operações de crédito por antecipação de receita, previstas no art. $165, \S 8^{\circ}$, e nos demais casos previstos por lei complementar. (destacou-se)

A proposta com relação às questões ambientais pode até subsistir juridicamente pelo seu caráter extrafiscal, porém, é difícil defender a permanência da existência do instituto com a permissão de criação de vinculações por lei complementar. Esvaziar-se-ia, por fim, qualquer tentativa de se estabelecer um rol taxativo das vinculações constitucionais, pois na prática estar-se-ia derrogando o princípio da não vinculação no âmbito constitucional, permitindo constantes ingerências de leis complementares sobre o tema, como ocorria nos diplomas constitucionais de 1967 e 1969. Ademais, colidiria com a atual tendência doméstica de se criar mecanismos mais hábeis e maleáveis de desvinculação de recursos orçamentários.

Por fim, cumpre destacar que, no Brasil, a forma típica de relativização ou mitigação do princípio da não vinculação é mediante a criação de fundos específicos, que ora serão delineados.

\footnotetext{
${ }^{739}$ Ressalte-se, por oportuno, que RICARDO LOBO TORRES (Tratado..., p. 338) entende ser a vinculação instrumento não totalmente democrático.

${ }^{740}$ Meio-ambiente..., p. 89-90.
} 


\section{MECANISMOS MITIGADORES DA NÃO AFETAÇÃO E DAS VINCULAÇÕES DE RECEITAS NO BRASIL}

\subsection{VINCULAÇÃO DE RECEITAS A FUNDOS ESPECÍFICOS}

A forma mais comum de vinculação de receitas é aquela instrumentalizada por fundos $^{741}$ específicos e finalidades previamente determinadas, de forma a se mitigar o princípio da não afetação de despesas ${ }^{742}$. O conceito sintético de fundo, segundo CARL COPPING PLEHN ${ }^{743}$, é exposto como "uma apropriação para um propósito específico ou para um grupo de propósitos". Como as vinculações têm o seu propósito predeterminado, os fundos são ferramentas úteis para operacionalizá-las.

Para a constituição dos fundos, HORACIO GUILlERMO CORTI ${ }^{744}$ observa que a forma jurídica comumente utilizada é pela afetação específica de receitas, mediante diversos diplomas legislativos e muitas vezes com regimes jurídicos próprios. $\mathrm{Na}$ realidade, os fundos, juntamente com as contas especiais e orçamentos anexos, são veículos para as vinculações.

É deveras relevante mencionar, todavia, a possibilidade de criação de um fundo sem que seja por afetação específica. Extrai-se este exemplo do Fundo de Reparação

\footnotetext{
${ }^{741}$ Cf. NUNES, Cleucio Santos. Dos fundos especiais. In: CONTI, José Mauricio (coord.). Orçamentos..., p. 204. O escopo do presente trabalho não é realizar a análise detida dos fundos e sua natureza jurídica, mas sim demonstrar a possibilidade de vinculação de receitas mediante este veículo orçamentário. No entanto, é oportuno mencionar as linhas que motivaram o surgimento desenfreado de fundos no Brasil: "Os registros históricos brasileiros sobre fundos criados e administrados pelo Poder Público datam do final do século XIX. Apesar disso, a maioria dos fundos foi implantada a partir dos anos 1970, provavelmente em razão da política de desenvolvimento econômico da época, que se pautava, como era notório, pela indiscreta intervenção do Estado no domínio econômico."

${ }^{742}$ Cf. Giacomoni, James. Orçamento..., p. 77. Os fundos, para o autor, são “(...) autênticos orçamentos independentes dentro do orçamento geral."

${ }^{743}$ Introduction to public finance. New York: The Macmillan company, 1931, p. 394, nt. 1.

${ }^{744}$ Derecho constitucional..., p. 312.
} 
Histórica para a Localização e Restituição das Crianças Sequestradas elou Nascidas em Cativeiro na Argentina (Ley $\left.\mathrm{n}^{\mathrm{o}} 25.066\right)^{745}$. Neste caso, ao invés de ser criado um fundo por afetação de recursos, foi instituída uma porcentagem fixa de gastos que a lei orçamentária deverá suprir com os recursos já autorizados ao Congresso Nacional, ou seja, a Casa deverá subtrair uma quantia de seu próprio orçamento a fim de custear este percentual de gastos ao fundo determinado.

HORACIO GUILlERMO CORTI ${ }^{746}$, analisando este fundo, entende que se trata de uma autolimitação legislativa de caráter orçamentário, visto que o próprio órgão responsável pelo orçamento cria uma regra que limita a sua autonomia orçamentária. Entendemos desta forma, adicionando que não se trataria de um fundo orçamentário oriundo de recursos vinculados conforme o conceito clássico, mas sim uma designação de despesa obrigatória que deverá ser suprida por recursos orçamentários de um dos Poderes a um fundo específico.

Em alguns países do Commonwealth, estes fundos são mais abundantes. Em regra, levam o nome da despesa para a qual foram criados, ou então da receita que os sustentam. Como a contabilidade pública tende a ser complexa, mormente em transferências de recursos de um fundo a outro, em alguns casos costumam aparecer de maneira dobrada, de certa forma arredondando e mascarando a arrecadação pública ${ }^{747}$.

Nos Estados Unidos, a prática corrente é de vinculação das receitas tributárias mormente dos impostos indiretos - a fundos específicos, donde se depreende a política dos superfunds, podendo ser citado, como exemplo, o CERCLA - Comprehensive Environmental Response, Compensation and Liability Act -, cuja afetação dos impostos sobre petróleo, produtos químicos e derivados possibilitou a instituição de uma política ambiental estadunidense ${ }^{748}$. Na França, outros exemplos de fundos que a doutrina costuma citar neste país são o Fundo Nacional da Solidariedade, Fundo Nacional de Habitação, Fundo Florestal Nacional, Fundos de ação local, Fundo Nacional de Desenvolvimento Agrícola, dentre outros ${ }^{749}$.

\footnotetext{
${ }^{745}$ Este fundo foi criado para sustentar os gastos que a Associação de Avós da Praça de Maio tem para localizar e identificar os seus netos desaparecidos por ocasião do regime militar argentino.

${ }^{746}$ Derecho constitucional..., p. 315.

${ }^{747}$ Cf. PLEHN, Carl Copping. Introduction..., p. 395.

${ }^{748}$ Cf. CATÃo, Marcos André Vinhas. Novas..., p. 568-69 e OliveIRA, José Marcos Domingues. Meioambiente..., p. 89.

${ }^{749}$ Cf. TROTABAS, Louis. Finances..., p. 664-65.
} 
WILliam MCCLEARY ${ }^{750}$ expõe o intenso uso de vinculações por fundos na Turquia mediante fundos extraorçamentários - diferentemente do que ocorreu na Colômbia, onde houve vinculações dentro do orçamento. A desvantagem desse sistema é que contribuiu pouco para o levantamento de recursos adicionais, além de não haver uma organização central e desconsiderar totalmente o princípio do benefício, representando vinculações sem correlação alguma entre receita e a respectiva benesse.

Ocorre que os fundos com dotações específicas são alvos de críticas ao serem aplicados em países em desenvolvimento, principalmente quando tratados a curto prazo. Ademais, a multiplicidade destes fundos conduz à indecisão dos ordenadores de despesas, sobretudo no caso da saúde, conforme expõe CATRIOnA WADDINGTON ${ }^{751}$. Percebe-se, destarte, que eles são mais fomentados nos países desenvolvidos.

A doutrina, adaptando-se à realidade orçamentária pátria - que utiliza os fundos apenas para que seja possível vincular receitas e despesas a fins específicos, de forma a não cair na restrição contida no princípio da não vinculação de receitas - conceitua fundo “(...) como um conjunto de recursos utilizados como instrumento de distribuição de riqueza, cujas fontes de receita lhe são destinadas para uma finalidade determinada ou para serem redistribuídas segundo critérios preestabelecidos." ${ }^{, 752}$

O importante a ser ressaltado, no ordenamento brasileiro, é que a vinculação de receitas a um gasto predeterminado é característica primordial no sistema de fundos especiais brasileiros. Tal fato deve-se em razão de:

Os fundos, como instrumentos que auxiliam o alcance de determinados fins de
desenvolvimento social ou econômico, trazem em sua lógica a necessária destinação de
suas receitas à realização das despesas que motivaram sua instituição. Seria
indisfarçável burla à lei orçamentária admitir-se desvinculação das receitas previstas
para aplicação nos fins que justificaram a criação do fundo. Além disso, há um
componente político que não pode ser descartado, qual seja, o comprometimento do
interesse público sotoposto à criação do fundo ${ }^{753}$.

Ademais, cumpre rememorar que deve haver também, dentre outras características, a vinculação a órgão específico da Administração, bem como a aplicação dos recursos na forma prevista na lei orçamentária ${ }^{754}$. Essa característica é relevante para destacar que os Fundos de Participação dos Estados e dos Municípios (FPE e FPM) não

\footnotetext{
${ }^{750}$ The earmarking..., p. 95-97.

${ }^{751}$ Does earmarked donor funding make it more or less likely that developing countries will allocate their resources towards programmes that yield the greatest health benefits? Bulletin of the World Health Organization. v. 82. n. 9. Genève. sept. 2004, p. 703-04.

${ }^{752}$ Cf. ConTI, José Mauricio. A autonomia..., p. 154.

${ }^{753}$ Cf. NunES, Cleucio Santos. Dos fundos..., p. 212.

${ }^{754}$ Cf. Nunes, Cleucio Santos. Dos fundos..., p. 211.
} 
podem ser considerados como instrumentos de consignação de receitas. Nestes Fundos existe a definição da fonte de custeio (os recursos partilhados para o federalismo fiscal), mas não há a destinação (a despesa determinada). Logo, são instrumentos de partilha que apenas servem para operacionalizar a repartição de receitas entre os entes federativos.

Diante disto, para o escopo específico deste trabalho, os fundos são instrumentos jurídicos que podem se prestar à afetação de recursos públicos, facilitando a identificação da fonte e destino preestabelecido e, consequentemente, a operacionalização destas verbas. Ressalve-se, entretanto, que isso não significa que todo fundo seja formado por recursos afetados. E os fundos de repartição de receitas entre entes federativos também não veiculam afetações, por não incluírem em seu escopo a destinação dos recursos (despesas).

\subsubsection{VINCULAÇÃO DE RECEITAS DE RECURSOS NATURAIS A FUNDOS}

Em que pesem às considerações já exaradas quanto ao trade-off das vinculações $^{755}$, a doutrina costuma mencionar certo sucesso na vinculação de receitas a fundos quando se trata de recursos oriundos da exploração dos recursos naturais estatais. Porém, ressalta também a advertência dos economistas de que a criação de fundos não seria a maneira mais adequada para se fazer frente aos problemas da dissipação de recursos oriundos da exploração destes bens naturais, pois sem um controle efetivo do endividamento tais medidas tornam-se inócuas ${ }^{756}$.

Entretanto, as vantagens apontadas pela doutrina jurídica são: (i) dificulta-se o surgimento de corrupção e desvio destes valores; (ii) destinam-se os recursos à promoção

\footnotetext{
${ }^{755}$ Ver item 1.6 supra.

${ }^{756}$ Cf. CARRETERO, Belén García. La financiación..., p. 408 e nt. 17: "Alguns economistas sustentam que a criação de fundos de recursos não é condição necessária nem suficiente para poder fazer frente aos problemas indicados na forma adequada. Em concreto, manifestam que não são necessários porque, em princípio, todas estas questões [desperdício de recursos pelos países em desenvolvimento] podem ser abordadas como elementos integrais da política orçamentária e fiscal do governo. Uma séria de países, incluídos a Austrália e Reino Unido, demonstraram com bastante êxito que é possível fazer frente a grandes e voláteis ingressos provenientes dos recursos naturais sem fundos de estabilização ou de poupança. Ao mesmo tempo indicam que estes fundos tampouco são suficientes em si porque, invariavelmente, alcançar os objetivos de política exige adotar outras decisões de política fiscal, sobretudo com relação ao controle do gasto e do endividamento. Por exemplo, um fundo para reduzir as variações do ingresso orçamentário procedente dos recursos naturais não garante um gasto estável a menos que também se controle o endividamento."
} 
das gerações futuras, além do que (iii) facilita-se a demonstração das vantagens oriundas da afetação destes recursos a um fundo específico ${ }^{757}$.

Diante disto, destacam-se algumas experiências bem-sucedidas, como o Fundo Governamental do Petróleo na Noruega, formado pelos recursos obtidos com a venda do petróleo e com o escopo principal de resguardar o uso, a longo prazo, dos recursos petrolíferos, bem como financiar o déficit previdenciário - este último escopo, em 2006, passou a constituir o ramo internacional do Fundo Governamental de Pensões. Neste país, então, pode-se afirmar que se obteve uma gestão racional dos seus recursos naturais por meio da transparência, controle e responsabilidade ${ }^{758}$.

MiKAEl SKOU ANDERSEN ${ }^{759}$ demonstra prática interessante ocorrida na Dinamarca com um programa de tributação sobre o carbono utilizado para produção de energia, cuja vinculação de $20 \%$ serviu para fomentar a eficiência energética (bem como a evolução tecnológica), impactando positivamente na produtividade e economia das companhias do setor.

Outros países também tiveram experiência com fundos formados por receitas oriundas de recursos naturais. O Timor Oriental criou o Fundo de Petróleo, com a destinação das receitas de petróleo e gás; o Chile criou o Fundo de Compensação do Cobre para se garantir das quedas e variações do preço deste metal, bem como das flutuações econômicas mundiais; Botsuana, com um terço do PIB vinculado à exploração de diamantes, possui, administrado pelo respectivo banco central, o Fundo Pula (80\%) e o Fundo de liquidez no mercado monetário (20\%).

Já no Chade, houve uma tentativa fracassada. Inicialmente, celebrou-se um acordo com o Banco Mundial com relação ao uso dos recursos naturais na seguinte disposição: $10 \%$ das verbas oriundas da atividade petrolífera seriam destinados a um fundo fiduciário para as futuras gerações. O restante seria dividido em três fundos: $80 \%$ para a luta contra a pobreza, $15 \%$ para o orçamento estatal e 5\% para o desenvolvimento regional da zona de exploração do petróleo. A concepção do plano parecia ótima até, em 2005, o presidente do país mudar esta distribuição, de forma que se aumentou para $30 \%$ a fatia destinada ao orçamento estatal. Segundo a doutrina, tais atos são oriundos do problema das constantes tentativas de corrupção dos dirigentes, requerendo, destarte, amplo controle externo e

\footnotetext{
${ }^{757}$ Cf. CARretero, Belén García. La financiación..., p. 409.

${ }^{758}$ Cf. CARRETERO, Belén García. La financiación..., p. 410-11.

${ }^{759}$ Environmental and Economic Implications of Taxing and Trading Carbon: Some European Experiences. Vermont Journal of Environmental Law. v. 10. 2008, p. 69.
} 
estabelecimento de algumas exigências para o bom cumprimento das medidas tomadas em favor da população ${ }^{760}$.

BELÉN GARCÍA CARRETERo ${ }^{761}$, com este panorama, expõe, para solver o problema da falta de infraestrutura nestes países, duas alternativas de aplicação destes recursos naturais: a primeira é que eles entrem no orçamento-geral destinados à criação de infraestrutura. A outra é no sentido de se criar um fundo extraorçamentário com estes recursos, que deverá ser transparente, administrado com responsabilidade e controlado interna e externamente, preferindo esta opção como a mais adequada.

Estes fundos delineados ficaram conhecidos na doutrina como fundos soberanos, que serão tratados a seguir.

\subsubsection{FUNDOS SOBERANOS}

É importante repisar que países em vias de desenvolvimento, para fomentar o crescimento econômico, costumam endividar-se a fim de adquirir o capital necessário aos investimentos nacionais. E, em regra, acabam dilapidando seus recursos naturais, conforme a tese levantada por BELÉN GARCÍA CARRETERO ${ }^{762}$.

Explica então que o problema não é da suficiência financeira, mas sim da máadministração dos recursos públicos, o que redunda em endividamentos superiores à capacidade normal de solvência estatal. Adicione-se, a isto, o problema da corrupção de seus dirigentes e uma infraestrutura parca: faz-se mister concluir que, apesar dos ingentes recursos naturais destes países, a sua administração é deficiente. É o que ocorre com a Zâmbia, Chade, Venezuela, Gabão, Sudão, Angola e Nigéria.

Desta forma, conforme visto, a vinculação de receitas poderia ser uma justificativa para sanar este problema de má-gestão financeira dos recursos naturais. Evitarse-ia o que se denomina de maldição dos recursos naturais, que é o que se sucede, por exemplo, com os países que possuem reservas de petróleo em abundância. Esta maldição consistiria em uma pífia taxa de crescimento destas nações em comparação proporcionalmente - a outras que não possuem tais reservas. Outro fator que causaria este mal seria a enfermidade ou doença holandesa, ou seja, a desindustrialização em virtude da

\footnotetext{
${ }^{760}$ Cf. estas experiências em CARRETERo, Belén García. La financiación..., p. 412-16.

${ }^{761}$ La financiación..., p. 418.

${ }^{762}$ La financiación..., p. 404-05.
} 
tendência de dependência, em determinada economia, da atividade econômica de exportação destes recursos naturais ${ }^{763}$.

Desta forma, os fundos soberanos (ou, literalmente, fundos de riqueza soberana $)^{764}$ foram instituídos, ao redor no mundo, em razão da exploração de commodities, e. g. o petróleo, em determinadas nações, como nos Emirados Árabes (Abu Dhabi Investment Authority - o maior, composto por quase 900 bilhões de dólares), Arábia Saudita (Saudi Arabian Monetary Agency) e Noruega (Government Pension Fund). Outros países constituíram fundos soberanos para estocar os recursos da elevada receita advinda de exportações em determinadas safras. Este é o caso de Cingapura (Government of Singapore Investment Corporation) e China (State Administration of Foreign Exchange Investment Company) ${ }^{765}$.

JOUKO RAUTAVA $^{766}$ explica que os primeiros fundos soberanos surgiram na década de cinquenta do século passado; já na década presente, houve uma eclosão no número destes fundos e exsurgiu, juntamente com este crescimento, a preocupação com a transparência e gestão destes instrumentos. A razão de sua criação era preservar a desvalorização cambial do dólar, de forma que não houvesse reflexo nas exportações ${ }^{767}$. Todavia, com o advento da crise financeira mundial de 2008, o excesso de recursos oriundos destas exportações acabou sendo reduzido, o que lhe retirou, ao menos durante esse período, a importância de sua constituição. Outros escopos, contudo, podem ganhar importância neste novo contexto, como, v. g., formar reservas para gerações futuras.

O Sovereign Wealth Fund Institute, contando já com o Sovereign Fund of Brazil, calcula que quase quatro trilhões de dólares da riqueza mundial estejam nestes fundos. Só de petróleo e gás chega-se à impressionante cifra aproximada de dois trilhões e meio de dólares $^{768}$. No Brasil, este fundo soberano recém-constituído foi objeto de algumas celeumas, que serão brevemente delineadas em seguida.

\footnotetext{
${ }^{763}$ Cf. CARretero, Belén García. La financiación..., p. 406.

${ }^{764}$ Um fundo soberano, segundo o Instituto dos Fundos Soberanos, "é um fundo de investimento estatal composto de ativos financeiros como ações, títulos, imóveis ou outros instrumentos financeiros, fundados por ativos em moeda estrangeira. Fundos Soberanos podem ser estruturas como um fundo, pool ou corporação. Alguns fundos também investem indiretamente em empresas estatais domésticas. Ademais, eles tendem a preferir retornos sobre liquidez, assim têm um maior risco de tolerância que as tradicionais reservas internacionais." Disponível em: <http://www.swfinstitute.org/swf.php>. Acesso em: 27 fev. 2009.

${ }^{765}$ Cf. GuAndalini, Guiliano. O fundo da discórdia. Revista Veja, São Paulo, 7 jan. 2009, p. 42.

${ }^{766}$ Sovereign wealth funds arouse political passions. Focus/Opinion: Expert view. Bank of Finland - Institute for Economies in Transition, BOFIT. n. 2. 14 abr. 2008, p. 1-2.

${ }^{767}$ Cf. GuANDALini, Guiliano. O fundo..., p. 40.

${ }^{768}$ Informações extraídas, passim, de <http://www.swfinstitute.org/>. Acesso em: 14 abr. 2010.
} 


\subsubsection{FUNDO SOBERANO DO BRASIL}

O Fundo Soberano do Brasil - FSB foi instituído pela Lei $\mathrm{n}^{\circ} 11.887$, de 24 de dezembro de 2008, com o escopo de "promover investimentos em ativos no Brasil e no exterior, formar poupança pública, mitigar os efeitos dos ciclos econômicos e fomentar projetos de interesse estratégico do País localizados no exterior", conforme o texto do artigo $1^{\circ}$ da lei citada.

Importante menção feita pelo diploma legislativo - e relevante para este trabalho - é que não pode haver a utilização de sua receita que não para o estrito escopo de suavizar os efeitos maléficos dos ciclos econômicos, cujos recursos serão destinados de acordo com as dotações orçamentárias da lei orçamentária anual. Outrossim, afasta-se qualquer tentativa de se tentar vincular a receita para programas governamentais diversos, assim como destinações para despesas obrigatórias de caráter continuado $\left(\operatorname{artigo} 5^{\circ}\right.$ ).

Ocorre que a Medida Provisória $n^{\circ}$ 452, de 26 de dezembro de 2008, alterou o referido diploma legislativo, permitindo à União emitir títulos da dívida pública mobiliária federal para compor os recursos do FSB, juntamente com outras hipóteses definidas no artigo $4^{\circ}$ da Lei $^{769}$.

Por conta destas alterações, os Democratas - DEM, o Partido da Social Democracia Brasileira - PSDB e o Partido Popular Socialista - PPS ingressaram com a Ação Direta de Inconstitucionalidade $n^{\circ} 4.179-7 / \mathrm{DF}$, visto que a forma de previsão de fonte de recursos esbarraria nos óbices contidos na Constituição Federal - ao prevê-los sem estarem consignados na Lei Orçamentária Anual de 2009. A referida Medida Provisória abriu créditos da monta de 14,2 bilhões de reais para a devida operacionalização do fundo ${ }^{770}$.

\footnotetext{
${ }^{769}$ Art. 4o Poderão constituir recursos do FSB:

I - recursos do Tesouro Nacional correspondentes às dotações que lhe forem consignadas no orçamento anual, inclusive aqueles decorrentes da emissão de títulos da dívida pública;

II - ações de sociedade de economia mista federal excedentes ao necessário para manutenção de seu controle pela União ou outros direitos com valor patrimonial; e

III - resultados de aplicações financeiras à sua conta.

IV - títulos da dívida pública mobiliária federal. (Incluído pela Medida Provisória nº 452, de 2008)

$\S 1$ o Os recursos do FSB, enquanto não destinados às finalidades previstas no art. 1o desta Lei, ficarão depositados na Conta Única do Tesouro Nacional.

$\S 20$ Fica a União autorizada a emitir, a valor de mercado, sob a forma de colocação direta em favor do FSB, títulos da Dívida Pública Mobiliária Federal. (Redação dada pela Medida Provisória $n^{\circ}$ 452, de 2008)

3o A União poderá resgatar antecipadamente, a valor de mercado, os títulos de que trata o § 2o. (Incluído pela Medida Provisória n ${ }^{\circ} 452$, de 2008)

${ }_{770}$ Cf. Guandalini, Guiliano. O fundo..., p. 41.
} 
Entre outras violações, a petição inicial proposta pela oposição do atual Governo Federal também indica o ferimento ao artigo 163 , IV, bem como ao artigo 165 , $\S 5^{\circ}$, I, da Constituição, ao desconsiderar os mandamentos do princípio da universalidade. Isto iria, segundo a argumentação exposta, de encontro à jurisprudência firmada pelo ex-Ministro Paulo Brossard no Supremo Tribunal Federal na relatoria da ADI n ${ }^{\circ} 225-2 / \mathrm{PR}^{771}$.

O que merece ser destacado é que, diferentemente dos demais fundos soberanos, o brasileiro aparece como uma poupança pública de recursos públicos - não necessariamente naturais - para proteger o país de vicissitudes econômicas. Desta forma, não vincula a receita oriunda de recursos naturais ou exportação, visto que é composto por receitas orçamentárias. Esta seria uma característica diferenciadora dos demais fundos soberanos ao redor do mundo.

\subsubsection{PRINCIPAIS FUNDOS CONSTITUCIONAIS DE RECURSOS VINCULADOS}

Nos fundos de recursos vinculados, em sua constituição pode ocorrer a transferência condicionada de verbas à consecução de determinada finalidade preestabelecida. Incluem-se, nesta categoria, os fundos constitucionais previstos para escopo específico, além da possibilidade de criação, mediante lei, de novos fundos, nos ditames do estabelecido no artigo 165, § 9º II, da Constituição da República. In casu explica JOSÉ MAURICIO CONTI ${ }^{772}$-, a Lei no $4.320 / 64$ foi recepcionada como a lei complementar em referência, cujos dispositivos (artigos 71 a 74) tratam sobre o estabelecimento de novos fundos. Este entendimento está, inclusive, consolidado pelo sodalício supremo da nação ${ }^{773}$.

\footnotetext{
${ }^{771}$ Pleno. j. 31 ago. 1994. DJU. 25 mai. 2001.

${ }^{772}$ Federalismo..., p. 76-77.

${ }^{773}$ ADI-MC 1.726-5/DF. Pleno. Rel. Min. Maurício Corrêa. j. 16 set. 1998. DJU 30 abr. 2004. "EMENTA: MEDIDA CAUTELAR EM AÇÃO DIRETA DE INCONSTITUCIONALIDADE. MEDIDA PROVISÓRIA $\mathrm{N}^{\circ}$ 1.061, DE 11.11.97 (LEI No 9.531, DE 10.12.97), QUE CRIA O FUNDO DE GARANTIA PARA PROMOÇÃO DA COMPETIVIDADE - FGPC. ALEGADA VIOLAÇÃO DOS ARTS. 62 E PAR. ÚNICO, 165, II, III, §§ $5^{\circ}$, I E III, E $9^{\circ}$, E 167, II E IX, DA CONSTITUIÇÃO. 1. A exigência de previa lei complementar estabelecendo condições gerais para a instituição de fundos, como exige o art. 165 , § $9^{\circ}$, II, da Constituição, está suprida pela Lei $\mathrm{n}^{\circ}$ 4.320, de 17.3.64, recepcionada pela Constituição com status de lei complementar; embora a Constituição não se refira aos fundos especiais, estão eles disciplinados nos arts. 71 a 74 desta Lei, que se aplica à espécie (...)."
} 
A maioria dos fundos constitucionais almeja destinar recursos a objetivos sociais. EWAN Clague e JOEL GORDON ${ }^{774}$ demonstram que este tipo de vinculação de receitas para viabilização de fins sociais possui duas facetas: em épocas de alta na economia e nos recursos públicos, os fundos terão os montantes necessários para o seu custeio; contudo, em crises na arrecadação, haveria um enorme problema de insuficiência para o financiamento dos custos já gerados, uma vez que, ao menos teoricamente, não teria como o fundo obter recursos de outras fontes que não por meio das previamente vinculadas. Outro ponto é que eles provocariam o desenvolvimento desigual de uma política social em detrimento de outras, à proporção que diminuem os recursos gerais do orçamento e não estão suscetíveis às contenções que os governos promovem para reduzir despesas nestas épocas mais críticas.

A fim de delinear brevemente estes tipos de fundos, serão mencionados a seguir os principais fundos de recursos afetados previstos constitucionalmente, excluídos aqueles destinados ao federalismo fiscal.

\subsubsection{FUNDO DE COMBATE E ERRADICAÇÃO DA POBREZA FEDERAL}

Com o advento da Emenda Constitucional n 31, de 2000, houve a instituição do Fundo de Combate e Erradicação da Pobreza. Sua finalidade - conforme consta no caput do artigo 79 do ADCT - é:

Art. 79. É instituído, para vigorar até o ano de 2010, no âmbito do Poder Executivo Federal, o Fundo de Combate e Erradicação da Pobreza, a ser regulado por lei complementar com o objetivo de viabilizar a todos os brasileiros acesso a níveis dignos de subsistência, cujos recursos serão aplicados em ações suplementares de nutrição, habitação, educação, saúde, reforço de renda familiar e outros programas de relevante interesse social voltados para melhoria da qualidade de vida.

Parágrafo único. O Fundo previsto neste artigo terá Conselho Consultivo e de Acompanhamento que conte com a participação de representantes da sociedade civil, nos termos da lei. (destacou-se)

MARCOS ANDRÉ VinHAS CATÃo ${ }^{775}$ entende tratar-se de uma mitigação, por via indireta, da regra da não afetação, muito embora ressalve que não seria uma forma tão cristalina de exceção ao referido princípio; porém, à moda do direito americano, o

\footnotetext{
${ }^{774}$ Earmarking..., p. 13-14.

${ }^{775}$ Novas..., p. 575. Cf., na mesma linha, CAMPOS, Dejalma de. Direito financeiro e orçamentário. 4. ed. São Paulo: Atlas, 2006, p. 58.
} 
ordenamento pátrio vale-se da utilização de fundos para mitigar o princípio, principalmente para destinar recursos a políticas sociais. RICARDO LOBO TORRES ${ }^{776}$ classifica o Fundo como uma vinculação de recursos públicos à garantia do mínimo existencial, que, em tese, já estariam alocados pelo orçamento, constituindo-se em um retrocesso orçamentário.

Destacadas estas considerações, faz-se mister mencionar que o artigo 80 do ADCT promove a vinculação das seguintes receitas, a saber:

a) a parcela do produto da arrecadação correspondente a um adicional de 0,08\%, de 18 de junho de 2000 a 17 de junho de 2002, na alíquota da extinta CPMF - prevista no artigo 75 do ADCT;

b) a parcela do produto da arrecadação correspondente a um adicional de $5 \%$ na alíquota do IPI, incidente sobre produtos supérfluos;

c) a arrecadação do Imposto sobre Grandes Fortunas (IGF) - se um dia vier a ser exercida esta competência pela União Federal;

d) dotações orçamentárias não especificadas;

e) doações;

f) outras receitas, definidas na regulamentação do Fundo (Lei Complementar $\left.n^{\circ} 111 / 2001\right)$.

$\mathrm{O}$ artigo 81 do ADCT acrescenta ainda, às receitas do Fundo, os recursos provenientes da desestatização das empresas da União Federal.

É interessante notar que o parágrafo primeiro do mencionado artigo 80 do ADCT excetua textualmente a regra geral da não vinculação de impostos prevista no artigo 167, IV, da Constituição Federal no tocante aos recursos que compõe o Fundo. Ocorre que o artigo 80 do ADCT já faz a menção ao IPI e ao IGF, vinculando as suas respectivas receitas no percentual de $5 \%$ e $100 \%$, respectivamente. Tal referência, portanto, em tese seria desnecessária, já que, conforme exposto $^{777}$, a regra específica da afetação constitucional afasta a aplicação do princípio da não afetação no ordenamento brasileiro, mitigando-o.

\footnotetext{
${ }^{776}$ Tratado..., p. 343. O núcleo intangível constitucional conhecido como mínimo existencial (minimum threshold; umbral mínimo; limiar mínimo; piso vital), em nossa opinião, está garantido exaustivamente pela Constituição Federal nos artigos $5^{\circ}$ e $7^{\circ}$, dentre outros atuando de forma complementar. Porém, como o texto constitucional é analítico e prevê diversos direitos que se pressupõem mínimos, difícil é estabelecer as prioridades, o que dificulta a atividade do legislador orçamentário.

${ }^{777}$ Ver item 3.3.2 supra.
} 
A dúvida cingir-se-ia aos casos de utilização de recursos de outros impostos para a composição do fundo, conforme permite o inciso VI ao consignar a expressão "outras receitas”. Percebe-se que a abrangência de tal regra poderia, e. g., permitir a vinculação total de um imposto - ressalvadas, obviamente, as demais vinculações constitucionais - a este Fundo, de forma que a integridade da receita de um imposto ficasse vinculada por norma infraconstitucional (in casu, lei complementar) a despesas específicas.

Interpretação deste jaez só conduziria a uma afronta ao princípio da não afetação das receitas de impostos, conforme prevê o artigo 167, IV, da Constituição Federal. Neste caso, não há outra forma de interpretar a permissão senão no sentido de que as demais receitas que poderiam ser vinculadas seriam a de outros tributos que não os impostos além das receitas não tributárias, também passíveis de vinculações -, sob pena de evidente inconstitucionalidade.

Obtemperamos que, por se tratar de regra constitucional, somente outra norma constitucional específica pode vincular a receita de impostos ${ }^{778}$, sob o risco de se desnaturar a própria característica desta espécie tributária - que é a de custear os serviços públicos gerais, sendo alheia a qualquer atuação estatal específica, conforme ensinamento de Paulo de Barros Carvalho ${ }^{779}$. A lei complementar não tem, diante disto, o condão de excepcionar o artigo 167, IV, da Constituição.

Destarte, a exceção prevista no artigo $80, \S 1^{\circ}$ do ADCT com relação aos impostos limita-se tão somente quanto ao IPI e ao IGF. O próprio dispositivo menciona a não aplicação, neste Fundo, da repartição de receitas tributárias no federalismo, em clara consonância ao que ocorre com o IPI nas transferências promovidas pela União Federal. A preocupação, neste comando legal, foi a de garantir a constitucionalidade da consignação das receitas destes impostos, de forma que outros só poderiam ser vinculados via emenda constitucional ad hoc.

\footnotetext{
${ }^{778}$ Este é o sentido da uma decisão judicial na análise de vinculação por lei estadual de receitas municipais: "Lei estadual que determina que os municípios deverão aplicar, diretamente, nas áreas indígenas localizadas em seus respectivos territórios, parcela $(50 \%)$ do ICMS a eles distribuída - transgressão à cláusula constitucional da não-afetação da receita oriunda de impostos (cf, art. 167, IV) e ao postulado da autonomia municipal (cf, art. 30, III) - vedação constitucional que impede, ressalvadas as exceções previstas na própria constituição, a vinculação, a órgão, fundo ou despesa, do produto da arrecadação de impostos - inviabilidade de o estado-membro impor, ao município, a destinação de recursos e rendas que a este pertencem por direito próprio - ingerência estadual indevida em tema de exclusivo interesse do município - (...)" (destacou-se). Supremo Tribunal Federal. ADI-MC 2.355-1/PR. Pleno. Rel. Min. Celso de Mello. j. 19 jun. 2002. DJU 29 jun. 2007.

${ }_{779}$ Curso..., p. 36. O autor ressalta a importância, para a ciência das finanças, das lições que explicam que o produto da arrecadação estatal seja destinado às despesas gerais do Estado, porém, sendo tal cogitação irrelevante para a ciência tributária.
} 
Em suma, nas “demais receitas" previstas no inciso VI do artigo 80 do ADCT não se incluiriam aquelas oriundas dos demais impostos, sob pena de desafiar o princípio da não afetação de impostos inscrito constitucionalmente que deve vir ressalvado de forma expressa $^{780}$. Isto leva à conclusão de que a inserção deste dispositivo no artigo é desnecessária, conforme se verá em seguida na análise comparada com os Fundos Estaduais e Distritais.

Outra restrição terminativa é quanto à proibição de aplicação de qualquer dispositivo desvinculatório de receitas ao Fundo, o que ficou consignado expressamente no parágrafo primeiro, in fine, do artigo 80 do ADCT.

\subsubsection{FUNDOS DE COMBATE À POBREZA ESTADUAIS, DISTRITAL OU MUNICIPAIS}

Analogamente ao Fundo de Combate e Erradicação da Pobreza da União Federal, a Carta Magna estabelece Fundos de Combate à Pobreza estaduais, distrital ou municipais, previstos no artigo 82 do ADCT. Apesar de não textualmente especificados, os seus escopos devem ser considerados igualmente àqueles do Fundo de Combate e Erradicação da Pobreza da União. Neste caso, porém, há a particularidade da obrigação de se ter, como gestoras dos fundos, entidades que contem com a participação da sociedade.

O custeio dos referidos fundos dar-se-á, nos termos do artigo 82 do ADCT, pelas seguintes receitas e com outros recursos que venham a ser destinados:

a) possibilidade de acréscimo de $2 \%$ na alíquota do ICMS sobre os produtos e serviços supérfluos assim definidos em lei complementar;

b) no caso dos Municípios, a possibilidade de acréscimo de 0,5\% na alíquota do ISS sobre serviços supérfluos, definido em lei.

\footnotetext{
${ }^{780}$ A vedação deve ser afastada de forma expressa, conforme já decidiu o Supremo Tribunal Federal na ADI 1.689-2/PE. Pleno. Rel. Min. Sydney Sanches j. 12 mar. 2003. DJU 2 mai. 2003: "DIREITO CONSTITUCIONAL. LEI ORÇAMENTÁRIA: INICIATIVA. VINCULAÇÃO DE RECEITA. AUTONOMIA MUNICIPAL. ASSISTÊNCIA À CRIANÇA E AO ADOLESCENTE. AÇÃO DIRETA DE INCONSTITUCIONALIDADE DO PARÁGRAFO ÚNICO DO ART. 227 DA CONSTITUIÇÃO DO ESTADO DE PERNAMBUCO, QUE DISPÕEM: (...) A vedação é afastada, portanto, apenas nas hipóteses expressamente ressalvadas, que não abrangem os programas de assistência integral à criança e ao adolescente. É que, quanto a isso, o inciso IV do art. 167 da Constituição Federal encerra norma específica, fazendo ressalva expressa apenas das hipóteses tratadas nos artigos 198, § $2^{\circ}$ (Sistema Único de Saúde) e 212 (para manutenção e desenvolvimento do ensino) (...).” (destacou-se)
} 
Ressalve-se que, no estabelecimento constitucional das diretrizes pertinentes a este Fundo, não há nenhuma ressalva textual quanto à vedação de aplicação do princípio da não vinculação das receitas de impostos - como é feito no Fundo Federal. Desta forma, deve-se fazer uma intelecção das vinculações da mesma forma como realizada no item anterior: dado que se trata de uma exceção constitucional específica à regra, não há óbices para que seja feita a vinculação de receitas somente dos impostos evidentemente destacados.

In casu, o próprio legislador, atento à desnecessidade da ressalva, não inscreveu no texto legal a não aplicação da regra da não afetação de impostos, tendo em vista que a referida afetação é realizada via norma constitucional. Neste ponto - é possível cogitar -, visto que (i) para os Fundos estaduais, distrital e municipais de Combate à Pobreza não houve a expressa menção constitucional a fim de não haver a aplicação da vedação de vinculação de receita de impostos (como há no caso do Fundo da União), e (ii) concebendo-se o ordenamento de forma sistemática (interpretação sistemática ${ }^{781}$ ), o legislador, no caso dos Fundos Federais, permitiria a vinculação da receita dos demais impostos que não os previstos constitucionalmente para este fim (IPI e IGF).

Porém, conforme exposto anteriormente, a exceção quanto ao princípio da não vinculação deve ser taxativa, de forma que, havendo a prévia delimitação dos impostos que comporão o Fundo, deve-se interpretar tal rol como exaustivo, sendo incabíveis quaisquer incursões quanto à vinculação de receitas de outros impostos.

Desta feita, reforça-se como dispensável a previsão de exceção ao princípio da não afetação no Fundo de Combate e Erradicação da Pobreza Federal, dado que outros tributos já poderiam ser automaticamente vinculados e, no tocante à vinculação dos impostos, deve haver a consignação mediante Emenda Constitucional.

\subsubsection{FUNDOS ESTADUAIS E DISTRITAL DE FOMENTO À CULTURA}

Iniciativas de criação de fundos voltados ao fomento da cultura são corriqueiras na prática orçamentária dos Estados modernos. Na Argentina, a doutrina expõe que a Ley

${ }^{781}$ Cf. Ferraz JúnIOR, Tércio Sampaio. Introdução ao Estudo do Direito. 4. ed. São Paulo: Atlas, 2003, p. 288-89 e também BECKER, Alfredo Augusto, Teoria..., p. 105. A sistemática advém da concepção de que não há normas isoladas no ordenamento: cada uma deve ser analisada como resultado de um feixe de influências de outras normas. 
24.800/1997 criou o Fundo Nacional do Teatro, afetando 8\% do total das rendas arrecadadas pelo Comitê Federal de Radiodifusão e destinando-as ao Instituto Nacional do Teatro. In casu, utiliza-se um sistema complexo de transferência automática de um percentual específico de uma receita, estabelecendo diretrizes de como deve ser feita a distribuição destes recursos ${ }^{782}$.

Domesticamente, a Emenda Constitucional $n^{\circ} 42$, de 2003, inseriu o $\S 6^{\circ}$ no artigo 216, da Constituição Federal, que faculta aos Estados e ao Distrito Federal a utilização de até $0,5 \%$ de suas receitas tributárias líquidas para fundos de financiamento de programas e projetos culturais, porém, com certas limitações de uso deste fundo. É interessante notar que o inciso III ressalva a não permissão de aplicação dos recursos destinados a "qualquer outra despesa corrente não vinculada diretamente aos investimentos ou ações apoiados."

Nunca é demais recordar que as despesas estatais são subdivididas em correntes e de capital, nos termos do artigo 11 da Lei $\mathrm{n}^{\circ}$ 4.320/64. No artigo 12, as despesas de capital são subdivididas em outras três, dentre as quais está a de investimentos, cujo delineamento é previsto no parágrafo quarto deste mesmo artigo ${ }^{783}$.

Dada a superfluidade do legislador neste ponto, dir-se-ia - apenas para fins argumentativos - que, a contrario sensu, haveria a permissão de uso destas receitas para a assunção de despesas de capital não vinculadas aos investimentos correlatos à cultura, o que, a rigor, seria um despautério jurídico. Prescindível, destarte, esta menção, visto que as despesas só poderiam ser satisfeitas se vinculadas ao escopo de criação do fundo.

É imanente a toda vinculação a relação entre meios e fins, que não pode ser quebrada pelo administrador público senão mediante norma específica que se sobreponha à norma vinculatória, sob pena de desnaturação do próprio instituto da vinculação de receitas. Logo, seria óbvio concluir que as receitas destinadas ao Fundo de Fomento à Cultura só podem ser para despesas (correntes ou de capital) com cultura.

Diante disto, qual a razão da inserção no sentido de que não pode haver a destinação a despesa corrente não vinculada? O excesso de rigor mais prejudicou do que clarificou, de forma que tais positivações devem ser vistas cum grano salis. Bastaria a omissão quanto ao assunto, tendo em consideração que é uma intelecção automática e racional do instituto da vinculação de receitas no sentido de haver o estabelecimento de elo ou ligação indissociável entre a vinculação gerada e o fim colimado.

\footnotetext{
${ }^{782}$ Cf. CORTI, Horacio Guillermo. Derecho..., p. 313.

${ }^{783}$ Lembra REgIS FERNANDES DE OLIVEIRA (Curso..., p. 255) que as despesas devem ser adequadas e respeitarem a respectiva dotação orçamentária, compatibilizada com o plano plurianual e a lei de diretrizes orçamentárias, nos termos do artigo $16, \S 1^{\circ}$, I e II da LRF.
} 
Em suma, não poderia haver, em hipótese alguma, vinculação a despesa (corrente ou de capital) que não fosse correlata, seja direta ou indiretamente, ao escopo por que foi criada, razão pela qual houve certo pecado do legislador no excesso dos dizeres inscritos nesta regra. Ou, então, talvez estivesse receoso das constantes práticas de desvio das vinculações às quais o orçamento público assujeita-se, de forma que sua temperança mereceria louvor neste sentido.

\subsubsection{FUNDO DE MANUTENÇAO E DESENVOLVIMENTO DA EDUCAÇÃO BÁSICA E DE VALORIZAÇÃOO DOS PROFISSIONAIS DA EDUCAÇÃO - FUNDEB}

Fundos de incentivo à docência costumam ser propostos pelas nações a fim de sanarem as naturais falhas no setor educacional, normalmente relegado ao segundo plano nos países em desenvolvimento. Na Argentina, recentemente (Leyes $\mathrm{n}^{\circ}$ 25.053/1998, 25.239/1999 e 25.264/2000) houve a criação do Fundo Nacional de Incentivo Docente por meio de um imposto de emergência anual sobre a propriedade de veículos ${ }^{784}$.

No direito pátrio, a Lei Federal n ${ }^{\circ}$ 9.424/1996 estatuiu o Fundo de Manutenção e Desenvolvimento do Ensino Fundamental e de Valorização do Magistério - FUNDEF, com fulcro na Emenda Complementar no 14, de 1996. A Emenda Constitucional no 53, de 2006, permitindo que as disposições concernentes ao FUNDEF fossem revogadas pela Lei n 11.494/2007, instituiu o Fundo de Manutenção e Desenvolvimento da Educação Básica e de Valorização dos Profissionais da Educação - FUNDEB, a ser criado em cada Estado e no Distrito Federal. Esta é a prescrição do artigo 60 do ADCT, regulamentado inicialmente

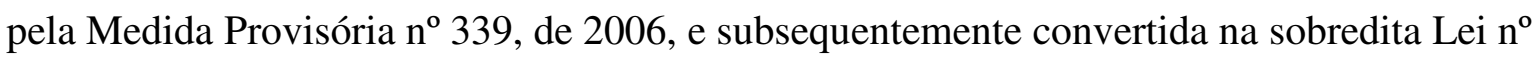
11.494/07.

Conforme dicção do inciso II do artigo 60 do ADCT, para a sua constituição instituiu-se a vinculação na razão de $20 \%$ :

a) dos recursos do ITCMD, ICMS e IPVA;

b) do produto da arrecadação destinada aos Estados no tocante aos impostos residuais da União (id est, 20\%);

${ }^{784}$ Cf. CoRTI, Horacio Guillermo. Derecho..., p. 314. 
c) da repartição e partilha das receitas tributárias, no que tange ao ITR, IPVA e ICMS;

d) da parcela do produto da arrecadação do IR e IPI destinada ao FPE e FPM;

e) dos $10 \%$ do IPI-exportação que são cabíveis aos Estados (e ao Distrito Federal) de origem.

O repasse aos Estados e seus Municípios será feito de forma proporcional ao número de alunos matriculados na educação básica, sitos nos seus respectivos territórios.

A União Federal também participará do FUNDEB, complementando-o em caso do valor por aluno não chegar ao mínimo definido nacionalmente em uma escala anual, atingindo, a partir do quarto ano de vigência, $10 \%$ do montante dos recursos definidos no inciso II do mesmo artigo delineado supra. Há também uma meta percentual a ser atingida, gradativamente, nos três primeiros anos de vigência dos Fundos, qual seja:

\begin{tabular}{|l|l|l|l|}
\cline { 2 - 4 } \multicolumn{1}{c|}{} & Primeiro ano & Segundo Ano & Terceiro Ano \\
\hline ICMS & $16,66 \%$ & $18,33 \%$ & $20 \%$ \\
\hline Transferência do ICMS ao Município & $16,66 \%$ & $18,33 \%$ & $20 \%$ \\
\hline $\begin{array}{l}\text { Transferência do IPI e do IR ao FPE e } \\
\text { FPM }\end{array}$ & $16,66 \%$ & $18,33 \%$ & $20 \%$ \\
\hline $\begin{array}{l}\text { Transferência aos Estados de origem do } \\
\text { IPI-Exportação }\end{array}$ & $16,66 \%$ & $18,33 \%$ & $20 \%$ \\
\hline ITCMD e IPVA & $6,66 \%$ & $13,33 \%$ & $20 \%$ \\
\hline $\begin{array}{l}\text { Transferências oriundas de impostos } \\
\text { residuais aos Estados }\end{array}$ & $6,66 \%$ & $13,33 \%$ & $20 \%$ \\
\hline $\begin{array}{l}\text { Transferências do ITR e IPVA aos } \\
\text { Municípios }\end{array}$ & $6,66 \%$ & $13,33 \%$ & $20 \%$ \\
\hline
\end{tabular}

Tabela 2: Metas a serem atingidas nos três primeiros anos de vigência do FUNDEB.

Este fundo é utilizado como mecanismo de repartição de competências e receitas para a educação na sistemática do federalismo fiscal brasileiro. Conforme expõe WELLINGTON FERREIRA DE JESUS ${ }^{785}$, a "vinculação" para a educação historicamente assumiu importante papel pioneiro com a Constituição de 1934, cujo escopo era justamente delimitar a atuação de cada ente federativo nesta seara. Após, com o Estado Novo, houve uma contenção nesta modalidade de financiamento da educação, voltando posteriormente no texto constitucional de 1946.

785 "Despesa sagrada”: estudo sobre a vinculação constitucional de verbas para a educação nas Constituições Brasileiras de 1934 e 1946. Dissertação (Mestrado em Educação) - Universidade Católica de Brasília, 2007, p. 22 e ss. 


\title{
4.1.3. PRINCIPAIS FUNDOS INFRACONSTITUCIONAIS
}

\subsubsection{FUNDO PENITENCIÁRIO NACIONAL - FUNPEN}

A Lei Complementar $n^{\circ} 79 / 94$ instituiu o Fundo Penitenciário Nacional FUNPEN, cujas atribuições cingem-se aos financiamentos e apoios com recursos para a modernização e aprimoramento do Sistema Penitenciário Nacional.

$\mathrm{O}$ artigo $2^{\circ}$ da supracitada lei dispõe que:

\begin{abstract}
Art. $2^{\circ}$ Constituirão recursos do Funpen:
I - dotações orçamentárias da União;

II - doações, contribuições em dinheiro, valores, bens móveis e imóveis, que venha a receber de organismos ou entidades nacionais, internacionais ou estrangeiras, bem como de pessoas físicas e jurídicas, nacionais ou estrangeiras;

III - recursos provenientes de convênios, contratos ou acordos firmados com entidades públicas ou privadas, nacionais, internacionais ou estrangeiras;

IV - recursos confiscados ou provenientes da alienação dos bens perdidos em favor da União Federal, nos termos da legislação penal ou processual penal, excluindo-se aqueles já destinados ao fundo de que trata a Lei no 7.560, de 19 de dezembro de 1986;

V - multas decorrentes de sentenças penais condenatórias com trânsito em julgado;

VI - fianças quebradas ou perdidas, em conformidade com o disposto na lei processual penal;

VII - cinqüenta por cento do montante total das custas judiciais recolhidas em favor da União Federal, relativas aos seus serviços forenses;

VIII - três por cento do montante arrecadado dos concursos de prognósticos, sorteios e loterias, no âmbito do Governo Federal;

IX - rendimentos de qualquer natureza, auferidos como remuneração, decorrentes de aplicação do patrimônio do Funpen;

$\mathrm{X}$ - outros recursos que lhe forem destinados por lei. (destacou-se)
\end{abstract}

Percebe-se que o referido Fundo sustenta-se, sobretudo, com receitas oriundas da atividade de persecução penal do Estado (multa, fiança, confisco e perdimento de bens e valores). Entretanto, há, respectivamente, nos incisos VII e VIII, a vinculação de percentual das receitas das custas judiciais recolhidas em favor da União Federal (taxas judiciárias) relativas aos seus serviços forenses e dos concursos de prognósticos, sorteios e loterias do Governo Federal $^{786}$.

\footnotetext{
786 Outros diplomas normativos estabelecem vinculações da receita dos concursos de prognósticos para atividades específicas. O Decreto-lei n ${ }^{\circ}$ 204, de 27 de fevereiro de 1967, prevê, em seu artigo 27, a criação de um Fundo Especial da Loteria Federal para alguns objetivos específicos delineados no artigo 28 do mesmo diploma. Já a Lei no 10.264, de 16 de julho de 2001 ("Lei Pelé”), prevê o repasse de percentual da arrecadação nas loterias às atividades desportivas.
} 
Desta forma, nada impede que a lei venha a vincular outras receitas, a despeito da recomendação de LUIZ PINTO FERREIRA ${ }^{787}$ de que consistiria em péssima prática financeira tal conduta. Poder-se-ia contestar, além disso, se a vinculação de taxa a fins diversos do previsto quando da sua instituição (custeio de serviços públicos específicos e indivisíveis) feriria a vinculação das taxas ao propósito de sua criação. Entendemos que deve haver certa correlação mínima com o serviço público que ensejou a sua instituição. O Supremo Tribunal Federal, no julgamento da Ação Direta de Inconstitucionalidade no 3.643-2/RJ, decidiu ser constitucional a vinculação da taxa de emolumentos extrajudiciais a Fundo destinado à Defensoria Pública do Estado, sob o argumento de que a atividade é afeta a serviço conectado à estrutura e funcionamento de sistema essencial à função jurisdicional, além de efetivar a universalização da justiça, conforme o artigo $5^{\circ}, \mathrm{XXXV}$, da Constituição Federal $^{788}$.

Segundo a Suprema Corte, a vedação contida no artigo 167, IV, da Constituição Federal não se aplica às taxas, recaindo tão somente aos impostos, que é a interpretação adequada que se pode exarar do instituto vedatório, conforme sobredito ${ }^{789}$. Poderia, destarte, ocorrer a vinculação da taxa a Fundo específico, a menos que respeitado o vínculo original de sua criação, ainda que remotamente. Este também foi o entendimento do Ministro Eros Grau na relatoria da Ação Direta de Inconstitucionalidade n ${ }^{\circ}$ 2.059/PR ${ }^{790}$.

Considerando que (i) seria possível uma taxa ser consignada a um fundo especial, e (ii) a taxa de custeio de serviço público deve ser afetada à sua origem ainda que remotamente, a saber, o próprio serviço prestado, a vinculação da taxa judiciária ao serviço penitenciário detém, mesmo que de forma longínqua, um elo entre a sua instituição e a prestação do serviço estatal, ainda que a Poder diverso do Judiciário. A execução penal é fase que se dá, mormente, no sistema carcerário, de forma que o custeio destas despesas poderia ser vinculado à taxa judiciária em tela.

\footnotetext{
${ }^{787}$ Comentários à Constituição Brasileira. 6. v. São Paulo: Saraiva, 1994, p. 115.

${ }^{788}$ Pleno. Rel. Min. Carlos Britto. j. 8 nov. 2006. DJU 16 fev. 2007: "CONSTITUCIONAL. AÇÃO DIRETA DE INCONSTITUCIONALIDADE. INCISO III DO ART. $4^{\circ}$ DA LEI No 4.664, DE 14 DE DEZEMBRO DE 2005, DO ESTADO DO RIO DE JANEIRO. TAXA INSTITUÍDA SOBRE AS ATIVIDADES NOTARIAIS E DE REGISTRO. PRODUTO DA ARRECADAÇÃO DESTINADO AO FUNDO ESPECIAL DA DEFENSORIA PÚBLICA DO ESTADO DO RIO DE JANEIRO. É constitucional a destinação do produto da arrecadação da taxa de polícia sobre as atividades notariais e de registro, ora para tonificar a musculatura econômica desse ou daquele órgão do Poder Judiciário, ora para aportar recursos financeiros para a jurisdição em si mesma. O inciso IV do art. 167 da Constituição passa ao largo do instituto da taxa, recaindo, isto sim, sobre qualquer modalidade de imposto (...)."

789 Ver item 3.2 supra.

${ }^{790}$ Pleno. j. 26 abr. 2006. DJU 9 jun. 2006.
} 
Este elo mínimo é necessário para que não haja uma fuga conceitual da natureza jurídica da taxa. A taxa, no entender de JOSÉ MARTINHO SIMÕES ${ }^{791}$, é uma personalização jurídica dos serviços públicos, sendo uma vinculação de receitas em sua expressão máxima, de forma que deve haver a correlação entre a taxa e o serviço, sob pena de imposto disfarçado. No nosso entender, é este elo ou pertinência mínima entre a exação e o serviço prestado que garante a possibilidade de instituição de uma taxa, e não imposto.

Desta forma, o que não pode haver é uma taxa para custear serviços gerais totalmente alheios à razão da criação do tributo, sob o risco de descaracterizá-lo como taxa, transmutando-o, em essência, em um imposto. É como determinado ente federativo cobrar uma taxa sobre a iluminação pública e vincular estas verbas à educação ou saúde: não há qualquer liame entre a taxa e o serviço prestado; consistiria, em verdade, em um imposto sobre a iluminação pública.

\subsubsection{FUNDO ESPECIAL DE ASSISTÊNCIA FINANCEIRA AOS PARTIDOS POLÍTICOS (FUNDO PARTIDÁRIO)}

A vinculação de receitas pode ser importante instrumento a fim de garantir os desideratos democráticos, garantindo que o processo político encete-se por meio de verbas públicas, ao menos parcialmente, dado que as doações podem ir para um fundo único - e não a um partido em especial. Concede-se, então, maior isonomia nas eleições e menor "captura" dos eleitores por grupos de interesse.

A Lei no 9.096/1995, ao disciplinar acerca dos partidos políticos, dispõe, no artigo 38, quanto às finanças partidárias. Criou-se, por meio de um Fundo Partidário (Fundo Especial de Assistência Financeira aos Partidos Políticos), a vinculação de receitas necessárias para preservar esta relação isonômica que deve haver entre os partidos nas campanhas para as eleições.

Este sistema é decalcado na sistemática italiana; todavia, na península itálica há a possibilidade de vinculação pelos contribuintes, no ato de recolhimento dos impostos, de parcela a ser destinada ao custeio público dos partidos políticos. O subsídio público também aparece na Bélgica, Espanha, França, Alemanha, Suécia e Portugal ${ }^{792}$, bem como

\footnotetext{
${ }^{791}$ Finanças..., p. 650.

792 Cf. CASSEB, Paulo Adib. Financiamento partidário: sistema público ou privado? IOB-Repertório de Jurisprudência. São Paulo. n.13, 2002, p. 506-07.
} 
na recente Constituição equatoriana ${ }^{793}$. Além da campanha, há disposições que destinam verbas ao funcionamento dos tribunais eleitorais: no Chile, a Constituição prevê que exista uma quantia obrigatória fixada na lei orçamentária, necessária ao funcionamento destes tribunais $^{794}$.

Os excertos que interessam, no âmbito deste trabalho, são os relativos aos incisos II e IV do mencionado artigo. O inciso II permite a destinação de recursos financeiros por lei, podendo ser em caráter permanente ou eventual. Já o inciso IV relaciona as dotações orçamentárias da União ao número de eleitores multiplicado por uma quantia fixa, o que pode importar a necessidade de busca por receitas acessórias se houver aumento significativo neste número de votantes. Por fim, a indispensabilidade de controle quanto às verbas oriundas deste Fundo fez com que houvesse, consequentemente, a vinculação das receitas a despesas predeterminadas, conforme insculpido no artigo 44 do mesmo $\operatorname{diploma}^{795}$.

\subsubsection{FUNDO DE UNIVERSALIZAÇÃO DOS SERVIÇOS DE TELECOMUNICAÇÕES - FUST E FUNDO PARA O DESENVOLVIMENTO TECNOLÓGICO DAS TELECOMUNICAÇÕES - FUNTTEL}

A Lei $n^{\circ}$ 9.998/2000 instituiu o Fundo de Universalização dos Serviços de Telecomunicações - FUST, cujo escopo é viabilizar recursos destinados à cobertura de parcela de custo atribuível às obrigações de universalização de serviços de

\footnotetext{
${ }^{793}$ Artículo 110: Los partidos y movimientos políticos se financiarán con los aportes de sus afiliadas, afiliados y simpatizantes, y en la medida en que cumplan con los requisitos que establezca la ley, los partidos políticos recibirán asignaciones del Estado sujetas a control.

El movimiento político que en dos elecciones pluripersonales sucesivas obtenga al menos el cinco por ciento de votos válidos a nivel nacional, adquirirá iguales derechos y deberá cumplir las mismas obligaciones que los partidos políticos.

${ }^{794}$ Artículo 97. Anualmente, se destinarán en la Ley de Presupuestos de la Nación los fondos necesarios para la organización y funcionamiento de estos tribunales, cuyas plantas, remuneraciones y estatuto del personal serán establecidos por ley.

${ }^{795}$ Art. 44. Os recursos oriundos do Fundo Partidário serão aplicados:

I - na manutenção das sedes e serviços do partido, permitido o pagamento de pessoal, a qualquer título, observado neste último caso o limite máximo de 50\% (cinquenta por cento) do total recebido;

II - na propaganda doutrinária e política;

III - no alistamento e campanhas eleitorais;

IV - na criação e manutenção de instituto ou fundação de pesquisa e de doutrinação e educação política, sendo esta aplicação de, no mínimo, vinte por cento do total recebido.

V - na criação e manutenção de programas de promoção e difusão da participação política das mulheres conforme percentual que será fixado pelo órgão nacional de direção partidária, observado o mínimo de 5\% (cinco por cento) do total.
}

(...) 
telecomunicações e que não possa ser recuperada com a exploração do serviço, conforme prescreve o artigo $1^{\circ}$ da mencionada lei.

Em seu artigo $6^{\circ}$, há o detalhamento das receitas que serão afetadas a este Fundo. Os casos de vinculação de receitas verificam-se na (i) destinação de $50 \%$ dos recursos oriundos das outorgas e explorações do serviço pelo Poder Concedente; (ii) totalidade das receitas do preço público cobrado pela Agência reguladora - ANATEL em virtude de transferência da concessão, permissão ou autorização; e (iii) contribuição de 1\% sobre a receita operacional bruta oriunda da exploração do serviço de telecomunicações - CIDE. O inciso VI do mesmo artigo prevê também a vinculação de outras receitas, ocasião esta que não poderá advir da receita de impostos - para não constituir escolho ao artigo 167, inciso IV da Constituição Federal, que deve ser interpretado de forma restritiva.

Já o Fundo para o Desenvolvimento Tecnológico das Telecomunicações FUNTTEL, concebido pela Lei $\mathrm{n}^{\mathrm{o}} 10.052 / 2000$, adveio com o desiderato de estimular o processo de inovação tecnológica, incentivar a capacitação de recursos humanos e a geração de empregos, e promover o acesso de pequenas e médias empresas a recursos de capital no ramo de telecomunicações, conforme relaciona seu artigo $1^{\circ}$.

É oportuno mencionar o disposto nos incisos III e IV do artigo $4^{\circ}$ da sobredita lei. O inciso III prevê a contribuição de $0,5 \%$ da receita bruta das empresas do ramo de telecomunicações - com algumas ressalvas para a determinação da base de cálculo - e o inciso IV reserva $1 \%$ sobre a arrecadação bruta de eventos participativos realizados por meio de ligações telefônicas.

Por derradeiro, cumpre apenas deixar registrado que, mais uma vez, a prolixidade do legislador contribuiu para a mixórdia conceitual da vinculação de receitas aos fundos. Se o próprio fundo já prevê, em seu artigo primeiro, as razões de sua criação, de nada serve a ressalva do caput do artigo $6^{\circ}$ da referida lei, a saber:

Art. $6^{\circ}$ Os recursos do Fundo serão aplicados exclusivamente no interesse do setor de telecomunicações.

Se já há a vinculação de receitas a este fundo, imprestável é a referida ressalva, tendo em vista que qualquer tredestinação das receitas a outro setor seria, naturalmente, violadora da lei. Causa estranheza conceber-se um fundo especial com aplicação dos recursos diversa do escopo previsto, sob pena de afronta ao artigo 71 de Lei $n^{\circ} 4.320 / 64$, de forma que a citada ressalva deve ser vista como mero preciosismo. 
Talvez - aí conjecturamos apenas com base em ilações políticas, e não jurídicas tal ressalva seja oriunda da praxe pátria em não se dar a devida atenção às obrigações orçamentárias legais e constitucionais expressas. Ou, então, em virtude das costumeiras tredestinações por meio de manobras jurídicas para que os comandos legais não sejam cumpridos conforme teleologicamente concebidos.

MAUricio Portugal Ribeiro e LUCAS NAVARro Prado ${ }^{796}$ expõem que o FUST, apesar de atualmente possuir reserva de alguns bilhões de reais, ainda não realizou as despesas em prol do setor de telecomunicações. Isto ocorre porque, na visão dos autores, a vinculação não obrigaria à realização imediata da despesa, mas tão somente ao seu custeio, conforme já debatido $^{797}$. O restante, portanto, vem servindo à formação de superávit primário pela União Federal.

\subsubsection{FUNDO NACIONAL DA CULTURA}

O Fundo Nacional da Cultura - FNC foi inicialmente previsto pela Lei $\mathrm{n}^{\circ}$ 7.505/1986 e ratificado pela Lei $n^{\circ} 8.313 / 1991$, que instituiu o Programa Nacional de Apoio à Cultura (PRONAC), cujo desiderato é captar recursos para a promoção de atividades culturais.

Os objetivos do FNC estão inscritos nos incisos do artigo $4^{\circ}$ da Lei ${ }^{\circ}$ 8.313/1991:

Art. $4^{\circ}$ Fica ratificado o Fundo de Promoção Cultural, criado pela Lei n ${ }^{\circ} 7.505$, de 2 de julho de 1986, que passará a denominar-se Fundo Nacional da Cultura (FNC), com o objetivo de captar e destinar recursos para projetos culturais compatíveis com as finalidades do Pronac e de:

I - estimular a distribuição regional eqüitativa dos recursos a serem aplicados na execução de projetos culturais e artísticos;

II - favorecer a visão interestadual, estimulando projetos que explorem propostas culturais conjuntas, de enfoque regional;

III - apoiar projetos dotados de conteúdo cultural que enfatizem o aperfeiçoamento profissional e artístico dos recursos humanos na área da cultura, a criatividade e a diversidade cultural brasileira;

IV - contribuir para a preservação e proteção do patrimônio cultural e histórico brasileiro;

V - favorecer projetos que atendam às necessidades da produção cultural e aos interesses da coletividade, aí considerados os níveis qualitativos e quantitativos de atendimentos às demandas culturais existentes, o caráter multiplicador dos projetos através de seus aspectos sócio-culturais e a priorização de projetos em áreas artísticas e culturais com menos possibilidade de desenvolvimento com recursos próprios.

\footnotetext{
796 Comentários..., p. 221-22.

${ }^{797}$ Ver item 2.2.2 supra.
} 
O FNC é financiado, sobretudo, pelas receitas da Contribuição para o Desenvolvimento da Indústria Cinematográfica Nacional - CONDECINE, instituída pela Medida Provisória $\mathrm{n}^{\mathrm{o}} 2.228-1$ em seu artigo 32. O artigo 34 prevê que toda a sua arrecadação seja destinada ao FNC, de forma a fomentar, conjuntamente com outros recursos, o Programa de Apoio ao Desenvolvimento do Cinema Brasileiro - PRODECINE, o Programa de Apoio ao Desenvolvimento do Audiovisual Brasileiro - PRODAV e o Programa de Apoio ao Desenvolvimento da Infra-Estrutura do Cinema e do Audiovisual PRÓ-INFRA.

\subsubsection{FUNDO DA MARINHA MERCANTE - FMM}

O Fundo da Marinha Mercante - FMM foi criado pela Lei $n^{\circ} 3.381 / 58$, servindo principalmente para destinar recursos para a renovação, ampliação e recuperação da frota mercante, bem como para incentivar a indústria da construção naval brasileira. De acordo com o artigo $2^{\circ}$ da Lei, o FMM é formado pelos seguintes recursos:

Art. 2 O Fundo da Marinha Mercante será constituído:

a) do produto da Taxa de Renovação da Marinha Mercante (art. $8^{\circ}$ ) arrecadada pelas emprêsas navegação estrangeiras, pelas de propriedade da União e também pelos armadores nacionais que operem navios estrangeiros afretados;

b) de $32 \%$ (trinta dois por cento) da receita da taxa de despacho aduaneiro criada pela Lei $\mathrm{n}^{\circ} 3.244$ de 14 de agôsto de 1957;

c) aos juros, comissões e outras receitas resultantes da aplicação dos recursos do próprio Fundo ou a execução desta lei;

d) das dotações orçamentárias que lhe forem atribuídas no Orçamento Geral da União;

e) das importâncias oriundas do cumprimento do disposto no art. $11, \S 5^{\circ}$ e no art. 15 , $\S$ $1^{\mathrm{o}}$;

f) dos saldos anuais porventura apurados pela Comissão de Marinha Mercante no desempenho de suas atribuições.

As receitas vinculadas são aquelas oriundas de taxas, conforme se depreende das alíneas "a" e "b". A alínea "d" apenas registra que as dotações orçamentárias anuais poderão destinar recursos ao FMM. Com relação aos demais dispositivos, tratam de outras receitas auferidas pela atividade naval.

Atualmente, o FMM ganhou expressão com o surgimento do Programa de Aceleração do Crescimento - PAC, tendo sido destinadas ingentes dotações orçamentárias em projetos da indústria naval. Com a expansão econômica experimentada recentemente no País - imperando por um escoamento mais fluido da produção brasileira e melhoria da 
infraestrutura portuária -, pode ser que o FMM venha a ganhar importância nos próximos anos.

\subsection{DESAFETAÇÃO DE RECEITAS PÚBLICAS}

\subsubsection{TENDÊNCIA DESVINCULATÓRIA ESTATAL DAS RECEITAS}

JAMES GIACOMONI ${ }^{798}$ explica que "recursos excessivamente vinculados são sinônimos de dificuldade, pois podem significar sobra em programas de menor importância e falta em outros de maior prioridade." Na realidade, a afetação excessiva de recursos públicos - à semelhança do deus romano Janus - possui duas facetas: a primeira é que a vinculação em demasia garante com que a alocação dos recursos não fique ao total alvedrio do gestor público, malversando-a de acordo com seus interesses em detrimento de setores viscerais da sociedade.

Todavia, o lado negativo é justamente o engessamento dos recursos públicos ${ }^{799}$, o que, dependendo do grau, pode levar a nação a uma hecatombe na sua administração financeira. Esta é justamente a crítica realidade brasileira: ao vincular cerca de $80 \%{ }^{800}$ do seu orçamento federal, o administrador público não tem margem de manobra, de forma que pode ser extremamente prejudicial a outros setores que também necessitam de investimentos, mas que não o recebem por não existirem recursos desvinculados suficientes. RICARDO LOBO TORRES ${ }^{801}$ expõe levantamento realizado por JOSÉ SERRA no sentido de que as receitas livres de gravame representariam, na verdade, 5,7\% do orçamento, ou 1,5 \% do PIB. Já FERNANDO SERTÃ MERESSI ${ }^{802}$ consigna que as chamadas receitas livres comporiam apenas $10 \%$ das rendas do Tesouro. Aqui, portanto, o lado da falta de flexibilidade no trade-off das vinculações resta sobressalente ${ }^{803}$.

\footnotetext{
798 Orçamento..., p. 75.

${ }^{799}$ Cf. CONTI, José Mauricio. Direito financeiro na Constituição de 1988. São Paulo: Oliveira Mendes, 1998, p. 103. Esta é a advertência do jurista, pois tal engessamento pode limitar a liberdade do administrador em aplicar o recurso nas áreas que mais interessam à sociedade em um determinado momento.

${ }^{800}$ Cf. BRASIL. SECRETARIA DE ORÇAMENTO FEDERAL. Vinculações de Receitas dos Orçamentos Fiscal e da Seguridade Social e o Poder Discricionário de Alocação dos Recursos do Governo Federal. v. I. n. 1. Brasília: Secretaria de Orçamento Federal - SOF, 2003, p. 7. Disponível em: < http://www.planejamento.gov.br/secretarias/upload/Arquivos/sof/publicacoes/vinculacoes_orcamentarias.pdf >. Acesso em: 9 fev. 2009.

${ }^{801}$ Tratado..., p. 338.

802 Macrodinâmica do orçamento. Brasília: [s.n], 2006, p. 28. Disponível em: $<$ http://www.assecor.org.br/v2/documentos/Macrodinamica_do_Orcamento.pdf> . Acesso em: 27 fev. 2009.

${ }^{803}$ Ver item 1.6.1 supra.
} 
No Brasil, é importante a menção de que as despesas, em sua maioria, quer são determinadas pelas receitas, quer pela própria natureza da despesa (no caso dos gastos obrigatórios). As despesas discricionárias acabam, segundo expressão do autor, "saindo por resíduo" de acordo com a fórmula descrita a seguir:

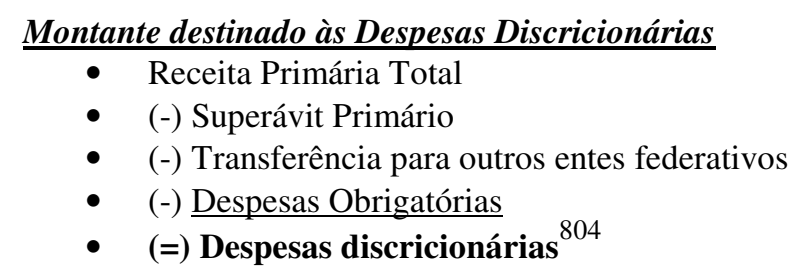

Com isto, a experiência retoma o passado, volvendo ao contexto do início do século nos Estados Unidos, como no caso do estado do Alabama - que chegou a vincular, em 1901, 90\% de suas receitas, cuja parcela maior era destinada, sobretudo, a programas voltados à educação e construção de rodovias. Porém, naquela época, o temor dos cidadãos era que o Legislativo desviasse as verbas públicas para outras searas supostamente consideradas mais necessárias pelos governantes ${ }^{805}$.

Em Portugal, em meados da década de setenta, o nível de vinculação estatal apesar de baixo - era de 10\%, cifra esta que deve ser analisada sob dois aspectos segundo a doutrina: pelo viés da importância ao se garantir as finalidades estatais e sob o arcaísmo financeiro de se manter tal instituto em um ordenamento que, cedo ou tarde, requereria a revisão das vinculações existentes ${ }^{806}$.

Esta revisão foi concebida também nos Estados Unidos, conforme relatado por THOMAS WYRIC e ROGER ARNOLD ${ }^{807}$. Os estados reduziram substancialmente a porcentagem de suas receitas vinculadas, passando do percentual de 51,3\% de suas receitas próprias em 1954 para 23\% em 1979. O estado da Geórgia costumava afetar sobremaneira suas receitas, chegando ao ponto de, em 1929, vincular 62\% para transporte e educação, em claro contraste com o contexto presenciado em 1993: as vinculações representavam, neste ano, apenas $6 \%$ das receitas totais daquele Estado ${ }^{808}$. JACOB WILNER SUNDELSON ${ }^{809}$ já àquela época advertia que os estados americanos, com as suas excessivas práticas vinculatórias, não poderiam lograr obter um orçamento equilibrado e bem-sucedido sem as competentes reformas orçamentárias.

\footnotetext{
${ }^{804}$ Cf. MERESSI, Fernando Sertã. Macrodinâmica..., p. 25. Grifos e destaques do original.

${ }^{805}$ Cf. Ely, Bruce P.; Walthall, Howard P. State..., p. 470.

${ }^{806}$ Cf. SouZA Franco, Antonio Luciano de. Manual..., p. 708.

${ }^{807}$ Earmarking..., p. 284.

${ }^{808}$ Cf. AlEXANDER, Frank S. Financing..., p. 369-71.

${ }^{809}$ Budgetary..., p. 263.
} 
Cumpre colocar em relevo que na França, em 1975, os recursos afetados representavam cerca de $40 \%$ do orçamento total, conforme demonstra JEAN CATHELINEAU $^{810}$, numeral este que, semelhantemente, verificava-se no Brasil à época. $\mathrm{O}$ autor, neste ínterim, já destacava para o perigo do esvaziamento do alcance do princípio da não afetação. Sob esta consideração, o que se verificou na França foi que, em 1983, as vinculações representavam $29 \%$ do total, representando uma sensível redução - segundo dados de ANDRÉ PAYSANT ${ }^{811}$.

Aqui, destaque-se que, desde 1950, a doutrina também já alertava para o perigo da vinculação excessiva de receitas $^{812}$. Naquela década, havia a vinculação de $30 \%$ das receitas do orçamento da União Federal; ainda assim, a política financeira optou por dar continuidade às práticas vinculatórias. Na Emenda Constitucional n ${ }^{\circ} 1$ de 1969 , no artigo $15, \S 3^{\circ}$, "f", também se vinculava $20 \%$ da receita tributária no ensino primário ${ }^{813}$. Depreende-se toda essa tendência histórica do gráfico abaixo:

\section{GRÁFICO I}

\section{Composição das Receitas Orçamentárias}

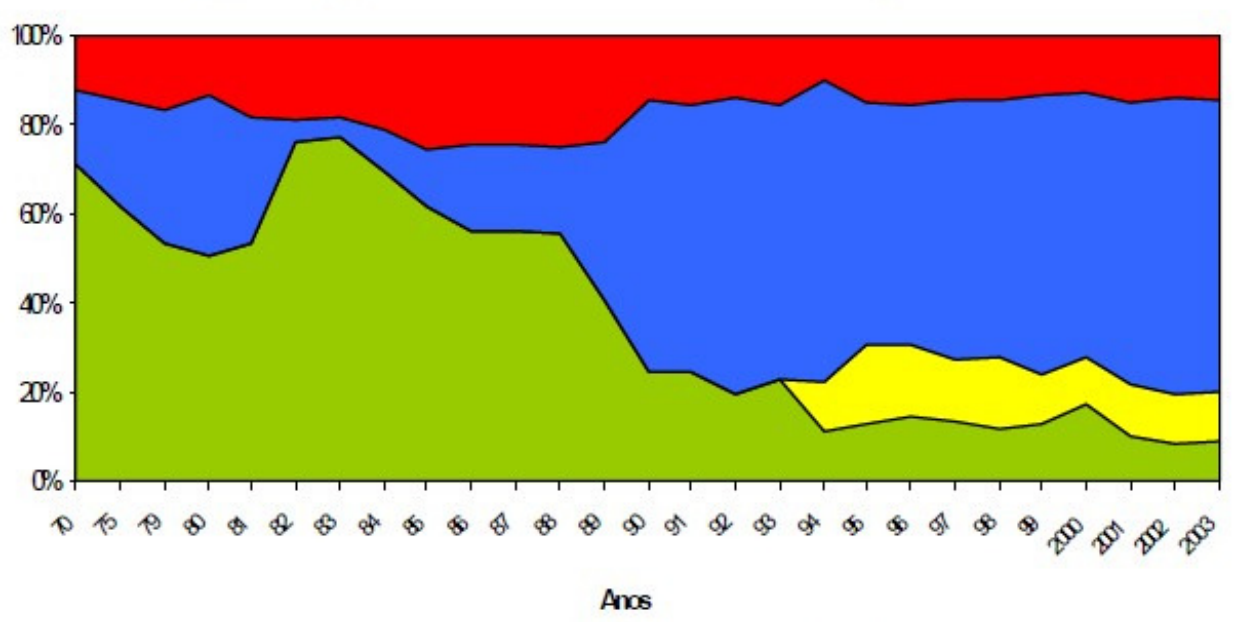

Obs 1 - Somente reccitas do Tesaur, descansideradas as de colocação de fit lios e de privafizaçães.

$\square$ Desvinculada $\quad$ FSEFEF/DRU $\square$ Vinculada $\square$ Tranf. Est/Mun.

Fonte: Secretaria de Orçamento Federal ${ }^{814}$.

\footnotetext{
810 Finances publiques: politique budgétaire et droit financier. Paris: Librairie générale de droit et de jurisprudence, 1975, p. 155.

${ }^{811}$ Finances..., p. 20.

${ }^{812}$ Cf. RochA, Ariosto de Rezende. Rendas..., p. 71.

${ }^{813}$ Cf. OliveIRA, Austen da Silva. Aspectos..., p. 82.

${ }^{814}$ Vinculações..., p. 6.
} 
De 1970 aos tempos atuais, houve uma queda de 50\% na liberdade do gestor público em utilizar os recursos segundo critérios de conveniência administrativa, diferentemente do que estava ocorrendo nos demais países ${ }^{815}$. DINO JARACH ${ }^{816}$ relembra que a afetação de recursos em excesso conduz as finanças públicas a uma rigidez nociva à economia de produção do serviço que possui a receita vinculada, além de solapar a racionalidade do sistema jurídico orçamentário, pois é da natureza da prática financista perquirir fins alternativos de obtenção de recursos para a fruição de determinado objetivo social.

Na terminologia técnica orçamentária, explica FERNANDO SERTã MERESSI ${ }^{817}$ que, com exceção da fonte 00 - Recursos Ordinários (que são de livre alocação pelo poder público), todo o restante das receitas públicas nacionais são oriundas de vinculações de receitas ("Fontes SOF"). Explica o economista:

Cada fonte de recurso nada mais é do que uma determinação legal para que certa(s) natureza(s) de receita destine(m) o total de sua arrecadação, ou parte dela, para determinados fins (despesas). Ou seja, a fonte de recursos é na verdade uma "ponte" entre as receitas e as despesas, prevista por mandamento legal. Exemplificando: no que diz respeito à fonte 12 (Recursos Destinados à Manutenção e ao Desenvolvimento do Ensino), a Constituição Federal, em seu art. 212, estabelece que ao menos $18 \%$ da receita de impostos deverão ser canalizadas para o Ensino.

Além disso, a situação pode ficar ainda mais preocupante quando se considera a política de priorizar o superávit primário, tal como a aplicada no Brasil, reduzindo ainda mais a parcela de despesas discricionárias ${ }^{818}$. Tal prática é descrita por HENRY LAUFENBURGER $^{819}$ como uma afetação de recursos à gestão da dívida pública, tendo sido utilizado em 1926 pelo governo francês mediante um dispositivo constitucional que criou um "caixa de amortização", cujo escopo era custear os empréstimos contraídos em virtude da intervenção estatal.

\footnotetext{
815 É oportuno recordar a ressalva de MARTA ARRETCHE (Quem taxa..., p. 82) quanto ao período compreendido em meados de 1970 a 1982, contexto este de progressiva desvinculação das receitas, principalmente dos entes subnacionais. Assim, em 1988, as transferências constitucionais passaram a ser na modalidade block grants, praticamente abolindo a "vinculação" das receitas transferidas, com exceção às despesas obrigatórias para educação e, posteriormente, da saúde. O FUNDEF, no entanto, veio posteriormente a ampliar este nível de vinculação das receitas dos entes subnacionais.

${ }^{816}$ Finanzas..., p. 83.

${ }^{817}$ Macrodinâmica..., p. 28-29.

${ }^{818}$ Tal tendência é verificada também na Lei de Responsabilidade Fiscal, introduzida neste contexto exposto. Na Mensagem de Veto $n^{\circ}$ 627, de 2000, o Presidente da República, ao vetar a alínea "a" do inciso III do artigo $5^{\circ}$, menciona que “(...) além das razões acima, o aludido dispositivo contraria outras disposições do presente projeto de lei complementar, que determinam a obtenção de superávits primário e nominal e dispõem sobre a compatibilização entre receita e despesa (...)" (destacou-se)

${ }^{819}$ Traité..., p. 57.
} 
Diante deste beneplácito dado pelo sistema orçamentário brasileiro ${ }^{820}$, graficamente é possível verificar a ampla e crescente utilização desta política de superávit primário a partir de 1998:

\section{GRÁFICO V}

EVOLUÇÃO DA RIGIDEZ ORÇAMENTÁRIA

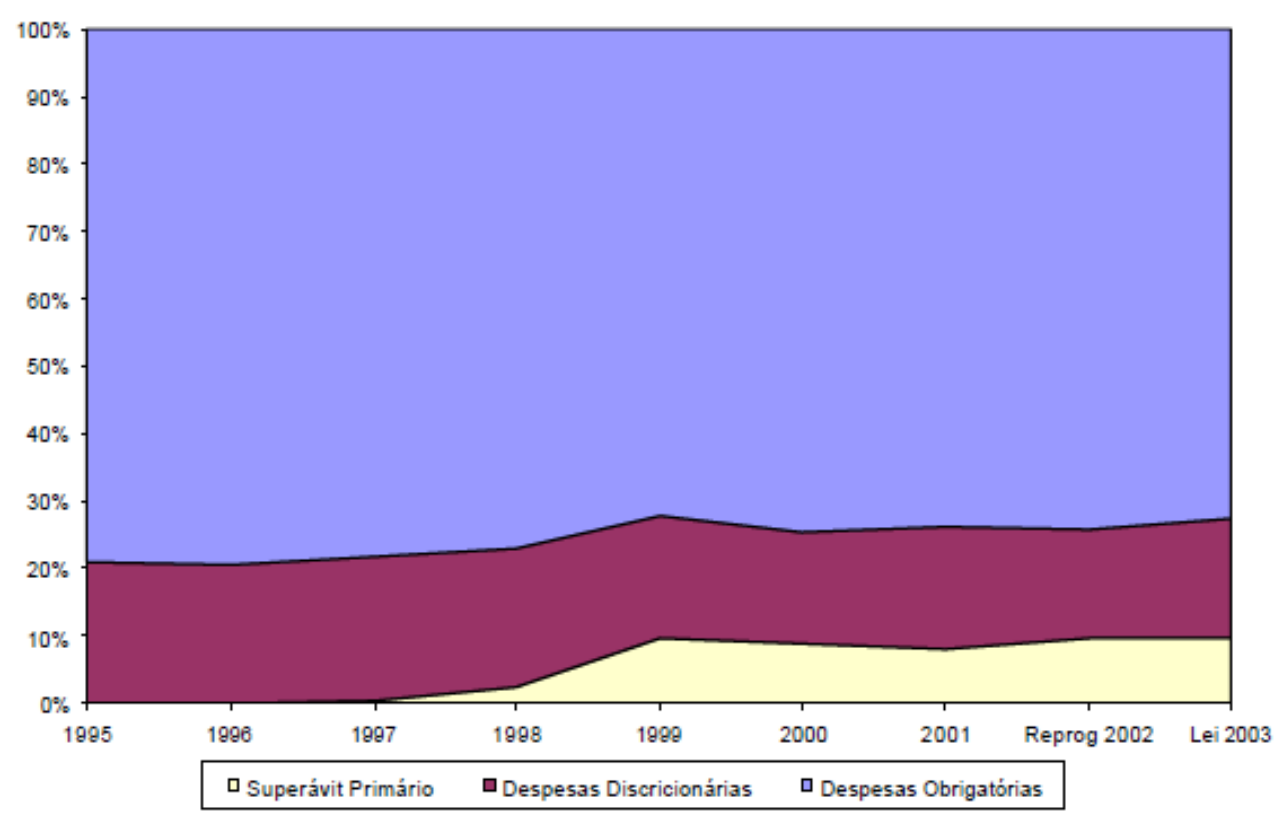

Fonte: Secretaria de Orçamento Federal ${ }^{821}$.

Perante todo este contexto de aumento das verbas estatais vinculadas, algum instrumento jurídico fatalmente teria que desafetar as receitas a fim de possibilitar a nova política fiscal concebida em 1998. Eis o surgimento da peculiar Desvinculação de Receitas da União - DRU.

\subsubsection{A DESVINCULAÇÃO DE RECEITAS DA UNIÃO - DRU}

Historicamente no Brasil, as sobras de verbas nunca puderam ser aplicadas em outros serviços - conforme explica o ex-senador LIBERATO DE CASTRO CARREIRA ${ }^{822}$. Em

\footnotetext{
${ }^{820}$ Cumpre apenas mencionar, quanto a este tema, que o Supremo Tribunal Federal, na ADI no $3.652 /$ RR (Pleno. Rel. Min. Sepúlveda Pertence. j. 19 dez. 2006. DJU 16 mar. 2007), entendeu que a divisão do superávit orçamentário aos Poderes e ao Ministério Público não se enquadraria na hipótese do artigo 167, IV, da Constituição Federal, porquanto seria uma mera distribuição interna destes recursos.

${ }^{821}$ Vinculações..., p. 12.

${ }^{822}$ Historia financeira e orçamentaria do imperio do Brazil desde a sua fundação, precedida de alguns apontamentos acerca da sua independência: Rio de Janeiro: Imprensa nacional, 1889, p. 69.
} 
1843 havia esta faculdade concedida ao gestor público, sendo cassada em 1856, restabelecida em 1867 e finalmente cassada novamente em 1877. Demonstra que esta imensa atividade pendular legislativa denotava uma indefinição acerca desta possibilidade, de forma que, sendo vedada no final do período imperial, é forçoso concluir que tal prática não foi muito bem acatada no seio da doutrina financista pátria.

BENVENUTO GRIZIOTTI ${ }^{823}$ reconhece que a hirteza de uma vinculação é a grande chagas orçamentária, podendo culminar em uma falsa estimativa de que será maléfica tanto se for para mais (levando ao desperdício) quanto para menos (levando à insuficiência). Desta forma, recomenda-se que a vinculação tenha elasticidade: a despeito de ela ligar recursos a finalidades específicas, deve possuir certa carga de maleabilidade ${ }^{824}$, tendo em vista que a natureza do montante do produto da arrecadação pública é a incerteza ${ }^{825}$.

Em Portugal, a doutrina entende que o princípio da não consignação de receitas veda a destinação de recursos a fins diferentes do previsto. Por outro lado, é aceita a tese de que, caso haja sobras de receita sobre a despesa, poder-se-ia utilizar este montante para custear outros serviços, conforme os ensinamentos de JosÉ JOAQUIM TEIXEIRA RIBEIRO, Antonio Luciano de Sousa Franco e Sabino Teixeira levantados no Acórdão $\mathrm{n}^{\circ}$ 452/87, do Tribunal Constitucional de Portugal, ocasião em que foi instado a se manifestar acerca da constitucionalidade da afetação de receitas de determinada taxa de registro, licenciamento e detenção de cães ${ }^{826}$.

Contudo, perante um contexto de falta de flexibilidade na alocação de receitas públicas afetadas, as crescentes vinculações constitucionais objetavam a reforma políticofiscal que o Brasil necessitava após longos períodos de inflação galopante e quase "falência" estatal. Desta forma, o governo do ex-Presidente Fernando Henrique Cardoso, em busca de uma política de ajuste fiscal, necessitava de maior elasticidade na condução das finanças públicas da União Federal.

$\mathrm{O}$ poder constituinte derivado era um instrumento adequado a pôr fim nestes entraves políticos para extinguir algumas vinculações, ou, então, reduzir o seu percentual no âmbito federal. A extinção de uma vinculação, conforme já ventilado ${ }^{827}$, é um ato

\footnotetext{
${ }^{823}$ Principios..., p. 375.

${ }^{824}$ Cf. RoCHA, Ariosto de Rezende. Rendas..., p. 45.

${ }^{825}$ Cf. LAufEnburger, Henry. Traité..., p. 55.

826 Disponível em:

$208 \&$ doc $=19880002 \% 20 \& v 02=\& v 01=2 \& v 03=1975-01-01 \& v 04=2008-07-$

$<$ http://dre.pt/cgi/dr1s.exe?t=d\&cap=1-

09\&v05=\&v06=\&v07=\&v08=\&v09=\&v10=\&v11=Ac\%F3rd\%E3o\&v12=\&v13=Tribunal\%20Constituciona $1 \& v 14=\& v 15=\&$ sort=0\&submit=Pesquisar \&d=2008-07-09\&maxDate=2008-07-09\&minDate=1960-01-01 > . Acesso em: 2 out. 2008.

${ }^{827}$ Ver itens 1.2 e 1.3 supra.
} 
dotado de tamanho peso político que se transformaria em um fardo a ser carregado pelo governo da época - o qual almejava celeridade e certo consenso entre os parlamentares para promover as reformas necessárias.

Porém, a manutenção de um número considerável de vinculações constitucionais também prejudicaria a realização de reformas pontuais, além do que retardaria o desiderato de uma política de ajuste fiscal. Algum instrumento inovador deveria ser utilizado, então, a fim de abarcar fatia das vinculações federais a ser destinada ao superátiv primário.

Desta forma, houve a revisão do conceito de afetação e a criação do instituto conhecido como Fundo Social de Emergência, introduzido pela Emenda Constitucional de Revisão $\mathrm{n}^{\circ}$ 1, de 1994, vinculando tributos para educação e saúde pelo artigo 71 do ADCT. Após, a Emenda Constitucional $\mathrm{n}^{\circ} 10^{828}$, de 1996, transformou-o em Fundo de Estabilização Fiscal ${ }^{829}$. Sua vigência foi, então, prorrogada pela Emenda Constitucional $n^{\circ}$ 17, de 1997, até 1999.

Ambos vinculavam recursos à saúde e educação sob a alegação de saneamento das contas públicas e estabilização da política econômica ${ }^{830}$. Eis os termos que remanesceram no artigo 71 do ADCT, após as sucessivas alterações:

Art. 71. É instituído, nos exercícios financeiros de 1994 e 1995, bem assim nos períodos de 01/01/1996 a 30/06/97 e 01/07/97 a 31/12/1999, o Fundo Social de Emergência, com o objetivo de saneamento financeiro da Fazenda Pública Federal e de estabilização econômica, cujos recursos serão aplicados prioritariamente no custeio das ações dos sistemas de saúde e educação, incluindo a complementação de recursos de que trata o $\S$ $3^{\circ}$ do art. 60 do Ato das Disposições Constitucionais Transitórias, benefícios previdenciários e auxílios assistenciais de prestação continuada, inclusive liquidação de passivo previdenciário, e despesas orçamentárias associadas a programas de relevante interesse econômico e social

A gênese da ideia de desafetação veio no inciso IV do artigo 72 do ADCT, ao estabelecer que $20 \%$ de toda a arrecadação de impostos e contribuições da União Federal ficaria destinada ao Fundo Social de Emergência. Posteriormente, a partir do ano 2000, surge a figura da Desvinculação das Receitas da União - DRU, prevista no artigo 76 do ADCT, introduzida pela Emenda Complementar 27, de $2000^{831}$. Após, as Emendas

\footnotetext{
${ }^{828}$ A constitucionalidade desta Emenda foi questionada no Supremo Tribunal Federal por meio da ADI 1.420-0/DF. Pleno. Rel. Min. Néri da Silveira. j. 17 mai. 1996. DJU 27 mai. 1996.

${ }^{829}$ Cf. GiaCOMONI, James. Orçamento..., p. 77.

${ }^{830}$ Cf. ToRres, Ricardo Lobo. Tratado..., p. 355. No Brasil, com a Desvinculação de Receitas da União, o autor entende que, à semelhança do Fundo de Estabilização Monetária, o objetivo é justamente "contingenciar dotações orçamentárias e gerar superávit primário para o pagamento da dívida pública, o que se conseguiu com sucesso nos últimos anos." Por fim, destacamos que, neste caso, ocorreu verdadeiramente uma vinculação, e não uma despesa mínima obrigatória, em razão da utilização de um Fundo para este fim.

${ }^{831}$ Cf. o histórico em TORRES, Ricardo Lobo. Tratado..., p. 340.
} 
Complementares $n^{\circ} 42 / 03$ e 56/07 prorrogaram o termo final - inicialmente previsto para 2003 - para 2011. Eis a ferramenta atual:

Art. 76. É desvinculado de órgão, fundo ou despesa, até 31 de dezembro de 2011, 20\% (vinte por cento) da arrecadação da União de impostos, contribuições sociais e de intervenção no domínio econômico, já instituídos ou que vierem a ser criados até a referida data, seus adicionais e respectivos acréscimos legais.

$\S 1^{\circ} \mathrm{O}$ disposto no caput deste artigo não reduzirá a base de cálculo das transferências a Estados, Distrito Federal e Municípios na forma dos arts. 153, § 5º 157 , I; 158, I e II; e 159, I, a e b; e II, da Constituição, bem como a base de cálculo das destinações a que se refere o art. 159, I, c, da Constituição.

$\S 2^{\circ}$ Excetua-se da desvinculação de que trata o caput deste artigo a arrecadação da contribuição social do salário-educação a que se refere o art. 212 , § 5o, da Constituição.

$\S 3^{\circ}$ Para efeito do cálculo dos recursos para manutenção e desenvolvimento do ensino de que trata o art. 212 da Constituição, o percentual referido no caput deste artigo será de $12,5 \%$ (doze inteiros e cinco décimos por cento) no exercício de 2009, $5 \%$ (cinco por cento) no exercício de 2010, e nulo no exercício de 2011. (destacou-se)

Conforme a própria dicção legal, não estão abrangidas as transferências para o federalismo fiscal, o financiamento do setor produtivo das Regiões Norte, Nordeste e Centro-Oeste ${ }^{832}$, e as verbas do Salário-Educação. Ou seja, a base de cálculo destas transferências, vinculações e despesas obrigatórias não sofrerá alterações pela incidência da DRU. Este dispositivo terá importância na análise do parágrafo terceiro, introduzido pela Emenda Complementar no 59 , de $2009^{833}$.

O que cumpre observar, por ora, é que o artigo desvincula - ou transforma em recursos livres, na terminologia orçamentária ${ }^{834}-20 \%$ da receita de impostos, contribuições sociais ou de CIDE, incidindo sobre a base de cálculo das afetações e despesas mínimas constitucionais obrigatórias, ressalvada as exceções já existentes.

É importante relatar que esta forma consiste, sobretudo, em uma mitigação das vinculações já existentes, de forma que se passe a desvincular aquelas receitas que já estavam afetadas constitucional ou legalmente. Conforme mencionado, o mais correto seria a abolição dos preceitos constitucionais que instituíram as referidas vinculações, porém, é provável que o quorum legislativo necessário para tanto dificultasse as revogações supressão esta que é, naturalmente, impopular. Não há governo que consiga erradicá-las

\footnotetext{
${ }^{832}$ Cf. BAlthAZAR, Ezequiel Antonio Ribeiro. Fundos constitucionais como instrumento de redução das desigualdades regionais na federação. In: ConTI, José Mauricio (org.). Federalismo fiscal. Barueri: Manole, 2004, p. 120-22. A regulamentação destes fundos surgiu com a Lei n ${ }^{\circ} 7.827 / 89$, sob a tutela do Ministério da Integração Nacional. Para tanto, servem como forma de fomentar o crescimento das regiões assinaladas, reduzindo as disparidades sociais e econômicas existentes no país.

${ }^{833}$ Ver item 4.2.2.1 infra.

${ }^{834}$ Cf. MERESSI, Fernando Sertã. Macrodinâmica..., p. 31.
} 
pacificamente, dado que qualquer tentativa neste sentido será encarada como uma forma de se diminuir os insuficientes recursos que já são destinados a áreas sociais relevantes, o que não cairá, por óbvio, nas graças dos eleitores e dos grupos de interesse. Desta forma, mitigam-se as vinculações sem correr o risco de que tal ato seja encarado como retrocesso político.

Diante disto, a Desvinculação de Receitas da União - DRU - transforma em recursos livres vinte por cento da arrecadação da União Federal com impostos e contribuições sociais e de intervenção no domínio econômico, influindo também, com o mesmo percentual, na base de cálculo das receitas afetadas e as despesas mínimas constitucionais - ressalvadas as exceções constitucionais -, podendo ser utilizados para formação de superávit primário.

\subsubsection{A POSTERIOR MITIGAÇÃO DA DESVINCULAÇÃO DE RECEITAS DA UNIÃO}

Em 2009, houve a inclusão do parágrafo terceiro no artigo 76 do ADCT por meio da Emenda Constitucional $n^{\circ} 59$, oriunda da Proposta do Senado Federal de Emenda à Constituição no 96 e 96A, de 2003 - a qual mitigou a aplicação da desvinculação das receitas para os recursos destinados à educação, reduzindo o seu percentual de incidência. Desta forma, passou-se a assegurar quantia maior de recursos para esta seara.

Com base em dados do Ministério da Educação, a autora da PEC (Senadora Ideli Salvatti - PT) explica em sua justificativa que mais de três bilhões de reais de verbas anuais não são aplicadas nas ações destinadas à manutenção e desenvolvimento do ensino, já que a DRU incidiria como um redutor na base de cálculo do mínimo percentual para esta seara. Com isto, originou-se a proposta para que houvesse uma sensível e gradual diminuição nesta incidência, até atingir ao patamar zero em $2011^{835}$.

O fato é que a proposição considera que a DRU incide substancialmente sobre as verbas destinadas à educação (que seriam "vinculações"), conforme se depreende do Parecer da Comissão de Constituição, Justiça e Cidadania, do Relator Senador Jefferson Péres:

${ }^{835}$ Disponível em: <http://www.senado.gov.br/sf/atividade/Materia/getPDF.asp?t=38576>. Acesso em: 19 abr. 2010. 
Com o mecanismo da Desvinculação de Receitas da União (DRU), 20\% dos recursos destinados pela Constituição para o financiamento da educação podem ser livremente alocados. Esses recursos são destinados a outras despesas e ao superávit primário, com evidente prejuízo para o sistema educacional do País, ficando a maior parte dos encargos da educação sob a responsabilidade dos estados e municípios

(...)

Nesse contexto, a PEC n ${ }^{\circ}$ 96, de 2003, propõe corrigir essa distorção. Ela estabelece a redução gradativa da DRU, para efeito do cálculo dos recursos para manutenção e desenvolvimento do ensino (MDE) de que trata o art. 212 da Constituição Federal. Assim, os recursos vinculados à educação seriam gradativamente recuperados, permitindo o aumento e a melhoria da educação pública ${ }^{836}$.

Posteriormente, esta linha de raciocínio foi corroborada no Parecer $n^{\circ} 1.756$, de 2009, da Comissão de Constituição, Justiça e Cidadania, da Relatora Senadora Lúcia Vânia, exarado na Proposta do Senado Federal de Emenda à Constituição nº 96A, que originaria a norma jurídica em comento ${ }^{837}$.

A redação do dispositivo introduzido é confusa, pois remete ao cálculo dos mínimos obrigatórios vinculados à educação, contidos no artigo 212 da Constituição, porém, não menciona que a aplicação da DRU está mitigada no caso da educação com percentuais diferenciados de incidência na base de cálculo - o que seria mais acertado em razão de se tratar de uma norma de exceção à regra geral.

Mais correto seria adotar, v. g., a forma de redação utilizada no artigo 72 do ADCT, quando da instituição do Fundo Social de Emergência, ao prever no parágrafo terceiro o seguinte dispositivo:

Art. 72. Integram o Fundo Social de Emergência:

(...)

IV - vinte por cento do produto da arrecadação de todos os impostos e contribuições da União, já instituídos ou a serem criados, excetuado o previsto nos incisos I, II e III, observado o disposto nos $\S \S 3^{\circ}$ e $4^{\circ}$;

(...)

$\S 3^{\circ}$ A parcela de que trata o inciso IV será previamente deduzida da base de cálculo das vinculações ou participações constitucionais previstas nos artigos $153, \S 5^{\circ}, 157$, II, 212 e 239 da Constituição.

(...)

$\S 4^{\circ} \mathrm{O}$ disposto no parágrafo anterior não se aplica aos recursos previstos nos Artigos 158 , II e 159 da Constituição. (destacou-se)

\footnotetext{
836 Disponível em: <http://www.senado.gov.br/sf/atividade/Materia/getPDF.asp?t=22915>. Acesso em: 22 dez. 2009.

${ }^{837}$ Disponível em: <http://www.senado.gov.br/sf/atividade/Materia/getPDF.asp?t=67452>. Acesso em: 22 dez. 2009. "A par disso, embora a extinção da DRU em relação à educação não implique necessariamente o aporte imediato de recursos vultosos à área, ela tem o importante papel de assegurar que o mínimo constitucional seja restabelecido. Com isso, abre-se a perspectiva de que novos recursos possam sejam paulatinamente reivindicados e conquistados para o enfrentamento dos desafios de desenvolvimento social do País, que não acontecerá enquanto a educação básica ficar relegada a plano secundário, como privilégio de uns poucos."
} 
Quando o dispositivo legal retira a aplicação do inciso IV na base de cálculo das vinculações e participações, significa que estes $20 \%$ devem ser descontados no cálculo do montante a ser "vinculado" nos dispositivos mencionados, ou seja, as repartições do federalismo fiscal dos arts. 153, § $5^{\circ}$ (transferências do IOF-ouro), 157, II (20\% dos impostos residuais da União) e as despesas mínimas na educação (art. 212) e PIS (art. 239).

Até a introdução do parágrafo terceiro, a DRU era passível de aplicação integral sobre a base de cálculo do mínimo para educação. Assim, a interpretação a ser feita com o seu advento é que a desvinculação incide sobre a base de cálculo as despesas de manutenção e desenvolvimento do ensino até os limites percentuais estabelecidos para 2009 e 2010. Já em 2011, quando este percentual será nulo, o Governo Federal não poderá fazer incidi-la na base de cálculo dos mínimos obrigatórios para educação.

\subsubsection{ASPECTOS CONSTITUCIONAIS DA DESVINCULAÇÃO DE RECEITAS DA UNIÃO}

Apartada da discussão constitucional da DRU, adicionaríamos inicialmente que alguns autores a veem, tecnicamente, como prática orçamentária vã. Isto ocorre porque caso seja desvinculada parcela de recursos do Orçamento da Seguridade Social, determinada fatia do Orçamento Fiscal deverá custear o déficit oriundo desta desvinculação, já que as despesas, naquele primeiro Orçamento, tornaram-se, em sua maioria, obrigatórias ${ }^{838}$. Diante disto, estes gastos, transformados em obrigatórios pela sua própria natureza, deverão ser custeados de qualquer forma - seja ou não por recursos vinculados. Sob o aspecto técnico-orçamentário da DRU, inclinamo-nos a concordar com essa opinião, pois as despesas com a Seguridade Social continuarão presentes, vinculadas ou não, devendo haver a sua plena satisfação.

Com relação à constitucionalidade da DRU, a doutrina vem se debatendo sobre a possibilidade de haver a desvinculação dessas verbas sem que haja a contaminação pela inconstitucionalidade. São levantados diversos aspectos com relação a esse ponto. A opinião de RICARDO LOBO TORRES ${ }^{839}$, contrária às afetações, é que a inconstitucionalidade estaria na vinculação ao invés da desvinculação.

\footnotetext{
${ }^{838}$ Cf. MERESSI, Fernando Sertã. Macrodinâmica..., p. 31.

${ }^{839}$ Tratado..., p. 355, nt. 699.
} 
Primeiramente, com relação à legalidade, levanta-se a hipótese de que se parcela do tributo afetado não está sendo aplicada à sua afetação, poderia haver a repetição do indébito pago. Esta tese tributária da efetividade ou não da afetação com relação ao sujeito passivo da obrigação tributária é suscitada na Espanha por RAFAEL CALVO ORTEGA ${ }^{840}$, podendo, naquele país, acarretar - ou não - a devolução do montante arrecadado dependendo da essencialidade ou acessoriedade da vinculação.

No Brasil, KIYOSHI HARADA ${ }^{841}$ entende que a efetividade da afetação não pode ser alegada pelos contribuintes no momento da exação tributária, sobretudo porque a relação jurídico-tributária extinguir-se-ia com o pagamento do imposto, não havendo relevância para a obrigação tributária a destinação dos recursos dentro do orçamento.

Em nossa opinião, assiste razão ao jurista. O Código Tributário Nacional, sabiamente, em seu artigo $4^{\circ}$, II, define a irrelevância da destinação do produto da arrecadação para fins da natureza jurídica do tributo. Há também entendimento no sentido de que este artigo seria aplicável somente aos impostos - em razão do advento do artigo 167, IV, da Constituição de 1988, que teria restringido o âmbito de aplicação daquele dispositivo do codex tributário $^{842}$. KIYOSHI HARADA ${ }^{843}$ conclui que:

Ao contribuinte, não cabe indagar o que será feito com o produto da arrecadação de impostos, pelo menos enquanto contribuinte. Porém, enquanto cidadão, poderá questionar não só a vinculação, como também a má aplicação dos recursos advindos de tributos em geral.

Logo, conforme exposto, não é possível haver a repetição do indébito com fulcro na destinação dada à receita do tributo, uma vez que a tese do ressarcimento ao contribuinte em razão da não aplicação da arrecadação às finalidades previamente estabelecidas não encontra abrigo no ordenamento pátrio.

A doutrina, em defesa à constitucionalidade da DRU mediante uma interpretação conforme a Constituição Federal, entende que ela não esbarra no obstáculo da inconstitucionalidade em homenagem ao princípio da eficiência da Administração Pública $^{844}$. Adicionamos, neste ensejo, a necessidade de uma reapreciação da já mencionada disposição contida no parágrafo único do artigo $8^{\circ}$ da Lei de Responsabilidade

\footnotetext{
${ }^{840}$ Curso..., p. 81.

${ }^{841}$ Direito financeiro e tributário. 10. ed. São Paulo: Atlas, 2002, p. 85-86.

${ }^{842}$ Cf. SCAFF, Fernando Facury. Para além..., p. 1143-44.

${ }^{843}$ Direito..., p. 86.

${ }^{844}$ Cf. IBRAHIM, Fábio Zambitte. Desvinculação parcial da arrecadação de imposto e contribuições: uma interpretação possível da Emenda Constitucional no 27. Revista Dialética de Direito Tributário. São Paulo. n.61. 2000, p. 48.
} 
Fiscal $^{845}$. Com o permissivo constitucional trazido pelo artigo 76 do ADCT, não se pode estender a abrangência deste dispositivo à DRU, pela própria hierarquia superior da norma constitucional. A sobredita regra da Lei de Responsabilidade Fiscal é válida, evidentemente, apenas para os recursos vinculados; já aos recursos desvinculados pelo instrumento constitucional da DRU, não há que se falar em contradição com a LRF.

Ademais, cumpre salientar a nossa opinião de que a DRU não altera a natureza jurídica do tributo afetado. Consoante sobredito, a desvinculação é sobre $20 \%$ da receita total de impostos, contribuições sociais e CIDEs, incidindo também sobre a base de cálculo das vinculações e despesas obrigatórias que não são excepcionadas: não significa que $20 \%$ de determinado tributo seja desvinculado. A desafetação é da arrecadação da União, e não de tributo específico. Pode ser que, em virtude de técnica contábil, a DRU seja aplicada individualmente sobre cada tributo arrecadado, desvinculando $20 \%$ de sua receita arrecadada vinculada. Porém, o artigo 76 do ADCT não faz esta diferenciação, já que utiliza a expressão arrecadação da União - o que pressupõe que seja o total das receitas dos tributos mencionados no dispositivo, e não de cada um dos tributos especificados.

Para elucidar esta posição, pode-se mencionar um exemplo hipotético de existência da desvinculação de 100\%, 50\%, 20\%, 15\%, 1\%, ou, até mesmo, a não desvinculação das receitas da CIDE-Combustíveis em um determinado exercício financeiro. O quantum que foi desvinculado de cada tributo somente será aferível mediante procedimentos contábeis na análise do orçamento. A DRU, por incidir na arrecadação da União nos tributos que menciona, permite que o tributo seja desvinculado em qualquer cifra, desde que dentro do limite dos $20 \%$ do total da arrecadação da União Federal com contribuições sociais, impostos e CIDE.

Além destes aspectos, faz-se mister trazer à baila que outra parte da doutrina entende que a DRU é contaminada pela inconstitucionalidade ao prever a desafetação das receitas das contribuições sociais ${ }^{846}$, pois se trataria de tredestinação dos recursos arrecadados que são insitamente coligados a uma finalidade constitucional prestacional justificadora de sua criação. O grande impasse doutrinário é, portanto, com relação à desvinculação das receitas destinadas aos gastos sociais. Desta forma, a DRU seria

\footnotetext{
${ }^{845}$ Ver item 2.2.2 supra.

${ }^{846}$ Cf. BREYNER, Frederico Menezes. Inconstitucionalidade da Desvinculação das Receitas da União (DRU) quanto às Contribuições Sociais sob a Ótica dos Direitos Prestacionais Fundamentais. Disponível em: $<$ http://www.sachacalmon.com.br/admin/arq_publica/58d2d622ed4026cae2e56dffc5818a11.pdf $>$. Acesso em: 20 out. 2008. Número de página desconhecida em razão da ausência de numeração no documento.
} 
inconstitucional por desviar recursos que originalmente deveriam ser dotados para garantir estes direitos prestacionais ${ }^{847}$, e, por esta razão, esbarraria na cláusula inabolível do artigo $60, \S 4^{\circ}$, IV da Constituição da República.

Caso sejam consideradas, como premissa, as vinculações como uma das facetas de proteção aos direitos prestacionais - instituídos pelo constituinte originário - para vedar abusos por parte do Legislativo (poder derivado) e Executivo, qualquer tentativa de supressão constituirá burla à cláusula pétrea. A proteção aos direitos garantidos pela cláusula pétrea seria impassível de restrição tanto na faceta do custeio (vinculação) como na efetivação do direito em si, conforme o mandamento constitucional.

Porém, caso se conceba a vinculação apenas como um instrumento financeiro para estabelecer um elo entre fonte e destino, nesse caso ela não seria uma ferramenta a serviço exclusivo dos direitos prestacionais - o que salvaguardaria a constitucionalidade do dispositivo. Seria uma das inúmeras técnicas a fim de se destinar recursos a uma atividade prestacional. A nossa propensão é pela aceitação deste tipo de interpretação diante da concepção de vinculação abordada neste trabalho.

Corroborando esta concepção, pode-se exemplificar, de forma fictícia, a instituição de uma norma financeira pela Constituinte de 1988 que dispusesse que o pagamento das despesas com educação deverá ocorrer sem o empenho e liquidação regime estabelecido nos artigos 58 a 70 da Lei $n^{\circ} 4.320 / 64$ - a fim de dinamizar a ordenação de despesas para este setor. Esta norma não se constituirá em cláusula pétrea, pois, como técnica financeira, apenas intenta perseguir o melhor asseguramento do direito fundamental à educação. Mas é possível que a técnica utilizada não seja a mais adequada, ou, então, torne-se inadequada com o passar do tempo. Neste caso, poderá ser suprimida e introduzida, ou não, outra norma, de acordo com a necessidade da nação - como uma vinculação de receitas, despesa obrigatória, limitação de contingenciamento, dentre outras.

Ademais, uma vinculação que supostamente possa ser utilizada para garantir recursos à defesa de um direito fundamental pode prejudicar outro. Imagine-se uma vinculação de $50 \%$ de todas as receitas federais para erradicação do analfabetismo: consequentemente, outros setores, também imprescindíveis, terão menos recursos para suas finalidades, como e. g., desporto, ciência e tecnologia, segurança pública ou assistência social. Outra situação hipotética é a existência de quarenta vinculações constitucionais, cada uma de $1 \%$ da receita total, para distribuição de recursos em setores sociais: como

${ }^{847}$ Cf. SCAFF, Fernando Facury. Direitos humanos..., p. 48-49. 
ficará, neste caso, o custeio da infraestrutura ou das despesas dos Parlamentares, por exemplo?

Desta forma, seria inglória - senão impossível - a tarefa de identificação, pelo intérprete jurídico, da quantidade e grau destas vinculações que estariam garantindo, de fato, os direitos fundamentais prestacionais sem subjugar as demais obrigações constitucionais. $\mathrm{Ou}$, em outras palavras, definir qual seria o limite exato em que a vinculação deixa de garantir um direito e passa a violar os demais. Pode ser que vincular $50 \%$ das receitas para programas voltados à alfabetização seja excessivo - ou não. Dependerá, verdadeiramente, do que se estabelece como prioridade social na governança no País.

Outro ponto que pode ser levantado é que a DRU, em função de sua própria natureza, não determina constitucionalmente para qual despesa os $20 \%$ desvinculados devem ser direcionados. Pode ser que a quantia desvinculada seja aplicada nos próprios direitos prestacionais ditos violados, ou até mesmo em outros de igual relevância. Assim, é possível que $20 \%$ das contribuições sociais desvinculadas sejam direcionadas exclusivamente para a erradicação da fome no Brasil, e, nesse caso, seria áspero afirmar que se está havendo violação dos direitos sociais mais fundamentais para uma nação.

Em síntese, a vinculação, mero instrumento no processo de alocação das receitas públicas, não é bastante em si para assegurar estes desideratos mais essenciais do País. O que realmente resguardará a observância dos direitos prestacionais pelo Estado são políticas públicas voltadas a gastos eficientes, com prioridades e metas preestabelecidas, além da gestão responsável da coisa pública pelos seus governantes. 


\section{SÍNTESE CONCLUSIVA}

As vinculações, afetações, consignações ou gravações de receitas designam as receitas carimbadas que derrogam certos corolários de direito financeiro, visto que fazem com que determinado custeio tenha a sua fonte de receita imediatamente identificada por meio de uma ligação jurídica. Economicamente, esta correspondência pode ocorrer entre tributo e uso (amplo ou específico) e receita e uso (também amplo ou específico).

No âmbito jurídico, as vinculações de receitas são positivadas por instrumentos constitucionais ou legislativos de forma alheia à lei orçamentária, e são utilizadas para individualizar uma fonte e destinação mediante o estabelecimento de um elo jurídico entre receitas e escopos predeterminados, possuindo margem relativa de abolição do ordenamento e constituindo uma excepcionalidade à dinâmica orçamentária.

Politicamente, as vinculações são vistas como instrumentos institucionais que engessam o dinamismo da atividade orçamentária, influenciando nas tomadas de decisões posteriores em um processo de path dependence, já que elas "pré-comprometem" as ações políticas dos futuros governantes. Esta seria a exteriorização dos efeitos simbólicos e institucionais das vinculações. No Brasil, ocorre um exemplo desta vinculação simbólicoinstitucional com as universidades paulistas, porquanto em todo ano na lei de diretrizes orçamentárias segue-se a praxe de se destinar percentual fixo a estas instituições por meio da especialização orçamentária.

Além deste fator, a vinculação de receitas pode servir como dotadora de autonomia financeira de um dos Poderes. Cite-se, por exemplo, as constantes consignações constitucionais ao Poder Judiciário de diversas nações. Em suma, as afetações de receitas, como processo político, por meio de instrumentos simbólicos e institucionais précomprometem as gerações políticas posteriores, além de condicionar o rumo da aplicação dos recursos públicos nas decisões subsequentes e garantir a autonomia financeira a certos entes - como os Poderes da nação.

A vinculação possui também alguns critérios temporais para a sua verificação, bem como a questão de observância do órgão envolvido em uma afetação, o que pode gerar discussão em torno do fenômeno tributário da parafiscalidade. Com relação a este critério, a afetação é vista como dotadora de autonomia a um serviço público e ao órgão responsável, o que daria alguns efeitos benéficos visto pela doutrina jurídica e econômica, 
mormente em questões de eficiência e de efeito psicológico positivo aos contribuintes com relação à aplicação dos recursos públicos.

No que toca ao momento da arrecadação de receita, há a questão de saber o seu grau de importância para se determinar a vinculação, isto é, se ela se queda afetada antes ou depois da arrecadação. Ocorre que, em sede de direito financeiro, a entrada é o ingresso de recursos nos cofres públicos; quando definitiva, torna-se receita. Assim, segundo esta classificação, a receita arrecadável não estaria no conceito de vinculação de receitas. Porém, entendemos por um conceito teleológico de receitas nesse caso, abarcando também os recursos não arrecadados (futuras receitas), pois caso contrário não haveria sentido lógico na própria afetação.

Igualmente, a vinculação de receitas não se confunde com a técnica parafiscal, visto que a parafiscalidade é a possibilidade de destinação de recursos a um sujeito ativo para a consecução de suas atividades específicas com certa autonomia, não sendo considerados dentro da disponibilidade orçamentária do ente federativo por se tratar de um fenômeno paraorçamentário.

Outro problema que advém dos critérios temporais é com relação ao redirecionamento de receita, isto é, a vinculação de verbas a entidade diversa da responsável pela sua arrecadação - como pode ocorrer no caso de autarquias. No caso, o empecilho dar-se-ia não pela regra constitucional da impossibilidade de afetação de receitas, mas sim pela autonomia financeira de alguns entes da Administração Pública.

É possível classificar as afetações quanto ao seu efeito e função. Para tanto, as vinculações podem ser fortes ou fracas (de acordo com a determinação do gasto público) e amplas ou estreitas (conforme sua abrangência). Aparecem, contudo, em formas combinadas (forte e ampla, forte e estreita, fraca e ampla, fraca e estreita).

Quanto às funções, as vinculações podem ser stricto sensu - quando há a evidente relação da fonte com o custeio. Pode haver também "vinculações" para o federalismo fiscal, embora se trate de concepção mais ampla e imprópria do instituto. Outra função comum é a vinculação-garantia, utilizada em contratos e empréstimos públicos. A doutrina ainda considera a possibilidade de vinculação como punição ou repressão a certas condutas que determinada agenda política deseja evitar; não é, contudo, tecnicamente uma função da vinculação, mas sim o aparecimento do fenômeno da extrafiscalidade. Por fìm, há a vinculação compensatória em contraponto a perdas financeiras de um determinado ente.

As vinculações costumam ser alvos de críticas e elogios pela doutrina, não havendo consenso no que concerne à sua aplicação, o que dependerá do ponto de partida 
tomado para o seu estudo doutrinário. Assim, exsurge o trade-off entre flexibilidade e controle orçamentário. As principais críticas relacionam-se com o seu desperdício de recursos, automatismo e engessamento das contas públicas, dificultando a sua maleabilidade. Já os benefícios apontados são considerados em razão da maior facilidade de controle na aplicação dos recursos, bem como a maior aceitação popular de um tributo vinculado, servindo como indutor das preferências populares. Também garante um fluxo de receitas contínuo para áreas que sejam consideradas mais importantes. Há, ainda, algumas práticas que se configuram em falsas vinculações, visto que, sem o comando normativo que instrumentalize essa vinculação, os recursos podem ser aplicados em fins diversos ao da vinculação.

Com relação às vinculações de receitas no Brasil, surgiram como forma de preservar alguns desideratos importantes para as nações. Atualmente, há diversas vinculações constitucionais para fins específicos, além das permissões contidas a contrario sensu no artigo 167, IV, da Constituição Federal. Aparecem, nestes casos, na forma de vinculações stricto sensu: estas afetações podem ser definidas como a exata correlação entre despesa e receita, de acordo com a definição jurídica de vinculação, ou seja, são aquelas vinculações propriamente ditas, externadas mediante o estabelecimento de um elo entre uma fonte de receita para um escopo específico.

Prática recorrente e que facilita a visualização destas vinculações são as consignações de receitas da tributação sobre combustíveis, destinadas geralmente para as rodovias nacionais (operacionalizadas normalmente por um fundo). É uma modalidade quid pro quo de vinculação, pois o combustível costuma ser relacionado com o uso das rodovias, aparecendo como item complementar. Desta maneira, o princípio do benefício fica mais perceptível ao usuário pelo seu consumo e contribuição na formação destes recursos e investimentos vinculados.

Esta prática foi razoavelmente fomentada no século passado nos Estados Unidos, sendo alvo, todavia, de algumas críticas, principalmente no tocante à boa gestão fiscal destes recursos. No Brasil, ocorreu o mesmo problema com o Fundo Rodoviário Nacional, vinculando os recursos do Imposto Único Federal sobre Combustíveis e Lubrificantes Líquidos Minerais. Porém, em 1988, o artigo 167, IV, ao vedar a vinculação de receitas de impostos, extinguiu esta prática, substituindo-a pela instituição da CIDE-Combustíveis.

Com relação às vinculações constitucionais, deve-se observar a necessidade de vedação às vinculações indiretas de receita de impostos. Ocorre tal modalidade em casos de concessões de benefícios à população - pela Administração Pública - com a respectiva 
compensação, ao prestador de um determinado serviço, mediante o aumento de alíquota ou renúncia parcial da receita de certo tributo, vinculando este acréscimo ou redução obliquamente ao custeio do benefício em questão. O Supremo Tribunal Federal costuma rechaçar este tipo de vinculação, muito comum, sobretudo, em casos envolvendo o ICMS.

Outrossim, merece ser comentada a impossibilidade de vinculação temporária de receitas que não seja sob os ditames do artigo 167, IV, da Constituição Federal. E, também, no caso de serviços extraordinários e temporários, este tipo de prática não seria a melhor técnica orçamentária, já que há a possibilidade de se utilizar a competência tributária excepcional concedida pela própria Constituição.

No caso do federalismo fiscal, é possível constatar um uso impróprio do termo vinculação, não se constituindo no conceito clássico já exposto. Diante disto, a doutrina costuma tentar identificar nas estruturas de federalismo fiscal determinadas características que se assemelham às vinculações de receita. Assim, as repartições operacionalizadas pelos Fundos de Participação dos Estados e Municípios costumam ser vistas com este fim, dado que o próprio constituinte de 1988 inseriu-as na disciplina das vinculações de receita.

As despesas obrigatórias são, substancialmente, obrigações a todos os entes federativos de gastos mínimos em determinada seara social. Não se confundem com as vinculações: aquelas obrigam ao gasto em determinado exercício financeiro, diferentemente das afetações. Estas últimas podem ter os recursos utilizados em exercício diverso do arrecadado, consoante disposição do artigo $8^{\circ}$, parágrafo único, da LRF, desde que respeitado o vínculo estabelecido entre receita e despesa. Exemplos típicos de despesas obrigatórias estão na saúde e educação, com as respectivas Emendas Complementares $\mathrm{n}^{\circ}$ 29, de 2000, e no 14 , de 1996 e n ${ }^{\circ} 53$, de 2006.

A vinculação de receitas também pode ser utilizada na sua modalidade de garantia. É uma garantia orçamentária ao beneficiário, e não real ou pignoratícia como a usada no direito civil. É usada pelos entes federativos de forma a atenuar a desconfiança existente no que toca ao adimplemento dos débitos estatais. Em resumo, a vinculação de receitas, na função de garantia (vinculação-garantia), traduz-se no comprometimento orçamentário de que os recursos deverão ser utilizados para o adimplemento da obrigação contraída, sendo vedadas a dupla vinculação e autossatisfação do débito por meio das receitas garantidas.

No Brasil, o uso das vinculações como garantia, apesar de vetusto, veio a ser disciplinado pela Lei de Responsabilidade Fiscal no tocante às garantias intergovernamentais. Em 2004, a Lei das Parcerias Público-Privadas (nº 11.079/04) 
instituiu a vinculação-garantia nas relações entre poder público e iniciativa privada em seu artigo $8^{\circ}$, I. No entanto, tal inserção mostra-se prescindível: qualquer vinculação de imposto já é vedada constitucionalmente e, a contrario sensu, outras afetações que não a de impostos já são permitidas pelo ordenamento. A doutrina costuma criticar tal dispositivo por entendê-lo como burla ao princípio da não afetação da receita de impostos, assim como ao regime de precatórios.

Porém, a interpretação do instituto deve se dar de forma compatível aos demais dispositivos constitucionais e legais. Por exemplo, pode haver a vinculação de receita de preço público ou royalties de recursos naturais como garantia ao parceiro privado. E também não há descumprimento ao regime de precatórios por não haver crédito controvertido em face da Fazenda Pública reconhecido judicialmente. É mera hipótese de adimplemento contratual.

Com relação aos fundos obrigatórios de repartição de receitas no federalismo, não pode a União ou Estados, por exemplo, deixar de entregar ou utilizar estes recursos como forma de pagamento pela inadimplência, pois são de titularidade do ente beneficiado ainda que não transferido. Logo, a retenção dos créditos nas garantias interfederativas para autossatisfação, conforme já anunciado pela doutrina, é inconstitucional. O artigo 40, § $1^{\circ}$, II, da LRF é inconcebível no nosso ordenamento, pois a União não pode utilizá-los para saldar a dívida pendente.

Outro exemplo ocorreu com a Lei Baiana $n^{\circ} 11.477 / 2009$ que, ao vincular a quota-parte que lhe cabe no Fundo de Participação dos Estados para as Parcerias PúblicoPrivadas, ficou maculada pela pecha da inconstitucionalidade. Tal "vinculação" só poderia se dar no âmbito das relações de federalismo fiscal, ou seja, somente seria possível se a "vinculação" fosse para transferência intergovernamental das receitas já transferidas aos municípios situados em seu território.

Relacionados intimamente com a questão das vinculações estão os princípios ou regras de direito financeiro, principalmente da unidade, universalidade e não afetação de receitas. A doutrina anglo-saxã, diferentemente da romano-germânica, costuma minimizar a sua importância na gestão orçamentária. Contudo, o princípio da não vinculação positivado ou não - ocupa lugar preponderante na regência da dinâmica das vinculações no ordenamento.

Isto ocorre porque a não afetação de receitas públicas proclama a vedação do estabelecimento de vínculo - entre uma fonte a determinado destino - a fim de que o total das receitas faça frente às despesas de forma genérica. 
No Brasil, é inscrito constitucionalmente no artigo 167, inciso IV, da Constituição Federal, circunscrevendo esta proibição somente à espécie tributária “imposto". Paralelamente, é relevante considerar que o dispositivo considera vulgarmente as repartições para o federalismo fiscal e as despesas obrigatórias como vinculações, e vislumbra as afetações com função de garantia no ordenamento brasileiro, excepcionando da regra geral estas hipóteses expressamente consignadas.

Sua razão de existência está calcada na concepção neutra que a doutrina prega nas finanças públicas, sem que haja constantes hierarquizações de gastos em detrimento da massa única de recursos. E também garante que os contribuintes, ao recolherem o tributo, tenham o dever fundamental de fazê-lo mesmo sem uma contraprestação direta como compensação pela contribuição. Assim, prioriza-se o caráter solidário que envolve a atividade de arrecadação. O princípio da não afetação costuma ser visto juntamente com a unidade e universalidade, estes dois últimos subdividindo-se, respectivamente, nos princípios do orçamento bruto e unidade de caixa.

Em sua concepção atual, entendemos que o princípio da unidade congrega todas as receitas e despesas sob um liame lógico-orçamentário, mantendo uma unidade de desígnios na atividade orçamentária estatal. Muitos doutrinadores o consideram como ligado ao princípio da não afetação por sua faceta contábil, considerando que ele evita o surgimento dos orçamentos marginais e anexos, contas especiais ou orçamentos extraordinários (formas comuns de operacionalização da vinculação de receitas). Daí deriva outra regra importante, que é a unidade de caixa. Porém, esta última é consequência lógica do princípio da unidade, podendo abarcá-la em prol da concepção tripartite adotada no ordenamento brasileiro (princípio da unidade, universalidade e não afetação).

De outra banda, o princípio da universalidade comporta a inscrição de todas as receitas e despesas orçamentárias pelo seu valor bruto, de forma a possibilitar a ciência detalhada e controle das contas públicas de forma global. Diferentemente da unidade, correlata mais às regras contábeis, a universalidade é vista como a faceta política do orçamento. Serve para evitar os caixas negros, ou a falta de transparência nas gestões espúrias, obrigando que a completa discriminação das receitas e despesas traduza-se na verdade orçamentária por detrás das contas públicas, de maneira clara e evidente (clareza orçamentária). $\mathrm{O}$ orçamento bruto é regra intimamente ligada à universalidade orçamentária, já que prega pela impossibilidade de dedução dos recursos e apresentação do resultado na forma líquida. Porém, pelas mesmas razões já expostas, deve ser considerada como ínsita à universalidade orçamentária. 
Atualmente, a recomendação é que os três princípios tenham uma concepção doutrinária integrativa, até porque muitas vezes na doutrina os aspectos de um determinado princípio são utilizados para justificar ou esclarecer outro. A universalidade e unidade costumam ser a base que concede sustentação ao surgimento de outros princípios, como a não afetação. Assim, nesta concepção integrativa, as receitas e despesas públicas devem ser consideradas sob um liame lógico-orçamentário - seguindo uma unidade de desígnios (unidade) -, evitando-se contas apartadas ou paralelas ao orçamento (não afetação). Também devem ser concebidas na forma bruta como melhor técnica contábil, visto que deverão ser inscritas sem deduções, de forma clara e global (universalidade), sendo vedado o estabelecimento de ligações jurídicas (não afetação) que prejudiquem estas inscrições.

O princípio da não afetação é bem observado em outros ordenamentos, inclusive com inúmeras exceções. Os casos mais paradigmáticos dão-se na Lei Orgânica de 2001 da França, onde há diversas ressalvas com relação à sua aplicação. Este procedimento também ocorre na Espanha com o Texto refundido de la Ley Reguladora de las Haciendas Locales (TR-LRHL) e em Portugal com a Lei de Enquadramento Orçamental 91/2001.

Como a necessidade de flexibilidade costuma ser invocada em algumas regras jurídicas, a ideia de relativização ao princípio da não afetação - assim como à vinculação das receitas - costuma encontrar guarida na doutrina.

Neste sentido, as vinculações de receitas podem ser operacionalizadas de diversas formas ao mitigar o princípio da não afetação insculpido no ordenamento. No Brasil, os fundos específicos são os veículos mais utilizados para este fim. Assim, eles são instrumentos jurídicos que podem se prestar à afetação de recursos públicos, facilitando a identificação da fonte e destino preestabelecido e, consequentemente, a operacionalização destas verbas. Ressalve-se, entretanto, que isso não significa que todo fundo seja formado por recursos afetados. E os fundos de repartição de receitas entre entes federativos também não veiculam afetações, por não incluírem em seu escopo a destinação dos recursos (despesas).

A formação de fundos para a afetação de receitas de recursos naturais costuma ser aplaudida pela doutrina. Diante disto, muitos países acabam formando fundos extraorçamentários com recursos de petróleo, gás natural e minerais, muitas vezes na forma de fundos soberanos. Os fundos soberanos são vistos como uma forma de se evitar que os países dilapidem o patrimônio de recursos naturais - principalmente aqueles em desenvolvimento - e sejam displicentes no estoque de recursos para o futuro. Desta forma, com a formação de uma conta apartada, logra-se uma melhor gestão destes recursos. No 
Brasil, o Fundo Soberano do Brasil - FSB, surgido com a Lei $\mathrm{n}^{\circ}$ 11.887/08, veio com objetivo diverso daquele de preservar a renda auferida da exploração dos recursos naturais. Seu escopo vai além dos fundos soberanos existentes nas demais nações, dado que é composto por recursos orçamentários.

Um dos principais fundos constitucionais é o Fundo de Combate e Erradicação da Pobreza, instituído pela Emenda Complementar no 31/2000. Foi criado com o escopo de viabilizar programas sociais a fim de garantir o mínimo existencial, sofrendo críticas por parte da doutrina por desprestigiar os recursos orçamentários no que toca a esta alocação social de recursos. A exceção à derrogação da regra da não vinculação no artigo $80, \S 1^{\circ}$, do ADCT é somente ao IPI e ao IGF, e nas "demais receitas" do inciso IV do mesmo artigo não se incluiriam aquelas oriundas dos demais impostos, de forma que é dispensável a inserção deste último dispositivo no texto constitucional. Neste modelo, há também os Fundos de Combate à Pobreza estaduais, distrital ou municipais.

Existem igualmente os fundos estaduais e distrital de fomento à cultura, pelo qual também, com excesso de rigor, introduziu-se dispositivo vedando a utilização dos recursos vinculados a finalidade diversa. Por fim, na área da educação, existe o Fundo de Manutenção e Desenvolvimento da Educação Básica e de Valorização dos Profissionais da Educação.

Além dos fundos constitucionais, diversos diplomas introduziram fundos na sistemática financeira. Os principais fundos infraconstitucionais são o Fundo Penitenciário Nacional, o Fundo Especial de Assistência Financeira aos Partidos Políticos, o Fundo de Universalização dos Serviços de Telecomunicações e Fundo para o Desenvolvimento Tecnológico das Telecomunicações, Fundo Nacional da Cultura e Fundo da Marinha Mercante.

No Brasil, com a excessiva prática de afetação, houve o surgimento da concepção de uma norma desvinculadora de receitas. Esta tem sido a tendência nos governos mais recentes, dado o excessivo engessamento orçamentário com as receitas carimbadas. Outras nações, atentas a este risco, também passaram a desvincular parte de seu orçamento a fim de se garantir uma melhor gestão orçamentária em meados do século passado.

Já no Brasil, em razão da política fiscal de superávit primário adotada a partir de 1998, o nível de despesas discricionárias caiu sobremaneira nos últimos anos, o que impulsionou um movimento de reforma no sistema constitucional vigente. Inicialmente, concebeu-se o Fundo Social de Emergência para destinar recursos à educação e saúde, 
renomeado posteriormente como Fundo de Estabilização Fiscal. Este fundo originou, posteriormente, a Desvinculação de Receitas da União - DRU.

A Desvinculação de Receitas da União - DRU - transforma em recursos livres vinte por cento da arrecadação da União Federal com impostos e contribuições sociais e de intervenção no domínio econômico, influindo também, com o mesmo percentual, na base de cálculo das receitas afetadas e as despesas mínimas constitucionais - ressalvadas as exceções constitucionais -, podendo ser utilizados para formação de superávit primário.

$\mathrm{O} \S 3^{\circ}$ do artigo 76 do ADCT, introduzido pela Emenda Constitucional $n^{\circ}$ 59/09, veio a assegurar mais recursos para a educação ao reduzir a aplicação da DRU na base de cálculo dos recursos destinados à manutenção e desenvolvimento do ensino, mitigando a desvinculação de receitas. Porém, a redação do dispositivo poderia ter estabelecido taxativamente que a incidência da DRU sobre a base de cálculo do montante seria reduzida gradativamente, como ocorria no extinto Fundo Social de Emergência.

Apesar de parcela da doutrina entender que a cobrança de alguns tributos vinculados seria contrária à ordem jurídica em virtude desta desafetação, a tese não encontra guarida no ordenamento jurídico, principalmente em virtude do artigo $4^{\circ}$, II, do CTN. E também porque o artigo 76 do ADCT, ao mencionar a "arrecadação da União", não distingue cada tributo para a aplicação da DRU, mas sim o considera dentro da arrecadação tributária total das receitas desvinculadas.

Igualmente se discute a constitucionalidade da aplicação da DRU, visto que ela violaria os direitos e garantias individuais. Porém, a questão é que a vinculação não é bastante em si para garantir a concreção destes direitos, mas sim funciona como instrumento que pode incidentalmente auxiliar a sua efetivação, atuando juntamente com as políticas públicas para este fim. Somente a garantia de recursos não significa a efetivação destes direitos, afastando, portanto, a concepção de que estas vinculações funcionam como cláusula pétrea. Pode ser que haja, por exemplo, a desvinculação dos recursos sociais para aplicação em um setor social específico, o que dificultará a análise para determinar se tal ato estaria, ou não, eivado pela inconstitucionalidade. 


\section{BIBLIOGRAFIA}

Ahumada, Guillermo. Tratado de finanzas públicas. v. 3. Córdoba: Assandri, 1948.

ALEXANDER, Frank S. Financing affordable housing in Georgia: the possibility of a dedicated revenue source. Georgia State University Law Review. v. 13. p. 363-86. 1997.

ALMEIDA, José Barbosa de. Orçamento e política fiscal. Ensaio apresentado em concurso para a livre docência de Ciência das Finanças na Faculdade de Direito da Universidade de São Paulo. São Paulo: Max Limonad, 1964.

AnAStOPOUlos, Jean. Les aspects financiers du fédéralisme. Paris: L G D J, 1979.

ANDERSEN, Mikael Skou. Environmental and Economic Implications of Taxing and Trading Carbon: Some European Experiences. Vermont Journal of Environmental Law. v. 10. p. 61-85. 2008.

ANESI, Vincent. Earmarked taxation and political competition. Journal of Public Economics. v. 90. p. 679-701. 2006.

Antonini, Luca. Dal federalismo legislativo al federalismo fiscale. Rivista di Diritto Finanziario e Scienza delle Finanze. Milano. v. 63. n. 3. sett. 2004.

ARRETCHE, Marta. Quem taxa e quem gasta: a barganha federativa na federação brasileira. Revista de Sociologia e Política. São Paulo. n.24. jun. 2005, p. 81.

Assoni FiLho, Sérgio. Crédito público e responsabilidade fiscal. Porto Alegre: Nuria Fabris, 2007.

2009. Transparência fiscal e democracia. Porto Alegre: Nuria Fabris,

Ataliba, Geraldo. Apontamentos de ciência das finanças, direito financeiro e tributário. São Paulo: Revista dos Tribunais, 1969.

Destinação do produto da arrecadação de tributo - emenda Calmon

- despesas com educação. Revista dos Tribunais. São Paulo. v.75. n.612. p.18-26. out. 1986. Empréstimos públicos e seu regime jurídico. São Paulo: RT, 1973.

2005. Hipótese de Incidência Tributária. 6. ed. São Paulo: Malheiros,

Athanassakos, Alex. General fund financing versus earmarked taxes: an alternative model of budgetary choice in a democracy. Public Choice v. 66. p. 261-78. sept. 1990.

Auby, Jean-Marie; Ducos-AdER, Robert. Droit publique. 3. ed. Paris: Sirey, 1969.

BALeEIRO, Aliomar. Limitações Constitucionais ao Poder de Tributar. 5. ed. Rio de Janeiro: Forense, 1977. 
Uma introdução à ciência das finanças. 15. ed. Revista e atualizada por CAMPOS, Dejalma de. Rio de Janeiro: Forense, 1998.

Balthazar, Ezequiel Antonio Ribeiro. Fundos constitucionais como instrumento de redução das desigualdades regionais na federação. In: Conti, José Mauricio (org.). Federalismo fiscal. Barueri: Manole, 2004.

BANACloche Perez, Julio. Manual de economía financiera. Madrid: Derecho Financiero, 1971.

Bandeira de Mello, Celso Antônio. Curso de direito administrativo. 25. ed. São Paulo: Malheiros, 2008.

BARRERE, Alain. Institutions financières. 2. ed. t. I. Paris: Précis Dalloz, 1972. . Politique financière. Paris: Librairie Dalloz, 1958.

Bastos, Celso Ribeiro; Martins, Ives Gandra da Silva. Comentários à Constituição do Brasil. 6. v. t. II. São Paulo: Saraiva, 1991.

BAUdHuIN, Fernand. Précis de finances publiques. 4. ed. Bruxelles: E. Bruylant, 1966-68.

BeCKer, Alfredo Augusto. Teoria Geral do Direito Tributário. 2. ed. São Paulo: Saraiva, 1972.

BERCOVICI, Gilberto. Os princípios orçamentários e a primeira Constituição Republicana. Revista de Direito Internacional e Econômico Porto Alegre. n. 3. p. 80-86. abr./jun. 2003.

Bös, Dieter. Earmarked taxation: welfare versus political support. Journal of Public Economics. v. 75. p. 439-62. 2000.

Bouvier, Michel; Esclassan, Marie-Christine; LASSALE, Jean-Pierre. Finances Publiques. 7. ed. Paris: L.G.D.J., 2004.

Brasil. SECRETARIA De ORÇAmEnto Federal. Vinculações de Receitas dos Orçamentos Fiscal e da Seguridade Social e o Poder Discricionário de Alocação dos Recursos do Governo Federal. v. I. n. 1. Brasília: Secretaria de Orçamento Federal - SOF, 2003. Disponível em: http://www.planejamento.gov.br/secretarias/upload/Arquivos/sof/publicacoes/vinculacoes orcamentarias.pdf>. Acesso em: 9 fev. 2009.

Brett, Craig; KeEN, Michael. Political uncertainty and the earmarking of environmental taxes. Journal of Public Economics. v. 75. p. 315-40, 2000.

BREYNER, Frederico Menezes. Inconstitucionalidade da Desvinculação das Receitas da União (DRU) quanto às Contribuições Sociais sob a Ótica dos Direitos Prestacionais Fundamentais. 
Brochier, Hubert; TABATONI, Pierre. Économie financière. Paris: Presses universitaires de France, 1959.

Brosio, Giorgio; Gupta, Sanjeev. Ethiopia. In: Ter-Minassian, Teresa. (ed.). Fiscal federalism in theory and practice. Washington: International Monetary Fund, 1997, pp. 504-26.

Buchanan, James McGill. The economics of earmarked taxes. Journal of Political Economy. 71. n. 5. oct. p. 457-69, 1963.

BueHLER, Alfred Grether. Public finance. 3. ed. New York: McGraw-Hill, 1948.

Calvo Ortega, Rafael. Curso de derecho financiero. 7 ed. Madrid: Thomson Civitas, 2003.

CAMIC, Susannah. Earmarking: the potential benefits. Pittsburgh Tax Review. v. 4. p. 5584. 2006.

CAMPos, Dejalma de. Direito financeiro e orçamentário. 4. ed. São Paulo: Atlas, 2006.

CARREIRA, Liberato de Castro. Historia financeira e orçamentaria do imperio do Brazil desde a sua fundação, precedida de alguns apontamentos acerca da sua independência: Rio de Janeiro: Imprensa nacional, 1889.

CARrera Raya, Francisco José. Manual de derecho financiero. v. I. Madrid: Tecnos, 1994.

CARretero, Belén García. La financiación de las infraestructuras públicas de países en vías de desarrollo pero con una importante riqueza en recursos naturales: problemas y soluciones. In: Las nuevas fórmulas de financiación de infraestructuras públicas: LI Semana de Estudios de Derecho Financiero. Madrid: Ministerio de Economía y Hacienda - Instituto de Estudios Fiscales, 2008, p. 403-22.

CARTOU, Louis. Droit financier et fiscal européen. Paris: Dalloz, 1972.

CARvalho, André Castro. Racionalidade na alocação dos recursos públicos e o princípio da coerência no sistema tributário brasileiro. Revista Jurídica Tributária. v. 5. p. 221-257. abr./ jun. 2009.

Carvalho, José Augusto Moreira de. As Parcerias Público-Privadas e a atividade financeira do Estado. Dissertação (Mestrado em Direito) - Faculdade de Direito, Universidade de São Paulo, 2006.

Carvalho, Paulo de Barros. Curso de direito tributário. 17. ed. São Paulo: Saraiva, 2005.

CAsseb, Paulo Adib. Financiamento partidário: sistema público ou privado? IOBRepertório de Jurisprudência: tributário, constitucional e administrativo. São Paulo. n.13. p. 509-503. jul. 2002. 
CATÃo, Marcos André Vinhas. Novas perspectivas no princípio da não-afetação e destinação da receita tributária. In: PIRES, Adilson Rodrigues; TôRRES, Heleno Taveira (org.). Princípios de direito financeiro e tributário. Rio de Janeiro: Renovar, 2006, p. 56581 .

CAthelineau, Jean. Finances publiques: politique budgétaire et droit financier. Paris: Librairie générale de droit et de jurisprudence, 1975.

Cavalcanti, Amaro. Elementos de finanças: (estudo theorico:pratico). Rio de Janeiro: Imprensa nacional, 1896.

ChARBESKI, Heron. Desvio orçamentário de finalidade das contribuições à luz do federalismo fiscal brasileiro: o caso Cide-combustíveis. Revista Dialética de Direito Tributário. São Paulo. n. 128. mai. 2006.

Chu, Ke-young; NorregaArd, John. Korea. In: Ter-Minassian, Teresa. (ed.). Fiscal federalism in theory and practice. Washington: International Monetary Fund, 1997, pp. 540-69.

Clague, Ewan; Gordon, Jon. Earmarking tax funds for welfare purposes. Social Security Bulletin. n. 3. p. 10-20. jan. 1940.

ContI, José Mauricio. A Autonomia Financeira do Poder Judiciário. São Paulo: MP Editora, 2006.

Da proposta orçamentária. In: CoNTI, José Mauricio (coord.). Orçamentos públicos: a Lei 4.3620/1964 comentada. São Paulo: Revista dos Tribunais, 2008, p. 87-120.

Mendes, 1998. Direito financeiro na Constituição de 1988. São Paulo: Oliveira Oliveira, 2001. Federalismo fiscal e fundos de participação. São Paulo: Juarez de

CORTI, Horacio Guillermo. Derecho constitucional presupuestario. Buenos Aires: Lexis Nexis Argentina, 2007. . Derecho financiero. Buenos Aires: Abeledo-Perrot, 1997.

Cosciani, Cesare. Scienza delle Finanze. A cura di BISES, Bruno et al. Con il coordinamento di CAMPA, Giuseppe. Torino: UTET, c2009.

Cossa, Luigi. Primi elementi di scienza delle finanze. 9. ed. Milano: U. Hoepli, 1905.

Costa, Eunice. Vinculação da receita: transferência, possibilidade. Revista de Direito Publico. São Paulo. v.24. n.97. p. 259-62. jan./mar. 1991.

CRETella Júnior, José. Comentários à Constituição Brasileira de 1988. Rio de Janeiro: Forense, 1989. Do desvio de poder. São Paulo: RT, 1964.

Dalton, Hugh. Princípios de Finanças Públicas. 2. ed. Trad. de Modiano, Maria de Lourdes. Rio de Janeiro: GB, 1970. 
De Plácido e Silva, Oscar José. Noções de finanças e direito fiscal. 2. ed. São Paulo: Guaíra, s.a. Vocabulário Jurídico. 15. ed. Revista e atualizada por SLAIBI FILHO, Nagib; ALVES, Geraldo Magela. Rio de Janeiro: Forense, 1998.

Del Federico, Lorenzo. Tributi Paracommutativi e finanziamento dei servizi pubblici. Caso italiano e prospettive europee. Rivista di Diritto Finanziario e Scienza delle Finanze. Milano. v.62. n.2. 2003.

Deodato, Alberto. Manual de ciência das finanças. 13. ed. São Paulo: Saraiva, 1973.

Derzi, Misabel de Abreu Machado. Arts. 40 a 47. In: Martins, Ives Gandra da Silva; Nascimento, Carlos Valder do (org.). Comentários à Lei de Responsabilidade Fiscal. 2. ed. São Paulo: Saraiva, 2007, p. 258-344.

DÓRIA, Antônio Roberto Sampaio. Discriminação de rendas tributárias. São Paulo: J. Bushatsky, 1972.

Du MERIL, Édélestand. Philosophie du budget. Paris: Chez Heideloff et Campé, 1838.

DuARTE, Manoel. Questões de finanças. Coimbra: Francisco França Amado Editor, 1893.

DufF, David G. Benefit Taxes and User Fees in Theory and Practice. v. 54. The University of Toronto Law Journal. p. 391-448. 2004.

DuVErger, Maurice. Finances publiques. Paris: Presses Universitaires de France, 1950.

EINAUdI, Luigi. Principios de hacienda publica. 6. ed. Trad. de AlgarRa, Jaime; PAREDES, Miguel. Madrid: Aguilar, 1962.

Ellwood, John W.; Sprague, Mary. Options for Reforming the California State Budget Process. [s.1.]: [s.n.], 19--. Disponível em: http://igs.berkeley.edu/library/htConstReform2003-ELLWOODtext.pdf. Acesso em: 28 fev. 2009.

Ely, Bruce P.; Walthall, Howard P. State constitutional limitations on taxing and spending: a comparison of the Alabama Constitution of 1901 to its counterparts. Cumberland Law Review. v. 33. p. 463-512. 2003.

FALCÓN Y TELlA, Ramón. Introducción al derecho financiero y tributario de las comunidades europeas. Madrid: Civitas, 1988.

FENNEL, Lee Anne. Death, taxes, and cognition. North Carolina Law Review. v. 81. p. 567652. 2003.

FERRAZ JÚNIOR, Tércio Sampaio. Introdução ao Estudo do Direito. 4. ed. São Paulo: Atlas, 2003. 
Figueiredo, Carlos Maurício et al. Comentários à Lei de Responsabilidade Fiscal. 2. ed. São Paulo: RT, 2001.

FIGUEIRÊDO, Elpidio. Principios elementares da sciencia das finanças. Recife: Diário de Pernambuco, 1909.

Fonrouge. Carlos M. Giuliani. Derecho financiero. v. I e II. 3. ed. Buenos Aires: Ediciones Depalma, 1977.

FrAnCo Sobrinho, Manuel de Oliveira. O controle da moralidade administrativa. São Paulo: Saraiva, 1974.

Franco, Gabriel. Principios de hacienda pública. Madrid: Derecho Financiero, 1967.

FrANCO, Gustavo. Vinculações. [s.1.]: 2000. Disponível em: <http://www.econ.pucrio.br/gfranco/a76.htm>. Acesso em: 16 out. 2008.

FreITAS, Juarez. Parcerias Público-Privadas (PPPs): características, regulação e princípios. Interesse Público. Sapucaia do Sul, RS. v.5. n.29. p.13-61. jan./fev. 2005.

FURTADO, José de Ribamar Caldas. O problema da vinculação de recursos orçamentários. Fórum de Contratação e Gestão Pública. Belo Horizonte. v.6. n.70. p.48-54. out. 2007.

GANGEMI, Lello. Sistemi finanziari comparati. t. I e II. Torino: Utet, 1967.

GARCÍA, Gloria Alarcón. Financiación privada de obras públicas. In: FUNDACIÓN PARA LA PROMOCIÓN DE LOS ESTUDIOS FINANCIEROS. Las nuevas fórmulas de financiación de infraestructuras públicas: LI Semana de Estudios de Derecho Financiero. Madrid: Ministerio de Economía y Hacienda - Instituto de Estudios Fiscales, 2008, p. 87-108.

GARZA, Sergio Francisco de la. Derecho financiero mexicano. 4. ed. México: Editorial Porrúa, 1969.

Gaudemet, Yves. Droit administratif. 18. ed. Paris: L.G.D.J., 2005.

Giacomoni, James. Orçamento Público. 14. ed. São Paulo: Atlas, 2007.

Giambiagi, Fabio; AlÉm, Ana Cláudia. Finanças públicas. 3. ed. Rio de Janeiro: Elsevier, 2008.

GIANNINI, Achille Donato. Elementi di diritto finanziario. Milano: Giuffrè, 1945.

GoMES, Emerson Cesar da Silva. Da contabilidade. In: CONTI, José Mauricio (coord.). Orçamentos públicos: a Lei 4.3620/1964 comentada. São Paulo: Revista dos Tribunais, 2008, p. 248-347.

GreCo, Marco Aurélio. A destinação dos recursos decorrentes da contribuição de intervenção no domínio econômico. Revista Dialética de Direito Tributário. São Paulo. n.104. p.122-40. maio. 2004. 
; Ferraz Júnior, Tércio Sampaio. Desafios do federalismo físcal brasileiro. Revista do Instituto dos Advogados de São Paulo. São Paulo. v.1. n.2. p. 97-104. jul./dez. 1998.

GriJALBA, Miguel Angoitia. Il financiamento degli enti locali in Spagna. Rivista di Diritto Finanziario e Scienza delle Finanze. Milano. v.62. n.4. p.498-537. dic. 2003.

Griziotti, Benvenuto. Principios de ciencia de las finanzas. 6. ed. Atualizada por Forte, Francesco. Trad. de JARACH, Dino. Bueno Aires: Roque Depalma Editor, 1959.

GROENENDIJK, Nico. Budgetary discipline in Brussels: numerical targets or procedural rules? Pittsburgh: ECSA Sixth Biennial International Conference, 1999. Disponível em: $<$ <ttp://aei.pitt.edu/2279/01/002627_1.PDF>. Acesso em: 20 out. 2008.

Haller, Heinz. Política Financiera. Trad. de Moreno, Fernando Sáinz. Madrid: Ed. de Derecho Financiero, 1963.

HaRADA, KiYOSHI. Direito financeiro e tributário. 10. ed. São Paulo: Atlas, 2002. - Operações de crédito e vinculação de receitas tributárias. [São Paulo]: [s.n.], 2002. Disponível em: $<$ http://www.fiscosoft.com.br/main_index.php?home=home_artigos\&m=_\&nx_=\&viewid $=98536>$. Acesso em: 16 out. 2008.

. Parceria público-privada - vinculação de receitas - instituição de fundos especiais - art. $8^{\circ}$, incs. I e II, da lei n. 11.079/04 - inconstitucionalidade (parecer): Boletim de Direito Administrativo. São Paulo. v.21. n.3. p.308-15. mar. 2005 . Responsabilidade fiscal: lei complementar n. 101/2000 comentada e legislação correlata anotada. São Paulo: Juarez de Oliveira, 2002. Vinculação pelo Município das cotas do ICMS para garantia de operações de crédito: efeitos. IOB-Repertório de Jurisprudência: tributário, constitucional e administrativo. São Paulo. n.2. p. 96-93. jan. 1999.

Holanda Ferreira, Aurélio Buarque de. Novo Dicionário da Língua Portuguesa. 2. Ed. Rio de Janeiro: Nova Fronteira, 1986.

Horvath, Estevão. A Constituição e a Lei Complementar n ${ }^{\circ}$ 101/2000 ("Lei de Responsabilidade Fiscal"). Algumas Questões: In: RoCHA, Valdir de Oliveira. Aspectos relevantes da Lei de Responsabilidade Fiscal. São Paulo: Dialética, 2001, p. 149-62.

Houaiss, Antonio; Villar, Mauro de Salles. Dicionário Houaiss da Língua Portuguesa. Rio de Janeiro: Objetiva, 2001.

IBRAHIM, Fábio Zambitte. Desvinculação parcial da arrecadação de imposto e contribuições: uma interpretação possível da Emenda Constitucional $\mathrm{n}^{\mathbf{0}} 27$. Revista Dialética de Direito Tributário. São Paulo. n.61. p.43-8. out. 2000.

INGROSSO, Giovanni. Corso di finanza pubblica. Napoli: Jovene, 1969.

JARACH, Dino. Finanzas Públicas y Derecho Tributario. Buenos Aires: Cangallo, 1993. 
JARAMILlo, Esteban. Tratado de ciencia de la hacienda pública. 2. ed. Bogotá: Minerva, 1930.

JARDIM, Eduardo Marcial Ferreira. Manual de direito financeiro e tributário. 2. ed. São Paulo: Saraiva, 1994.

JESUS, Wellington Ferreira de. "Despesa sagrada": estudo sobre a vinculação constitucional de verbas para a educação nas Constituições Brasileiras de 1934 e 1946. Dissertação (Mestrado em Educação) - Universidade Católica de Brasília, 2007.

JÈZE, Gaston Paul Amédée. Cours de finances publiques. Paris: Giard, 1928. - Cours de science des finances et de législation financière française. 6. ed. Paris: Marcel Giard, 1922. Traité de science des finances. Paris: V. Giard \& E. Brière, 1910.

JouAniQue, Pierre. Budget de l'état. Paris: Centre de Documentation Universitaire, 1947.

JuAno, Manuel de. Curso de finanzas y derecho tributario. t. III. Rosario: Molachino, 1964.

Kelsen, Hans. Teoria pura do direito. Trad. de MACHADO, João Baptista. São Paulo: Martins Fontes, 2000.

KHAIR, Amir Antônio. Lei de Responsabilidade Fiscal: as transgressões à Lei de Responsabilidade Fiscal e correspondentes punições fiscais e penais. Brasília: MPOG/BNDES/ENAP, 2000.

LACERDA, Sander Magalhães. O financiamento da infra-estrutura rodoviária através de contribuintes e usuários. BNDES Setorial. Rio de Janeiro. n. 21. p. 141-159. mar. 2005.

LAFERRIÈRE, Julien; WALINE, Marcel. Traité élémentaire de science et de législation financières. Paris: Librairie générale de droit et de jurisprudence, 1952.

LAPATZA, José Juan Ferreiro. Curso de derecho financiero español. 24. ed. Madrid: Marcial Pons, 2004.

LAUFENBURGER, Henry. Traité d'économie et de législation financieres: budget et Trésor. 3. ed. Paris: Sirey, 1948. Finances comparées. 2. ed. Paris: Recueil Sirey, 1950

MARSILIANI, Laura; RENSTRÖM, Thomas I. Time inconsistency in environmental policy: tax earmarking as a commitment solution. The Economic Journal. v. 110. p. C123-C138. mar. 2000.

MARTINS, Cláudio. Compêndio de finanças públicas. São Paulo: Bushatsky, 1976.

MARTIns, Vinicius Aversari; ANDRAdE, Maria Elisabeth Moreira Carvalho. Contabilidade de contratos de parcerias público-privadas: uma abordagem à luz das normas internacionais do IASB. Contabilidade, Gestão e Governança. Brasília. v. 12. n. 1. p. 1023. jan/abr. 2009. 
MATIAS-PereIRA, José. Finanças públicas: a política orçamentária no Brasil. 3. ed. São Paulo: Atlas, 2006.

Maximiliano, Carlos. Hermenêutica e Aplicação do Direito. Rio de Janeiro: Forense, 2000.

MCCLEARY, William. The earmarking of government revenue: a review of some World Bank Experience. The World Bank Research Observer. v. 6. n. 1. p. 81-104. jan. 1991.

McGeE, Robert W. Principles of Taxation for Emerging Economies: Lessons from the U.S. Experience. Dickinson Journal of International Law. v. 12. p. 29-94. 1993-94.

.Some Tax Advice for Latvia and Other Similarly Situated Emerging

Economies. International Tax \& Business Law. v. 13. p. 223-308. 1995-1996.

MeIRELles, Hely Lopes. Direito administrativo brasileiro. 32. ed. Atualizada por Azevedo, Eurico de Andrade; AleiXo, Décio Balestero; Burle Filho, José Emmanuel. São Paulo: Malheiros, 2006.

Finanças municipais. São Paulo: RT, 1979.

Mendes, Marcos José. A eficácia da vinculação de recursos no federalismo brasileiro: o caso do FUNDEF. Brasília: Secretaria do Tesouro Nacional. VIII Prêmio Tesouro Nacional, 2003. Disponível em: $<$ http://www.tesouro.fazenda.gov.br/Premio_TN/VIIPremio/financas/1tefpVIIPTN/mendes .pdf>. Acesso em: 16 out. 2008.

Federalismo fiscal. In: ARVATE, Paulo Roberto; BIDERMAN, Ciro (org.). Economia do setor público no Brasil. Rio de Janeiro: Elsevier, 2004, p. 421-61.

MERESSI, Fernando Sertã. Macrodinâmica do orçamento. Brasília: [s.n], 2006. Disponível em: <http://www.assecor.org.br/v2/documentos/Macrodinamica_do_Orcamento.pdf $>$. Acesso em: 27 fev. 2009.

MiLESKI, Helio Saul. O controle da gestão pública. São Paulo: RT, 2003.

Moncada, Luís S. de Cabral. Perspectivas do novo direito orçamental português. Coimbra: Coimbra Editora, 1984.

Monteiro, Vera. Legislação de Parceria Público-Privada no Brasil - aspectos fiscais desse novo modelo de contratação. In: SundFELD, Carlos Ari (coord.). Parcerias PúblicoPrivadas. São Paulo: Malheiros, 2005, p. 80-113.

MoYe, Marcel. Précis élémentaire de législation financière: a l'usage des étudiants des facultés de droit: Paris: Larose \& Forcel, 1905.

Musgrave, Richard Abel. Musgrave, Peggy B. Hacienda publica teorica y aplicada. 2. ed. Trad. de LozAno IRUESTE, José María. Madrid: Inst. de Estudios Fiscales, 1983.

- Teoria das Finanças Públicas: um estudo de economia governamental. v. I. Trad. de SIMÕES, Auriphebo Berrance. São Paulo: Atlas, 1973. 
MuZELLEC, Raymond. Notions essentielles de finances publiques: concours administratifs catégorie A, C.P.A.G.-I.R.A. Paris: Sirey, 1976.

Nascimento, Carlos Valder do. Curso de direito financeiro. Rio de Janeiro: Forense, 1999.

NitTI, Francesco Saverio. Princípios da ciência das finanças. 2. v. Trad. de Machado, C. Rio de Janeiro: Atena, 1937.

Nunes, Cleucio Santos. Dos fundos especiais. In: In: ConTI, José Mauricio (coord.). Orçamentos públicos: a Lei 4.3620/1964 comentada. São Paulo: Revista dos Tribunais, 2008, p. 204-21.

OliveIrA, Austen da Silva. Aspectos constitucionais e legais do orçamento público. Dissertação (Mestrado em Direito) - Faculdade de Direito, Universidade de São Paulo, 1979.

OliveIRA, José Marcos Domingues de. Meio-ambiente - tributação e vinculação de impostos. Revista de Direito Tributário. São Paulo. v.15. n.56. p. 84-91. abr./jun. 1991.

OliveIRA, Regis Fernandes de. Curso de direito financeiro. 2. ed. São Paulo: Revista dos Tribunais, 2008. . Responsabilidade fiscal. 2. ed. São Paulo: RT, 2002.

PAMPlona, Karla Marques. Contribuição parafiscal como instrumento de política fiscal em prol dos direitos humanos. [s.1.]: [s.n.], [20--]. Disponível em: $<$ http://www.conpedi.org/manaus/arquivos/Anais/Karla\%20Marques\%20Pamplona.pdf $>$.

Acesso em 16 out. 2008.

PAYSANT, André. Finances publiques. 2. ed. Paris: Masson, 1988.

PAZZAGlini Filho, Marino. Crimes de responsabilidade fiscal: atos de improbidade administrativa por violação da LRF. 3. ed. São Paulo: Atlas, 2006.

PÊGo FILHO, Bolívar; CÂNDIDO JÚNIOR, José Oswaldo; PEREIRA, Francisco. Investimento $e$ financiamento da infra-estrutura no Brasil: 1990/2002. Brasília: [s.n.], 1999. Disponível em: <http://www.ipea.gov.br/pub/td/td_99/td_680.pdf>. Acesso em: 31 ago. 2008.

Penner, Rudolph G.; Koch, Julianna. How Much Federal Spending Is Uncontrollable? Tax Notes - The Tax Policy Center, the Urban Institute and Brookings Institution. 16 jul. 2007, p. $195 . \quad$ Disponível em: <http://www.taxpolicycenter.org/UploadedPDF/1001093_federal_spending_uncontrollable .pdf>. Acesso em: 28 mar. 2009.

PÉREZ RoYo, Fernando. Derecho financiero y tributario: parte general. 9. ed. Madrid: Civitas, 1999.

PIERSON, Paul. Increasing returns, path dependence, and the study of Politics. American Political Science Review. v. 94. n. 2. p. 251-67. jun. 2000. 
Pinto Ferreira, Luis. Comentários à Constituição Brasileira. 6. v. São Paulo: Saraiva, 1994.

Plazas Vega, Mauricio Alfredo. Los tributos vinculados. Revista Estudios SocioJurídicos. Santa Fé de Bogotá. v.2. n.1. p. 97-172. mar. 2000.

PLEHN, Carl Copping. Introduction to public finance. New York: The Macmillan company, 1931.

PoLLARI, Nicolò. Scienza delle finanze. Roma: Laurus Robuffo, 1995.

Pontes de Miranda, Francisco Cavalcanti. Comentários à Constituição de 1967: com a Emenda $n^{o}$ 1, de 1969. t. III. 2. ed. São Paulo: Revista dos Tribunais, 1971.

PRADO, Sérgio. Equalização e federalismo fiscal: uma análise comparada. Rio de Janeiro: Konrad-Adenauer-Stiftung, 2006.

PREST, Alan Richmond. Public finance in underdeveloped countries. New York: Praeger, [1963, c1962]

QuesadA, Sixto J. Las finanzas de la República Argentina. Buenos Aires: Impr. M. Biedma, 1892.

RAUTAVA, Jouko. Sovereign wealth funds arouse political passions. Focus/Opinion: Expert view. Bank of Finland - Institute for Economies in Transition, BOFIT. n. 2. 14 abr. 2008

RibeIro, Mauricio Portugal; Prado, Lucas Navarro. Comentários à Lei de PPP Parceria Público-Privada: fundamentos econômico-jurídicos. São Paulo: Malheiros, 2007.

REGUERA, Emilia Girón. La financiación autonómica del sistema constitucional español. Cádiz: Universidad, Servicio de Publicaciones, 2003.

REZENDE DA SILVA, Fernando Antonio. Brasil: conflitos federativos e reforma tributária. In: REZENDE DA SILVA, Fernando Antonio (coord.). Desafios do federalismo fiscal. Rio de Janeiro: Editora FGV, 2006, pp. 83-114.

Os desafios do federalismo fiscal. In: REZENDE DA SILVA, Fernando Antonio (coord.). Desafios do federalismo fiscal. Rio de Janeiro: Editora FGV, 2006, pp. $11-23$.

RIVOLI, Jean. Le budget de l'État. Paris: Éditions du Seuil, 1969.

RochA, Ariosto de Rezende. Rendas gravadas. Manaus: Faculdade de Direito do Amazonas, 1954.

Rodriguez Rossi, Victor Ernesto. El crédito público: efectos y empleo. Buenos Aires: Abeledo Perrot, 1981.

Rossy, Hipólito. Instituciones de derecho financiero. Barcelona: Distribución Librería Bosch, 1959. 
RoTH, Gabriel. Roads in a Market Economy. Aldershot: Ashgate, 1996.

RoviRa Mola, Alberto de. Los fondos fiscales con finalidad redistributiva. Madrid: Inst. de Estudios de Administración Local, 1976.

RYCHLAK, Ronald J. Lotteries, revenues and social costs: a historical examination of statesponsored gambling. Boston College Law Review. v. 34. p. 11- 82. dec. 1992.

SAEnZ, Mario. Presupuesto nacional. Buenos Aires: Cuadernos Radicales, 19--.

SAINZ De Bujanda, Fernando. Notas de derecho financiero. Seminario de derecho financiero. Tomo I: introducción y parte general. v. III. Madrid: Universidad de Madrid, 1975.

SAntos JúnIOR, Francisco Alves dos. Curso de direito financeiro. Campinas: Bookseller, 2006.

SAY, León. Dictionnaire des finances. Paris: Berger-Levrault et Cie, 1889.

SCAFF, Fernando Facury. As contribuições sociais e o princípio da afetação. Revista Dialética de Direito Tributário. São Paulo. n.98. p.44-62. nov. 2003.

.Direitos humanos e a desvinculação das receitas da União

- DRU. Revista de Direito Administrativo. Rio de Janeiro. n.236. p.33-50. abr./jun. 2004.

Para além dos direitos fundamentais do contribuinte: o

STF e a vinculação das contribuições. In: SCHOUERI, Luís Eduardo (coord.). Direito tributário: homenagem a Alcides Jorge Costa. v. II. São Paulo: Quartier Latin, 2003, p. 1125-46.

SeIXAs Filho, Aurélio Pitanga. A integralidade orçamentária e as contribuições. Revista Tributária e de Finanças Públicas. São Paulo. v.12. n.59. p.209-23. nov./dez. 2004.

SenNA, Luiz Afonso dos Santos; Michel, Fernando Dutra. Rodovias auto-sustentadas: o desafio do século XXI. São Paulo: Editora CLA, 2006.

SERRANO, Luís Sánchez. Tratado de derecho financiero y tributario constitucional. t. I. Madrid: Marcial Pons, 1997.

Silva, José Afonso da. Curso de direito constitucional positivo. 23. ed. São Paulo: Malheiros, 2004. Orçamento-programa no Brasil. São Paulo: RT, 1973. Tributos e normas de política fiscal na Constituição do Brasil.

São Paulo: s.n., 1968

SILVA, Mauro Santos. Vinculações de receitas não financeiras da União. In: VIII Congreso Internacional del CLAD sobre la Reforma del Estado y de la Administración Pública. Panamá: [s.n.], 28-31 oct. 2003. Disponível em: $<$ http://unpan1.un.org/intradoc/groups/public/documents/CLAD/clad0047828.pdf>. Acesso em: 11 mar. 2009. 
SILVA, Sebastião de Sant'Anna e. Os princípios orçamentários. Rio de Janeiro: Fundação Getúlio Vargas, Serviço de Publicações, 1962.

Silva, Virgílio Afonso da. Princípios e regras: mitos e equívocos acerca de uma distinção. Revista Latino-Americana de Estudos Constitucionais. n. 1. p. 607-30. 2003.

SIMÕES, José Martinho. Finanças. Coimbra: Neves, 1920.

Simonson, Kenneth D. Fuel taxes, federal. In: CoRDES, Joseph J.; Ebel, Robert D.; Gravelle, Jane G. (editors). The encyclopedia of taxation \& tax policy. 2. ed. Washington, D.C: Urban Institute Press, 2005, p. 162-64.

SMART, L. Edwin; HART, John N. The Distribution of Revenues from State-Collected Consumer Taxes. Law \& Contemporary Problems. v.8. p. 463-81, 1941.

Sousa Franco, Antonio Luciano de. Manual de finanças públicas e direito financeiro. v. I. Lisboa: S. N., 1974.

STEFANI. Alberto de. Manuale di finanza. Bologna: Nicola Zanichelli, 1943.

STERK, Stewart. Environmental Review in the Land Use Process: New York's Experience with SEQRA. Cardozo Law Review. v. 13. p. 2041-96. 1991-1992.

STEWART, Richard B. Environmental Regulation and International Competitiveness. The Yale Law Journal. v. 102. p. 2039-136. 1993.

STOURM, René. Le budget: son histoire et son mécanisme. Paris: Guillaumin, 1889.

StUber, Walter Douglas. O financiamento de projetos no Brasil e a lei de concessões. São Paulo: Max Limonad, 1996.

SundELSON, Jacob Wilner. Budgetary principles. Political Science Quarterly. v. 50. n. 2. jun. 1935 , p. 236-63.

SundFeld, Carlos Ari. Guia Jurídico das Parcerias Público-Privadas. In: SundFELD, Carlos Ari (coord.). Parcerias Público-Privadas. São Paulo: Malheiros, 2005, p. 15-44.

TeIXEIRA RIBEIRO, José Joaquim. Lições de finanças públicas. 5. ed. Coimbra: Coimbra Ed., 1997.

TORRES, Ricardo Lobo. Curso de Direito Financeiro e Tributário. 8. ed. Rio de Janeiro: Renovar, 2001.

Tratado de direito constitucional financeiro e tributário. v. 5: o orçamento na Constituição. 3. ed. Rio de Janeiro: Renovar, 2008.

Trotabas, Louis; CotTeret, Jean-Marie. Droit budgétaire et comptabilité publique. 5. ed. avec la collaboration de LAFLANDRE, Michel. Paris: Dalloz, 1995.

Marie. 3. ed. Paris: Dalloz, 1969.

. Finances publiques. avec la collaboration de COTTERET, Jean- 
VALDÉS, José Andrés Rozas. Una aproximación a la financiación de autopistas, desde la experiencia española. In: TôRRES, Heleno Taveira. Serviços públicos e direito tributário. São Paulo: Quartier Latin, 2005, p. 563-610.

VARSANO, Ricardo; FERREIRA, Sérgio Guimarães; AFONSO, José Roberto. Fiscal competition: a Bird's eye view. Texto para discussão n. 887. Rio de Janeiro: IPEA, 2002.

VeIga Filho, João Pedro da. Manual da sciencia das finanças. 2. ed. São Paulo: Espindola, 1906.

Venosa, Sílvio de Salvo. Direito civil. 5. ed. v. 5. São Paulo: Atlas, 2005.

ViannA, Geraldo Aguiar de Brito. O mito do rodoviarismo brasileiro. 2. ed. São Paulo: NTC\&Logística, 2007.

Villarejo, Avelino García; SÁncheZ, Javier Salinas. Manual de hacienda publica. General y de España. Madrid: Tecnos, 1985.

VILlEGaS, Hector Belisario. Curso de finanzas, derecho financiero y tributario. Con la colaboración de PALACIO, Eduardo S. Caieiro. 9. ed. Buenos Aires: Editorial Astrea, 2007.

WADDINGTON, Catriona. Does earmarked donor funding make it more or less likely that developing countries will allocate their resources towards programmes that yield the greatest health benefits? Bulletin of the World Health Organization [online]. v. 82. n. 9. Genève. p. 703-706. sept. 2004. Disponível em: $<$ http://www.scielosp.org/scielo.php?pid=S004296862004000900013\&script=sci_arttext $>$. Acesso em: 20 out. 2008.

WILKINSON, Margaret. Paying for public spending: is there a role for earmarked taxes? Fiscal Studies. v. 15. n. 5. p. 119-35. nov. 1994.

WYRICK, Thomas L.; ARNOLD, Roger A. Earmarking as a deterrent to rent-seeking. Public Choice. v. 60. p. 283-91. mar. 1989. 


\section{ÍNDICE LEGISLATIVO E OUTRAS FONTES}

AlemanHA. Grundgesetz für die Bundesrepublik Deutschland. Disponível em: < http://www.gesetze-im-internet.de/bundesrecht/gg/gesamt.pdf>. Acesso em: 7 abr. 2010.

ArgEntinA. Ley $\mathrm{n}^{\text {o }}$ 24.156, de 30/9/1992. Disponível em: $<$ http://www.infoleg.gov.ar/infolegInternet/anexos/0-4999/554/norma.htm>. Acesso em: 7 out. 2008.

. Constitución de la Nación Argentina de 1994. Disponível em: $<$ http://www.argentina.gov.ar/argentina/portal/documentos/constitucion_nacional.pdf $>$. Acesso em: 16 out. 2008.

BolíviA. Nueva Constitución Política del Estado de 2008. Disponível em: <http://www.mindef.gov.bo/mindef/node/28>. Acesso em: 7 abr. 2010.

BRASIL. Constituicão Politica do Imperio do Brazil de 1824. Disponível em: $<$ http://www.planalto.gov.br/ccivil_03/constituicao/constitui\%C3\%A7ao24.htm $>$. Acesso em: 20 out. 2008.

Disponível Constituição da República Federativa do Brasil de 1967. $<$ http://www planalto gov br/ccivil 03/constituicao/Constitui\%C3\% A7ao67 htm> Acesso em: 20 out. 2008.

Disponível Constituição da República Federativa do Brasil de 1988. $<$ http://www.planalto.gov.br/ccivil_03/constituicao/constitui\%C3\%A7ao.htm>. Acesso em: 20 out. 2008.

. Decreto $\mathrm{n}^{\circ} 4.129$, de 13 de fevereiro de 2002. Disponível em: $<$ http://www.planalto.gov.br/ccivil_03/decreto/2002/D4129.htm>. Acesso em: 20 out. 2008.

. Decreto-lei $\mathrm{n}^{\circ} 1.437$, de 17 de dezembro de 1975. Disponível em: <https://www.planalto.gov.br/ccivil_03/decreto-lei/del1437.htm>. Acesso em: 12 abr. 2010 .

. Decreto-lei $n^{\circ} 2.848$, de 7 de dezembro de 1940. Disponível em: <http://www.planalto.gov.br/CCIVIL/Decreto-Lei/Del2848.htm>. Acesso em: $12 \mathrm{abr}$. 2010 .

. Decreto-lei no 201, de 27 de fevereiro de 1967. Disponível em: $<$ http://www.planalto.gov.br/ccivil_03/Decreto-Lei/Del0201.htm $>$. Acesso em: 12 abr. 2010.

Decreto-lei no 8.463, de 27 de dezembro de 1945.

. Emenda Constitucional $\mathrm{n}^{\mathrm{o}}$ 1, de 1969. Disponível em:

$<$ http://www.planalto.gov.br/ccivil_03/constituicao/Emendas/Emc_anterior1988/emc0169.htm>. Acesso em: 20 out. 2008.

- Exposição de Motivos Interministerial $\mathrm{n}^{\mathrm{o}}$ 106/MOG/MF/MPAS, de 13 de abril de 1999. Disponível em: $<$ http://www.planalto.gov.br/ccivil_03/revista/Rev_01/EM-PLC18.htm>. Acesso em 25 jun. 2009. 
. Exposição de Motivos n ${ }^{\circ}$ 355/2003/MP/MF, de 10 de <http://www.camara.gov.br/sileg/integras/182910.pdf>. Acesso em: 20 out. 2008.

. Lei Complementar Federal $n^{\circ} 101$, de 4 de maio de 2000. Disponível em: <http://www.planalto.gov.br/ccivil_03/Leis/LCP/lcp101.htm>. Acesso em: 20 out. 2008.

. Lei Complementar Federal no 79, de 7 de janeiro de 1994. Disponível em: <http://www.planalto.gov.br/ccivil_03/Leis/LCP/Lcp79.htm>. Acesso em: 20 out. 2008.

Lei Estadual $\mathrm{n}^{\mathrm{o}} 11.477$, de 1 de julho de 2009 do Estado da Bahia. Disponível em: <http://www.jusbrasil.com.br/legislacao/818276/lei-11477-09bahia-ba>. Acesso em: 14 ago. 2009.

. Lei Estadual $\mathrm{n}^{\circ}$ 12.298, de 8 de março de 2006 do Estado de São Paulo. Disponível em: <http://www.legislacao.sp.gov.br/dg280202.nsf/ae9f9e0701e533aa032572e6006cf5fd/2f75 6ec5d48cbaa3032571300044e991? OpenDocument>. Acesso em: 7 abr. 2010.

. Lei Federal $n^{\circ} 10.052$, de 28 de novembro de 2000. Disponível em: <http://www.planalto.gov.br/ccivil_03/leis/L10052.htm>. Acesso em: 20 out. 2008.

. Lei Federal $\mathrm{n}^{\circ} 10.052$, de 28 de novembro de 2000. Disponível em: <http://www.planalto.gov.br/CCIVIL/Leis/L10052.htm>. Acesso em: 12 abr. 2010.

Lei Federal no 10.260, de 12 de julho de 2001. Disponível em: $<$ http://www.planalto.gov.br/ccivil_03/Leis/LEIS_2001/L10260.htm>. Acesso em: $12 \mathrm{abr}$. 2010 .

. Lei Federal no 11.079, de 30 de dezembro de 2004. Disponível em: <http://www.planalto.gov.br/ccivil_03/_ato2004-2006/2004/Lei/L11079.htm>. Acesso em: 20 out. 2008.

. Lei Federal $n^{\circ} 11.494$, de 20 de junho de 2007. Disponível em: $<$ http://www.planalto.gov.br/ccivil/_Ato2007-2010/2007/Lei/L11494.htm>. Acesso em: 12 abr. 2010.

. Lei Federal $n^{\circ} 11.887$, de 24 de dezembro de 2008. Disponível em: <http://www.planalto.gov.br/CCIVIL/_Ato2007-2010/2008/Lei/L11887.htm>. Acesso em: 10 abr. 2010.

. Lei Federal $\mathrm{n}^{\mathrm{o}}$ 12.202, de 14 de janeiro de 2010. Disponível em: $\quad<$ http://www.planalto.gov.br/ccivil_03/_Ato2007-2010/2010/Lei/L12202.htm>. Acesso em: 12 abr. 2010.

. Lei Federal no 3.381, de 24 de abril de 1958. Disponível em: $<$ http://www.planalto.gov.br/ccivil_03/Leis/1950-1969/L3381.htm>. Acesso em: 10 abr. 2010.

. Lei Federal no 4.320, de 17 de março de 1964. Disponível em: $<$ http://www.planalto.gov.br/ccivil_03/LEIS/L4320.htm>. Acesso em: 20 out. 2008.

. Lei Federal $n^{\circ}$ 5.172, de 25 de outubro de 1966. Disponível em: <http://www.planalto.gov.br/ccivil_03/LEIS/L5172.htm>. Acesso em: 20 out. 2008.

. Lei Federal $\mathrm{n}^{\mathrm{o}} 7.505$, de 2 de julho de 1986. Disponível em: $<$ http://200.181.15.9/CCIVIL_03/LEIS/L7505.htm>. Acesso em: 12 abr. 2010.

. Lei Federal $\mathrm{n}^{\mathbf{o}} 8.313 / 1991$, de 23 de dezembro de 1991. Disponível em: <http://www.planalto.gov.br/ccivil_03/leis/L8313cons.htm>. Acesso em: 20 out. 2008.

. Lei Federal no 8.429, de 2 de junho de 1992. Disponível em: <http://www.planalto.gov.br/ccivil_03/Leis/L8429.htm>. Acesso em: 20 out. 2008. 
Lei Federal $n^{\circ}$ 9.096, de 19 de setembro de 1995. Disponível em: <http://www.planalto.gov.br/CCIVIL/LEIS/L9096.htm >. Acesso em: 20 out. 2008.

. Lei Federal $n^{\circ} 9.424$, de 24 de dezembro de 1996. Disponível em: <http://www.planalto.gov.br/ccivil_03/Leis/L9424.htm>. Acesso em: 12 abr. 2010.

. Lei Federal $n^{\circ} 9.438$, de 26 de fevereiro de 1997. Disponível em: <http://www.planalto.gov.br/ccivil_03/Leis/L9438.htm>. Acesso em: 12 abr. 2010.

. Lei Federal no 9.503, de 23 de setembro de 1997. Disponível em: <http://www.planalto.gov.br/ccivil_03/Leis/L9503.htm>. Acesso em: 12 abr. 2010.

. Lei Federal $n^{\circ}$ 9.998, de 17 de agosto de 2000. Disponível em:

$<$ http://www.mc.gov.br/telecomunicacoes/fust/legislacao-1/leis/lei-no-9.998-de-17-deagosto-de-2000>. Acesso em: 20 out. 2008.

- Medida Provisória n 2.228-1, de 6 de setembro de 2001. Disponível em: <http://www.planalto.gov.br/ccivil_03/MPV/2228-1.htm>. Acesso em: 20 out. 2008.

. Medida Provisória $\mathrm{n}^{\mathrm{o}}$ 452, de 26 de dezembro de 2008.

$\begin{array}{lll}\text { Disponível em: } & <\underline{\mathrm{http}: / / \mathrm{ww}} \\ \text { 2010/2008/Mpv/452.htm>. Acesso em: } 10 \text { abr. } 2010 .\end{array}$

. Mensagem de Veto $\mathrm{n}^{\circ} 627$, de 4 de maio de 2000. Disponível

em: <http://www.planalto.gov.br/ccivil_03/Leis/Mensagem_Veto/2000/Vep101-00.htm>. Acesso em: 12 abr. 2010.

Parecer da Comissão de Constituição, Justiça e Cidadania, do Relator Senador Jefferson Peres, a Proposta do Senado Federal de Emenda à Constituição $\mathrm{n}^{\circ} \quad 96 . \quad$ Disponível em: $<$ http://www.senado.gov.br/sf/atividade/Materia/getPDF.asp?t=22915 > . Acesso em $22 \mathrm{dez}$. 2009

. Parecer da Comissão de Constituição, Justiça e Cidadania, do Relator Senador Jefferson Peres, sobre a Proposta de Emenda à Constituição (PEC) nº 96, de 2003. Disponível em: $<$ http://www.senado.gov.br/sf/atividade/Materia/getPDF.asp?t=22915>. Acesso em: 22 dez. 2009.

Parecer $\mathrm{n}^{\mathrm{o}}$ 1.033, de 2005 da Comissão de Finanças e Orçamento sobre o Projeto de Lei $\mathrm{n}^{\mathrm{o}} 224$, de 2005, que dispõe sobre as diretrizes orçamentárias do Estado de São Paulo, para o exercício de 2006 - Voto do Relator Dep. Edmir Chedid. Disponível em: <http://www.al.sp.gov.br/web/portal/ldo/conclusao.pdf $>$. Acesso em: 28 jan. 2009.

Parecer $n^{\circ} 1.033$, de 2005, da Comissão de Finanças e Orçamento sobre o Projeto de Lei $\mathrm{n}^{\mathrm{o}} 224$, de 2005, que dispõe sobre as Diretrizes Orçamentárias do Estado de São Paulo, para o exercício de 2006 - Voto em separado do Relator Dep. Roberto Engler. Disponível em: < http://www.al.sp.gov.br/web/portal/ldo/votosep.pdf >. Acesso em: 28 jan. 2009.

Parecer $n^{\circ} 1.756$, de 2009, da Comissão de Constituição, Justiça e Cidadania, da Relatora Senadora Lúcia Vânia, na Proposta do Senado Federal de Emenda à Constituição $\mathrm{n}^{\mathrm{o}}$ 96A. Disponível em: $<$ http://www.senado.gov.br/sf/atividade/Materia/getPDF.asp?t=67452>. Acesso em $22 \mathrm{dez}$. 2009.

Parecer n ${ }^{\circ} 1.756$, de 2009, da Comissão de Constituição, Justiça e Cidadania, Relatora Senadora Lúcia Vânia, sobre a Proposta do Senado Federal de Emenda à Constituição $\mathrm{n}^{\mathrm{o}}$ 96 ${ }^{\mathrm{a}}$ Disponível em: $<$ http://www.senado.gov.br/sf/atividade/Materia/getPDF.asp?t=67452>. Acesso em: 22 dez. 2009. 
Parecer $n^{\circ} 1033 / 2005$, da Comissão de Finanças e Orçamento sobre o Projeto de Lei $\mathrm{n}^{\circ}$ 224, de 2005, que dispõe sobre as Diretrizes Orçamentárias do Estado de São Paulo, para o exercício de 2006. Disponível em: <http://www.al.sp.gov.br/web/portal/ldo/texto.pdf $>$. Acesso em: 28 jan. 2009.

- Parecer $\mathrm{n}^{\mathrm{o}}$ 3472, de 2005, da Comissão de Finanças e Orçamento da Assembleia Legislativa, sobre o Projeto de Lei $\mathrm{n}^{\circ} 700$, de 2005, do Estado de São Paulo. Disponível em: $<\underline{\text { http://webspl1.al.sp.gov.br/internet/download?poFileIfs=6922426\&/Par3472>. Acesso }}$ em: 28 jan. 2009.

Projeto de Lei Complementar Federal no 494, de 2009. Disponível em: <http://www.camara.gov.br/sileg/integras/669902.pdf>. Acesso em: 9 set. 2009.

. Projeto de Lei Federal $\mathrm{n}^{\circ}$ 2.546, de 2003. Disponível em: <http://www.camara.gov.br/sileg/integras/182910.pdf > . Acesso em: 20 out. 2008.

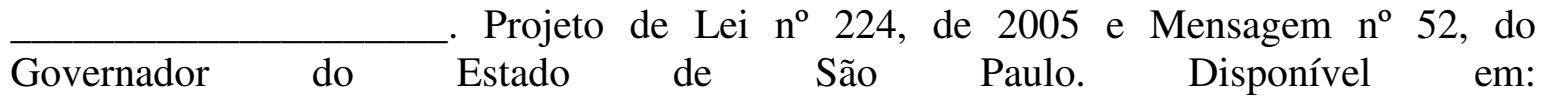
$<$ http://webspl1.al.sp.gov.br/internet/download?poFileIfs=5279392\&/ldo2006.pdf $>$.

Acesso em: 28 jan. 2009.

Projeto de Lei $\mathrm{n}^{\mathrm{o}}$ 463, de 2006, da Assembleia do Estado de São Paulo. Disponível em: <http://www.al.sp.gov.br/ >. Acesso em: 20 out. 2008.

Projeto de Lei $\mathrm{n}^{\circ}$ 655, de 2008, da Assembleia Legislativa do Estado de São Paulo. Disponível em: <http://www.al.sp.gov.br/>. Acesso em: $20 \mathrm{dez}$. 2008.

$\begin{array}{lllll}\text { Projeto de Lei } \mathrm{n}^{\circ} & 700 \text {, de } 12 \text { de setembro de 2005, do } \\ \text { Governador do Estado de São Paulo Disponível em: }\end{array}$ http://webspl1.al.sp.gov.br/internet/download?poFileIfs=6495838\&/Prop_Orca_2006.pdf" >. Acesso em: 28 jan. 2009.

. Proposta do Senado Federal de Emenda à Constituição n ${ }^{\circ}$ 96, de 2003. Disponível em: $<$ http://www.senado.gov.br/sf/atividade/Materia/getPDF.asp?t=38576>. Acesso em: 19 abr. 2010.

Resolução do Senado Federal $n^{\circ}$ 48, de 2007. Disponível em: $<$ http://www6.senado.gov.br/legislacao/ListaPublicacoes.action?id=256626 $>$. Acesso em: 13 abr. 2010.

76 Veto Parcial ao Projeto de Lei no 224 de 2005 e Mensagem $<$ http://webspl1.al.sp.gov.br/internet/download.do?poFileIfs=5904817\&/mensagem 076.doc >. Acesso em: 28 jan. 2009.

BulgáriA. КОНСТИТУЦИЯ НА РЕПУБЛИКА БъЛГАРИЯ. Constituição da República da Bulgária de 1991. Disponível em: <http://www.parliament.bg/?page=const\&lng=en>. Acesso em: 20 out. 2008.

CABo Verde. Constituição da República do Cabo Verde. Lei Constitucional n. ${ }^{\circ}$ 1/V/99 de 23 de Novembro. Disponível em: <http://www.icrc.org/ihlnat.nsf/162d151af444ded44125673e00508141/1437105f604ce363c1257082003ea54a/\$FI LE/Constitution\%20Cape\%20Verde\%20-\%20POR.pdf>. Acesso em: 23 out. 2008. 
ChILE. Decreto 100, de 22 de sep. 2005: Fija el Texto Refundido, Coordinado y Sistematizado de la Constitución Política de la República de Chile de 1980. Disponível em: $<$ http://www.leychile.cl/Navegar?idNorma=242302>. Acesso em: 16 out. 2008.

ColômBia. Constitución Política de la República de Colombia de 1991. Disponível em: < http://www.alcaldiabogota.gov.co/sisjur/normas/Norma1.jsp?i=4125>. Acesso em: 7 abr. 2010.

COREIA DO Sul. Constituição da Coreia do Sul. Disponível em: $<$ http://english.ccourt.go.kr>. Acesso em: 23 out. 2008.

DinAmarCA. Danmarks Riges Grundlov (Ato Constitucional da Dinamarca de 1953). Disponível em: <http://www.euoplysningen.dk/upload/application/pdf/0172b719/Constitution\%20of\%20Denmark.pdf>.

Acesso em: 7 abr. 2010.

El Salvador. Constitución de la República de El Salvador. Disponível em: $<$ http://www.asamblea.gob.sv/Constitucion/ConstitucionVigente1983.aspx >. Acesso em: 7 abr. 2010.

EQUADOR. Constitución Política del Ecuador de 2008. Disponível em: $<$ http://www.tribunalconstitucional.gov.ec/documentos/449_20081020.pdf $>$. Acesso em: 10 abr. 2010.

ESPANHA. Constitución Española de 1978. Disponível em: $<$ http://constitucion.rediris.es/legis/1978/ce1978.pdf $>$. Acesso em: 20 out. 2008.

. Ley 47/2003, de 26 de noviembre, General Presupuestaria. Disponível em: <http://noticias.juridicas.com/base_datos/Fiscal/147-2003.html>. Acesso em: 28.jan. 2009.

Estados Unidos DA AMÉRICA. Página virtual da Social Security Administration. Disponível em: <http://www.ssa.gov/>. Acesso em: 8 abr. 2010.

FILIPINAS. The 1987 Constitution of the Republic of the Philippines. Disponível em: $<$ http://www.architectureboard.ph/1\%20LAWS\%20(\&Regns)ON\%20ARCH3/1987Constit ution.pdf>. Acesso em: 7 abr. 2010.

FRANÇA. Loi organique relative aux lois de finances. Disponível em: $<$ http://www.minefi.gouv.fr/lolf/downloads/lolf_consolidee.pdf $>$. Acesso em: 20 out. 2008.

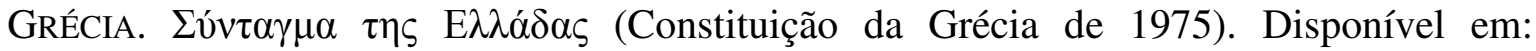
<http://www.ministryofjustice.gr/eu2003/constitution.pdf >. Acesso em: 7 abr. 2010.

Guandalini, Guiliano. O fundo da discórdia. Revista Veja, São Paulo, 7 jan. 2009, p. 4042.

Guatemala. Constitución Política de la República de Guatemala de 1985. Disponível em: <http://www.congreso.gob.gt/Pdf/Normativa/Constitucion.PDF>. Acesso em: 7 abr. 2010. 
HolandA. Grondwet voor het Koninkrijk der Nederlanden 2002 (Constituição do Reino dos Países Baixo de 2002). Disponível em: $<$ http://www.minbzk.nl/contents/pages/6156/grondwet_UK_6-02.pdf $>$. Acesso em: 7 abr. 2010 .

HungRIA. A Magyar Köztársaság Alkotmánya (Constituição da República da Hungria (Ato XX de 1949)). Disponível em: <http://www.mkab.hu/index.php?id=constitution>. Acesso em: 7 abr. 2010.

ITÁLIA. La Costituzione della Repubblica Italiana - 1947. Disponível em: $<$ http://www.quirinale.it/costituzione/costituzione.htm>. Acesso em: 20 out. 2008.

Legge 5 agosto 1978, n. 468. Disponível em: $<$ http://www.italgiure.giustizia.it/nir/lexs/1978/lexs_262368.html $>$. Acesso em: 7 abr. 2010 .

. Regio Decreto 18 Novembre 1923, n. 2440. Disponível em: <http://www.italgiure.giustizia.it/nir/lexs/1923/lexs_59398.html>. Acesso em: 7 abr. 2010.

Machado, Ana Paula. Entrevista com Patrick Jones: "EUA têm muito a aprender sobre concessão no Brasil”. Brasil Econômico. 20 nov. 2009, p. 24-25.

MÉXICO. Constitución Política de los Estados Unidos Mexicanos de 1917. Disponível em: $<$ http://www.cddhcu.gob.mx/LeyesBiblio/pdf/1.pdf>. Acesso em: 24 out. 2008.

NiCARÁguA. Constitución Política de Nicarágua de 1987 (con reformas incorporadas). Disponível em: <http://www.bcn.gob.ni/banco/legislacion/constitucion.pdf>. Acesso em: 7 abr. 2010.

PAnAmÁ. Constitución Política de la República de Panamá de 1972. Disponível em: $<$ http://www.asamblea.gob.pa/asamblea/constitucion/index9.htm\#cap2 $>$. Acesso em: 20 out. 2008.

PARAguAi. Constitución de la República de Paraguay de 1992. Disponível em: $<$ http://www.tsje.gov.py/constitucion-nacional.php >. Acesso em: 7 abr. 2010.

Peru. Constitución Política del Peru de 1993. Disponível em: <http://www.tc.gob.pe/legconperu/constitucion.html >. Acesso em: 20 out. 2008.

Portugal. Acórdão $\mathrm{n}^{\mathrm{o}} 452 / 87$ do Tribunal Constitucional. Disponível em: $<$ http://dre.pt/cgi/dr1s.exe?t=d\&cap=1$208 \&$ doc $=19880002 \% 20 \& v 02=\& v 01=2 \& v 03=1975-01-01 \& v 04=2008-07-$ $09 \& \mathrm{v} 05=\& \mathrm{v} 06=\& \mathrm{v} 07=\& \mathrm{v} 08=\& \mathrm{v} 09=\& \mathrm{v} 10=\& \mathrm{v} 11=\mathrm{Ac} \% \mathrm{~F} 3 \mathrm{rd} \% \mathrm{E} 3 \mathrm{o} \& \mathrm{v} 12=\& \mathrm{v} 13=$ Tribunal \%20Constitucional \&v14=\&v15=\&sort=0\&submit=Pesquisar \&d=2008-0709\&maxDate=2008-07-09\&minDate=1960-01-01>. Acesso em: 2 out. 2008. . Constituição da República Portuguesa de 2005. Disponível em: $<$ http://www.cne.pt/dl/crp_pt_2005_integral.pdf>. Acesso em: 2 out. 2008. . Lei de Enquadramento Orçamental no 91/2001. Disponível em: $<$ http://www.dgo.pt/legis/EnquadramentoOrcamental/Lei_enquad_orcamento.html $>$. Acesso em: 2 out. 2008. 
RePÚBliCA CHECA. Ústava České republiky. Constituição da República Checa de 1992. Disponível em: <http://www.hrad.cz/en/czech-republic/constitution-of-the-cr.shtml $>$. Acesso em: 7 abr. 2010.

RoMÊNIA. Constituţia României. (Constituição da Romênia de 1991). Disponível em: <http://www.cdep.ro/pls/dic/site.page?id=339\&idl=2>. Acesso em: 20 out. 2008.

RÚSSIA. Конституция Российской Федерации (Constituição da Federação Russa de 1993). Disponível em: <http://www.constitution.ru/en/10003000-01.htm>. Acesso em: 20 out. 2008.

SOVEREIGN WeAlth Institute. Página virtual. Disponível em: $<$ http://www.swfinstitute.org/swf.php>. Acesso em: 27 fev. 2009.

SuIÇA. Constitution fédérale de la Confédération suisse du 18 avril 1999 (Etat le 27 septembre 2009). Disponível em: <http://www.admin.ch/ch/f/rs/1/101.fr.pdf $>$. Acesso em: 7 abr. 2010.

UniÃo EUROPEIA. Regulamento (CE, Euratom) n 1605/2002 do Conselho, de 25 de Junho de 2002, que institui o Regulamento Financeiro aplicável ao orçamento geral das Comunidades Europeias. Disponível em: $<$ http://europa.eu/legislation_summaries/budget/134015_pt.htm>. Acesso em: 2 nov. 2008.

UNIVERSIDADE DE SÃO PAUlO. Perdas e ganhos: Veto de Alckmin ao aumento de recursos para a educação superior é mantido, mas governo propõe repasse equivalente a 9,67\% do ICMS para as universidades paulistas em 2006. Jornal da USP. 03 a 09 de outubro de 2005. ano XXI. n.739. Disponível em: $<$ http://www.usp.br/jorusp/arquivo/2005/jusp739/pag03.htm >. Acesso em: 28 jan. 2009.

URUGuaI. Constitución de la República Oriental del Uruguay de 1967. Disponível em: $<$ http://www.parlamento.gub.uy/constituciones/const004.htm\#art230>. Acesso em: 20 out. 2008. 